\title{
SHORTHORNS
}

\author{
IN CENTRAL AND \\ SOUTHERN SCOTLAND
}

\section{JAMES OAMERON}




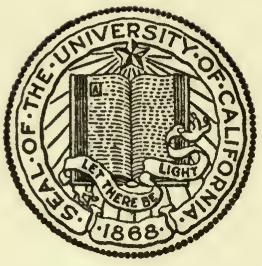

THE LIBRARY

OF

\section{THE UNIVERSITY}

OF CALIFORNIA

DAVIS 


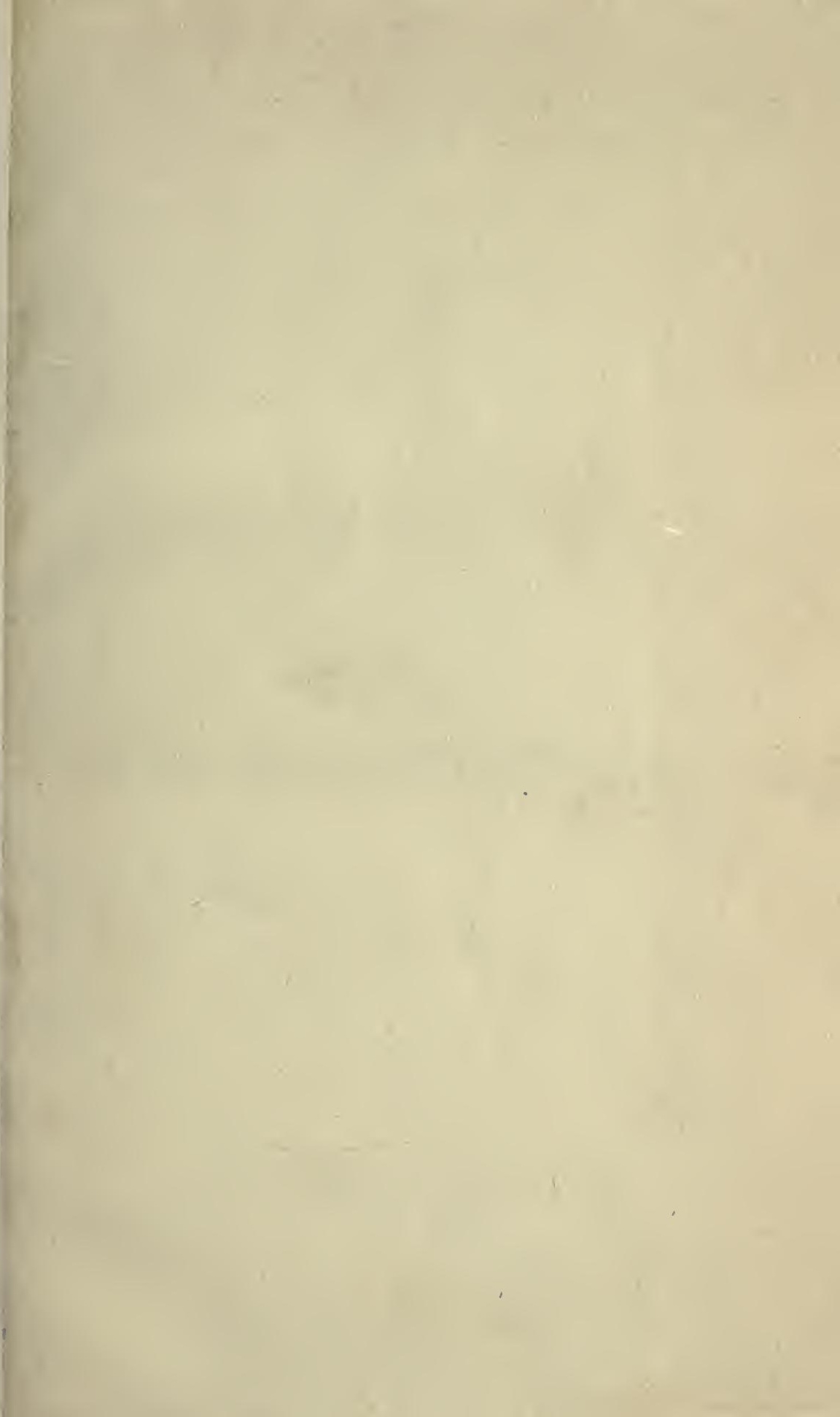




\section{Digitized by the Internet Archive in 2007 with funding from Microsoft Corporation}




\section{SHORTHORNS}

IN

CENTRAL AND SOUTHERN SCOTLAND 
7

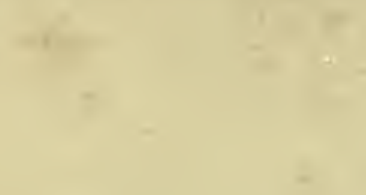

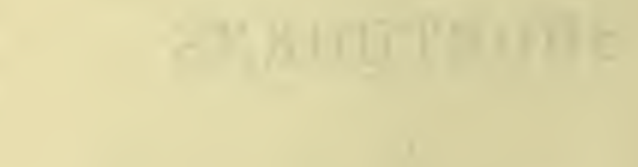



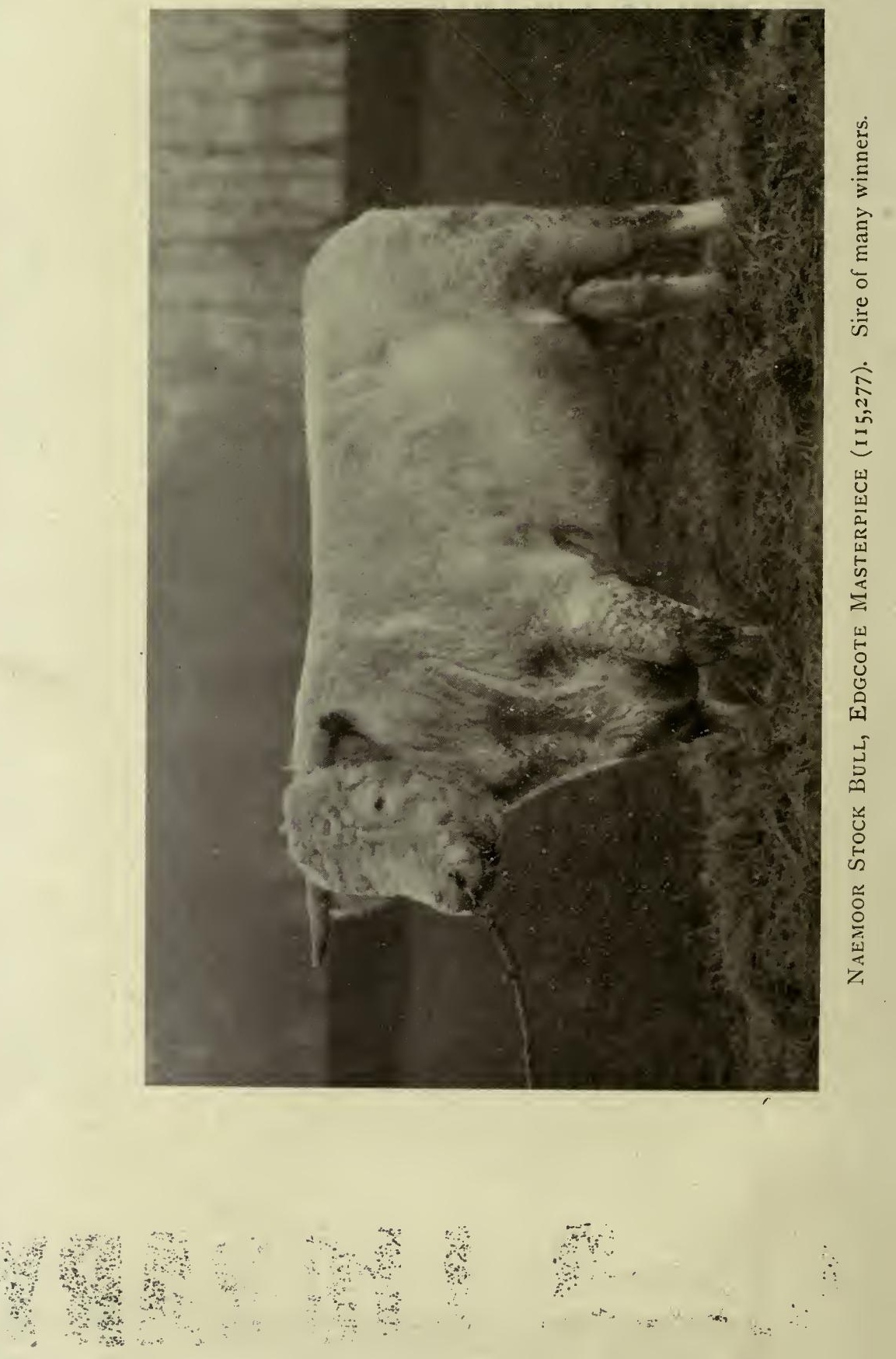


\section{SHORTHORNS}

IN

\section{CENTRAL AND SOUTHERN SCOTLAND}

BY

\section{JAMES CAMERON}

WITH AN INTRODUCTION BY

JOHN J. MOUBRAY

WILLIAM BLACKWOOD AND SONS EDINBURGH AND LONDON

MCM X X I

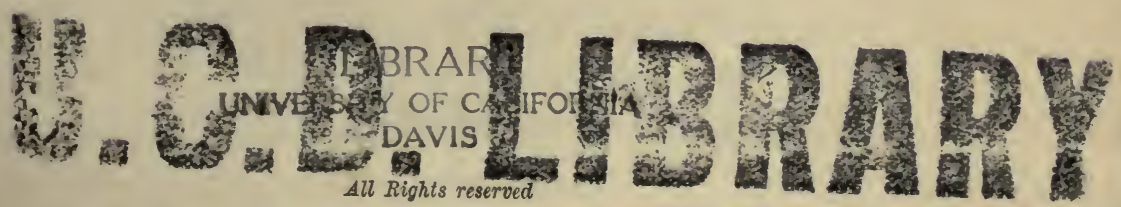





\section{CONTENTS.}

\section{HISTORICAL.}

\section{CHAPTER I.}

Earlier evidence on Shorthorns-Its mixed nature-Scope of present volume-Pioneers-Simson and Robertson-Sir John Sinclair, George Rennie, Robert Brown, Buchan Hepburn, and others on cattle breeds-Views of Culley and Curwen-Thomas Graham, Lord Lynedoch, as stock and crop improver-The Richmonds-Williamson of Lawers-His appearance and cbaracteristics-His herd and sale . . . .

CHAPTER II.

John Gardiner-His herd and sale-John H. Dickson-His families of cattle-Indebtedness to Keir-His sale-William and John M'Ewen-Their breeding stock-Sir Charles Dundas-Composition of his herd-How he looked at ring side-William Harris-Torenia and Robertson, Ballechin-Ballechin bullsDauntless and Newton Stone-Robertson's death-His saleAppearance and nature

\section{CHAPTER III.}

Colonel Munro--Mains of Murthly, Grandtully Vale, and MonessHis herd and sales-George Michie-Always "the Colonel"Viscount Strathallan's sale-Donald Fisher-Hotel and farm interests-Shorthorns at Cluny and Keithock-Sales-His last herd and sale-His many-sidedness and charm-Turnbull, Huntingtower-John Drummond, Blackruthven 
CHAPTER IV.

George, Lord Kinnaird-His varied interests-His ShorthornsThe Hunters and Patrick Kinnear-His lordship's criticsLumsden \& Mackenzie - Successful herd - John Drummond, Cultmalundie-Hugh Watson, Keillor-His Ury ShorthornsFriendships with Shorthorn breeders-Inches, Dalgairns, Hood, Stephens, and others-Rennie, Earl of Airlie, Arklay, James Swan-The Grangers-Taylor, Charles Lyall, David Hume .

\section{CHAPTER V.}

General Simson-His important work-Sam Wiley and SultanGeneral Watson-Bethune of Blebo-His Roses-Barclay of Keavil-Remarkable herd-Heir of Englishman-Sir John Gilmour-Noted stock-Dispersion sale .

\section{CHAPTER VI.}

Christie, Dairsie Mains-His noted cattle and sales-G.O.T. and James Bruce-John Hill, Langside-James Carnegie-Thomas Lawson-Meiklem Brothers, G. R. Fortune-Andrew MitchellA Booth herd-His sale-His personality-Duke of Montrose's herd - Simon Beattie and Rosedale - William Alexander, Loanside

\section{CHAPTER VII.}

Earl of Dunmore-Founding Bates herd-American transactionsHis great draft sale-Duke of Connaught-Earl's appearance and character-John Moubray - Great land improver-His honours and prizes-East Lothian notables-George Rennie, Brown, Carnegie-J. C. Curwen, M.P., Thomas Bates, Judge Hepburn-Correspondence-Lord Althorp and John Grey-John Rennie-James Tweedie-James Currie-James Douglas-His brilliant successes

\section{CHAPTER VIII.}

Ainslie of Costerton-Whittingehame herd-Its founding-The modern herd and dispersion-Dalkeith Park herd-Composition and early successes-The sale-James Deans-Joseph Lee-His composite herd-Successful sale-Mark S. Stewart-His herd and friendships-Dispersion sale . . . . . 


\section{CHAPTER IX.}

James Beattie, Newbie, and nephew-Founding of herd-Aylesby W's and Blooming Heathers-His sales-Visitors at NewbieThomas Marshall-Robertson of Ladykirk-His great workLord Polwarth-His appearance-Remarkable successes-Disappointing sale

\section{CHAPTER $\mathrm{X}$.}

The Bains' Legars-Brilliant showyard winnings-The sale-The Buchanans of Whitehouse - John Chrystal - Milne familyDryhope and Faldonside cousins-Their herds and fanciesMiss Milne of Otterburn-Sir William Scott, Bart.-George Torrance-Tweedside and Border Societies-Founding and work

-Border Union-Notable improvers

\section{HERD NOTICES.}

\begin{tabular}{|c|c|c|c|c|c|c|c|c|c|}
\hline \multirow{2}{*}{\multicolumn{2}{|c|}{ Abbey Mains }} & & & PAGE & & & \multicolumn{3}{|r|}{ PAGE } \\
\hline & & . & . & 95 & Dalcapon & - & . & . & 166 \\
\hline Ardargie & . & . & . & 99 & Dalmeny & . & - & . & 170 \\
\hline Arngask & . & . & - & 103 & Dargill . & . & . & . & 175 \\
\hline Auchnacree & . & - & . & . 108 & Darlingfield & . & . & . & 178 \\
\hline Balcarres & . & . & . & . 111 & Dolphingston & & 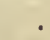 & . & 179 \\
\hline Baldowrie an & $\mathrm{d} R \mathrm{Ro}$ & semor & ant & . 114 & Doune Lodge & & . & . & 184 \\
\hline Ballechin & . & . & . & . 118 & Duchlage & • & $\cdot$ & . & 191 \\
\hline Balmanno & . & . & . & . 121 & Dunmore $\mathrm{Pa}$ & & & . & 195 \\
\hline Balmerino & . & . & . & . 123 & Eccles & : & . & - & 198 \\
\hline Balthayock & . & . & . & . 125 & Ednam Mains & Is an & & $\operatorname{ton} \mathrm{H}$ & 200 \\
\hline Bearcrofts & - & - & - & - 130 & Greenlees & - & . & . & 203 \\
\hline Boquhan & . & . & . & 132 & Harviestoun & • & - & . & 204 \\
\hline Butchercote & . & . & . & 137 & Hoprig Main & & . & . & 207 \\
\hline Cambus and & Glen & ochil & . & 140 & Kaimflat & . & . & . & 209 \\
\hline Carse of Gow & & . & . & 144 & Keir . & . & - & . & 211 \\
\hline Claymoddie a & and $C$ & Yruggl & eton & 147 & Kippenross a & and & $\mathrm{Kin}$ & urnie & 217 \\
\hline Cloichfoldich & . & . & . & 154 & Lawhill . & . & - & . & 218 \\
\hline Congalton & . & . & . & 155 & Lawton . & - & . & . & 221 \\
\hline Corston . & . & . & . & 158 & Longniddry & . & - & . & 225 \\
\hline Crieffvechter & . & . & . & 162 & Manderston & . & . & . & 228 \\
\hline
\end{tabular}


Herd Notices-continued.

\begin{tabular}{|c|c|c|c|c|c|c|c|}
\hline & & & PAGE & & & & \\
\hline Manuel House & 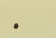 & & 230 & Redgorton & . & . & 270 \\
\hline Masterton & . & & 234 & Saltoun . & & . & 276 \\
\hline Millhills & & & 236 & Softlaw East & Mains & & 280 \\
\hline Milton of Lun & & & 242 & Stevenson & . & & 281 \\
\hline Moness . & . & . & 243 & Strowan & . & & 285 \\
\hline Naemoor & . & & 247 & Swinnie . & . & . & 290 \\
\hline Nether Kinne & & & 254 & Terrona . & . & . & 292 \\
\hline Newton of Str & thro & . & 257 & The Grange & . & . & 295 \\
\hline Orchard Farm & . & & 259 & Throsk . & & & 298 \\
\hline Polmaise & . & & 261 & Tulliallan & & & 301 \\
\hline Priestgill & & & 265 & Westside & . & . & 304 \\
\hline $\operatorname{achan}$. & & & 267 & Whittingeha & me Mains & & . 308 \\
\hline
\end{tabular}

Appendix

313

INDEX 


\section{ILLUSTRATIONS.}

NAEMOOR STOCK BULL, EDGOOTE MASTERPIECE $(115,277)$ Frontispiece (From Photo by Brown, Lanark.)

LADY RAMSDEN 3RD .

- Facing p. 126

(From Photo by Parsons.)

DALMENY GROUP

(From Photo by Brown, Lanark.)

DOLPHINGSTONE HEIFERS AT PRESTON GRANGE

(From Photo by Brown, Lanark.)

DOUNE LODGE GROUP .

(From Photo by Brown, Lanark.)

MILLHILLS STOCK BULL, CUPBEARER OF COLLYNIE

$(114,960)$ (AS A TWO-YEAR-OLD), AND SONS . " 240

NAEMOOR GROUP . . . . . .

(From Photo by Brown, Lanark.)

A REDGORTON GROUP.

" 272

(From Photo by Brown, Lanark.)

STROWAN CLARION $(110,333)$.

(From Photo by Parsons.) 



\section{AUTHOR'S NOTE.}

Mr first duty is to record my thanks to $\mathrm{Mr}$ J. J. Moubray, without whose encouragement and support this volume would not have been produced. My thanks are also due to Mr John Stirton, Mr Edward Cowie, and the general staff of the Highland and Agricultural Society for ever-courteous attention in connection with my examination of the Society's reference volumes. Many friends in various parts of the country have been very helpful. I have received assistance in various ways from $\mathrm{Mr} J$. Ernest Kerr; Mr R. Wylie Hill; Mr Wm. C. Hunter; Mr J. T. M'Laren; Mr James Rodger; Mr David Scott, Stirling; Mr John Phillips, Crieff; Mr R. K. Anderson, 'N.B. Agriculturist'; Mr J. Purves, Kelso; Mr R. D. Maxwell, Dumfries; Mr Alexander MacDougall, Annan; Mr James Beattie (grandson of the late Mr James Beattie, Newbie); Mr Hugh Mitchell, Pitlochry; Mr A. M. Douglas; Mr Thomas Bain, formerly of Legars; Mr A. C. 
Buchanan, and several others. I have been more than ordinarily indebted to $\mathrm{Mr}$ Hunter and $\mathrm{Mr}$ Douglas. For notes on the early life of Colonel Williamson and on the old Lawers herd, I have gone to a charming little volume by the late $\mathrm{Mr}$ John Stewart, Crieff.

Among histories, Sinclair's and Bell's have been of most use. Family papers have been of aid to some extent. To the foregoing $I$ have of course added my own recollections, and some garnering from occasional notes.

The Tulliallan and Boquhan herds, which are dealt with in the regular notices, now fall to be referred to as dispersed. Their sale averages are given in the Appendix, along with other relevant matters.

Glasgow, September 1920. 


\section{N T R 0 D UCT I 0 N.}

Two or three years ago it occurred to some members of the Scottish Central Shorthorn Association that a volume dealing with the past and present of the great breed of cattle in the counties between Perth and Forfar and the Border would prove interesting to breeders within that area, and useful to the general body of patrons in the homeland and beyond the seas. In these days there are demands for histories which deal with moderate-sized sections of the country. The underlying feeling is that a relatively compact history, whose scope is the country as a whole, must of necessity avoid excess of details. Emphasis must be laid on the larger events, and very many of the minor and still important movements must be either crowded in or crowded out. In practice it is usually found that much of a minor order has to be omitted in those histories which deal with Britain or the United Kingdom.

In the case now before us-a history of Shorthorns in Central and Southern Scotland-the selection of a 
writer had to come under consideration at the outset, and at an early stage those who were most interested fixed upon Mr James Cameron as the man most generally fitted for the task, on account of his long and varied experience of the breed and its patrons and his practice as a writer. Mr Cameron took to his duties most enthusiastically. In the volume there are no suggestions of the dry-as-dust. The writer is not even occasionally under the thrall of details. All through there is a sense of movement, and the reader is never conscious of being stranded in a dull period. Here we have very human glimpses and penand-ink portraits of Lord Lynedoch, Judge Hepburn, John Moubray, Alexander Geekie, Colonel Williamson, Lord Dunmore, Major Dundas, James Douglas, Donald Fisher, James Beattie, Alexander Robertson, Sir James Sivewright, Colonel Munro, Lord Polwarth (until recently with us), Wm. Bain, and others in the Shorthorn brotherhood. The personality of the men and what they did for the breed are rapidly estimated. These pages record a good deal that was in great danger of passing into oblivion.

Although the volume is nominally concerned with Central and Southern Scotland, its numerous side references render it interesting to the general reader. For another matter, the outsider has in the pages on existing herds many sketches of Scottish varieties of scenery, indications of soil characteristics, and touches 
which reveal the conditions under which Shorthorns are bred and reared in the different localities. The happily descriptive is unobtrusively blended with the main subject-matter. In studying this volume the enthusiastic breeder or admirer of pedigreed stock feels that he is in the company of the writer at homesteads, in the fields, by beautiful rivers and tumbling streams. And still the theme of themes is "The Shorthorn!"

JOHN J. MOUBRAY,

Chairman, Scottish Central Shorthorn Association.

Naemoor, Rumbling Bridge. 



\section{SHORTHORNS IN CENTRAL AND SOUTHERN SCOTLAND.}

\section{H I S T O R I C A L.}

\section{CHAPTER I.}

Earlier evidence on Shorthorns-Its mixed nature-Scope of present volume-Pioneers-Simson and Robertson-Sir John Sinclair, George Rennie, Robert Brown, Buchan Hepburn, and others on cattle breeds -Views of Culley and Curwen-Thomas Graham, Lord Lynedoch, as stock and crop improver-The Richmonds-Williamson of Lawers - His appearance and characteristics-His herd and sale.

He who fares forth mainly on the byways in quest of knowledge relating to the introduction of a new breed into many counties during a period extending from 100 to 130 years ago, must be prepared for some half-truths and for statements which fall short of the modern ideal in definiteness. A reason for this is to be found at the surface. In many cases the writers of the old reports on agriculture and stock-breeding in the various divisions of the country were merely men of general knowledge. Some of them were experts in meteorology, others were ahead of their time in sociological matters, and a few had more than the average grasp of the principles and practice of arable farming. 
A proportion of the farmer-writers might be classed as excellent men in accuracy and range of knowledge, but a number did not have more than the amateur's furnishing in regard to the breeding and feeding of farm stock. The quite fair presumption is that most of the writers acted with the utmost conscientiousness as local historians. With their work we must be content.

The writer's remit is of modest scope. It confines him to the past and present of the Shorthorn breed of cattle in Central and Southern Scotland. Still, within those boundaries a large amount of interesting historic material is available. It is a debateable point as to who led the way in introducing Shorthorns to Scottish homesteads and pastures. Some claim that General Simson of Pitcorthie, Fifeshire, took Shorthorns north into his county between 1780 and 1789 . His first authentically recorded purchases are connected with 1789 , and he is consequently on a pioneering equality at the least with William Robertson of Ladykirk, who laid the foundations of his famous herd in that year. The surprising matter to some modern students is that the work of those two remarkable men should have been so little known even when last century was a decade on its course.

In his 'Systems of Husbandry adopted in the more Improved Districts of Scotland' (1812), Sir John Sinclair refers to breeds "admirably calculated for fattening," and larger than the Kylo. The Galloway, Fife, Angus, and Buchan cattle are his choice. He compliments George Rennie of Phantassie on his "statement 
of the produce, rent, and expense of cultivating a farm in East Lothian of 533 acres Scotch or 702 English acres." In his 'Treatise on Rural Affairs' (1811), Robert Brown, farmer, East Lothian, a most enlightened man, refers to the Shorthorned, the Longhorned or Lancashire, the Galloway or Polled, and the Kylo breeds. The Shorthorned breed was found chiefly on the East Coast, and was named in some places the Dutch breed. It had been spoiled by certain men in Lincolnshire, he states, by importations of "bad sort of bulls from Holland," which rendered the cattle subject to " a lyer or black flesh." In other words, the flesh was naturally dark in colour and without any mottling or marbling, there being no fatty cells in it. Brown has words of commendation for the Fife cattle. Mr Buchan Hepburn of Smeaton, who dealt with East Lothian farming in 1794, records that Sir David Kinloch of Gilmerton was the only man in the county who bred a few heavy cattle of the Dutch or Holderness breed. Robert Kerr, farmer, Ayton, is interesting in his 'General View of the County of Berwick' (1809). He states that the cattle in the county were "much mixed by crossing," and difficult to describe. "Upon the whole," he notes, "they are shorthorned, and have been much improved by the Teeswater breed, which is the kind chiefly admired in this district." Robert Somerville, surgeon, Haddington, writing on farming affairs in his county (1805), says of the cattle, "The kind most generally prevalent is a cross from the Dutch or Holderness breed." That cross had supplanted a 
smaller breed, "black or dark brown, and with a rough strong coat." James Trotter, writing on West Lothian (1811), states that some proprietors had tried the Leicester' breed of cattle and the best Annandale, "which last seems to be near the same as the best Galloway." The Highland breed had been found the best for beef, and Highland bulls had been used for crossing. The Fife breed was the favourite for the dairy. George Robertson, farmer, Granton (1793), records, "There is no breed peculiar to the county, the kind consisting of almost every kind in Britain." Mr Wight, however (1778), had noted that the Duke of Buccleuch and Lord Adam Gordon had been doing well with Holderness crosses.

In his Agricultural Report on Forfarshire (1813), the Rev. James Headrick, minister of Dunnichen, says of the cattle in the county, "A great proportion of the stock are humlies (polls). A few individuals have the Shorthorned Teeswater breed." On Kinross and Clackmannan (1814) the Rev. Patrick Graham writes, "There is no breed of cattle peculiar to the counties." The smaller crosses were with the Highland, and the larger with the Fife breed. The Rev. James Robertson, D.D., the virile minister of Callander, is frank, if slightly ambiguous, in his Agricultural Report on Perthshire (1813). "Cows in general are of a bad breed," inferior to the North Argyll. The Angus and Fife breeds prevailed about Perth and Bridge of Earn. There were some good Galloways at Dunira and Lawers, and General Graham of Balgowan had some Devons. The Earl of Mans- 
field had a dairy of the "Lancashire breed." The "Argyleshire breed" was to be found in Rannoch, Glenlyon, Strathfillan, Glenlochay, and on the higher grounds in general. Dr Singer (1812) had a very poor opinion of the cattle stocks of Central Dumfries. From 1740 to 1750 , and later, the cattle were mostly horned, and worse than the Galloway "in figure and disposition to feed, and equally below the Teviotdale in size." He does not state what the Teviotdale breed was like. On Roxburgh and Selkirk the Rev. Robert Douglas, D.D., Galashiels, writing in 1798, states, "If ever there was a breed of black cattle peculiar to this county (Roxburgh) it cannot now be distinguished." The stock were very mixed. Between 1820 and 1830 the "Roxburgh" breed began to be much spoken of, even as far north as the Lothians. It was a Shorthorn-Highland cross of an excellent general-purpose order.

In regard to Selkirk, Dr Douglas notes: "A bull of the Teeswater breed, and remarkably handsome, was brought down a few years ago by Sir John Riddell, Bart. The descendants of this bull are rising to great esteem." After commending the work of improvers, he concludes with, "It is to be hoped this spirit will spread." In the early part of last century Ayrshire cattle were most numerous on the low grounds of Stirlingshire. The Highland breed held the higherlying parts. Some Shorthorns were tried at that time in Central Ayrshire, and also in Renfrewshire.

The Shorthorn had sometimes to fight its way against considerable opposition during the last quarter 
of the eighteenth century. Still its patrons had great faith. Their general forecasts were of ultimate victory. In a note to the 1801 edition of his book, 'Observations on Live Stock,' first published in 1786, George Culley, for example, wrote: "I am glad to find my hopes have been well-founded. A very rapid improvement has taken place in the breeding of Shorthorn cattle, so that in a few years I have reason to think they will surpass their rivals, the Longhorns." By 1811 a broad-minded experimentalist like J. C. Curwen, M.P., of Workington Hall, had come to the conclusion that the Shorthorn was winning all along the line. At that time Thos. Bates was submitting the Shorthorn-Highland cross to repeated tests. Curwen was watchful, and his conclusion was, "I am strongly of opinion your cross will never rival the Shorthorned." Further on he noted, "I am satisfied we shall agree in the opinion that the Longhorned cattle are the worst breed. Many of my farmers are getting rid of them" (Bell's History).

So far as I know, the earliest patrons of the Shorthorn in West Perthshire were Mr Thomas Graham of Balgowan, M.P., afterwards Lord Lynedoch, the most brilliant of Wellington's Generals, and $\mathrm{Mr}$ John Ritchie, Cultmalundie, an enterprising tenant-farmer. As a young man Graham was intensely interested in agricultural experiments, and he never lost sight of the practical. Between 1785 and 1788 he applied to George Culley for a trainer in the art of turnip husbandry on the improved lines of drilling and singling instead of broadcasting, and Culley strongly re- 
commended George Richmond, his cleverest "mud student." Richmond, although under eighteen years of age, taught the Balgowan tenants how to cultivate the land and make the most of the turnip crop. He himself settled in Perthshire, and became a most distinguished agriculturist. The late Mr John Richmond, tenant of Dron, Moneydie, and other holdings, breeder of Border Leicester sheep, and inventor of a graindrying rack, a potato-digger, and other appliances, was a grandson of George Richmond. Lord Lynedoch is stated to have kept Shorthorns as early as between 1815 and 1820 , but I have been unable to discover the extent of his work in connection with the breed. He was one of the purchasers at General Simson's sale in 1818. Mr Samuel Richmond, son of $\mathrm{Mr}$ George Richmond, had a good herd of Shorthorns at Chapelpark in the thirties of last century, but I have no particulars in regard to the breeding of the cattle.

A strong personality in Perthshire Shorthorn, social, Volunteering, and sporting life was Colonel David Robertson Williamson of Lawers (1829-1913), a perfect exponent of that "grand" early Victorian manner of which scarcely a vestige is left! Splendidly athletic in build; spare, handsome, powerfully muscular, lithe in movement, he could work in and out of a company with the ease of an all-conquering yet supremely urbane General. The music of his voice, the light in his fine grey eyes, the glamour of his smile, formed a happy combination. On his hunting-horse or afoot his was a gallant figure. Yet he 
could be very distinctly nasty in his own magnificent manner, and, like Captain Barclay of Ury, he was an ugly customer with his fists, and had been a most enthusiastic patron of the old P.R. The Lawers herd was founded by Colonel Williamson's father in 1841, and Mr David Robertson Williamson, as he then was, succeeded to the property in 1852 . When fairly settled down as laird, he started to buy cattle from the Earl of Zetland, Sir Wm. Stirling-Maxwell, the Duke of Montrose, Mr James Douglas, Mr George R. Barclay, Mr Hugh Aylmer, Messrs Cruickshank, and others. Booth bulls were his fancy, and he had a special liking for the blood of the Dalkeith Knight Errant. His leading sires were Mario (16,505), Teithside $(17,082)$, Caractacus $(19,397)$, Ben Lawers $(19,304)$, Keir Butterfly 6th $(26,493)$, Baron Rosebery $(33,078)$, Demetrius (33,532), Young Vinedresser $(25,380)$, and Carlos $(39,553)$.

Prior to 1879 Colonel Williamson held the lead at 100 gs. for a young bull sold at Perth. This was with Prince of Atholl. In his time he won numerous county prizes, and with the yearling Master Tree he led at the Edinburgh Highland. The herd was sold on 25th October 1879, but, merits of the stock considered, prices were low. The Hon. George Waldegrave Leslie paid 41 gs., the top figure in cows, for Rosamund, a fine roan by Demetrius. Captain C. H. Dundas took Marchioness, by Prince Henry, out of a Keir Butterfly 6th dam, at 40 gs. Prince Henry was out of the Keir first prize Highland Society cow Henrietta, which was sold at 400 gs. for 
Minnesota. In heifers, Charlotte, by Merman, was taken out for Keir at 46 gs. A bull calf, Lawers Alexander, by Lollius Booth, drew 61 gs. from Mr Wood of Freeland, and the bull, Lawers Captain, bred by $\mathrm{Mr}$ Aylmer, was sold at 50 gs. to Sir David Baird. Those were the best prices. To the end of his days the Colonel took a great interest in Shorthorns, but his tastes held very much to the older types-the long, low, and swaggeringly-stylish. 


\section{CHAPTER II.}

John Gardiner-His herd and sale-John H. Dickson-His families of cattle-Indebtedness to Keir-His sale-William and John M'Ewen -Their breeding stock-Sir Charles Dundas-Composition of his herd-How he looked at ring side-William Harris-Torenia and Robertson, Ballechin-Ballechin bulls-Dauntless and Newton Stone -Robertson's death-His sale-Appearance and nature.

Is Perthshire farming and stock-breeding circles of sixty to eighty years ago Mr John Gardiner of Rottearns, Auchterarder, and tenant of Kinkell, was a man of note, because of his broad outlook and strength of character. He founded his Shorthorn herd with purchases from Warlaby, Towneley, Athelstaneford, Sittyton, and Keir. During the late fifties he gradually sold most of his cattle. He retired from farming in 1861, and died about eight years afterwards. At Mr Gardiner's sale on 22nd October 1861, the Sittyton-bred roan cow Aroma, by Matadore $(11,800)$, was taken at $50 \mathrm{gs}$. by Mr James M'Artney, Yetts of Muckart; Princess Mary, a roan also bred by the Messrs Cruickshank, and by The Baron $(13,833)$, was secured by Mr M'Artney at 60 gs.; Queen of Beauty 4 th, a roan by Prince le-Beau (13,512), made less money. She was out of the same dam as Lord Strathallan's Retribution, the Aberdeen Highland 
Show winner of 1858 . The heifers and calves met a fair sale. Mr Amos Cruickshank took Aroma 2nd, a roan, by The Baron $(13,833)$, at 45 gs., and the red heifer calf Mysie 11th, by Indispensable $(16,295)$, at $35 \mathrm{gs}$. $\mathrm{Mr}$ Wm. Dron took the red two-year-old Mysie 7 th, by Indispensable, at $23 \frac{1}{2}$ gs. Mysie 12 th, a roan yearling by Indispensable, was acquired by Mr Stirling of Kippendavie at $24 \frac{1}{2}$ gs. Mysie $3 \mathrm{rd}$, the dam of that heifer, had previously been sold to Sir Wm. Stirling-Maxwell, from whom Mr Gardiner had acquired the family.

Mr John H. Dickson, gentleman-farmer, lover of a well-bred Shorthorn, and sportsman, to whom a tramp over a grouse moor behind good working pointer dogs had special attractions, built up a fine herd during his lease of Cambushinnie, on the Cromlix estate. His principal families of cattle were the Groats and the Mysies from Keir, and what came to be known as the Matadores, from the Keirbred Mary, by Magenta $(20,253)$. Being on the friendliest of terms with Sir Wm. Stirling-Maxwell, $\mathrm{Mr}$ Dickson was very greatly indebted to Keir for the use of bulls. Mr Dickson, who was as well known to many as of Saughton Mains, died in 1877, and his herd was sold off on 4 th October of that year. Times were quiet for those who did not fall in with the Booth and Bates factions. For 84 head the sum realised was only $£ 1718,6$ s. 6 d. The averages were -32 cows, £23, 17s. 5d.; 25 heifers, £19, 4s. 2d.; 17 bull calves, $£ 20,18 \mathrm{~s} .2$ d. ; 9 heifer calves, $£ 10$, $3 \mathrm{~s}$. Among the buyers were $\mathrm{Mr}$ Currie, Halkerston; $\mathrm{Mr}$ 
Andw. Ralston, Glamis; Sir Wm. Stirling-Maxwell, who paid the top price of 45 gs. in cows for Butternut; Mr Wm. M'Ewen, Cambushinnie; Mr John Granger, Pitcur, who bought five heifers-a couple of Maggies, a Matadore, a Marchioness, and a Groat, the Matadore being the highest priced at $30 \mathrm{gs}$. The red-andwhite Gwynne bull, Prince of Schleswig $(35,158)$, went at butcher's price. The older cows at the sale were by Indispensable (16,295), Magenta $(20,253)$, Lord Strathearn (22,219), Strathallan $(37,539)$, and Duke of Glasgow $(33,649)$. Most of the female animals from three to five years old, and a large number of heifers, were by the famous Bywell $(33,261)$.

$\mathrm{Mr}$ Dickson was succeeded in the tenancy of Cambushinnie by the late $\mathrm{Mr} \mathrm{Wm}$. M'Ewen. At $\mathrm{Mr}$ Dickson's sale Mr M'Ewen bought two cows and two heifers. These were the white, Matilda (lot 4), by Albert, a son of Lord Strathearn $(22,219)$; Mayflower (lot 32$)$, also a white, by Bywell $(33,261)$; the yearling Lady May (lot 57), a white, by Bywell; and the heifer calf Little May (lot 75), a roan, by Schleswig $(35,158)$, out of Mayflower. Those animals bred well, and were all good milkers. Mr M'Ewen's principal selections afterwards were a Butterfly cow and heifer calf from Mr Balfour of Balbirnie, and the bull Flowerman, a white bred at Keir, and by the famous Fandango $(33,879)$. Flowerman led in his class at the Stirling Show of 1883 , and stood reserve to $\mathrm{Mr}$ Moubray's cup-winner. Mr M'Ewen died in 1883, and his son, the late Mr John M'Ewen, followed in the tenancy. To his father's Cambushinnie stock $\mathrm{Mr}$ 
John M'Ewen added three cows of the Beaufort Undine family, from the late Mr Peter M'Caull's sales at Knockhill, Bridge of Allan. His best-known bull was the Aylmer-bred roan Pole Star $(66,024)$, which he acquired from Mr Alexander Robertson, Ballechin. With Pole Star Mr M'Ewen won the cup at Stirling, and fourth prize at the Highland. The bull was then sold for exportation to the Argentine. $\mathrm{Mr} \mathrm{M} \cdot$ Ewen received some good prices at Perth during the eighties, but when times became dull he gradually sold off most of his Shorthorns.

For about nine years (1879-1888) the late Captain Charles H. Dundas, afterwards Sir Charles H. Dundas, Bart., had a good herd at Dunira. The foundation was laid with selections from Keir, Halkerston, and Lethenty. Booth, Bates, and Knightley blood were blended towards the finish. The dispersion sale, which was held on 28th September 1888, proved dull, although the exposer was a man of singular charm and universally esteemed. The best figure was 55 gs., paid by Mr Burt Marshall of Luncarty, for Luxury, a yearling heifer. For nearly a quarter of a century, down to about 1914, the Luncarty herd was kept going. Among the buyers were Lady Cathcart, the Earl of Camperdown, Mr F. W. Christie, Mr Alexander Robertson, Mr Carnegie of Aytounhill, and Messrs Lumsden \& MacKenzie. Perthshire men of the older school love to remember Sir Charles when he was the portly, ruddy-coloured Major Dundas of the closing decade of last century. He was a most characteristic figure- 
head at the Crieff Games and Cattle Shows. In his favourite after-lunch pose, leaning forward on his hazel crook, just at the edge of events, he was a quietly happy stalwart. The double-peaked cap, tawny moustache, briar pipe, shooting-jacket, kilt, plain sporran, and tanned knees, marked the Major. The briar kept going with easy assiduity, while true comradeship oozed from every pore of the strong man's being. At times he could be fine company for himself, but more generally he was in a deeply friendly trio or quartette- "Aye a gentleman" was the rural summing-up on him.

Some men are remembered through a form of accident. $\mathrm{Mr}$ William Harris, Tirinie, Aberfeldy, is one of those men. Mr Harris was a timber merchant and holder for a good many years of busy saw-mills at Blair-Atholl. A very enterprising man, of smart business turn, he had remunerative contracts with the Highland Railway in the early sixties; and it might have been better for him had he held away from farming. Anyhow, he took a lease of Tirinie about 1865, and sold off his small herd of Shorthorns in 1879 , before his outgoing. His females were descended from the cows Mignonette and Snowberry, which he had bought at the Inchbroom dispersion, Morayshire, in 1868, at 44 and 35 guineas respectively.

Torenia, a massive roan yearling, grand-daughter of Mignonette, was acquired by $\mathrm{Mr}$ Alexander Robertson, Ballechin, at Mr Harris's sale. She cost only 25 gs., but she proved one of the grandest 
breeders ever known in Central Scotland. From her Mr Robertson bred his beautiful Tulips, Cherrys, and Blossoms, which won numerous prizes, and gained high favour in North and South America. In a general way, apart from Ballechin, the descendants of Torenia came to be known by the older family name-the Carnations - whose foundation dam was Countess by Young Eryholme (1891). Torenia, which was by Mr Donald Fisher's Sir Charles $(39,113)$, had a highly distinguished bull - breeding daughter at Ballechin in Pansy Blossom, a shortlegged and singularly handsome dark-red roan by the Lawers-bred Loyalty $(49,996)$. In after years Mr Robertson added a representative of Mr Stephenson's old Blanche family, so well known later at Towneley Park and Keir. A Rosebud and an Emmeline from Mr Wm. Duthie; an Orange Blossom from Jackstown; a Lady Dorothy and a Graceful from the Messrs Law; a Clipper from Newton; and a Rachel from Uppermill, were the principal additions during the later history of the herd.

Famous bulls were used by Mr Robertson. Among these were the light roan Sittyton-bred Dauntless $(54,155)$; the Collynie Mutineer $(69,169)$, a Missie by Scottish Archer $(59,893)$; the Uppermill Airy Monarch $(65,067)$ by Sea King $(61,769)$; Newton Stone $(75,129)$ of Mr A. M. Gordon's breeding, and by the champion Corner Stone $(68,406)$, from a Star of Morning $(58,189)$ cow ; the Jackstown Victor Chief $(82,532)$ by Lord Lynedoch $(74,900)$; the Barrelwell Marquis $(84,061)$, one of the prettiest bulls of his 
time; and the noted Highland and Royal Show bull Avondale $(94,085)$, bred by Mr James M'William. Dauntless, whose sire was Feudal Chief $(51,251)$, was acquired from the late Mr Maxtone Graham as a three-year-old at the fall of 1889. He left a lot of uniformly high-class females at Ballechin. While in their prime his cows were admired for their noble heads, good scale, and milking properties. $\mathrm{Mr}$ Robertson sold the bull as a six-year-old to $\mathrm{Mr}$ Duthie, and promptly regretted the transaction. Dauntless passed his later years in the possession of Mr Thomas Horsfall, Yorkshire, and there his groups of young bulls proved remarkably successful for several seasons. His sire, Feudal Chief, was not a favourite with Mr Duthie, but Mr Cruickshank must have had more than a sneaking regard for the "Chief." In his old age Amos was discussing with "Collynie" the merits and pedigree of a certain bull, when the junior remarked, "I see he has got the cross of Feudal Chief." "Oh yes!" responded the senior, "and he is none the worse for that." Dauntless had somewhat plain, forward-staring horns, which he did not transmit. He had a beautifully-moulded frame on short legs, and always carried a thick, even, and mellow covering of flesh, his hook bones being perfectly hid. Even as an old bull he had a wealth of soft mossy hair. "Ballechin's" other special regret was in selling Newton Stone as a two-year-old for exportation to the Argentine, as that bull was to be a superb breeder. In the Argentine his success as a sire of male and female animals was unprecedented, 
and as a six-year-old he was sold for $£ 2620$. Victor Chief left thick-framed fleshy stock, but Mr Robertson blamed him for reducing the milk to some extent. In the Argentine the bull was sold for $£ 1650$. Marquis, which was sold at Buenos Ayres for $£ 2000$, left heifers with showy heads and neatly-turned bodies, but in some cases his colours were inclined to be slightly gaudy.

Mr Robertson died on 15th August 1909, after a long illness, which never quite daunted his brave nature, and his herd was dispersed on 9th October of the same year. The cattle were admirably shown by James Forsyth, who had been herdsman for fourteen years. For 80 head, which included 26 calves, the average was $£ 61,14 \mathrm{~s}, 3 \mathrm{~d}$, , a remarkably good result for the time.

Captain A. T. Gordon took the Newton-bred Clipper cow Claudia, by Corner Stone, at 150 gs., and her beautiful red heifer calf by the Collynie Golden Favourite $(98,760)$, at 180 gs. For Ballechin Roan Rose, a massive daughter of Victor Chief and dam of Jim Sidey $(99,230)$, Mr J. J. Moubray paid 270 gs., and her roan May-born bull calf by Golden Favourite went to Dunglass at 100 gs. Sir John Gilmour paid 100 gs. for a sweet Emmeline five-year-old by Marquis; Mr Matthew Marshall took Red Roseleaf, a half-sister to Mr Moubray's purchase, at $150 \mathrm{gs.}$; and Mr Ecroyd of Armathwaite, who greatly favoured the members of the Blanche family, had a lovely red four-year-old by Marquis at 280 gs. Mr Ecroyd also took a three-year-old, full sister to the 280 -gs. cow, at 180 gs.; while, opposed by Colonel Fenwick, he 
secured an exceedingly pretty yearling of the same line by Tom Bowling $(97,441)$, at 210 gs. For the handsome red Missie bull Golden Favourite $(98,960)$, the Duke of Portland's agent paid $210 \mathrm{gs}$, and $\mathrm{Mr}$ J. D. Fletcher went to 190 gs. for a very good-looking red yearling, son of the 280-gs. cow. Mr Charles E. Law had probably the best of the bull calves in a red by Golden Favourite, out of an Emmeline cow by Newton Stone.

When in his prime $\mathrm{Mr}$ Robertson was a finely built man. He had an expressive countenance, artistic tastes, and a charm all his own as a host, but at odd times in his later years he was prone to pass into the deeps of thinking, and so to lose temporarily the surface thread. 


\section{CHAPTER III.}

Colonel Munro-Mains of Murthly, Grandtully Vale, and Moness-His herd and sales-George Michie-Always "the Colonel"-Viscount Strathallan's sale-Donald Fisher-Hotel and farm interests-Shorthorns at Cluny and Keithock-Sales-His last herd and sale-His many-sidedness and charm-Turnbull, Huntingtower-John Drummond, Blackruthven.

ON the south side of the Tay valley, Colonel Charles Munro was an enthusiastic supporter of the Shorthorn cause for a long term of years. At Grandtully Vale Farm, between the noble Tay and the birchen braes leading to the heather, at breezy Mains of Murthly near Aberfeldy, and in later years at cosily set Moness, close by the roystering burn and the show spot of the little burgh, the Colonel bred fine cattle. He was a frequent prize-winner at the Perth spring exhibitions, a prominent winner at the summer events in the county, and he competed occasionally at the Highland.

He founded his herd in 1880 mainly with northeastern purchases of the best breeding, including the Secret, Violet, Crocus, Jenny Lind, and other good families, Clippers being added in 1898 at Mr Donald Fisher's sale. His best breeding bull during the earlier stages was the Dunglass-bred Chamberlain 
2nd $(65,237)$, the sire of the Highland Society firstprize yearling heifer Nessie. Twenty years later he had an exceptionally good stock bull in the Pirriesmill-bred Knight of Strathbogie $(81,405)$, which was discovered as a three-year-old on a south Perthshire farm, shifted to Mains of Murthly, and kept there for two seasons. Sold to an Irish breeder, he was exported to the Argentine when nearly six years old, and in the far-away country he changed ownership finally at $£ 500$. In 1899 Colonel Munro had a successful draft disposal at the Vale farm.

The lease of the picturesque but somewhat shingly riverside holding terminated in 1905, and on 29 th August of that year the Colonel sold his herd. The sale, which was held at Moness, resulted in an average of $£ 33,4$ s. 6 d. for 79 head, which included members of the Miss Ramsden, Broadhooks, Carnation, Mysie, Jenny Lind, and Balnakyle Maggie and Lady families. Mr Calder of Ardargie was one of the leading buyers, and among others who made purchases were Sir James Sivewright, Mr Wm. Duthie, Mr A. M. Gordon, and Mr Tong.

With six years of Mains of Murthly lease still to run, and with Moness as an annexe, the Colonel resolved to start a new herd on the most fashionable lines, but by 1914 he made up his mind to retire from farming. Moness was again his sale centre. The dispersion took place on 23rd April, and although most of the breeding stock had been born elsewhere, and were in comparatively thin condition, an excellent sale resulted, the average for 40 head being 
£81, 6s. 5d. The Hon. H. C. Lewis, afterwards Lord Merthyr, paid 370 gs. for the very good-looking red four-year-old Albert Princess Royal by Bapton Mischief $(97,946)$, and her roan heifer calf by Merry Victor passed to $\mathrm{Mr}$ Cazalet at 110 gs. Princess Royal 110th, a good-bodied red, rather plain in. horn, went to $\mathrm{Mr}$ Duncan Stewart at 160 gs., and her beautiful dark roan heifer calf by Merry Victor was secured by Mr Lewis at 170 gs. The Collyniebred white two-year-old Merry Victor (116,563), a handsome son of Merry Stamp, was turned out to Sir James Sivewright at $135 \mathrm{gs}$. The most famous bull ever owned by Colonel Munro was the MorganRichardson bred Massena $(99,562)$, by Moonlight $(75,110)$. For his breeder and the Colonel, that bull won about 30 first and champion prizes.

George Michie, one of the most faithful of herdsmen, had been in charge of the Grandtully Vale stock. A simple, shrewd, unspoiled original, he had the gift of stirring the wells of humour in all men with an endowment of that heaven-bestowed faculty, and the peculiar charm lay in his complete unawareness of his phase of genius. He loved to have at least one first-class show animal, preferably a "bul," to look at and talk to as he took a quiet draw at his pipe. Once at the Vale he laid down his gentlest approach to an ultimatum- "Cornel, I wid like to hae an exheebiteeve bul," - the inference being that if he did not get his animal he might possibly flit. But George had no intention of flitting.

Officers in the Volunteering and Territorial Forces 
have generally doffed their titles with their discarding of uniforms, but to the end Colonel Munro remained "the Colonel," and no north-going company from Central Scotland for the autumn Shorthorn sales of ten to thirty years ago was reckoned to be complete without him.

A prominent prize-winner during the fifties and sixties of last century was the fine Scottish gentleman, Viscount Strathallan. His select little herd of blended Booth and Bates blood was sold off at Stirling on 27 th August 1867, with fair results, the animals being shown in rather thin condition. For 28 head the average was $£ 27-21$ cows and heifers averaging $£ 40$. Violante, a well-known Towneleybred red ten-year-old by Valiant $(10,987)$, was taken for Keir at 91 gs.; Warlabina, a wide-ribbed sixyear-old roan by Hautboy $(18,034)$, fell to $\mathrm{Mr}$ Botcherby, Darlington, at 53 gs.; the better-known Rosa Bonheur, a roan five-year-old by Bridegroom $(17,441)$, passed to the Duke of Richmond at 74 gs.; her handsome two-year-old daughter, Rose of Strathallan, a roan by the Keir Allan $(21,172)$, went to $\mathrm{Mr}$ Currie of Halkerston at 86 gs. ; and Rosabel, a redand-white of the same age, and also by Allan, was secured for Keir.

But Mr Donald Fisher! One could never term him a person. He was a personality. The eldest son of the proprietor of the Dunkeld Royal Hotel, Mr Donald Fisher was intended for a commercial life. He served his apprenticeship in the Bank of Scotland, Dunkeld, and was for some time afterwards 
with the banking firm of Ransome, Bouverie, \& Co., London. On the death of his father he returned to his native burgh to assist in conducting the family business. About 1853 he took the Pitlochry Hotel, which he named "Fisher's," and enlarged from time to time. Even as a boy he had a love for farm life, and an eye for a Shorthorn. His brother John took the Bridge of Tilt Hotel, Blair-Atholl, in 1855, and another brother followed up in the late fifties by acquiring the Braemar Hotel. Those were coaching days, and Donald was master of ceremonies at the all-important corner of the triangle.

Shortly after settling at Pitlochry, $\mathrm{Mr}$ Donald Fisher rented the farm of Cluny from Mr Butter of Faskally, and in a year or two he began to lay the foundations of a Shorthorn herd. Sir Charles Knightley's herd was sampled in 1856 for a Cold Cream, and he drew otherwise on the Duke of Montrose, Mr James Douglas, and Mr Lowndes. On the Booth side his early choice was the Medora or Isabella. In sires his ideal at the outset was the Booth, and later a play between Warlaby or Killerby and Knightley. Cluny was an unsuitable farm for Shorthorns, and so, during the later fifties and early sixties, drafts of fine cattle were sent along to Bridge of Tilt, where their summering was mostly on the northern side of the road near the old Episcopal Church.

Still there was congestion, until Mr Fisher acquired a lease of the fine farm of Keithock, near CouparAngus. There he held a successful sale in October 
1874, his average for 42 head being $£ 86,9$ s. His Cold Creams were then in the ascendant. Duchess of Knightley went to $\mathrm{Mr}$ W. R. Davies at $280 \mathrm{gs}$.; Fawsley 5 th to $\mathrm{Mr} \mathrm{A}$. H. Longman at 215 gs. ; and other ten made 100 gs. and over. The Earl of Derby, Lord Kinnaird, Sir Wm. Stirling-Maxwell, Bart., and Mr Sylvester Campbell, were among the purchasers. On 24th April 1879 he sold off his Keithock stock, as his lease was almost terminated. It was a dull disposal. For 49 head his average was only $£ 35,12$ s. The Aylesby Waterloo cow, West Hope, which cost 220 gs. in 1875 , passed out of the ring at 61 gs. to Sir Wm. Scott of Ancrum. Ringdove, which was acquired at the Peepy sale of 1875 at 160 gs., also found her limit at 61 gs., her buyer being Mr Mollison for Dochfour. Mr Wm. Tait, Mr Maxtone Graham, Mr Chandos Pole-Gell, Mr John Granger, Pitcur, Mr John Cran, Kirkton, and others, had easy bargains. Among his favourite bulls were Scottish Chief $(22,850)$, The Chieftain $(20,942)$, Good Hope $(31,274)$, Fawsley Prince $(31,150)$, Brother Windsor $(25,690)$, and Valentine Vox. The last named was passed to Mr Marr, Cairnbrogie, at the 1874 sale for $63 \mathrm{gss}$.

For a few years during the eighties $\mathrm{Mr}$ Fisher had no representatives of his beloved breed, but shortly after 1890 he took the pretty little farm of Croftinloan, on the south-facing braes near Pitlochry, and started with all his old ardour to form a herd. A Clipper from Collynie; a Missie, a Maude, and a Rachel from Uppermill, were soon agreeably associ- 
ating with a Booth Mantalini and a Mistress Mary; a descendant of the champion Rosario from Arabella, a Cold Cream from Windsor, a Certainty from Brawith, and a fine representative from Inglewood.

It was far on in the afternoon of life for the brave little man, but with the Collynie-bred Christmas Present $(63,793)$ from Bapton Manor he began to bring his composite materials under subjection. The old red Cruickshank Captain of the Guard $(58,596)$ was the notable stock bull a few years afterwards. $\mathrm{He}$ also came from Bapton Manor. By $1898 \mathrm{Mr}$ Fisher began to feel the burden of years. He resolved to sell off. "What would you do if you had your life to begin again and now?" the writer asked him at Croftinloan on a glorious day shortly before the sale. The Tummel was singing dreamily on its course to the Tay, there was a shimmering tremble on the heather, and the woods of Dunkeld and Atholl were almost beginning to play with the harmonies of autumn. "I would take the finest of the Knightley females, and I would put to them the best Quaker (Cruickshank) bull that money could buy," said the veteran. His sale in perfect sunshine on the second last day of August was a success. Mr John Thornton was in his very brightest mood on the rostrum, and at the finish Mr Fisher made one of those deftlyphrased little speeches of which he was such a master. Fifty head averaged $£ 45,15 \mathrm{~s} .2 \mathrm{~d}$., the average for a fine lot of two-year-old heifers being $£ 60,2$ s. 9d. The agent for the Prince of Wales paid the top price of $140 \mathrm{gs}$. for Cora, a handsome two-year-old 
Clipper heifer. Mr A. M. Gordon and Colonel Munro had also representatives of the Clipper family.

In the Colonel's case he was humorously run in for twin Clipper heifer calves just beginning to fall into a staggering walk. They had to be sent to their new home in "pokes." Mr Williams of Harrogate took a Mistress Mary two-year-old at 120 gs., and a Maude at $71 \mathrm{gs.}$ Mr Duthie had Captain of the Guard at 58 gs., but the fine old bull had received a jerk in his back. Mr James Sidey took the gaudilycoloured, but perfectly-shaped, two-year-old Ladas at $40 \mathrm{gs}$, and the bull proved a wonder-worker in the Argentine.

Mr Fisher was anything but an orthodox hotelkeeper. He could not be all things to all men. Therein, and in a distinct strain of gentlemanly bohemianism, lay much of his charm. Neat in features and attire, with hints of complacent, confident militancy in nose and dancing eyes, he had the pluck of a true-blue fighter, and a generosity and hospitality that never failed. An ardent politician, and admirer of the tree-felling G.O.M., he was not to be attacked in extended or close formation. Down he came like a Prince Rupert, thrusting, parrying, smiting, and filling in the gaps with light-horseman raillery. A very few days afterwards he might be on the Haughs of Ballechin, or somewhere else, wholeheartedly discoursing Shorthorns with two or three of the "enemy"!

Fisher had a genius for making friends, and a gift for subjecting them to passing irritations. A bright 
optimist until well-nigh a troubled fourscore, and quick as a bird in observation, he had a great deal of what one might term pot-shot talent and shrewdness, but in matters which required something of a student's faculty he naturally hopped at times to wrong conclusions. Still, he was an attraction. Unfortunately for himself, he rarely took account of a coming "rainy day," and he died poor.

In the sixth decade of last century the Kinkell herd, already referred to, and Mr Drummond's at Marlfield, to be further dealt with, were the best known in West Perthshire. Mr Turnbull had then and later a herd of more than local repute at Huntingtower. Over fifty years ago Mr John Drummond, a successful Glasgow contractor, acquired the property of Blackruthven and began to found a herd in 1869 with selections from Keir, the Duke of Montrose, Huntingtower, Sittyton, Blebo, Windsor, Rossie Priory, and Elmhurst Hall. In its mid-course the herd, which rapidly came into the flush of prizewinning, was a good blend of Booth, Sittyton, Knightley, and Bates blood. The most noted family at Blackruthven was the Orange Blossom. From $\mathrm{Mr}$ Amos Cruickshank Mr Drummond acquired Orange Jelly, by Lord Lansdowne $(29,128)$. 'To the Sittyton Baron of the Isles $(36,196)$ Orange Jelly produced Orange Jelly 2nd, which in her turn bred Orange Jelly 3rd, by the Dunmore Lord of Alabama $(38,630)$. The 2 nd and 3 rd of the family passed into the possession of Mr Thomas Lawson of Carriston, Fifeshire. Mr Lawson put Orange Jelly 3rd to the Sisterpath 
bred Cherry Shoot $(49,268)$, and the result was Cherry Blossom, which was sold to Sir John Gilmour. In these days there are frequent discussions as to whether the "straight-bred" Cruickshank Orange Blossom or the branch with the Bates cross is the better. On the whole, Mr Drummond tried too many experiments, and in 1880, when he sold off, it was at a considerable loss. He next disposed of his property and returned to his contracting business. His first bull of note was Baron of the Isles $(39,196)$, from Sittyton. That sire was followed by a representative of the Vesper family from Braithwaite. Towards the final the Dunmore Red Rose bull, Lord of Alabama $(38,630)$, was in use. At the Blackruthven sale the average for 42 head was only a little over $£ 25$. 
CHAPTER IV.

George, Lord Kinnaird-His varied interests-His Shorthorns-The Hunters and Patrick Kinnear-His lordship's critics-Lumsden \& Mackenzie-Successful herd-John Drummond, CultmalundieHugh Watson, Keillor-His Ury Shorthorns-Friendships with Shorthorn breeders-Inches, Dalgairns, Hood, Stephens, and others -Rennie, Earl of Airlie, Arklay, James Swan-The GrangersTaylor, Charles Lyall, David Hume.

Aт beautiful Rossie Priory, by the edge of the fertile Carse of Gowrie, George, Lord Kinnaird, had a herd for nearly forty years, and if he was not quite so keen on exhibiting as he was on steamploughing, improved implements, drainage, and phases of social reform, he did not miss his opportunities when the Highland came within fair reach. His lordship began by purchasing bulls from Earl Spencer for the use of his Carse of Gowrie and district tenants, and after a short trial he began to form a herd of his own. He was no doubt stimulated by his enthusiastic neighbours, the Hunters of Glencarse and Monorgan, and Mr Patrick Kinnear of Lochton and Littleton. Those gentlemen had well-known herds during the twenties and thirties of the century. One of their most successful joint-speculations, according to Dickson, was the purchase from Mr Rennie 
of the red-and-white bull Linton. At Glasgow, in 1867, the Rossie Priory herd bore off the firsts in the heifer classes with the two-year-old Royal Helena and the yearling Baroness. One of his lordship's notable bulls was Cherry Duke 2nd, an animal of grand appearance but an indifferent breeder, at Shethin in any case. Mr Shepherd had bought him for 205 guineas in 1856 at $\mathrm{Mr}$ Atherton's sale near Liverpool. After two years' use at Shethin the bull was passed on to Rossie Priory. In his mid-career as Shorthorn breeder and land improver Lord George had a few candid critics. One of the most aggressive was a West Carse auctioneer and farmer, whose letters in hybrid Johnsonian English still form amusing reading for the curious.

A herd which had an excellent record for a good many years was that owned by Messrs Lumsden \& Mackenzie of Huntingtowerfield. Even when they had very few pure-bred cows, those enterprising gentlemen attracted attention by the high-class character of the bulls which they bought at the Perth sales. On several occasions they took out the first-prize winners at prices which were considered exceptionally high for the times. In 1887 the foundations of a pedigree herd were laid. About $1890 \mathrm{Mr}$ Lumsden bought a pair of very good heifers from Lord Lovat. These were of the Dairymaid and Annie families, and their sire was the fine bull, Lord Violet. Several years later he acquired at a Beaufort sale Lady's Maid 13th, and she bred at Huntingtowerfield the very handsome Marchmont, which won 
1st prize at Perth in 1901 and drew 131 guineas, the top price of the sale. Later on members of the Lady Dorothy, Clipper, Victoria, Graceful, and Missie families were added. In 1904 the herd won the senior and junior first prizes at Perth with sons of the Irish-bred Prince Fortinbras $(79,618)$. The bulls were Prince of Huntingtower, out of Fair Maid, and Viceroy of Huntingtower, out of Lady Dorothy 39th. Those bulls, along with a half-brother, won the group prize, and the two class winners were sold at 400 guineas each. Prince Fortinbras, which was bred by $\mathrm{Mr}$ William Armstrong, was the best stock bull ever used in the herd. He was a beautifully-balanced roan with a splendid back and deep flanks. Unfortunately he was sold for exportation before his full value as a breeder was discovered. The herd, which had been gradually reduced in numbers, was sold off in 1914.

Mr John Drummond, a most interesting man, father-in-law of the late Mr Alexander Hay, livestock salesman, Perth, had a well-bred little herd for nearly thirty years. Mr Drummond laid the foundation about 1850, when he was farming Marlfield, near Tibbermuir, and he took his cattle with him to Cultmalundie Mains in 1860. His principal adviser at the outset was $\mathrm{Mr}$ William Turnbull, Huntingtower. From 1860 onwards most of his cattle were of the Norah family, tracing back to Lucy, by Borderer (3191). Latterly, Mr Drummond had representatives of the Duke of Montrose's Ballet Girl strain. He always selected well-bred bulls from such breeders as Sir Thomas Buchan 
Hepburn, Bart., Messrs Cruickshank, Mr J. Maxtone Graham, Mr Andrew Mitchell, Mr Turnbull, and Mr Robert Geekie, but he did not trouble himself regularly with registration. In $\mathrm{Mr}$ Drummond's private herd-book the note occurs once or twice, "Sold to Mr Todd." This was Mr Wm. Todd, Mains of Gorthy, near Methven. Mr Wm. Drummond Todd, son of $\mathrm{Mr} \mathrm{Wm}$. Todd, writes: "My father bought a good Shorthorn bull every second year as far back as I can remember. About 1882 he bought a few pure-bred heifers from Mr Donald Campbell, Shearerston. When I succeeded him I won many prizes at the local shows, but I sold the cattle over twenty years ago, owing to want of proper housing accommodation."

Turning towards Strathmore, Mr Hugh Watson, Keillor, kept a small herd of Shorthorns prior to 1840. In the forties he had very fair success at the Highland Society's Shows, but he appears to have sold off his horned cattle in 1847 or 1848 . Watson's portrait represents a man of great practical talents; resolute, cautious, with keenly acquisitive eyes, and hints of the secretive. The short cheek-whiskers are brushed forward in Palmerstonian fashion, and the side hair is neatly set up towards the bald dome. He and Captain Barclay were "fell chief," according to the testimony of $\mathrm{Mr}$ Robert Geekie, and that was surely a better way of expressing it than to say that the two were uncommonly friendly. They were interested in the Perth to Aberdeen mail-coach, as they supplied horses for 
the journey. When Captain Barclay was forming his herd he sought advice from Watson, and at the Ury sale of 1838 the understanding with some was that Wetherell took out the thirteen-year-old Lady Sarah for Keillor. In any case, Watson then bought the cows, Lucy by Mars, and Susan by Champion. With the Laird of Ury he continued to be on the most intimate and friendly terms, and he loved to meet the Booths, Wetherell, Mitchell, and other prominent men in the Shorthorn ranks. In 1848 Colonel Dalgairns of Balgavies, Forfar, showed a bull bred at Keillor. The Balgavies herd was well known beyond the bounds of the county.

In Forfarshire, the Coupar-Angus district probably took the lead in extending hospitality to Shorthorns. Mr David Inches of Cardean, who founded a herd with stock from the Messrs Wilson, Edington Mains and Simprim in Berwickshire; Mr Andrew Dalgairns, Ingliston; $\mathrm{Mr}$ Anderson, Newton, and Mr Hood, Hatton of Eassie, had herds which came into note during the third decade of the century. Mr Henry Stephens, afterwards so well known as an agricultural writer, was a Shorthorn pioneer while farming Balmadies in the eastern part of the county. His first purchase was from Mr Brown, Whitsome Hill, Berwickshire. For eight years he had a much-admired red-and-white bull named Brown in honour of the breeder. This Brown was by the red-and-white Ladykirk bull Valentine, out of a cow descended from the stock of Mason of Chilton. Mr Stephens sold his herd in 1830, and 
prominent buyers were Mr Rennie, Kinblethmont Mains, $\mathrm{Mr}$ Hood, and $\mathrm{Mr}$ Cobb of Mains, near Dundee. In arable farming, as in many other matters, Mr Cobb was a man of advanced views. One of his most enthusiastic neighbours in Shorthorn breeding was Mr Anderson, Carlungie, Monifieth.

From about 1825 onwards to the early forties a finely-bred herd, founded on Ladykirk blood, was owned by $\mathrm{Mr}$ James Rennie, of the Phantassie family, at Kinblethmont Mains, near Arbroath. Mr Rennie did not exhibit extensively, but his cattle were sought after by discriminating breeders. It was at Kinblethmont Mains that the Messrs Cruickshank acquired a Venus in 1841.

A few well-bred Shorthorns were kept by the grandfather of the present Earl of Airlie before 1865, but results were rather disappointing. Before that time, and on to the eighties, Mr Robert A. Arklay of Ethiebeaton, Monifieth, was a keen supporter of the Shorthorn interest. Shorthorns had been in possession of the Arklay family from the twenties of last century. The Arklays then farmed in North-East Forfarshire. Mr Robert Arklay's most noted bull was Master Toddles (40,331), with which he took the H.C. Card at the Highland. A finer show bull was Annan Water $(27,885)$, which won for him at Perth Highland Society in 1871. Those sixties and seventies were quiet times for the average file of men outside the Booth and Bates camps, and a worse period was ahead, as the Cruickshank star was only faintly twinkling in its ascent. Ethiebeaton at its best was 
hit off by quaint, lovable Mr David Smith, Murroes, arable farmer, feeder, and dealer. "Robert Arklay has just a maggot [fad] for braw bulls, an' muckle, fat, half-idle coos, but gin he was like me he wid be lookin' for something to pey the rent." Mr Arklay died in November 1893. All his cattle had been disposed of gradually before 1887. A number had been sent to the fat-stock market.

A little farther east, on the coast side, Mr James Swan, Inverpeffer, took an early liking to the breed, and had several transactions with Mr Arklay, but by $1884 \mathrm{Mr}$ Swan sold nearly all his pure-bred cattle to Mr David Hume, Barrelwell, who was then settling down to a home life, after being a number of years in the American export business.

For nearly thirty years the Pitcur herd, which was dispersed on 17th October 1903, was well known. Mr John Granger, the founder, had been a highly capable and enterprising contractor for railway cuttings and other operations. Shortly after he took a lease of the pleasantly set farm of Pitcur, at the foot of the Sidlaws, near Coupar-Angus, he secured a few fine females of the Groat, Matadore, and other families from Cambushinnie. His son, Mr John Granger, who succeeded the founder, added members of the Mina, Diamond, Lady Dorothy, and Beauty families, but the Groats were the best cattle right along. At the sale cows ranged from 36 gs. to 75 gs., and three of the yearling heifers went at $55 \mathrm{gs}$. to $70 \mathrm{gs}$., but for the calves prices were poor, and the general average for 65 animals was $£ 24,9$ s. 2 d. The heifer, Bella Groat, 
by the exported Count Nicholas $(76,435)$, was taken out by Mr Norris for Earl Manvers at 55 gs., and she became the dam of the famous Royal English champion of 1910, Duke of Kingston 2nd (102,088). Count Nicholas, bred by Mr Duthie, was a massive, level-fleshed, but rather high-standing roan, by the white Count Arthur, a son of Count Lavender.

At Pitlivie, near Carnoustie, a very large and fashionably-bred herd was owned by the late $\mathrm{Mr}$ Robert Taylor, better known as Bailie Taylor. Its foundations were laid in 1890 , and for about seventeen years exhibiting was conducted on a great scale, and championships were won at the English Royal, the Highland Society, the Royal Dublin, and other open shows. During the period referred to an extensive export trade was conducted. Among the bulls used were the champions, Collynie Conqueror, the Jackstown-bred Royal Emblem; also March On, Scottish Wanderer, and Cyprus King.

One of the most vigorous and successful of exhibitors during the forties was $\mathrm{Mr}$ John Millar, Ballumbie. About $1850 \mathrm{Mr}$ Charles Lyall, latterly of Old Montrose, and agent to the Earl of Southesk, founded a herd at Kincraig. His start was with four animals from Ury. He had Booth and Bates blood in his herd at later stages, but in the main his leaning was towards Kirklevington, as he thought cows of such descent were the better milkers. The most noted bulls were Lord Dunmore's Crown Prince $(28,281)$ and Colonel Kingscote's Duke of Dursley $(25,953)$. In 1865 he lost 56 head through rinder- 
pest. When the herd was dispersed on 7 th October 1874, immediately after the sale of the Earl of Southesk's Herefords, there were five families in it descended from Ury, Shethin, Mr Barber's herd, Yorks, and Mr Atkinson's Northumberland. The most fashionable family was the Bates-descended Duchess Nancy, and the most numerous the Shethin Mysie. The cattle were in somewhat thin condition, and the average for 36 animals was slightly over $£ 30$. Mr Lyall, a man of substantial mental endowments, was highly esteemed as a neighbour.

Mr David Hume, Barrelwell, was a force in Forfarshire agricultural, stock-breeding business, and public life for many years, and in every practical sphere he won distinction. His swank figure, alert mind, and polished yet frank speech commanded attention, and at meetings where questions affecting land, stock, and exhibiting were concerned few could match him in suggesting a straight and sensible course out of a tangle. He founded his Shorthorn herd in 1880 with the best materials locally available, and built up a generally good show of females by the use of firstclass Cruickshank bulls. His principal sires were Masterpiece $(57,730)$, a close relative of the champion Mario, Red Knight $(50,286)$, Violet Chief $(66,474)$, Viking (84,988), Ballachraggan Baron (85,208), Prince $(89,587)$, Diamond Emerald (94,874), and Diamond Silver Star. During the last few years of his life Mr Hume used with much effect front-rank bulls owned by Mr Donald Maclennan. From time to time he exported some of his best heifers, and that was 
against his herd latterly. Mr Hume died, after a short illness, at Montreaux, on 16th February 1908, and his herd was sold on 12th October of the same year. A good many of the cows were up in years, and colours were not quite popular. Prices ruled low, although most of the cows were in calf to the Jackstown-bred Baron's Voucher, which had won first at Perth in spring. There were some showy calves by the Ballechin-bred Silver King, a son of the Argentine $£ 2000$ bull Marquis. The Star Princess cows and heifers made the best appearance, but the leading price was only 40 gs., paid by Major Stirling. For 53 animals the average was $£ 17,2$ s. $4 \mathrm{~d}$. His Star Princesses and Marchionesses were from one old Eryholme foundation. They had been bred by Mr Arklay, and $\mathrm{Mr}$ Hume, as already noted, acquired them from $\mathrm{Mr}$ James Swan. 


\section{CHAPTER V.}

General Simson-His important work-Sam Wiley and Sultan-General Watson-Bethune of Blebo-His Roses-Barclay of Keavil-Remarkable herd-Heir of Englishman-Sir John Gilmour-Noted stock-Dispersion sale.

General Simson of Pitcorthie, Fifeshire, was one of the most remarkable men in Shorthorn annals. In all probability he was breeding Shorthorns before 1789. Be that as it may, he hired bulls from the Collings in 1789 and 1791. In 1806 he paid Charles Colling $£ 300$ for the cow Mary. She was by Favourite (252), out of Venus, the notable daughter of Ben and Phœenix. At that time also he had the courage to hire at $£ 100$ per season the bull North Star (458), a full brother to the 1000 gs. Comet (155). North Star was only a calf when he was hired, and at the end of 1808 Robert Colling pressed the General to return the bull, so that he might be used by Charles Colling during season 1809. There must have been some ambiguity in the terms of the hiring, as the northerner kept the bull, and paid the $£ 100$ yearly. North Star died in General Simson's possession when five years old. Through the stock of Rolla, a son of North Star, Mr John Grey, of Millfield and Dilston, 
had striking successes. North Star blood proved highly effective also at Ladykirk through Sultan (1485), as that bull was out of a cow by the "Star." The herd at Pitcorthie was a small one. When it was dispersed on 11th October 1818 its strength was 37 head-12 cows, 5 two-year-old heifers, 4 one-yearold heifers, 7 bulls, 3 bull calves, and 6 heifer calves. The general average was almost $£ 40$, and the English purchasers considered they had got "great bargains." Sultan ultimately came into the possession of Sam Wiley of Brandsby, and there he produced Sultana, which became the dam of Carcase (3285), a great show bull and noted breeder.

Writing to Cottrell in 1833, Mr Wiley recounted: "Now I have got a bull out of the North very much to my mind. $\mathrm{He}$ is of great size; his breast is wide and deep; his shoulder points are very fine; his crops, fore rib, and girth are extraordinary; his hind ribs are the best, and come the nearest to his hips (which are wide and handsome) I ever saw; and what is best of all, his inclination to fatten surpasses that of any bull I ever fed." Then he goes on to state that the bull's name was Sultan, and that he was hred by General Simson. As Sultan was calved in 1818 , he was fifteen years old when Wiley wrote as above noted (Sinclair's History, pages 384-85).

In Bell's History it is stated that General Watson of Aberdour, Fife, bought Princess, by Hubback, from Charles Colling, in 1789, but I have been unable to find any reference to this General in any contemporary writings. 
Coming to modern times, the herd owned by $\mathrm{Mr}$ Alexander Bethune of Blebo had a successful course for many years. The herd, which was founded about 1860 , was almost cleared out by rinderpest in 1865 , but with two cows and the bull Master Blithe $(29,314)$ from Alloa, Mr Bethune set out again as a breeder. At Alloa, in 1870, he secured the fine red cow Bessy Bell, by Lord Eagle out of Blue Bell, by Knight Errant $(18,154)$. She had a heifer calf next spring by Baron Booth. He made an important purchase at Costerton on 18th May 1869, his selection then being the famous Highland Society winner of 1868, Romping Girl, by Enoch Arden $(23,890)$ out of Brown Girl, by Sir Jacob Wilson's noted Duke of Tyne $(17,751)$, the Worcester Royal first-prize winner. At the sale of Mr Millar's famous Singleton herd, Mr Bethune acquired Ringlet 14th, of the highly-esteemed line which won the family prize at the Bristol Royal of 1878; and at that disposal also he selected Rose Flower, of Mr Bruere's favourite blood. Ringlet 14th was a massive white by Lord Prinknash $(34,655)$. There was much of the old Booth grandeur in one of Mr Bethune's later purchases-that of Aylesby Foggathorpe, for which he paid $225 \mathrm{gs}$. at the Aylesby Manor dispersion sale in 1875. He bought a most handsome cow also from Mr Unthank of Netherscales. That was Lady Havelock, by the almost pure Booth bull Antonius $(27,902)$, and in her new home she produced the beautiful heifer calf Dewdrop. More Booth blood was introduced through the Sir Simeon cow Eastthorpe Rose 2nd and her heifer calf, 
purchases at the West Dereham sale of 1883. $\mathrm{Mr}$ Bethune's own Roses, as he termed them, were of Leconfield descent through Rock Rose.

Master Blithe, which was used for six seasons at Blebo, had for sire Mr Booth's Lord Blithe, own brother to the Royal Show cow Lady Fragrant. Other bulls used in the Blebo herd were King Brian (34,308), Hochstapler (36,776), and Major $(41,556)$. Two bulls of Mr Hugh Aylmer's breeding followed, and most of the young animals catalogued for the dispersion sale held in August 1885 were by Prior, bred by Mr Andrew Mitchell. There were a good many descendants of Romping Girl on the sale list. Two of these, Strawberry 21st and Strawberry $27 \mathrm{th}$, were acquired by Mr J. J. Moubray of Naemoor at 50 gs. each, and the 26th of the line was bought for Montrave at 41 guineas. Five two-year-old heifers averaged $£ 45,3$ s., but the average for 46 head was only $£ 26$.

A herd which rapidly came into distinction between 1860 and 1865 was that owned by Mr George R. Barclay of Keavil, Dunfermline. The herd was managed by a man of genius in the breeding art- $\mathrm{Mr}$ Thomas Easton, afterwards so well known as agent to the Rev. Thos. Staniforth and Mr Edmund Potter. Among the earlier purchases were Fan Fan, a daughter of Mr Sanday's 225 gs. Faith; Seraphina 13th by John o' Gaunt, which cost 240 gs., also a few selections from Panton, Babraham, and Sittyton. The Seraphina family, however, proved by far the best at Keavil. The principal bulls used were Mr Jonas 
Webb's Englishman (19,701) and Baron Booth (21,212). At the sale of the herd, 21st September 1869, the average for 27 animals was $£ 58,16$ s. 9 d. Seraphina 13 th, then a nine-year-old, passed out of the ring to Lord Sudeley at 110 gs. His lordship also took two daughters of the old cow, full sisters, in Seraphina Carissima, a roan two-year-old, and the red with little white yearling Highland winner, Booth's Seraphina. These were by Baron Booth, and they cost 120 gs. and 150 gs. respectively. The white seven-year-old Fan Fan went at 165 gs. to $\mathrm{Mr}$ Whyte Clinterty; but the roan, Anne of Lancaster, of like age, which had cost Mr Barclay 150 gs., drew only 54 gs. from Mr Reid, Daneston, her yearling daughter going to Mr James Beattie, Newbie, at 71 gs. The great bull for sale at Keavil was the highly distinguished prize-winner Heir of Englishman $(24,122)$, the four-year-old son of Englishman and Seraphina 13th. Mr Wm. S. Marr, Uppermill, who had tried to buy the bull when exhibited at one of the earlier shows, was then scared off by a price of 1000 gs., but at the dispersion sale the far-sighted Uppermill breeder had a surprise and delight in securing his choice at 100 gs. Looking to results at Uppermill, the "Heir" was one of the cheapest bulls ever bought. Baron Booth fell to Mr Mitchell; the twenty-two-months-old Frederick Fitz Booth went to Mr R. Challoner; and Prince George, a red with little white calf, out of Seraphina 13th, passed to Mr Wm. Duthie.

The Montrave herd, owned by Sir John Gilmour, Bart., one of the best of men and truest of sportsmen, 
produced numerous prize-winners and some grand stock bulls during its career of fully thirty years. Founded in 1885, its principal purchases in the earlier years were Strawberry 35th from Blebo; Cherry Blossom and Rowan Blossom, members of the famous Orange Blossom family, from Mr Lawson of Carriston; a Clipper, of Newton descent, from $\mathrm{Mr}$ George $\mathrm{R}$. Fortune; Passion Flower, of the Pansy Blossom line of Carnations, from Ballechin; and Derwent Gwynne from Edengrove. Later purchases included Clear Star and Spring Rose from Windsor; Lady 18th and Butterfly 47th from Balnakyle; Blithe Elsie from Naemoor; White Rose and Fannie from Orchardmains; a Buttercup from Strowan; and Beaufort Rosemary 2nd from Lord Lovat. By degrees, most of the families so well known when the herd was in its mid-course were gradually disposed of, and when the herd came to be sold at Aberdeen on 10th October 1917, Clippers were in almost full command. Nineteen females of that popular family were catalogued. There were also representatives of the Rosewood, Golden Drop, and Butterfly lines of blood.

The bulls used in the Montrave herd were the very finest. Among these were the Ballechin Excelsior $(57,812)$, a son of Pansy Blossom; the very pretty prize-winning Gem of Pennan $(59,002)$; the Collynie-bred Bridegroom $(66,728)$ and Brave Archer $(70,018)$; the Uppermill Spicy Baron (77,944); the beautiful home-bred champion Royal Archer $(82,157)$ by Brave Archer; Broadhooks Conqueror $(85,451)$; Royal Victory $(100,486)$, the 600 gs. bull 
at Perth in 1906 ; and Duchlage Secret $(125,262)$, by Cupbearer of Collynie. Brave Archer, by Scottish Archer out of the remarkable Miss Ramsden cow Bright Belle, was one of the best stock bulls ever used in Central Scotland. His heifers, especially, were the admiration of all judges. His son, Royal Archer, a bull of medium size, showed beautiful character and a perfect back and hindquarters, but he was only a fair success as a breeder. Some of the Clippers catalogued for the dispersion sale were rather pale in their roan, but all displayed high-class character in union with substance. Competition was keen. Twelve cows averaged $£ 277,7$ s. 6d.; six heifers, $£ 172,7$ s. 6 d. ; and ten calves, $£ 163,9$ s. 8 d. ; the general average for 28 head being $£ 214,4 \mathrm{~s}$. The Hon. Claud Portman paid 440 gs. for the four-year-old Montrave Golden Drop, her beautiful heifer calf by Duchlage Secret going to Colonel Fenwick at 240 gs. ; Mr Edmond, the Mentmore agent, paid 400 gs. for the four-year-old Clipper, Montrave Esther, and 210 gs. for her pretty heifer calf by Butterfly Royal (130,032); and Mr Ralph M'William, Stoneyburn, went to $370 \mathrm{gs}$. for Montrave Eva 3rd, a sweet red two-year-old Clipper with a promising heifer calf at foot. 


\section{CHAPTER VI.}

Christie, Dairsie Mains-His noted cattle and sales-G.O.T. and James Bruce-John Hill, Langside-James Carnegie, Thomas LawsonMeiklem Brothers, G. R. Fortune-Andrew Mitchell-A Booth herd -His sale-His personality-Duke of Montrose's herd-Simon Beattie and Rosedale-William Alexander, Loanside.

Mr Frank W. Christik, who has spent the greater part of his very active and public-spirited life in Fifeshire, had a widely-known herd when he was tenant of the large farm of Dairsie Mains, near Cupar. The foundations of the herd were laid in 1879 with purchases from Polmaise and Coldstream, and animals were bought in succeeding years from Collynie, Dunira, Uppermill, Newton of Insch, Mill of Dumbreck, and Kinellar. Stock bulls were mostly selected from the Alloa and Mertoun herds. The best families were the Orange Blossoms, Claras, and Gwynnes. The Uppermill Clara cow, the 46th of her line, and by Sittyton Scarlet $(58,163)$ from a dam by Athabasca $(47,359)$, won many prizes in the county. Among the earlier bulls used were the Blebo Lord Blithe $(53,129)$, Montgomery of Cluny $(56,200)$, the Alloa Hildebrand $(57,462)$, and the Collynie Fortune Hunter $(62,616)$. The herd was almost sold off in 1894 . 
Prices ruled low, the average for 60 head being only $£ 18,15 \mathrm{~s}$. 6d. Mr Carnegie of Aytounhill paid the top price of $44 \mathrm{gs}$. for Clara 46 th.

In $1895 \mathrm{Mr}$ Christie bought back the Clara cow, and she proved a great breeder, her most noted son being Moonlight $(75,110)$. An Uppermill Missie by Lord Lavender $(54,616)$, a Ury Maid by Scottish Archer (59,893), a Northumberland Rosebud by Prince Palatine $(57,933)$, a Sittyton Victoria from Powburn, and by G.O.T. $(65,603)$, a Rock Rose, a Jealousy, and other families were acquired. Of the bulls in use during the second period the best were the Collynie-bred Clinker $(66,846)$ of the Clara family, by Gravesend $(46,481)$; his homebred son Moonlight, the red Goliath $(65,600)$, bred by $\mathrm{Mr}$ George Bruce, and the Montrave white, Archer's Heir $(76,037)$, by Brave Archer. The herd was dispersed on 21st September 1901, at fair prices. The averages were, 18 cows, $£ 33,6$ s. 9 d.; 12 calves, $£ 19,12$ s.; 15 heifers, $£ 28,7$ s.; 5 bulls, £28, 2s. 9d. Mr Duthie paid the highest price, 85 gs., for Sunflower 15th, a good five-year-old roan of a well-known Woodend family, and by the Sittyton Coldstream $(60,510)$. Moonlight had been sold previously to Mr John Handley, in whose possession he won third in the aged class at the Inverness Highland, in addition to several firsts and two championships at the English shows. Sold to Mr Morgan Richardson, he became the sire of a number of champions, among these being Meteor and Massena. Moonlight was a roan of grand character, very smooth, deep, and 
mellow in flesh, and he always kept in condition on plain fare.

The bull G.O.T., referred to in the foregoing paragraph, was bred and named by $\mathrm{Mr}$ James Bruce of Inverquhomery, and used by Mr Stott, Powburn, Kincardineshire. The bull was a good-bodied roan, but with dark-tipped horns, and his nose was not quite orthodox. Born when the first Home Rule controversy was running its course, his breeder resolved to ring a change on the Grand Old Man (Mr Gladstone) - "Grand Old Traitor, that's fat he is," was the Northerner's verdict. Mr James Bruce, tall, angular, strong-featured, with piercing grey eyes and smiting tongue like that of a Hebrew prophet, had a scientific brain and a great heart.

For many years, up to the early part of this century, Mr John Hill, Langside, had an excellent little herd. He had very good Roseflowers and Lancasters, and from Montrave he acquired a very fine descendant of Romping Girl. Mr Hill was a most observant, highly-intelligent man, a first-rate farmer, and a tasteful judge of an animal. The best Shorthorn ever bred by him was Nonsuch $(65,969)$, with which Lord Polwarth won the Highland and Royal Championships in 1894-95. As an old bull, Nonsuch was one of the grandest-looking specimens of the breed that any show-goer had seen for a long time. His sire was $\mathrm{Mr}$ James A. Gordon's Chief Secretary $(55,467)$, and his dam was Roseflower 2nd by Cherry Shoot $(49,268)$, bred by Mr G. Torrance. Like Royal Herald and Linksfield Champion, Nonsuch came to 
his best somewhat slowly. As a two-year-old in his breeder's possession, he was placed second at the county show to Sir John Gilmour's Gem of Pennan.

During the eighties, and in the early years of this century, Mr James Carnegie of Aytounhill showed some beautiful cattle. His best were of Blebo foundation. His Rose or Rock Cistus family was from Rock Rose, and his Strawberries were from Romping Girl. Mr Thomas Lawson of Carriston was also a considerable exhibitor at the county shows for a fairly long term. His leading family was the Orange Blossom with the Bates cross in it. At Balbirnie Mr Balfour kept a herd of about twenty cows during the late sixties, and on throughout the seventies and eighties. He won first in the two-year-old bull class at Perth Highland in 1871 with Keir Butterfly 7 th $(31,457)$. The last stock bull used was from Dalkeith Park, and he cost 100 gs. During the last twenty years a few well-bred Shorthorns have been kept by the Messrs Meiklem, the well-known Clydesdale breeders. Before he took up the agency for Balcarres, the late Mr George R. Fortune had a small herd of fine breeding at Pilmuir. He had a few Clippers of Newton descent.

On the grassy haughs of Alloa, by the links of the Forth, Mr Andrew Mitchell had long extended recreative hours among his Shorthorns. As a young man in the thirties of last century he would fain have set out as a breeder of the red-white-and-roan, but business demands were then too strong. In 1855 he visited Carlisle Royal Show, where he formed a 
strong admiration for the leading aged bull Windsor (14,013), with which Mr Richard Booth had taken the male championship. Windsor was by the remarkable sire Crown Prince, and out of Plum Blossom, the female champion of 1851. A visit to Warlaby followed, and at that homestead he fixed upon First Fruits as the bull which he would hire when he had collected a few cows and heifers. Along with Mr John B. Booth, he afterwards attended Mr Crawley's sale at Luton, and purchased the heifer Mistletoe at $74 \mathrm{gs}$. She became a noted prize-winner, and Malvolio, a roan son of hers by Brigade Major, became well known. In $1857 \mathrm{Mr}$ Mitchell again visited Yorkshire, and the result was the purchase of several animals from Mr Jolly and Mr John Wood. For bulls he held to Warlaby and Killerby. First Fruits and Prince Arthur were followed by Brigade Major, Lord Blithe, and Banner Bearer.

In 1870 the herd had overtaxed its accommodation and a sale was held, when 47 head averaged $£ 50$. The most noted female animal disposed of was Bluebell, which passed to the Hon. M. H. Cochrane at 160 gs. A considerable section of the land was then given up, and the herd was afterwards a small one. In its later years it was strengthened by the selection of good females from the herds of the Rev. Thos. Staniforth, Sir Jacob Wilson, Mr Wm. Torr, Mr Hugh Aylmer, Mr Donald Fisher, and Mr John Wood. It was typically Booth in character, the cows in general being large-framed, with wide ribs and strong backs. Some of them, however, had gone from breeding at 
too early a stage. The dispersion took place on 3rd September 1894. The Earl of Mar and Kellie, the proprietor, occupied the chair at the luncheon, and among those present were Lord Polwarth, Lord Rathdonnell, Mr Wm. Duthie, Mr J. Deane Willis, Mr Chandos Pole-Gell, Mr William C. Booth, Mr Wm. Tait, Windsor; Mr Donald Fisher, Mr Wm. Graham, and Mr Robert Bruce.

The top price of the sale was 105 gs., paid by Mr Hollington for Eastthorpe Belle, a two-yearold by the home-bred His Highness. Mr Hollington also took Flower of June of like age, and by the same sire, at 75 gs.; Mr Pole-Gell paid 86 gs. for the four-year-old Eastthorpe Queen, by a son of Flower King. Mr Staniforth went to 73 gs. for Flower of May, by Sir John Studley, and Lord Polwarth secured Weal Wave by Boniface, at 62 gs. For 44 cows and heifers the average was $£ 31,19$ s. 4 d., and for three young bulls it was $£ 17$, 3s. 10d. Of Mr Mitchell it could then be said that, although fourscore and three, his eye was not dim, and his mind was unclouded if his natural force was abated. A kingly man mentally and physically; strong, serene, and kindly in countenance, Mr Mitchell's personality impressed his generation. He died on entering his eighty-seventh year, 24th March 1897.

During the fifties and sixties of last century the Duke of Montrose was a man of note in the Shorthorn world. When his herd was sold in 1867, along with the Strathallan cattle, the most famous animal 
in it was the roan six-year-old cow Rosedale, bred by Lady Pigot, and by Valasco $(15,433)$ out of Rosie, by Master Belleville (11,795). As a calf she won at Northampton; as a yearling she was commended at the Battersea Royal, and had firsts at many other shows, including Durham, North Lincoln, Halifax, Preston, and Warrington, also a $£ 100$ challenge cup. Then as a three-year-old she won at the Worcester Royal. When Rosedale was at her best as a cow, the beautiful little Queen of Athelstane was winning all round for the Hon. David Christie in America. Mr Simon Beattie attended the Montrose sale specially to buy Rosedale in order to stop the all-conquering career of the "Queen." Mr Beattie had to pay 235 gs. for his favourite, as Mr Young of Keir was against him, but the buyer had the satisfaction of conquering all opposition in the American showyards during the following summer. Mr John Gibson described Rosedale as one of the best cows he ever saw: of great scale, feminine in character, long, wide, deep, and smooth fleshed. At the Montrose sale another grand cow was the six-year-old roan Flower Girl by Baron Killerby $(19,280)$, and winner as a two-year-old at Worcester Royal and Kelso Highland Shows. She was taken out for Keir at 100 gs. Scotch Rose, a yearling daughter of Rosedale and Scottish Chief, was bought by $\mathrm{Mr}$ Amos Cruickshank at $51 \mathrm{gs.}$ Other buyers included the Duke of Richmond, $\mathrm{Mr}$ Turnbull, Huntingtower, Mr Fox, St Bees Abbey, Mr Balfour of Balbirnie, and the Rev. Mr Storer. For 14 cows and heifers the average was $£ 67$, and 
for 6 bulls $£ 43,13$ s. 4 d. The animals were shown in excellent form.

For about twenty years down to the early part of this century Mr Wm. Alexander, Loanside, Clackmannan, kept a select little herd. Mr Alexander's Ophelias, descended from the Rettie-bred Ophelia by Baron Havering $(33,043)$, traced to a Ladykirk foundation. The $3 \mathrm{rd}, 4 \mathrm{th}$, and 5 th of the line by Grazier $(54,402)$ were very good cows. Mr Alexander was largely indebted to $\mathrm{Mr}$ N. Mackenzie, Northfield, as from that breeder he acquired three truebreeding females of Jenny Lind descent. These were Lady Marmion, a roan calved in 1883, and by Count Errant $(42,977)$; that cow's daughter, Lady Marmion 2nd, a red calved in 1887, and by Prince of Flanders $(51,905)$; and Cora Pearl 2nd, a roan calved in the same year and also by Prince of Flanders. Later purchases included Carmine, a roan of mixed Booth blood from Captain, afterwards Sir Charles Dundas, Bart.; Bertha Lass, a red with little white, from Mr Wm. Allen, Grassmanton; and Annetta 2nd, a red, from $\mathrm{Mr} \mathrm{Wm}$. Peterkin, and by the famous Chamberlain $(60,461)$, which ended his days at Ruddington Hall. Annetta 2nd was the best breeder of her time in Mr Alexander's herd. She was dam of the bull Carlo $(76,304)$, which is referred to later in connection with the Throsk herd.

A judicial-minded man of very good taste, Mr Alexander never did full justice to his natural abilities. He lacked ambition to some extent. In his later years he was undoubtedly hampered by indifferent health. 


\section{CHAPTER VII.}

Earl of Dunmore-Founding Bates herd-American transactions-His great draft sale-Duke of Connaught-Earl's appearance and character-John Moubray-Great land improver-His honours and prizes-East Lothian notables-George Rennie, Brown, CarnegieJ. C. Curwen, M.P., Thomas Bates, Judge Hepburn-Correspondence -Lord Althorp and John Grey-John Rennie-James TweedieJames Currie-James Douglas-His brilliant successes.

The late Earl of Dunmore was the only man who ever made a serious attempt on a large scale to found in Scotland a herd of pure Bates cattle. In 1868, when he set out as purchaser, his aim was to make the closest approach he possibly could to the Kirklevington cult. From Mr Stiles Rich, Didmarton, he acquired members of the Waterloo and Kirklevington strain. To them he added Mr Bowly's Musicals, also Siddingtons and Fawsleys. In the spring of 1871 he imported from the Hon. M. H. Cochrane of Hillhurst, Canada, the heifer 11th Lady of Oxford. From Mr Cochrane he at the same time bought for 2500 gs. the heifer calves Duchess 108th and four Roses of Sharon, bred by Mr Abram Renick, Kentucky. In Canada he also secured 8th Maid of Oxford and Marchioness of Oxford. By 1872 Lord Dunmore culled his herd down to Duchesses, Oxfords, 
and Red Roses, and to these he added from $\mathrm{Mr}$ Harward, Winterfold, a Wild Eyes cow and three of her female descendants at 210 gs. to $510 \mathrm{gs}$. In that year also he imported from Canada Third Duke of Hillhurst $(30,975)$, and three Red Roses from Kentucky. His purchases in 1873 were important and costly. From Mr Cochrane he took Duchesses 27 th and 101st, five Wild Eyes, and a Waterloo. The 101st Duchess was dam of one of the calves which his lordship had imported in 1871. When Sir Robert Gunter had exported the 101st and 103rd Duchess heifers, it was on condition that they were not to be returned to this country at any price. At a later stage Sir Robert relented and made an exception in favour of Lord Dunmore. The 6th Duke of Geneva $(30,959)$ was the notable male importation from Canada in 1873. Four Red Roses were taken at the same time from Kentucky.

In 1875 Lord Dunmore held his historic draft sale, the auctioneer being $\mathrm{Mr}$ John Thornton. Thirty cows and heifers averaged $£ 576,5 \mathrm{~s} .6 \mathrm{~d}$., and 39 head $£ 672$, 8s. The top price for a female animal was 1950 gs., paid by the Earl of Bective for Red Rose of the Isles. For Marchioness of Oxford 3rd the Duke of Manchester paid 1810 gs. The record-making bull was the two-year-old roan Duke of Connaught $(33,604)$, by Duke of Hillhurst, the price to Lord Fitzhardinge being 4500 gs. Third Duke of Hillhurst was taken at 3000 gs. by $\mathrm{Mr}$ J. W. Larking. On 27th August 1879 Lord Dunmore sold off all his Shorthorns. It was a depressing period, with 
continuous rains and a very bad outlook for harvest. For 54 head the average was $£ 241,14$ s. 3 d. When the Dunmore Shorthorns were at their best, some unprejudiced and capable men preferred the Red Roses to the Duchesses and Oxfords. The Roses were not only singularly beautiful, they were the more compact and thriftier looking cattle. It was supposed that the owner sympathised with the neutral judges. Certain friends relieved him by maintaining that Dunmore had two herds. Lord Dunmore was a handsomely-built, attractive man. He had bright parts in general conversation, and wonderful vivacity and charm when dealing with stock-breeding and sporting matters. As an allround judge he was one of the best, but as an evolver he was apt to be over-speculative. In his early manhood he had the misfortune to get his right eye destroyed by a ricochetting pellet when he was out with a shooting company at Blair-Atholl. As a young unan he spent many a happy day on his Hebridean property of Harris, whose people and language he understood and loved.

A remarkable man attracted attention beyond Central Scotland in the early twenties of last century. That was Mr John Moubray of The Moor and Cambus, a highly-skilled and advanced land improver, and a front-rank breeder and exhibitor of Shorthorns, pure and cross-bred cattle, and other stock. In 1826 he won the Highland Society $£ 20$ plate for having executed at his own expense on Cambus the "greatest extent of wedge-drains in clay 
and carse lands." In the style of the period, he is recorded to have drained 11,255 roods. "For waste land improved," the Highland Society voted him their Gold Medal in 1834. The land thus reclaimed was the desolate mossy area known as the Moor of Muckart, afterwards named Naemoor-a simple touch of Scots humour. At the Highland Society's first Show, which was held at Perth in 1829, Mr Moubray won the premium for best pair of Teeswater or Shorthorn heifers with one bred by himself, the other bred by Mr Hood, Yester. Both were descended from a notable bull named Duke. During the thirties Mr Moubray was a frequent and successful exhibitor of Shorthorns. At Stirling Highland in 1833 he was the breeder of the winning aged bull, and he won in the cow class against the Duke of Buccleuch, $\mathrm{Mr}$ Archibald Stirling of Keir, and other prominent men. In referring to the show, one of the Scottish journals noted the spirited efforts of $\mathrm{Mr}$ Moubray and $\mathrm{Mr}$ John Ritchie of Cultmalundie, Perthshire, in introducing Shorthorns to Central Scotland. Mr Moubray died in 1837, aged sixty-three years.

"There were giants in those days." That applies with special force to the East Lothian of the earlier decades of last century. George Rennie of Phantassie, who died in October 1828, aged seventy-nine, and Robert Brown, the accomplished, public-spirited tenant of Markle, who died in February 1831 at seventy-four years of age, had admirers all over Britain and even beyond it. Then there were Judge George Buchan Hepburn and John Carnegie of Hailes, 
who were keenly interested in Shorthorns. Mr J. C. Curwen, M.P., of Workington Hall, Cumberland, refers to three of the Scots just named in writing to $\mathrm{Mr}$ Thomas Bates in 1811. He had finished a curiously titled report: "Hints on the Manner of Feeding Stock and the Conditions of the Poor." $\mathrm{He}$ wished copies to be sent to Brown and Rennie. At the end of his letter he confesses, "Till this moment, I have forgotten Hepburn" (Bell's History). Judge Hepburn is very entertaining in writing to Bates (July 1813). The southern autocrat was a sworn bachelor of course, and the Judge advises him- "Come down to us when you can spare as much time, and cast your eye on our fair ones." He then switches into farming, and refers to his practice of carting straw to the field in order to mix it with the newly-cut clover. Of the mixture so won, he states, "My horses are fonder of it than pure hay." "We are contented, quiet, and happy," he notes, " and I thank God, we have no rascally, drunken, discontented weavers amongst us. . . . Our staples are wheat and bairns." The Smeaton herd, which was in existence for about eighty years, won many prizes at the Highland Society and locally. It was probably at its best between 1860 and 1875.

The Judge Hepburn who corresponded with Bates was born in 1739 and died in 1819. He was Judge of the Admiralty Court, 1790-91, Baron of the Exchequer in Scotland, 1791-1814, and was created a Baronet in 1815. The present baronet is a greatgrandson. Carnegie is subjected to a sidelight in 
The Druid's 'Saddle and Sirloin.' Lord Althorp, afterwards Earl Spencer, was one of the great Shorthorn enthusiasts of his period, and when he took up official residence in Downing Street his private herd-book was always on his desk. Mr John Grey of Dilston stepped in one day. His lordship gave a little dry laugh, "You've called about cows, sir, so you'll not have to wait long." The herd-book formed the text for the next half-hour. Then he handed $\mathrm{Mr}$ Grey a letter, "There's a letter," he said, "from Carnegie. He admires my political course, and he writes from the Lothians to say that I shall have the first refusal of his bull. I've written to thank him for his political confidence, but I've told him there is a flaw in his bull's pedigree. He traces him back to Red Rose, but Red Rose never had a heifer calf."

In a practical sense Mr John Rennie, son of $\mathrm{Mr}$ George Rennie of Phantassie, was one of the strongest of Shorthorn propagandists. He demonstrated that the breed was fit to lead the way in the paying sense. In 1818 he made his first selections from Ladykirk, and in November 1821 he suggested to the Directors of the Highland Society that a fat stock show should be established at Edinburgh. His suggestion was adopted, and the first show was held in Edinburgh in December 1822. Mr Rennie was well prepared for it. He won three first prizes for Shorthorns, and showed 23 steers of the breed as extra stock. In his collection he had a two-year-old Ladykirk-bred bull sired by Sirius. The following year he was the most success- 
ful competitor at the show, that being due in a considerable measure to Ladykirk. A twenty-monthsold steer in his group dressed 67 imperial stones $7 \mathrm{lb}$. During the next few years he sold many steers thirty to thirty-six months old, which dressed from 80 to 100 imperial stones, and in one year he sold 18 thirtymonths-old steers at what was then the great price of $£ 33$ per head. Practical tests such as these had a powerful effect. Among the bulls used by him were Satellite (1420) and Pilot (496), the former subsequently so valuable at Chilton. To $\mathrm{Mr}$ Wetherall he paid 250 gs. for St Leger (1414) and 500 gs. for three cows. His public sales were great events. Captain Barclay of Ury and Mr Alexander Hay Shethin were buyers at an important Phantassie sale held on 16th February 1827. The Captain then paid 105 gs. for Champion (865) by Pilot; 42 gs. for Rose by Satellite, and 53 gs. for Mursha by Leopold : Mr Hay's selection at 31 gs. was the white bull Jerry by Barmpton.

The Deuchrie herd, which was dispersed on 23rd April 1879, occupied a prominent position for about forty-five years. Mr James Tweedie, the founder, came from the Gala Water district in 1834 with a few Shorthorns. When the herd was sold off the bulk of the stock were descended from three cowsBeatrice Mayflower, bought from the Messrs Angus of Broomley in 1859; Twinness, a Warlaby purchase in 1862 ; and a member of Mr Maynard's Rose family, acquired at the Stokesley sale in 1863. Bulls of Booth blood were used. Windsor $(19,154)$, bred by the Prince Consort, came from the Royal Herd. He 
was followed by Mr Atkinson's well-known show bull Havelock $(19,928)$. Then came Prince of Warlaby $(20,593)$, out of 'Twinness. Booth's Clansman $(25,657)$, which was used five seasons; two of his sons, and such sires as Torr's Grand Herald (26,301); Lady Pigot's Job $(31,438)$, and British Grenadier $(33,217)$, followed. The herd had won numerous prizes, although handicapped by a high-lying situation. After $\mathrm{Mr}$ Tweedie's death the herd was conducted for a few years by his son, Mr James Tweedie. Prices at the sale were low. Mr James Currie, Halkerston, had the show cow, Rose of Tralee, at 57 gs., and $\mathrm{Mr}$ James How, Broughton, acquired the four-year-old British Grenadier at 68 gs. The average for 40 animals was $£ 2 \%$, 3s. $4 \mathrm{~d}$.

On the exposed Lothians farm of Halkerston, $\mathrm{Mr}$ James Currie founded, in 1856, a herd which came into high reputation. Mr Currie's abilities were recognised by such masters as the late Duke of Montrose, Viscount Strathallan, Mr Jas. Douglas, and Mr Donald Fisher. He placed main reliance on the old Gainford Raine blood, and liked to go into Northumberland for bulls, but he also selected from the Duke of Buccleuch, Sir Wm. Stirling-Maxwell, and Mr Thomas Marshall. The herd was sold on 21st April 1880. The leading price was 57 gs., paid by Mr Buchanan, Whitehouse, Stirling, for the Booth'-like four-year-old Rose of Tralee, which had cost the same figure at the Deuchrie dispersion a year previously. She had taken fourth place at the Perth Highland of 1879 . Cows were in very fair demand, 23 of them averaging $£ 35,12$ s. 2 d., 
but young calves reduced the average, which was $£ 26,14$ s. 6 d. for 50 head.

One of the ablest of breeders and most brilliant of exhibitors was Mr James Douglas, Athelstaneford. As a selector of coming animals in the showing sense, and of valuable specimens in the rough, he was probably unexcelled, He began his career as a Shorthorn breeder about 1842, and up to 1864 his exhibiting record was one of unparalleled distinction. A tenant farmer competing against Towneley, Warlaby, and other strong exhibitors, he was never daunted. At Mr La Touche's sale in Kildare he bought the fine Mantalini cow, Rose of Autumn, and she produced, at Athelstaneford, the wonderful Rose of Summer, which won the three National first prizes as a two-year-old, and first as a cow at the Paris Exhibition of 1856 , where her owner refused 600 gs. for her. To the buli Captain Balco, she bred Sir James the Rose, the sire of many beautiful heifers at Athelstaneford. Rose of Autumn had another noted daughter in Rose of Primrose, which was sold to Mr Mark Stewart, who afterwards disposed of her to Lady Pigot. $\mathrm{Mr}$ Douglas had a liking for the old Cherry blood of Colonel Cradock. From Mr Unthank of Netherscales he bought a heifer of old Cherry descent, and, following the Netherscales example, he named her Queen of Trumps, and she repeated Rose of Summer's exhibiting triumph. Looking abroad for a representative of the Fame family, he acquired one from $\mathrm{Mr}$ J. G. Grove in Donegal, and bred from her the remarkable Clarionet, which broke the winning career 
of Colonel Gunter's Duchess exhibits at Dumfries Highland, Having an intense admiration for the Killerby Bracelet line of breeding, he paid Colonel Towneley $500 \mathrm{gs}$. for Knight, which produced another great all-round winner in Maid of Athelstane and Queen of Athelstane, the latter being considered by Lady Pigot to be the nearest approach to perfection. Her ladyship paid $500 \mathrm{gs}$. for Queen, and had dreams of conquest, but the heifer died before the Leeds Royal came round.

Mr Douglas had wonderful honours at the Aberdeen Highland of 1858. He was first in cows with Ringlet; first and second in two-year-old heifers with Queen of Trumps and Venus de Medicis; and first, second, and third in yearling heifers with Titania, Luna, and Grand Sultana. At Warlaby, Mr Douglas bought Isabella Hopewell, a cow of mixed blood, as her dam was by Earl Spencer's Exquisite. To Mr Douglas she produced the famous bull Lamp of Lothian $(16,356)$.

The great bull, Second Duke of Cambridge, was out of a Bracelet-descended cow. He won the Gold Medal at Dublin, and, despite his composite blood, he proved a superb sire in Mr Talbot-Crosbie's herd. Mr Douglas's instinct in selection was balanced by his genius in mating. A Bates cow named Playful produced for him a number of winners, one of them being Pride of Athelstane, the Battersea Royal first prize exhibit. He made a cheap purchase at Killerby sale, in 1852, in the heifer calf Officious by Hopewell. Most of the Bracelet family are descended from that calf. 
Samples of Mr Douglas's artistic tastes can still be seen in and about Athelstaneford Mains farmhouse. The terraced frontage, sculptured flower-bowls at the garden entrance, with the heads of Rose of Summer, and Sir James the Rose, and other touches, reveal the worshipper of beauty. The noble-looking head of the famous bull is in stone also beneath the clock at the steading archway, and the stuffed head of his dam is aloft in the once neatly-decorated box where she breathed deep content after tedious journeys. $\mathrm{Mr}$ Douglas showed for the last time at the Stirling Highland of 1864. At that show he sold six of his best female animals to the Hon. David Christie, the Canadian breeder. By degrees he disposed of all his Shorthorns, and during the last few years of his life he kept commercial stock. He died on 10th February 1878. 


\section{CHAPTER VIII.}

Ainslie of Costerton-Whittingehame herd-Its founding-The modern herd and dispersion-Dalkeith Park herd-Composition and early successes-The sale-James Deans-Joseph Lee-His composite herd-Successful sale-Mark S. Stewart-His herd and frierdships -Dispersion sale.

The Costerton herd, owned by Mr David Ainslie, was of considerable repute. One of Mr Ainslie's best appearances as an exhibitor was at the Aberdeen Highland Show of 1868, where he won the firsts in the two-year-old and yearling heifer classes with Thistledown and Midsummer. Fair prices were received when the herd was sold in May 1869. Among the buyers were the Duke of Bucleuch, Sir Wm. Stirling-Maxwell, $\mathrm{Mr}$ Balfour of Whittingehame, $\mathrm{Mr}$ Brierley, Manchester, and $\mathrm{Mr}$ Bethune of Blebo. The top price was 70 gs., paid by Sir Wm. StirlingMaxwell for the two-year-old Henrietta, by Duke of Tyne. Mr Bethune's purchase at 46 gs. was Romping Girl, already referred to in connection with the notes on Blebo dispersion.

The Whittingehame herd was founded in 1857, when the owner, Mr Arthur James Balfour, was a minor, nine years of age. The herd came into prize- 
winning prominence at an early stage. At the Perth Show of the Highland Society in 1861, Mr Balfour led in the yearling bull class with Great Seal $(19,905)$. A bull of fame in after years stood second in Forth $(17,866)$, from Keir. Forth won the following year at Battersea, and Great Seal was placed third. At Kelso, in 1863, Mr Balfour led in the yearling heifer class with Lady Windsor. The late $\mathrm{Mr}$ Charles Smith, the Whittingehame agent, who laid the foundations of Mr Balfour's herd, and took general charge, until he was succeeded nearly twenty years ago by his son, Mr E. Hedley Smith, had been tenant of Hillhead Farm, Fort George, prior to 1852. $\mathrm{He}$ had a herd of Shorthorns which was sold off in 1860. The first Goldie cow was bred by him. She was bought by $\mathrm{Mr}$ Wm. S. Marr, Uppermill, and her dam Rubyhill was acquired at the same time by Mr Sylvester Campbell, Kinellar.

Mr Charles Smith's leanings were mainly towards the Booth type of Shorthorns, and his earlier purchases of females were from Shelbrook Park, Doncaster, and Broomley. Great Seal, which was bred at Hillhead, had for sire the Windsor Lord Privy Seal $(16,444)$. Prince Loth $(22,602)$, a son of Great Seal, was used at Whittingehame in 1864, along with the Alloa Red Friar $(24,913)$. Northern Light $(24,669)$, bred by the Duke of Montrose, was introduced in 1866. His principal successors were Merry Baron (34,838), bred by Lord Kinnaird; Sir George $(40,704)$, bred by $\mathrm{Mr}$ Hugh Aylmer; Crofton Prince $(55,524)$, bred by the Duke of Northumberland; the Leader $(66,428)$, from 
Collynie, and by Gravesend $(46,461)$; and Prince Superior $(79,660)$, from Barrelwell. Towards the end of Mr Charles Smith's life the Whittingehame herd had been reduced to very small proportions, and when Mr Hedley Smith took up the agency he resolved to strike out afresh on Cruickshank lines. At the Northern and other sales he gradually selected valuable females of the Clipper, Princess Royal, Goldie, Augusta, Queen of Rothes, Lavender, Broadhooks, Jilt, Lady Dorothy, Rosewood, Rosebud, Nonpareil, and other families. To these he put high-class bulls. Caliph $(85,514)$, a red Broadhooks by Victor of Sittyton (8071) from a Royal Star $(71,502)$ cow came from Lord Lovat; Proud Prince $(106,643)$, a red by Captain of the Mint $(94,565)$, was a selection from Millhills; then came Lancaster Crest $(116,162)$, bred by Mr John Marr and by Royal Leader $(103,727)$, and four Collynie bulls. These were Scottish Mint $(93,369)$, a roan by Scottish Fancy $(75,601)$; Proud Champion $(10,096)$, a very fine red roan by Pride of Avon (86,878); Primrose Star $(106,555)$, a beautiful white by Golden Primrose $(98,979)$, and the roan Roving Boy $(127,852)$, by Max of Cluny. Primrose Star took first at the Liverpool Royal, and second at the Dumfries Highland as a yearling, and Roving Boy was the winning two-year at the Manchester Royal of 1916.

At the dispersion of the Whittingehame herd on 31st August 1916, 68 head averaged £92, 6s. 5d. The average for 24 cows was $£ 89,10$ s. 7 d., and for nine two-year-old heifers it was $£ 142,18 \mathrm{~s}$. $4 \mathrm{~d}$. The 
top price of the sale was 370 gs., paid by Mr J. J. Moubray for the best-looking cow in the collection, the red five-year-old Goldie 32nd, a first-prize winner at the Edinburgh Show. A very fine roan heifer calf at her foot, sired by Proud Champion, was taken out at 100 gs., by Mr Peter Wilson, Mill of Gask. Goldie 33rd, a red with little white, half-sister to Mr Moubray's purchase, passed to Mr Casares, London, at $280 \mathrm{gs}$., and a Newton-bred Lavender fell to Captain Fletcher at 180 gs. For a red Nonpareil two-year-old heifer, Mr Thomas Kirk of Abbey Mains paid 200 gs. Out of the two-year-old group also $\mathrm{Mr}$ R. Wylie Hill took an Augusta at 170 gs., and $\mathrm{Mr}$ C. E. Gunther of Tongswood chose a Jilt at 250 gs. Mr D. H. Moore, the Ross-shire breeder, took Roving Boy at 220 gs. In this case the short pedigree was of course a selling handicap.

The Dalkeith Park herd, owned by the Dukes of Buccleuch, was founded in the early twenties of last century, and dispersed on 24th April 1908. It had a remarkably successful prize-winning career from about 1840 onwards for thirty years. Its oldest family was the Cherry, which had the same tap-root as the Broadhooks. The Ladykirk cow Short Tail, by Charles Colling's Cherry bull Wellington (679), was sold to the then Duke of Buccleuch. She was in calf to Mr Robertson's Albion (731) of the Dairymaid family. Short Tail's calf by Albion was Lady Derby, and her descendants were named the Cherries. At their best these were beautiful cattle, showing much family likeness, grand backs, wide ribs, and 
plenty of hair. The Rosebuds, or Primroses, came from Stanwick Park. Their foundress was a grandlooking cow, Passion Flower, acquired at Mr John Wood's sale, and by Mr Richard Booth's Cardigan $(12,556)$. She was in calf to Knight Errant $(18,154)$, a very fine Warlaby Moss Rose bull, and at Dalkeith she produced the famous red, Royal Errant $(22,780)$, which was so greatly admired when he won as a yearling and two-year-old at the Highland Shows of 1864-65. As a sire he proved the best ever used in the herd. Ruths of Northumberland descent, Apperly Princesses, Cressidas, and Ury Likelys were added on the fermale side. Among Royal Errant's successors were Lord Cecil $(26,621)$; the noted show bull The Earl $(27,623)$, bred by Mr Chaloner; Rosedale Favourite $(29,831)$, bred by the Rev. Mr Storer; the home-bred King Errant, a successful winner and impressive sire as he was much in-bred; Royal Hope $(32,392)$, of the Mantalini family; Solon $(47,135)$, from West Dereham, and such home-breds as Peacock $(45,319)$, by The Earl, and Baron Hope $(47,412)$, by Royal Hope, out of Corunna by The Earl. In its later years a few females were introduced from Orchardmains, Montrave, and Ratcheugh, and the young stock at the dispersion sale were by the dark roan three-year-old Lord Leith, bred by Mr James Durno, Jackstown, and by Royal Mint. Lord Leith had taken first at Perth in 1906. There he was bought for 280 gs. At the sale Mr Joseph Lee took him out at $110 \mathrm{gs}$. Prices in general were only fair, and, as the animals were in poor condition, 39 head 
averaged only $£ 21,13$ s. 2 d. Mr James Deans was manager at Dalkeith Park when the herd was over the crest of the wave, and he latterly saw it in the depths. Many will remember the worthy old mantall, spare, and with strength of character in his face. In judging a Border Leicester, he spread his capacious hand well over the animal's back and took a good grip.

One of the most breezy, unconventional, and warmhearted of men was Mr Joseph Lee, a native of the North of England, resident for sixteen years in the Lothians, for the first half of the period as tenant of Markle, and for the second as owner of Congalton. At Markle Mr Lee was a successful breeder of Border Leicester sheep. He kept the sheep going at Congalton, and once fairly settled down, he began to form a Shorthorn herd. Here he allowed his fancies free play with Scotch top-crossed Booths, a few blended Bates, and some excellent Cruickshank families. Had he lived another decade he might have conquered his diverse elements; but at his sale, on 18th September 1913, the stock looked somewhat mixed in character, and as the season had not been a good grazing one, the calves were thin. The top price of the disposal was 180 gs., paid by $\mathrm{Mr}$ J. J. Moubray for the two-year-old Clipper Pride bred by Mr John Gill. Mr A. J. Marshall had a cheap barren cow at 42 gs. in Congalton Augusta. A handsome three-year-old daughter of Mr Marshall's purchase fell to $\mathrm{Mr} \mathrm{Wm}$. Duthie at $130 \mathrm{gs}$. One of the oldest cows, Montrave Sorceress, was dam of Mr Lee's first- 
prize bull of 1910, Congalton Baron, which then drew $850 \mathrm{gs}$. At the dispersion eight two-year-old heifers reached the best average of $£ 41,12 \mathrm{~s}$. $1 \mathrm{~d}$. The general average for 122 herd was £28, 8s. 8d.

For a considerable term of years prior to 1864 , the Southwick herd, owned by the popular Dumfriesshire proprietor, Mr Mark S. Stewart, was well known. Mr Stewart was the first to bring Shorthorns into the Dumfries and Annan districts. If he had any leanings, it was towards the Booth cattle, but he made his selections from several sources, and was on the friendliest terms with such breeders as the Duke of Montrose, Lady Pigot, Mr James Douglas, Mr Samuel Bolden, and the Booths. In 1860 Mr Stewart sold off most of his cattle at fairly good prices, and on 7th October 1864 he disposed of all his Shorthorns. His cows of the Cherry and Rose families were the most popular, the latter strain being from Athelstaneford. There were fine cows by such sires as Sir James the Rose, M`Turk (14,872), Hudibras (10,339), Prince Imperial $(15,095)$, Grand Duke 3rd, and promising calves by First Fruits $(16,048)$. Mr Atherton of Chapel House paid the top price of 100 gs. for the roan heifer Southwick Cherry Flower, and he took the cow Southwick Cherry at 61 gs. Rose of Denmark was secured by Mr Johnston, Broadholm, at 49 gs. A few other animals ranged from 40 gs. to 60 gs., the latter price being for Eliza by M'Turk. The average for 47 cows and heifers was $£ 31,1$ s. 1 d., and for six bull calves, $£ 15,9$ s. 4 d. 


\section{CHAPTER IX.}

James Beattie, Newbie, and nephew-Founding of herd-Aylesby W's and Blooming Heathers-His sales-Visitors at Newbie-Thomas Marshall-Robertson of Ladykirk-His great work-Lord Polwarth -His appearance-Remarkable successes-Disappointing sale.

For well on to thirty years the Newbie House herd, owned by the highly characteristic Scot, Mr James Beattie, the lessee of the Solway fishings near Annan, had a national reputation. Mr Beattie, who became tenant of Newbie in 1845 , was at first a Galloway breeder, and a keen breeder and feeder of two or three varieties of sheep. In his mid-course he added pure-bred pigs to his collection, and in his own humorous terms he thus made the place a plague to the district. At the Paris International Show of 1856 he won the championship with the famous Galloway bull Mosstrooper, then eleven years old. Still, he considered the Galloways too slow. His old friend, Mr R. Syme of Redkirk, Gretna, had bred Shorthorns successfully away back beyond the middle of the century, and his nearest neighbour, Mr Thomas Marshall, Howes Farm, followed, and came into some fame. Why should the red-white-and-roan not have a trial at Newbie? Mr Beattie asked. 
The Galloways were cleared off Newbie by $18 \dot{6} 0$, and a few years later Shorthorns were gradually introduced. In the fifties $\mathrm{Mr}$ Beattie's general purpose young man was his nephew, Mr Simon Beattie, but when Simon was at the stake-nets or at Carlisle with a consignment of fish, his mind was always on the stock at the farm. Uncle and nephew came to "words" at last, and about 1858 the junior, who had previous introductions to the Millers and the Hon. M. H. Cochrane, set off for Canada, and began a striking international career, which lasted for thirty years. In $1861 \mathrm{Mr}$ Simon Beattie had his first transaction as an importer to America. He took out from Mr Syme's herd two bulls and four cows, the bulls and a couple of the cows being by Mr Unthank's General Havelock $(16,130)$. Of $\mathrm{Mr}$ Cochrane in the sixties, $\mathrm{Mr} \mathrm{Wm}$. Warfield noted: "He farmed largely, aided by that well-known character and excellent judge, Simon Beattie of Annan." In the Scottish sense, Beattie was more of an undisciplined genius than a "character."

Mr James Beattie took an early liking to the Aylesby W's, and in after years he had magnificent cows descended from Warrior's Plume and Wave Breast, both by the famous Breast Plate (19,337). Warrior's Plume, which was from Warrior's Pride, by $\operatorname{Dr}$ M'Hale $(15,887)$, cost 400 gs., in 1869 , as a three-year-old cow. She won at the Dumfries Highland in 1870, and at the Wolverhampton Royal in 1871. At the latter show she was described by the judges as "very sweet and feminine, with lovely head 
and fine quarters, short legs and good quality of flesh, but overdone with excessive feeding." The Newbie Shorthorns and general stock were under the charge of $\mathrm{Mr}$ David Beattie, a born judge and trainer, who was at times forced by his kindly but autocratic father "to do" the cattle too well. Mr Beattie's other families of cattle were descended from the Northallerton-bred Lady Booth by the Sutler $(23,061)$; Young Cherry, from Costerton; a Brilliant cow, from Southwick, and one or two purchases from the Messrs Angus of Broomley. $\mathrm{He}$ also acquired Seraphinas and other Booth strains not quite so well known. At the end of its career the W's and Blooming Heathers or Brilliants held pride of place in the herd.

Mr Beattie hired the finest bulls from Lady Pigot, the Messrs Booth, and Mr Wm. Torr. In the spring of 1876 Lady Pigot's Rapid Rhone was on short hire, and then passed on to Mertoun. His immediate successor at Newbie was the Killerby Titan $(35,805)$, by Merry Monarch $(22,349)$, out of Hecate, by Knight Errant $(18,154)$. On 8th September of the year just referred to most of the cattle were catalogued for sale. Best results were-Warrior's Pride, roan, five years old, by Bentinck $(28,016)$, out of Warrior's Plume, Mr Torr, 195 gs.; Warrior's Gem, roan, four years old, by British Crown (21,322), out of Warrior's Plume, Mr Torr, 260 gs. ; Lady Blithe, red, four years old, by Lord Blithe $(22,126)$, out of Lady Booth, $\mathrm{Mr}$ Burnyeat, Isle of Man, 180 gs. ; Wave Foam, roan, three years old, by Manfred (26,801), out of Wave Breast, Lord Polwarth, 170 gs.; Lady Knowlmere, 
roan, yearling, by Knight of Knowlmere 2nd (31,542), out of Lady Blithe, Rev. Thos. Staniforth, $250 \mathrm{gs}$. Lord Polwarth also took Wave Surf, a yearling, daughter of Wave Foam, at $115 \mathrm{gs}$. Demand for bulls was very slow. For 61 head the average was $£ 57,17 \mathrm{~s}$. 9d. By themselves, 47 cows and heifers averaged $£ 65,10$ s. 11d. A small herd was afterwards kept, and the dispersion came off on 4th April 1895, with an average of $£ 33,14 \mathrm{~s}$. Mr Beattie, who was a man of great physical and mental vigour, died on 2nd May of that season in his eighty-eighth year. His clever son, Mr David Beattie, who succeeded to the Newbie tenancy, died in December 1900.

During the seventies especially, Newbie was a hospitable centre for Shorthorn enthusiasts. Mr Thomas Easton, then at Storrs Hall, and Mr John Thornton, arrived together at times. The burly Cumbrian, $\mathrm{Mr}$ John Hope, afterwards so well known at Bow Park, Canada, was for years a frequent visitor, and $\mathrm{Mr}$ Andrew Mitchell, the strong man of Alloa, was an occasional guest. Tom Easton, the son of a Langholm parochial schoolmaster, was described by one who knew him in those days as a "bright funny man, with a mass of black curly hair and a turn for a half-comic song." His keen grey eyes had not then the passing films of the dreamy, which they assumed in his old age, when many a vision had vanished. With Shorthorns as text, Thornton and Easton were probably the finest discussionists in Britain.

Mr Thomas Marshall, to whom passing references have been made, bred Shorthorns for about thirty 
years at Howes Farm, quite near the burgh of Annan, on the Newbie side of the water. A strong-minded bachelor, highly respected in his district, he had a superior herd, largely of Booth blood. In his later years he sometimes threatened to "let the bull out" on Annan boys who were wont to take short cuts through his fields. Mr Marshall died in the spring of 1886, and his herd was sold off on 25th May of that year. The cattle were shown in quite good form, but it was a very dull period, and prices ruled low. Among the bulls used during the latter half of the herd's existence were Mr Banting (22,366), Bright Hope (28,081), Prince Arthur Patrick $(29,600)$, Prince Thomas $(35,183)$, Lord Derby $(34,524)$, Prince of Eden (46,902), and Marquis of Annandale $(58,022)$. At the sale $\mathrm{Mr}$ David Beattie, Newbie House, paid the top price of $34 \mathrm{gs}$. for Flora 5 th, a wide-backed roan cow by King Edward. He also took Red Grizzy 2 nd, by the same sire, with her heifer calf, at 25 gs. ; and Blooming Heather 2nd, whose dam had come from Newbie, at 20 gs. This Blooming Heather cow became one of the best breeders in Mr Beattie's herd. Mr Marshall's three-year-old roan bull, Kingscotte $(49,825)$, by King Edward, out of the same dam as Blooming Heather 2nd, was taken by $\mathrm{Mr}$ W. Bell, Todholes, at $35 \mathrm{gs}$.

More than Scotsmen are agreed that $\mathrm{Mr} \mathrm{Wm}$. Robertson of Ladykirk overtook work of enormous value as a Shorthorn pioneer. In 1789 he was, according to the testimony of $\mathrm{Mr}$ John Heriot, one of his favourite tenants, "a young gentleman of good 
fortune, enthusiastically attached to county affairs." Between 1789 and $1791 \mathrm{Mr}$ Robertson selected twentyfive of the best female animals from the herds of the Messrs Colling and Charge, and also two of their best bulls. Cows and heifers ranged from 20 to $50 \mathrm{gs.}$, and the bulls cost 40 gs. and 50 gs. For eight years afterwards Mr Robertson overdid in-breeding, according to the testimony of $\mathrm{Mr}$ Heriot, and the cattle became delicate. He had therefore to resort to an outcross. A glance at the list of bulls used by him in the early stages will show how close he went in his matings. In 1790 he used the Newton bullLadykirk (355)-bred by Charge, and by Dalton Duke (188) or Maynard's Bull, out of a cow owned by Charge. In 1791 he acquired the Lame Bull (357) from Charles Colling. That bull was by a son of Maynard's Bull, from the Charge cow. In 1794-95 a bull, referred to as Lady Maynard's bull (356), bred by Charles Colling, and by the Lame Bull (357), out of old Lady Margaret, the dam of Phœnix and Strawberry, was acquired. During 1795-97 a son of the Newton bull, out of a Hubback cow, was in use ; then came Punch (513) and a son of his, out of a dam by Lady Margaret's bull. From 1800 to 1805 he used Sultan (631), which was the son of Punch, out of a daughter of Strawberry. As a matter of course his cattle came to have a strong family resemblance, and when his bulls passed into pure-bred herds, somewhat unrelated in blood, they showed remarkable prepotency. In cross-bred herds they effected wonders. A year before his death $\mathrm{Mr}$ Robertson acquired the 
Pitcorthie-bred Sultan (1485), which was by Jupiter (1147), out of Phœnix, by North Star (458), the noted full brother to Comet (155).

$\mathrm{Mr}$ Robertson did excellent work as a breeder of Shorthorn steers, and in this way he won over many of the more intelligent of tenant farmers. He died in the spring of 1831, and his stock were sold on 16th and 17th May of that year. One of Mr Robertson's contemporaries in Berwickshire was $\mathrm{Mr}$ Abraham Wilson, Edington Mains, who had a good herd before 1820. Mr Wilson did much for the breed in a quiet manner, and he attracted to the Shorthorn cause capable men in the tenant-farmer ranks.

When at its best, from about 1885 to 1900 , the Mertoun herd, owned by Lord Polwarth, was in some respects unexcelled. Its cows were certainly a superb collection, true to their order in character, of grand scale, yet free from coarseness; and when they sauntered about the pastures, they showed that distinction which arrests and holds the attention of a breeder. Lord Polwarth began to make his selections in 1867, from the best herds in England and Scotland, his strong preference being for the Booth families. For a long time his lordship's distinctive Norse countenance, with its intense eagerness against a backing of analytic reserve, was familiar to all supporters of the Booth standard. In its midcareer the herd had representatives of the Farewell, Wave, Bright, Riby, Madaline, Gowan, Butterfly, Bracelet, and Medora families. The Aylesby-descended Waves he acquired from Newbie. Uppermill 
Missies were also introduced, but they had only a short trial. Among his famous bulls were the twice Royal winner Rapid Rhone (35,205), King David $(43,417)$, Royal Riby $(52,056)$, Sir Lucius Studley $(64,852)$, and Sir Cuthbert Studley $(64,838)$, the very finest of their order. Then two celebrated home-bred Wave bulls were used. These were the Windsor Royal champion Ironclad (55,913), a son of Wave Surf, and Windsor Royal $(62,041)$, the Highland Society and Royal Show champion; and they were followed by another home-bred in Royal Herald $(64,738)$, the Leicester Royal champion, and the Fifeshire-bred champion Nonsuch $(65,969)$, which provided an outcross for the herd.

His lordship's Waves had a wonderful showyard career. Apart from the Waves, his great prize-winning female was the red-and-white Truth, which showed rather more "daylight" under her than the Cruickshank men cared for. She was a daughter of Sir Arthur Irwin (44,016) and the Killerby-bred Timbrel, the latter a cheap purchase in 1886. At Plymouth Royal in 1890 Truth was first prize two-year-old, and the following year at Doncaster she was first and female champion, the first and second cows being Wave of Indiana and Wave of Loch Leven. Truth was again the female champion at Warwick Royal, her class follower being Wave of Loch Leven, the latter coming to the front at Chester in 1893. At Cambridge Royal, Bridal Robe by Crested Knight was first in her class and reserve champion. Towards the end of the century the best home-bred bull in the herd 
was the very neat White Border Riever $(68,254)$, a noted prize-winner by Sir Lucius Studley $(64,852)$. When the herd was sold off on 26th March 1912 most of its old glory had departed. Attempts had been made to hold it as much as possible to the order of other years and No Surrender! but Warlaby and Killerby were gone, and Cruickshank cattle were in command of the Shorthorn world. Low prices were consequently expected. But even as commercial stock, the cattle were absurdly cheap. $\mathrm{Mr} \mathrm{Wm}$. Duthie paid the top figure of $46 \mathrm{gs}$. for Wild Wave, a handsome two-year-old roan heifer, and the average for 64 animals was £22, 2 s. $4 \mathrm{~d}$. 


\section{CHAPTER X.}

The Bains' Legars-Brilliant showyard winnings-The sale-The Buchanans of Whitehouse-John Chrystal-Milne family-Dryhope and Faldonside cousins-Their herds and fancies-Miss Milne of Otterburn-Sir William Scott, Bart.-George Torrance-Tweedside and Border Societies-Founding and work-Border Union-Notable improvers.

For a quarter of a century the Legars herd, in the Kelso district, had a high reputation. Its prizewinning career was brilliant, and its general management by Mr Thos. Bain, the vigorous junior partner, was remarkably skilful. $\mathrm{Mr} \mathrm{Wm}$. Bain, the older brother, took quietly to the sheep department, but still he was fond of the cattle. Many will remember the kindly senior as he appeared in his later years: a gentle soul, with never a trace of old Border militancy, except in a dominant nose, which, however, was plainly contradicted by the soft light in the eyes and the benevolent curves about the mouth and chin. The herd was founded by the Messrs Bain's father, Mr Alexander Bain, in 1874, the first purchase being at Mr J. Dickinson's Maiden Hall sale. The cow then acquired was Grahamslaw 3rd, a descendant of Turncap Lily (vol. 10), which Mr Dickinson's uncle had bought at Magdalen Hall, 
St Boswells, about 1848, from the noted breeder, Mr George Grey of Millfield, who, like his father, owned grand cattle. Grahamslaw 3rd proved an excellent breeder, and produced Bessie Lee by Sir George Musgrave's Baronet $(30,443)$, and Annabel Lee by Lord Charles (34,503), a son of Mr Wood's famous Highland Society winner Royal Errant (22,790). Succeeding purchases were Charming Maid from Dryhope, Wild Rose from Edengrove, and Alexandra 3rd from Collynie-all good breeders. The Alexandra cow, which was by Lofty $(64,271)$, bred four first-prize bulls, including Handsome Boy, which was used for some time at Goldicote by $\mathrm{Mr}$ Jolliffe.

At the Floors Castle dispersion sale in 1880 the Messrs Bain selected their first stock bull. This was the noted Scothern Butterfly 2nd (40,678), which was used for several years at Legars. He proved a first-class sire, and rapidly brought the herd into prominence. He himself had taken first at the Yorkshire and Lincolnshire Shows of 1878 , third at the Bristol Royal, and the Medal at the Border Union. From 1886 onwards Cruickshank bulls were used by the Messrs Bain. Five in succession were from Collynie. Three of the Duthie bulls were of exceptional merit: Bright Boy $(60,403)$, a red by Gravesend, was out of the famous Bright Belle, the dam of Challenge Cup, Eastern Star, Brave Archer, and Bright Archer. Chivalrous (66,833), a roan Clipper, was by the champion Pride of Morning $(64,545)$, and his dam was by Sea King and grandam by Hercules. 
Earl Marshal $(76,343)$, a roan Missie, was by Scottish Archer $(59,893)$, his dam being by William of Orange and grandam by Athabasca. The last of a highclass succession of bulls was Principal of Dalmeny, a son of the White Sittyton Seal, which was first at the Edinburgh Highland. Between 1894 and 1904 the Legars herd won 10 firsts and 12 other awards at the Perth, Birmingham, Northumberland, and Border Union Shows. It was first at Perth in 1894-95, and first at Birmingham in 1904.

The Legars herd was dispersed on 17th May 1904. There was a good attendance, Ireland being very well represented. Among those present were Colonel Munro, Mr David Hume, Mr W. T. Malcolm, Mr Parkin-Moore, and the agents for Dalmeny, Mertoun, Naemoor, Whittingehame, Keir, Manderston, and Balcarres. The cows were fresh-looking, but somewhat thin. Prices were fair. The yearling heifers were a pretty lot. Mr Kirker, Belfast, paid the top price of $51 \mathrm{gs}$. for one of these, other good heifers being taken for Naemoor, Manderston, and Spotsmains. The 41 head sold averaged $£ 32,15 \mathrm{~s} .7 \mathrm{~d}$. A few female animals owned by Mr James Nisbet of Lambden were disposed of at the same time.

A well-bred little herd had been kept at Whitehouse, near Stirling, for a long time. The second owner of the herd, Mr Andrew C. Buchanan, the very capable and popular Secretary of the Stirling Agricultural Society, states that the herd was founded by his father, Mr Alexander Buchanan, over seventy years ago. The old gentleman held a distinct position 
in his district, as he had character, individuality, and resourcefulness. His principal strains at the outset were the Milkmaids and Beautys, the latter being from Argaty. One of the late Mr Buchanan's most notable cows, Rose of Tralee, will be remembered by old Highland Society Show attenders. She was afterwards sold to $\mathrm{Mr}$ Donald Maclennan, that king among exporters, and in after years he often stated that he had never sent a finer cow to the Argentine.

$\mathrm{Mr}$ Buchanan owned some very fine bulls. From Sir Wm. Stirling-Maxwell he bought a calf which became famous. That was Bywell (33,261), which won at the Highland as a yearling for Whitehouse. He had also the distinguished winners Star of Braithwaite $(48,785)$, bred by Mr Talbot-Crosbie, and Heatherbred Lad $(13,146)$, bred by Mr T. Lambert, Elrington Hall. "I will have the best if I can," was Mr Buchanan's guiding text in selection of bulls. As a matter of course he won many prizes at the county shows. One of the large championship cups for two bulls he won outright, and he also won, although not outright, every cup presented for Shorthorns at Stirling Show. During the last ten or twelve years only a few Strowan Cowslips and Uppermill Rachels had been kept at Whitehouse, and for about twenty years the herd had been getting the use of the Polmaise stock bulls. Mr Buchanan sold off his cattle in the autumn of 1919, and he gave up farming at the November term.

Mr John Chrystal, Dasherhead, Gargunnock, began to breed Shorthorns about the same time as the late 
Mr Alexander Buchanan, but for twenty years he had a larger herd than the Whitehouse one, and his cattle were not excelled by any collection in Stirlingshire. Over forty years ago Mr Chrystal removed to the county of Durham. Emperor, a bull of his breeding, appears in a good many well-known pedigrees.

Shorthorns were bred by the Milne family in the Scottish South-East since the early part of last century. Mr Milne, Dryhope, exhibited a cow by Sultan, and also a two-year-old heifer at the Border Agricultural Society Spring Show of 1815 ; and his son, Mr Nicol Milne, who followed him at Dryhope in the late thirties, had a noted herd which was dispersed in May 1879. Mr Nicol Milne, on setting out for himself about 1836, bought a cow from Mr James Chrisp, Doddington, Wooler. His leanings were towards cattle with a dash of Bates blood in them, but he was free from prejudices. Mr Milne rarely attended a Shorthorn sale. He studied the catalogues, and if he knew the breeders he made a short leet and got Mr John Thornton, or some other trusty friend, to select a bull for him. He sold his own young bulls privately, for the most part to farmers in the counties of Peebles and Selkirk, and the animals gave great satisfaction. Among the sires used by him in later years were Viscount Stanley $(23,152)$, Oxford Cherry (24,709), Grand Knight (26,302), and Freebooter (19,789). Mr Milne died in 1878, and his cattle were sold at the displenishing sale in May of the following year. Mr John Muir, who then took up the tenancy, bought several of the best female animals and kept 
a very good little herd until his own outgoing in 1896.

Mr Nicol Milne, Faldonside, Melrose, a cousin of the Dryhope tenant, was known further afield. Both were bachelors and of distinct individuality. Lord Polwarth has recorded that he never met "Faldonside's" superior in knowledge of Shorthorn cattle. As an adviser, this strong old type of a tenant farmer was absolutely reliable. The Faldonside tenant began to found a herd about 1836. His first purchase of any consequence was the cow Prendwick Princess (vol. vii.) from $\mathrm{Mr}$ Chrisp. In vol. 19 of the HerdBook there appear Ruby, a red by MacRufus ; Princess, a roan by Abbotsford; Prowler's Princess, a red and white by Prowler; and Prince Regent's Rosebud, a roan by Prince Regent. The Dryhope and Faldonside herds were of somewhat similar composition during the early stages, but they struck out on rather different lines ere very long. In the mid-seventies of last century Miss Milne of Otterburn acquired some cows from her Faldonside brother, and for a period of about fifteen years she won many prizes at the Kelso bull shows. Bulls and heifers bred by Miss Milne sold remarkably well in the Border district. She had only two families of Shorthorns, the Faldonside Princess and the Burnside Marchioness. Favourite bulls at Faldonside were MacRufus $(24,501)$, Prowler $(22,662)$, Abbotsford $(23,266)$, and Prince Regent $(29,676)$. Miss Milne owed much to her talented brother. The blood of Abbotsford and Prince Regent proved specially valuable to her. 
In the eighties of last century Sir Wm. M. Scott, Bart., of Ancrum, near Jedburgh, had a choice little herd of Booth cattle, consisting of the Killerby Mantalini, Mistress Mary, and Red Rosette families, and the Blebo Strawberry. The roan Mantalini cow, Lady Bright, by Mr Thos. C. Booth's Bright Baronet $(37,891)$ came from Mr George Allen, County Down, as also did the roan Welcome Lady by Irish Hero (36,791). He was indebted to Mr Hugh Aylmer and Mr David Pugh, Manoravon, for his Mistress Mary family. Mr White's Mistress Mildred, bred at West Dereham Abbey, was by High Sheriff (26,392), a son of Commander-in-Chief $(21,451)$, the Royal winner of of 1868 . Then the roan Marchioness Towy $4 \mathrm{th}$, bred by Mr Pugh, was by Mr Aylmer's Sir Charles $(44,020)$. Put to Lord Polwarth's Lord Marmion (53,174), Marchioness Towy 4 th bred the roan Marchioness of Lothian; while Mistress Mildred, mated with the same sire, bred the roan Mistress Muriel. The Red Rosettes came from the herd of Mr L. C. Chrisp, the purchases being Stanhope Rose by Fitz-Roland $(33,936)$ and Village Rose by Fine Prince (44,809). Mr Bethune's Strawberry 32nd, a light roan, fifth in descent from Romping Girl, had for sire the Alloa Prior (46,930). She founded at Ancrum a small family named after her. The Strawberry line traced back to the Kendal district, where Mr Luke Ellison bred Mary by Umpire (5530). Sir Wm. Stirling-Maxwell, Bart., the Duke of Montrose, and Mr David Ainslie had representatives of this strain of breeding.

Sir Walter Thorburn, M.P., had a very good herd 
at Orchardmains, in the Peebles district. It was founded in 1889 with Red Rose of Langton 2nd, bought at the dispersion of the Hon. R. BaillieHamilton's stock. Red Rose proved an excellent breeder at Orchardmains. Sir Walter made other purchases from the Duke of Buccleuch, Mr Muir, Dryhope, and Mr Ingram, Middleton of Troup, Banffshire. At the sale of the herd, which took place on 7 th May 1902, a good many of the cows catalogued were by Edgar $(67,002)$ and his sire Bell-the-Cat $(60,354)$, a full brother to Cock of the North $(57,072)$, the Highland Society champion of 1891. Others were by the Craigwillie Magistrate $(74,971)$. The best bull latterly in use was the Balnakyle March On $(79,357)$. He was by Fortune $(70,467)$, out of Marchioness 15 th by Merlin (54,715). The principal buyers at the Orchardmains sale were the Duke of Buccleuch, Sir John Gilmour, Bart., and Messrs David Hume, Joseph Lee, James Fenwick, A. M. Law (who got away cheaply with a Red Rose), and J. T. M'Laren, then at Polmaise. Mr Hume took Orphan, a roan heifer calf by March On, at 44 gs.; Mr Fenwick secured for Mr Maxtone Graham Lady Maud with red bull calf by March On at 48 gs.; Sir John Gilmour paid 50 gs. for Fannie, a roan cow with roan bull calf at foot by Banker; Blooming Heather with red heifer calf by March On fell at 40 gs. to Mr Elliot, Hollybush; Mr Fenwick next took the roan Lily 7 th and her like-coloured bull calf by March On at 52 gs.; Captain Graham Stirling had about the best of the younger cows in Lady Gertrude with roan bull calf 
by Banker, price 41 gs. ; Sir John Gilmour had the best of the yearling heifers in Lady Dorothy 3rd, roan, at 35 gs., and Bell Heather, roan, at 37 gs. For 57 head the average was $£ 27,7$ s. The stock were very well shown by Mr James Murray, the manager, who was then engaged by the Duke of Buccleuch.

Between 1879 and 1889 the late Hon. R. Baillie-Hamilton had a fine herd of Bates cattle at Langton, near Duns. The herd was coming to its best when a dispersion sale was rendered necessary on account of the owner's failing health. The sale was held at Melrose on the Wednesday of the Highland Society Show week, Mr John Thornton being the auctioneer. Mr John H. Laurie, Mr BaillieHamilton's skilful manager, afterwards so well known in Border Leicester circles, states that the foundation purchases were from Sir W. C. Trevelyan's herd. Of that lot Oxford Cherry 2nd and Emma 10th were remarkably fine animals. Red Rose of Illinois, from Dunmore, was not only a beautiful cow, she was a grand breeder. The descendants of her second calf, Rose of Langton 2nd, were conspicuous in the Orchardmains herd in after years. The substantial Waterloo cow, Duchess of Wellington 6th, was bought at Mr Oliver's Sholebrooke Lodge sale. Her best bull calf was acquired by a Belgian breeder. At the Duke of Devonshire's sale in 1883 a couple of Oxford cows were secured, and at the same time two Wild Eyes cows were bought from Mr Starkie. The principal bulls used were Lord Cockburn $(38,594)$, 
Oxford Duke of Killhow $(48,399)$, and Duke of Saxony $(51,149)$. Most of the young bulls bred in the herd were sold locally, and they greatly improved the stocks of the district.

At the dispersion sale prices were considered satisfactory for the time. For 46 animals the sum realised was $1896 \frac{1}{2}$ gs. Thirty cows averaged $44 \frac{1}{2}$ gs., 5 bulls 59 gs., 5 bull calves 36 gs., and 6 young heifer calves 15 gs. Best prices were-Red Rose of Langton, Lord Polwarth, 40 gs. ; Red Rose of Langton 2nd, Mr (afterwards Sir Walter) Thorburn, M.P., 31 gs. ; Waterloo Witch 2nd, Mr Deacon, 45 gs.; Winsome Bright Eyes, Mr Laing, 87 gs.; Oxford Grand Duchess, Mr Ackroyd Carlisle, 92 gs.; Red Rose of Langton 10th, Mr Fletcher, 40 gs.; Waterloo Witch 5th, Mr Fletcher, 70 gs.; Oxford Grand Duchess 2nd, Mr Harris, Calthwaite, 155 gs.; Oxford Grand Duchess 3rd, Mr Harris, 110 gs. In bulls, the best price was 105 gs., paid by Mr A. W. Lloyd, Surrey, for Duke of Waterloo 11th; Oxford Grand Duke passed to $\mathrm{Mr}$ H. Sharpley, Lincoln, at $81 \mathrm{gss}$; Colonel Hutton paid 65 gs. for Duke of Saxony. Among other buyers were Lord Brougham; Major Conway, North Wales; Mr James Watt, Carlisle; Mr George Torrance, Sisterpath; and Mr Peterkin, Dunglass.

$\mathrm{Mr}$ George Torrance made a considerable impression on his contemporaries while he held the farm of Sisterpath, near Marchmont Station, Berwickshire. $\mathrm{He}$ was a very good judge of a Shorthorn, but he sometimes neglected registration work. Mr Torrance left Sisterpath in 1888 and removed to Leetside, 
Chirnside, where he died in 1899. His principal families of cattle latterly were the Cherrys, tracing back to a cow by Simon (5133); the much betterknown Rosebuds, descended from Premium by Leopold (2199); the Didos or Emeralds, full of Booth blood; the Jewels, going back to Kitty by Waterloo (2816); and the Empresses, tracing to Likely by The Pacha (7612). Cherry Shoot (49,268), a bull of $\mathrm{Mr}$ Torrance's breeding, appears in the Bates-crossed Orange Blossom pedigree. Among the bulls used at Sisterpath were Major $(43,607)$, roan, bred by Lord Polwarth from a dam of Uppermill Missie descent; British Grenadier (33,217), red and white, bred by Mr J. Bowman from a cow by Baron Killerby $(23,364)$; Lowland Chief $(48,269)$, red, bred at Legars and by Scothern Butterfly 2nd $(40,678)$; First Lord (46,355), red, bred by the Hon. R. Baillie-Hamilton; and Oxford Duke of Killhow 4th $(48,399)$, roan, bred by Mr S. P. Foster, and used for some time by Mr BaillieHamilton.

Modern breeders in the Border district are more deeply indebted than the majority of them know to the enterprising and far-sighted men who formed the Tweedside Agricultural Society in 1811 and the Border Society in 1813. The latter organisation, which was set agoing with a publicly subscribed sum of 300 guineas, had as first president the Duke of Roxburghe. Its opening show was held at Kelso on 15th September 1813, and thereafter Spring and Autumn Shows were conducted and premiums were awarded for the best Shorthorn bulls, draught and 
clean-legged stallions, Leicester and Cheviot rams, also boars; and prizes were given for other classes of stock, including butchers' animals. In 1817, Mr Wm. Robertson of Ladykirk suggested that the Border Society should adopt the hiring principle in connection with cattle improvements, while still holding by the premium system. His suggestion received full support, and through Mr Matthew Culley of Akeld, a Shorthorn bull, "for the use of the Society," was hired from Mr Christopher Mason of Chilton at $60 \mathrm{gs.}$, and the animal was sent north in the spring of 1818 " under the charge of a careful person." In 1820 , the two Societies "formed a junction" under the name of the Union Society, and in modern times the title of "Border Union" was adopted as being more definite. At one of the early meetings of the Border Society, Mr John Grey of Millfield, afterwards of Dilston, referred to the cattle in the district as being of no breed, but as combining the bad points of several breeds, "covering with a thick hide large bones on which it was almost impossible to lay fat." It is probable that he referred specially to West Berwickshire. At the Border Society Spring Show of 1814 , the first premium of $£ 42$ for a Shorthorn bull was won by Mr Thomas Smith, Grindon, and the second, of $£ 31,10$ s., by $\mathrm{Mr}$ Matthew Culley. Mr Smith was also first at the shows of the two following years. After the joining of the two Societies, premiums for Shorthorn bulls were gradually increased. At the Autumn Show of 1832, for instance, the first premium, of 50 sovereigns, was won by $\mathrm{Mr}$ 
Hogarth, Haymount, for his white bull, bred by the late Mr Robertson of Ladykirk; and the second premium, of 40 sovereigns, by Mr Dudgeon, Spylaw, "for his bull." Among premium winners for bulls between 1833 and 1843 were Mr James Chrisp, Doddington; Mr Smith, Grindon ; Mr Smith, Shedlaw; Mr Hogarth; Mr Carnegie, Edrom; Mr Bell, Linton; Mr Hunt, Thornington; Mr Elliott, Lamberton; Mr Jopling, Castlelaw; Mr Jobson, Turvielaws; and Mr John Grey. Mr Grey's bull, which won the first premium at the Union Show in the spring of 1843 , took leading position a few months afterwards at the Dundee Show of the Highland Society. Kelso and Coldstream were the show centres for the Union Society. 'A View of some of the Transactions of the Border Agricultural Society and of the Union Agricultural Society; from 1813 to 1843 , by $\mathrm{Mr}$ George Jerdan, the Secretary (Kelso, 1844), is very interesting. 
$-5$

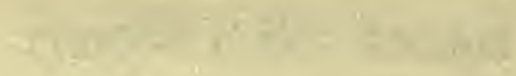

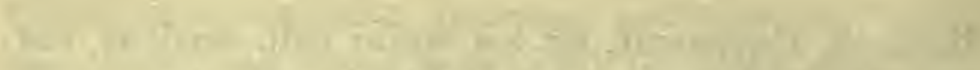

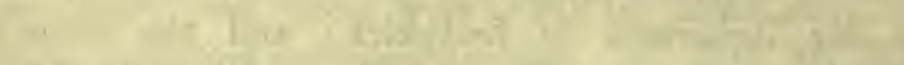

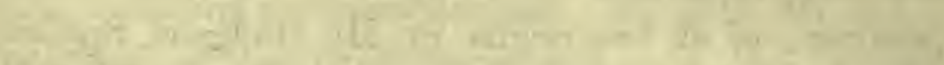

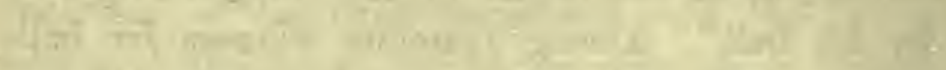

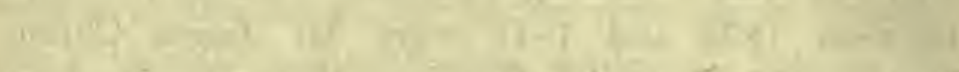

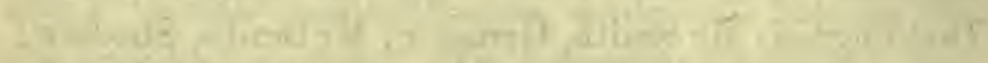

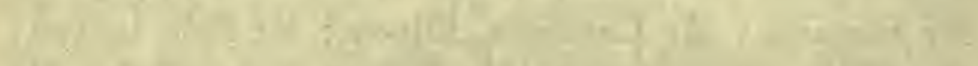

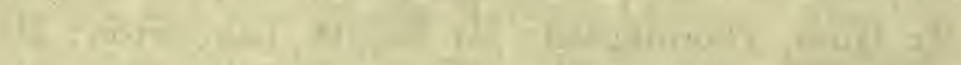

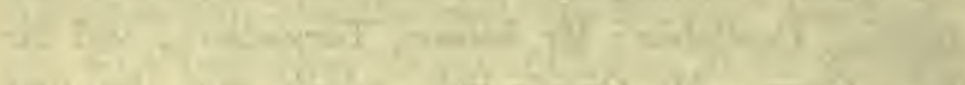

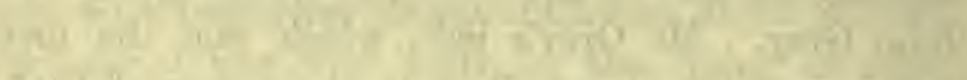

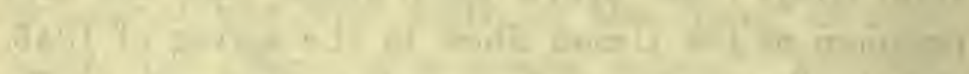

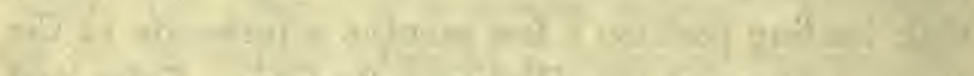

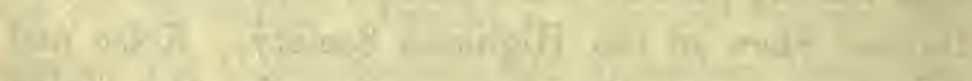

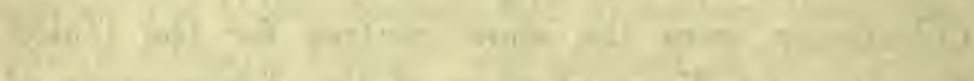

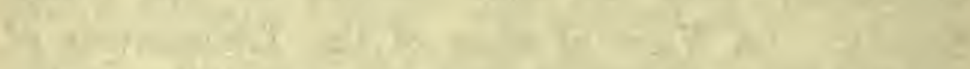

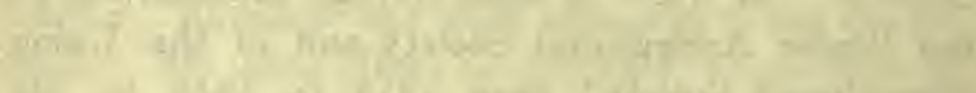

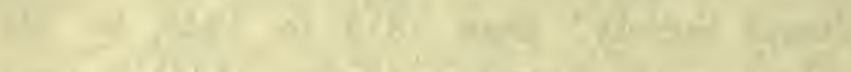

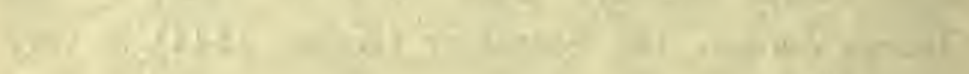
$+1$ 


\section{HERD NOTICES.}

\section{Abbey Mains.}

ThE large and fine-lying farm of Abbey Mains, nearly three miles to the east of Haddington, has its house and homestead on a gentle eminence a field-breadth away from the public road, and the residence, one of the substantial old order, with a few guardian trees, looks squarely to the south. Most of the land has a gentle fall towards the sun; enclosures are regular and spacious; the farm has excellent stone dykes and hedges, while water supplies are of the best. Mr Thomas Kirk, who has been occupying owner of the farm since 1914, came to the Lothians in 1913, and took up the Abbey Mains tenancy. He had been farming on arable and pastoral lines at Hyndhope, in the Selkirk district, and there he had bred some Shorthorns since 1910. At Abbey Mains his initial handicap as a tenant, with aspirations towards a first-class herd, was the old-fashioned steading. When he became owner, he laid his plans for a thorough renovation and extension of buildings - a slow and costly business 
in war-time-but his enterprise and energy were rewarded in due time.

Mr Kirk's first selections of Shorthorns in 1910 were at Little Haddo sale, Aberdeenshire. There he took out of the ring Butterfly 67 th by Royal Prince $(93,268)$, and the red Charlotte Corday yearling, Merry Maid 5th, by the same sire. Passing on to Loanhead, he bought Duchess 29th, a roan yearling by the Saphock-bred Lancelot $(99,338)$. $\mathrm{He}$ added no animal of special consequence until 1912, when at Mr Salvin's Burnhall sale he acquired Tulip 2nd, a showy roan yearling of the old Ballechin Carnation family and by the prize-winning Burnhall Marquis (104,935). This heifer has proved a very good breeder. Two years ago a heifer calf out of her was exported at 300 gs. to the La Concordia Estancia. Attending the Mertoun dispersion sale, Mr Kirk took two cows-the six-year-old red Wave of Tweedside by Red Ensign $(93,035)$, and the fouryear-old roan Madeline Maid, a member of the Towneley Butterfly family by Lord Remenham (92,340). A handsome daughter of the older cow is the roan Wave of Tyneside by Findon Rosebank $(108,620)$. The younger cow has had twins twice. Somerset Waterloo, a roan by Diamond Fancy $(94,875)$, was a selection at the Congalton sale. In 1915 the Abbey Mains breeder took a beautiful Broadhooks yearling from Mr Gordon Oswald's lot. Sired by Boquhan Standard Bearer (114,409), this female produced the Perth third-prize bull at the 1916 show, the red Abbey Mains Dictator $(134,494)$, 
now a highly-prized sire in the herd of Mr P. B. M'Intyre, Findon Mains. An excellent addition was made to the Abbey Mains herd in the same year in the red Scotch Dorothy, a heifer calf bred by $\mathrm{Mr}$ D. D. Williamson, Auldtown of Carnousie, and the Saphock - bred Proud Barrister $(117,100)$. The Whittingehame sale gave Mr Kirk a fine selective opportunity, and his fancy there swayed to a pretty roan Princess Royal heifer calf by Edgcote Sceptre $(120,101)$, and breeding like twoyear-old red Nonpareil in calf to the noted show bull Roving Boy $(127,852)$. As a two-year-old the Princess Royal produced a very fine heifer calf by Mr G. B. Shields' Esmond's Heir, a Lancaster bull exported in 1917. The Nonpareil started with the red Abbey Mains Advance Guard, which was sold at Perth for 220 gs.

At Aberdeen a few weeks later, Mr Kirk added from Hillhead of Ellon a fine yearling in the roan Lancaster Charm, by the noted Lothian Laird $(112,374)$, and a dark roan Champion of England Butterfly heifer calf from Durno House and by Nonpareil Star $(121,793)$. The principal purchases in 1917 were Ballechin Duchess, a roan heifer by the great stock bull Royal Leader $(103,727)$; a thick short-legged red, Uppermill Bessie, from Mr Young, Cadboll; Hawthorn Bloom 21st, a prettily-moulded roan heifer calf from $\mathrm{Mr}$ Ingram, Middleton of Troup, and with Auchnacree Whyte $(118,644)$ as sire; and Clipper Gem, a grand roan calf from Hillhead, and by Lothian Laird. Those were important additions. 
From Mr Whittome in $1918 \mathrm{Mr}$ Kirk bought one of the finest representatives of the Keir and Cambushinnie Groat family. That was the four-year-old roan Waterloo's Groat, a sweet-headed, wide-ribbed, low-set cow by Lord Waterloo (116,340), a fine bull of Mr Wylie Hill's breeding. In the autumn he acquired a handsome Broadhooks yearling and a very good Lady Dorothy cow, both reds. These were Cullisse Lady Zona by Sanquhar Union Jack (122,751), and Mounteagle Dewdrop by Balnakyle Channel Stane $(107,754)$. Some beautiful heifers of the Rosebud, Miss Ramsden, and Eliza families were the principal selections afterwards. The first-named is by the Collynie Sittyton Yet $(133,632)$, while the last noted, which was bred at Throsk, had for sire Collynie Golden Boy $(130,288)$. Mr Kirk's more important recent additions to his herd have been a Meg Merrilies and an Augusta from Linksfield, and a Princess Royal of superb breeding from North Loirston. The last noted cost $700 \mathrm{gs}$.

The most striking bull in appearance ever owned by $\mathrm{Mr}$ Kirk is the massive red five-year-old Sanquhar Knight Marshal $(133,424)$. Between the ages of two and three, very few grander-looking bulls could be seen anywhere. Of the Duchess of Connaught family, he is by Collynie Grand Knight $(119,549)$, and his grandmother was by another notable Duthie bull, Scottish Crown (79,915). Knight Marshal has been of most value as a heifer-getter. At a previous stage Mr Kirk had used the red Throsk Monarch $(123,265)$, a Marigold bull by Doune Bondsman 
$(115,098)$. The Abbey Mains breeder secured an exceptionally well-bred bull, and a real Cruickshank, at the Perth sale of 1918 . That was the roan Cluny Augustus 2nd by President of the Mint (109,670), out of the Royal Northern first-prize winner Cluny Augusta 4th by Edgar 2nd of Cluny $(91,611)$. Cluny Augustus 2nd was full brother to Lady Cathcart's first-prize winner of 1917 , and their mother was grandmother of Cluny Sir Augustus, the first-prize winner in the January class of 1918, for which $\mathrm{Mr}$ Maconochie paid 2000 gs. Mr Kirk kept his Cluny bull only one season. He won with him at Perth in two-year-olds, and sold him for 530 gs. At the Perth sale of last year he acquired at 400 gs. the blocky-framed dark-red roan Aldie Mac, an almost full brother to Captain Macgillivray's reserve champion Aldie Armistice. "Mac" might have been kept for another season at least; as a son of Millhills Rothes King $(138,020)$ he had the backing of a great sire, but an exporting offer was too tempting, and so he passed over the water. On the outlook for a firstclass white bull, the owner of Abbey Mains secured last spring a short-legged beauty at $1800 \mathrm{gs}$. in Mr Ralph S. M'William's January class-second prizewinner Stoneytoun Challenger by Redgorton Earl $(244,805)$, and of old Shethin Mysie descent on the side of his dam.

\section{Ardargie.}

As Ardargie Mains, now farmed by the proprietor, Mr John J. Calder, and Nether Ardargie, tenanted 
by Mr Thos. M'Intosh, have had a number of crosstransactions in Shorthorns, they may be dealt with under one heading. The late Mr James Calder, father of the present proprietor, may be said to have started to breed Shorthorns at Ardargie Mains. At Colonel Munro's sale in 1905 he acquired, at 93 gs., the Shethin Mysie heifer calf Lady Grandtully, by the Newton-bred Pillar Stone $(84,311)$, a son of the champion Cornerstone. Recent additions to the Ardargie Mains herd have in part been from Mr M'Intosh. The transfers from Nether Ardargie have included two Broadhooks, a Myrtle, and three Orange Blossoms. The oldest Broadhooks is a deepframed, handsome roan cow, bred by Mr Gordon Oswald of Aigas, and by Merry Challenger 2nd $(99,622)$. At foot she had in 1919 an excellent roan bull calf by Doune Bright Star, a bull from the same dam as Mr Wm. A. Dron's 1500 gs. Doune Majestic. While in Mr M'Intosh's possession the Broadhooks cow produced Broadhooks Queen Maud, a pretty red heifer by Master Pye 2nd (116,503), a Royal winner as a two-year-old. That heifer is now owned by Mr Calder. Mr M'Intosh bred the Myrtle. She is a sweet red five-year-old out of a Westerton purchase, and her sire was the Darlington first-prize bull Baron Bridekirk 49th (118,816). She also had a shapely bull calf by Doune Bright Star. The Orange Blossom, red in colour and eleventh of her line, was bought by Mr M'Intosh from Mr H. R. Macrae of Clunes. Her sire was Gartly Rosedale (102,309). A red Doune Bright Star bull calf at her foot looks 
promising. Orange Blossom 12th, a fine roan fiveyear-old, bred by Mr M'Intosh from the 11th, is by Baron Bridekirk 49th. There is great breeding and promise in her bull calf by the Doune Lodge stock bull Eclipse of Collynie. Orange Blossom 15th, a roan yearling out of the $12 \mathrm{th}$, should develop into a beautiful cow. Bred by Mr M'Intosh and passed on to Mr Calder, her sire was Master Pye 2nd.

Important purchases made at Aberdeen for the Ardargie Mains herd have been a roan yearling Secret, of splendid substance, acquired from $\mathrm{Mr}$ Robert Copland at 450 gs., and Lavender Wreath, a pretty red heifer bred by Capt. Fletcher of Saltoun, and costing 230 gs. The Secret is by Knight Errant $(126,349)$ from a dam by Primrose Archer $(106,551)$, and the Lavender is by Burgomaster $(124,576)$ out of a dam by Proud Champion $(100,096)$. There could not be better breeding. $\mathrm{Mr}$ Calder has laid an admirable foundation. At the Cullisse dispersion sale Mr Calder secured a very fine roan bull calf in Cullisse Cluny of the Secret family, and by the Crieffvechter Economist $(136,346)$, a grandson of Cupbearer of Collynie $(114,960)$. Cullisse Cluny's dam was acquired by the Duke of Portland at $550 \mathrm{gs}$.

Ardargie Mains is an extensive high-lying Perthshire Ochils farm, with outcrops of whin-rock in parts, but with slopes of very good cropping land. Sections of the farm are steep and somewhat difficult to work, but it has a reputation as a healthy place for stock.

At Nether Ardargie, which is rather lower-lying and nearer the Forgandenny side, Mr M'Intosh has 
bounds for only a small herd, as his noted flock of Border Leicester sheep required the main part of the moderate-sized holding until recently. Old Lady Grandtully, wonderfully fresh for her years, ended her days last autumn on the farm. Her young companions and successors represent the Orange Blossom, Bellona, Brawith Bud, Broadhooks, and Myrtle families. The Orange Blossom is a red yearling by Master Pye 2nd out of Orange Blossom 11th; a young Bellona cow is a very fine Boquhan-bred red by Kingston of Edgcote $(131,776)$ from a dam by Golden Primrose $(98,979)$, and Briar Bud 14th, bred by Mr Robert Anderson, Fingask House, is by Hean Clarence (125,971), dam by Primrose Archer (106,551). The Broadhooks is a show heifer, a grandly-balanced roan by Master Pye 2nd out of the old Aigas-bred cow now at Ardargie Mains. In the case of the Myrtle, a very pretty red home-bred cow by Keir Raider $(102,645)$, the character of the family with which Mr James Durno has won so much distinction is well maintained. This cow has a beautiful red heifer calf by Dunglass Chieftain. At the North Loirston sale the enterprising tenant of Nether Ardargie paid 700 gs. for the yearling heifer Princess Royal Beauty 5th by Collynie Master Lavender (141,710).

With such materials $\mathrm{Mr}$ M'Intosh might soon work into a first-rate herd, if more space were at his command. He has a stock-breeder's instincts and long experience. 
Arngask.

"What's in will out." By heredity and early training Mr Wm. Constable Hunter, W.S., has taken naturally to farming and stock-breeding. His father, the late Mr Patrick Hunter, one of the ablest agriculturists in Central Scotland, long tenant of Ardgaith in the western section of the Carse of Gowrie, and latterly owner of Waterybutts, Inchture, was a son of Mr Charles Hunter, who took up the tenancy of Ardgaith in 1828. In the historic section of this volume reference is made to the owner of Lochton, and the tenants of Monorgan and Glencarse. $\mathrm{Mr}$ Charles Hunter married a daughter of Mr Patrick Kinnear of Lochton. The Ardgaith man's brother, $\mathrm{Mr}$ James Hunter, was tenant of Monorgan, and the two had an enterprising cousin in $\mathrm{Mr}$ Hunter, Glencarse. The Glencarse tenant further was an uncle of Mr Kinnear. Through his mother, also, Mr Wm. C. Hunter comes of a Carse and district farming race. On his picturesquely-set property of Arngask he is still in his ancestral Perthshire, but his back is very near the Kingdom of Fife, when he looks from his residence through rifts in a crosswise half-avenue of trees towards the setting sun. The old Tulliallan herdsman would describe Arngask as being "on a skelf be itself jist an' lookin' feckly Wast." The foreground falls somewhat sharply to the railway, beyond which is the village of Glenfarg, almost completely hidden in a shaded clearance. On the 
far side of the village the landscape, with its blocks of timber and water-worn scoops, rises into rounded knolls and curving uplands, which block the view to the Southern Grampians. The best portion by far of Mr Hunter's 120 -acres property is on the top and with a slight dip towards the east. Otherwise, there are burning spots near the whinstone should a season prove unusually droughty.

Mr Hunter set out on his course as a regular Shorthorn breeder in 1909 by acquiring from the Earl of Moray a representative of the highly successful Meg Merrilies family by Diamond Earl $(98,591)$. She bred remarkably well at Arngask. Two excellent young cows out of her were sold in 1918 to Mr Ieslie Smith for export to the States, and they averaged $£ 300$ each in the West. The old cow's family is now kept in a fairly safe position in Mr Hunter's herd by a couple of thoroughly typical females. In 1912 an Emmeline and a Miss Ramsden were bought for Arngask from the late Sir James Sivewright and the Messrs Kerr, Lochlane, Crieff. The Emmeline, which was own sister to one of the best-breeding cows at Tulliallan, proved a sound investment. The Miss Ramsden, which was by the famous Millhills stock bull Collynie Cruickshank, was out of the same dam as the heifer which founded one of the best families at Balthayock. From his Miss Ramsden Mr Hunter has bred female animals which have distinguished themselves in the herds of Mr Wylie Hill, Mr Thos. Kirk of Abbey Mains, and $\mathrm{Mr}$ Peter Wilson, Lawhill. One of her sons, Ramsden 
Rufus, was successfully used two seasons by Mr George R. Grant, Auchnacree, and she has two handsome daughters still at Arngask. So highly did Mr Hunter think of this branch of the Miss Ramsdens that he acquired from Capt. Macgillivray, then of Aldie, Dolly Ramsden, a blood-red cow of great substance. Her red roan two-year-old heifer by Millhills Rothes King $(138,020)$ is one of the best animals at Arngask.

At the Dunballoch sale in 1916 he took out a couple of red daughters of Alice Broadhooks, the highest-priced cow. Those reds have so far bred three heifers and two bulls at Arngask. One of the heifers and a granddaughter of the old Emmeline cow have gone to lay the foundation of $\mathrm{Mr}$ George Brudenell's herd at Deene Park, Peterborough. Another of the young Broadhooks has passed on to Mr James Piper's herd at The Grange, Burntisland. This strain of Broadhooks has the cross of the famous Royal Star $(71,502)$, which was such a success at Beaufort. In 1916 also $\mathrm{Mr}$ Hunter added to his herd Cairncosh Jilt 6th, uterine sister of Mr Cazalet's great prize-winner, and Queen Mysie 5th (vol. 62, page 957), this being a member of the noted old Shethin family, and with a cross of Star of Morning $(58,189)$. Owing to overcrowding those two cows were sold at Birmingham in 1918, but pretty heifer calves out of them were retained. More recent additions have been Gunthorpe Secret 2nd, a deepframed granddaughter of Mr John Marr's Royal Leader $(103,737)$; Highfields Butterfly of the Beatrice branch with the Champion of England cross; the 
massive old Clipper cow Esther 6th from Dalmeny and dam of Mr George Harrison's Crewe champion Lothian Clipper Duke; Rosewood 89th (vol. 64), a dark roan from Mr Murray, Old Manse; Moresby Goldie, bred by Mrs Burnyeat, and out of Collynie Goldie 2nd (vol. 60), and Rosemount Lady Sarah (vol. 64) from $\mathrm{Mr}$ Robert Geekie of Rosemount, Blairgowrie. The Lady Sarah is a well-grown, beautifully-proportioned roan heifer by Magnetic Star $(126,714)$. She is thirteenth in descent from Rosie Annie, which the late Mr Alexander Geekie of Baldowrie bought from Capt. Barclay of Ury.

The first bull used by Mr Hunter was Sunstar $(117,944)$, bred by the late Sir James Sivewright, and full-brother to King George, the Perth firstprize winner of 1911 , but one year younger. He was exported too soon. The white Evening Star $(115,331)$, a Lustre bull bred by $\mathrm{Mr}$ Connon, Nether Coullie, and by the Highland Society champion, Gartly Landseer, followed, and left stock with very good hindquarters. Then came the dark roan Polmaise Quiver (127,324), a Jenny Lind by Proud Massa $(109,776)$. He was in Major Murray's Reserve group at Perth. Shortly afterwards the red Orange Blossom bull Shaddock $(128,126)$ by Edgcote Watson $(111,692)$, out of Sweet Orange by Strowan $(107,206)$, was bought from Mr Wylie Hill. Like Sunstar, this bull was parted with at too early a stage. He left high-class stock of beautiful colours. In 1916 two young bulls were bought. These were Cluny Count Florian $(130,251)$, a short-legged son of the famous 
President of the Mint $(109,670)$, and the roan Eliza Alexander $(123,848)$, bred by the Earl of Rosebery at Mentmore, and from the same dam as the Royal English reserve champion Elegance. So far as he was tested the Cluny bull proved a thorough success. He was sold to fill a special order for the Argentine. Partial use was made in 1918 of the home-bred light roan Lexicon of the Lovat Julia or Dairymaid family, and by Lex of Cluny. He was then exported by Mr Leslie Smith, and drew a high price at auction in the States. Alexander, now over six years old, was recently sold to Mr James Murray. Always smooth and mellow-fleshed, easily kept and perfect in temper, he has been a fine breeder. A high-class yearling was acquired last season in Pellipar Jehu (vol. 65), a rich roan of Colonel Ogilby's breeding, by Edgcote Regalia $(125,396)$, out of Luxury 40 th by Count Crystal (108,276), Regalia being by Collynie Regal King from a dam by King Christian of Denmark. As a show bull Pellipar Jehu is easily the best bull ever owned by $\mathrm{Mr}$ Hunter. Linksfield Model, the beautiful dark roan bull calf which was acquired at Colonel Johnston's dispersion sale, is very promising. $\mathrm{He}$ is by the 3000 -gs. Lothian Mario $(137,713)$ out of a Mary of Argyle cow.

The owner of Arngask sometimes finds his field space too limited. His general aim plays around 40 to 50 head of Shorthorns, but the latter total is often exceeded-one more proof that numerical exactions must make way at times before enthusiasm and a great breed's fascination! 


\section{AUCHNACREE.}

Mr George R. Grant's property of Auchnacree in North-East Forfarshire, within twelve miles of the county town and seven miles from Brechin, is one of the highest-lying farms in Britain held by Shorthorns. The main part of the steading, which is on a brae-face shelf with a very abrupt background, comes partly into view as one works round the elbow of a somewhat stiff approach, and the bull-boxes appear on a higher plateau. At the first level the buildings are at an altitude of quite 700 feet, and the arable land ranges up to fully 900 feet. Immediately beyond is the heather. The ploughable land extends to about 80 acres, and the hill ground to 420 acres. For all its elevation it is a fairly kindly place, with a southern exposure, some woodland shelter from the north, and a pleasant summer and autumn range along the lower fields, which are still further protected from the colder winds by irregular masses of mixed timber. Most of the soil is a loam of very good quality and fair strength. Grass is somewhat late in appearing, as one might expect, but it holds on well through the autumn. The young stock look their very best before passing into their airy wintering quarters.

A business man, with a love for country life and a red-white-and-roan, Mr Grant set out as a Shorthorn breeder fully twenty years ago. His earliest purchase was a Butterfly from Balnakyle. That was at the Munlochy joint sale in October 1899. A 
Shethin Lovely from Cluny Castle, another Butterfly from the late Sir H. H. Smiley, a Groat from Pitcur, a Dairymaid from Westside, a Jilt from Huntingtower, a Lancaster from Doune Lodge, a Strowan Baroness from Balthayock, and a Broadhooks from Keir followed. The herd of cows is kept about a score, and of that number the majority are now descendants of the Butterfly and Lovely purchases. Butterfly 31st, a beautiful roan heifer calf bred by the late Mr C. M. Cameron, was by the Uppermill Fortune $(70,467)$, and her dam was by the Sittyton Merlin (54,715), which proved such a good breeder of females at Balnakyle. Lovely Lady 3rd, bred by Lady Cathcart and bought as a calf in 1903, was a compact, short-legged red by Clan Macdonald $(78,597)$, her dam being by the Collynie Goldspur $(64,107)$. Bounty 2 nd, a good-framed red roan cow, was bought at the Perth draft sale of Sir H. H. Smiley's stock in 1905. Her sire was the Pirriesmill-bred Candahar $(78,522)$, and her dam was by the Uppermill Reginald $(64,654)$. Mr Grant has now in females over one year old eight descendants of Butterfly 31st, three from Bounty 2nd, and six from Lovely Lady. The Balnakyle branch of the Butterfly family is run into a Moth line at Auchnacree, while the Smiley branch is switched into the Bat track. The total stock on the farm usually run from 35 to 40 head.

Auchnacree Moth 8th, a roan out of Butterfly 31st, Auchnacree Lottie, a red out of Lovely Lady 3rd, and Auchnacree Bat 2nd, a roan from Bounty 2nd, 
are beautiful cows by Strowan Butterfly 24 th (104,110), which ended his days in the Corston herd. Those cows and other females by the Strowan bull have charming heads with slightly down-curving flat horns. Lottie is dam of Auchnacree Laird, the second-prize bull in the two-year-old class at Perth in 1918, and highest-prized animal in his section. Mysie Groat, the purchase at Pitcur, was by the Collynie Count Nicholas $(76,435)$, the grandsire of Earl Manvers, Royal English Champion, Duke of Kingston 2nd. A red daughter of the Groat cow by the Strowan sire is one of the finest-looking females in the collection, and her young bull by Auchnacree Rajah (134,744) was accounted the best in Mr Grant's lot at the Perth spring sale of 1919. Although the Jilt was acquired from Messrs Lumsden \& M'Kenzie, she was bred at Pitcur. Her sire was the Uppermill King Victor (81,394). A red daughter is easily picked out as by the Strowan bull.

With regard to the principal bulls used by $\mathrm{Mr}$ Grant, March On $(89,231)$, a handsomely-proportioned roan bred by Messrs Lumsden \& M'Kenzie, and by the noted breeder Prince Fortinbras $(79,618)$, did remarkably well, especially as sire of heifers. Royal Duke $(96,890)$, a dark roan son of Royal Banner $(87,152)$, from Dunglass Ruby 2 nd by the champion Collynie Conqueror $(78,609)$, proved generally satisfactory. Strowan Butterfly 24th, already referred to, was used seven years at Auchnacree and four years at Corston. Sired by Congalton Conqueror $(88,236)$, and from a Montrave Baron $(81,740)$ cow, 
grandam by Dauntless 4 th $(62,369)$, he was a striking success. He was sire of Auchnacree Mogul, the Perth first-prize bull in the younger class, 1912, and his stock were always popular. Nigel of Cluny (116,747), a very thick-set, short-legged roan, acquired at the Perth sale of 1913 for 220 gs., was used with great effect for four years, and then sold to $\mathrm{Mr} \mathrm{W}$. Scott Clyne, Wick. He was by Edgar 2nd of Cluny $(91,611)$ out of Cluny Flora 103rd by Mr James Durno's Diamond Fashion (94,877). He was sire of Auchnacree Laird 2nd, and of Auchnacree Moth 15th, the latter being the highest-priced heifer calf at the Aberdeen October sale of 1915. The Arngask-bred Ramsden Rufus, a red of choice quality, was bought in 1917 , but he was exported after a comparatively short trial. The present stock bull is the home-bred Auchnacree Rajah, a blocky-bodied roan by Nigel of Cluny out of Auchnacree Moth, the dam of Auchnacree Mogul. Mr Grant's herd is a most interesting one. It demonstrates what the Scotch Shorthorn can do even when placed near the heather.

\section{BALCARRES.}

Shorthorns have been bred by the Earl of Crawford and Balcarres at his home farm near Colinsburgh since 1904. The late Mr George R. Fortune, then estate agent, began by taking out at the Legars sale the roan cow Sunset and her heifer calf Sunbeam. Thereafter he made purchases of a Lady Dorothy and a Kirklevington from Rosehaugh, Dairsie Mains- 
bred Fortuna females from Mr George Russell of Hatton, three heifers of the Wimple family, and a Queen of Spey from the Duke of Richmond, and a red heifer calf, Montrave Agatha, of Knightley Anna descent, from Sir John Gilmour, Bart. Of all these, only the Wimple and the Montrave purchases are now represented in the herd. The first of the Clippers was the red-and-white Eve bred by Mr George Anderson, West Fingask, and by Golden Victor (91,978). This is the Newton branch of the Clippers which became so well known at Montrave. A Jealousy from Newton, a Sanquhar Graceful from the late Mr Alexander Robertson, Ballechin, a Graceful from Polmaise, a Marigold from Keir, and a Waterloo from $\mathrm{Mr}$ James Morrison, Phingask, were added by $\mathrm{Mr}$ Fortune, but these females have no descendants in the existing herd.

The oldest cow now in the herd is Augusta 120th, bred by Colonel Munro at Mains of Murthly, and by Edwin of Ballechin $(95,070)$. She has six female descendants of great merit in the herd, the oldest being Augusta 121st, a very handsome roan by the Heatherwick Scottish Gift $(110,102)$. Clippers make a fine show at Balcarres. One of the best is the seven-year-old Pink Lady by Scottish Gift out of Eve. Another first-class cow out of the original purchase is the white six-year-old Esther 10th, also by Scottish Gift. A four-year-old white, a three-yearold red, and a two-year-old roan, granddaughters of Eve, maintain the high character of the family. The only member of the Wimple family now in the herd 
is Lady Anna, a home-bred eleven-year-old out of the Gordon Castle Lady Evelyn Hope.

Montrave Agatha was the dam of Juliana, a great cow recently sent to the butcher. Juliana was dam of the noted show cow Lady Margaret, by Scottish Gift, and of the roan yearling. Balcarres Juliet, by the Uppermill Premier (132,759). Then out of Lady Margaret herself there are the three-year-old Marguerita, by the Saphock Royal Marksman, the twoyear-old Lady Marjory, and the yearling Gretta, by Premier. What magnificent cattle the females of the family are, with their aristocratic-looking heads, splendid scale, and swaggering carriage!

Two members of the Broadhooks family are in the herd. These are Duchess Broadhooks 16th; bred at Throsk, and by Doune Raider $(108,419)$, and a pretty yearling daughter by Premier. Over a generation ago the Beaufort Undines were much admired. Balcarres Undine by Premier is the only one of her line in the Earl of Crawford's herd. She is out of Lady Jane Undine 2nd, a purchase from Mr C. M. Bruce, Burgie Lodge. A very fine group of the Butterfly family can be seen on the farm. Auchnacree Moth 10th and Auchnacree Moth 14th, bred by Mr George R. Grant, and by Nigel of Cluny $(116,747)$, out of dams by Strowan Butterfly 24th $(104,110)$, form a picture with their sweet heads and compact blocky frames on short legs. A pretty red yearling by Premier out of the 14th is to be retained in the herd. A Heatherwick Mayflower, bought as a calf at the Aberdeen October sales of 1916, rounds off 
the principal families in the herd, which has so far been kept to a breeding total of about twelve cows.

Two of the best bulls used in the herd have been the Heatherwick Mayflower Scottish Gift by Spicy Gift $(110,737)$, and Ivo of Cluny $(99,211)$, acquired from Mr Wylie Hill. During the 1919 season use was made of the red two-year-old Doune Reservist, a very finely-bred member of the Rachel family by Doune Grand Knight $(130,657)$, and with the crosses of Proud Warrior (106,653), Diamond Earl $(98,591)$, Marquis $(84,061)$, and Captain of the Guard $(58,586)$, on the female side. From $\mathrm{Mr}$ Wm. A. Dron, $\mathrm{Mr}$ Gilbert R. M'Garva, the agent, recently bought the short-legged red roan Broadhooks bull King of Diamonds $(137,377)$. That bull should suit the herd very well.

Balcarres home farm has an extent of fully 520 acres. On the north it is sheltered by abrupt, partly tree-clad steeps of rugged trap. Fields of fine-cropping loamy soil over trap or whin fall away gently from the steading towards the Firth of Forth. It is land on which stock thrive and grow. The Shorthorn handicap hitherto has been the old-fashioned bullockfeeding steading. Such grand cattle are worthy of the best accommodation. The most pressing necessity is a range of boxes for young bulls and special animals.

\section{BaLdowrie and Rosemount.}

From the late thirties of last century on through the forties and early fifties, Mr Alexander Geekie of 
Baldowrie, in the Newtyle district of Forfarshire, was a man of distinction as breeder and exhibitor of Shorthorns. No records are available as to when he founded his herd, but his earlier purchases were probably made between 1830 and 1834. In volume 4 of Coates' Herd-Book his name appears with six entries. The white home-bred bull Sir Robert, calved in 1839, was by the Ury Emperor (3716), and his dam was bred by John Grey. Then there were George, another white, by The Baron (5420), out of the Ury cow Jane; Paul Pry, by The Baron; a Lady Sarah cow, called Ruby; and Stanley, by The Baron, out of the Barclay-bred Diana. At Captain Barclay's sale, in 1838, Mr Geekie bought Rosebud; Ruby, a granddaughter of the famous Chilton Lady Sarah; and an unnamed yearling heifer, by Emperor (3716), out of Cecily. Ruby cost 78 gs., and the yearling went to $50 \mathrm{gs}$. There can be little doubt that the heifer was Rosie Annie, the daughter of Cecily, and granddaughter of Lady Sarah. Whatever experiments Mr Geekie may have tried at the outset, he soon settled down to Ury blood on the female side. By 1840, if not earlier, his leading families were the Lady Sarahs and the Snows, Carolines, and Lilys of Ury descent, and with the cross of Monarch (4495).

As owner of several farms, Mr Alexander Geekie led an active and useful life, and no man was more highly esteemed in public affairs. An early manhood portrait of him shows a singularly handsome face, a head with a rich dower of dark auburn hair, and a well-set-up figure. Over all, one has an impression 
of kindly alertness, thoughtfulness, and individuality. Here was a man of personal charm and of inward strength. His herd was gradually dispersed between 1870 and 1875 , and he died in 1889. The more notable of Mr Geekie's early-life successes were at the Inverness Highland of 1839, where he won with "Best two Heifers of the Improved Shorthorned Breed," and at the Dundee Highland of 1843 , where he took the award for "Best Bull of the Pure Shorthorned Breed." His family are naturally proud of pieces of plate recording those old-time victories.

Mr Robert Geekie, brother of Mr Alexander Geekie, owned and farmed Rosemount, near Blairgowrie. The Rosemount man was what one might term a good commercial farmer. He took an interest in the Baldowrie cattle, and followed their prize-winning course with some zest, but his main inclinations were towards the feeding of stock and the growing of ordinary crops. He died in 1871, and his heir was his namesake, Mr Robert Geekie, son of Mr Alexander Geekie. The junior was farming in the Carse of Gowrie when his childless Rosemount uncle died. The young man shifted to Rosemount in 1872, and shortly afterwards he acquired specimens of his father's favourite Snows, Lilys, Carolines, and Lady Sarahs. To these he had held ever since. Rosemount is consequently the only existing link with old Ury. Mr Robert Geekie's cattle form a class by themselves. $\mathrm{He}$ had beautiful cows in his lot of about twelve, and all were good milkers, as hand-milking and rearing of calves by the pail were adopted by him over thirty 
years ago. In the late seventies and early eighties, when the calves were suckled, the young bulls from Rosemount made a great appearance as a rule, but since that time they have not been seen to advantage around the yearling stage.

In its 500 acres Rosemount has about 100 acres of shingly, normally thirsty land, which might have suited Andrew Fairservice's parish of Dreepdaily, but the main portion of the farm is "real able," as John, the farm-manager, puts it, and he should know, as he was born on the farm, and has been on the place as boy and man all his life.

On a beautiful plateau, with wonderful views to mountain-ranges and outpost summits, fine banks of land, as the natives term them, fall away very gently from the homestead, and the owner may be said to have neighbourly touch with the Stormont and fair Strathmore. The farm buildings were intended to endure. One sees no sign of scamped mason-work in them. Mr Geekie, a retiring but genial and keenly observant man with a sense of Scots humour, had not gone much from home during the last twenty years. Were he inclined to be fanciful he might have said-

"'Tis pleasant through the loopholes of retreat

To peep at such a world; to see the stir Of the great Babel, and not feel the crowd."

From his father's and his own garnering he had notes grave and gay relating to Barclay, Hugh Watson, and other strong men who ran their course between the Mearns and Central Scotland. In a sense he was 
removed from "endless agitation," and still a sharer in the hum and throb of life. Mr Geekie died on 9th August.

\section{BALLECHIN.}

After Mr Alexander Robertson's death the desirable stock farm, Haugh of Ballechin, in beautiful Strathtay, was leased by $\mathrm{Mr}$ Wm. Rose, a native of Morayshire, who wished to have breaks from a business life in Glasgow. Acting on sound advice, Mr Rose resolved to keep the farm to its Shorthorn associations. At the dispersion sale held by Mr Robertson's representatives the new tenant bought a couple of Uppermill Rachel heifers by Scottish Chieftain $(97,047)$ and Tom Bowling $(97,441)$. The following spring he acquired at Perth the second-prize two-year-old heifer Duchess of Strathtay, bred by Mr Alexander Cameron, and by Tom Bowling. That heifer, which was of Mr Robertson's favourite Carnation family, developed into a very handsome cow, and she bred several excellent bulls. Three of these, Ballechin Crown, Ballechin Corporal, and Ballechin Cardinal, were exported to South America. Corporal was champion at Penrith as a two-year-old.

The Shethin Mysie heifer Rose of Balcarres, one of Mr Rose's early purchases, and sired by Bold Bailie $(90,943)$, out of Colonel Munro's Rose of Grandtully, by Pillar Stone $(84,311)$, proved a great breeder. One of her daughters, Ballechin Mysie, by Ringmaster $(109,913)$, was dam of the massive red bull Ballechin Mutineer (134,798), which was exported as a two- 
year-old at 700 gs. Ballechin Mysie was also the dam of Ballechin Magnet, the very handsome red second-prize bull in this season's March class at Perth. He was sold to $\mathrm{Mr}$ Paton, Gorthy, Perthshire, for 700 gs. From Corston Lancaster, a blocky roan heifer of $\mathrm{Mr}$ Buttar's breeding, and by Royal Goldie (103,704), several good heifers and bulls were bred. Sunbeam 10th, acquired from Mr James M'William, became dam of Ballechin Senator (118,702), a third-prize winner at the Perth Spring Show of 1914. By far the most fortunate of Mr Rose's purchases were those which he made at the Lessendrum dispersion sale. There he selected the heifers Rosewood 82nd, by Brave Augustus (107,996); Prudent Maid, a Broadhooks, by Mr J. A. Horn's Royal Leader $(113,173)$; Roan Bessie, of the Uppermill family, by the same sire; and Roan Dorothy, by Manchuria $(92,428)$. Those heifers have proved high-class breeders. The best daughter of Rosewood 82nd from a show point of view has been Ballechin Rosewood, by Cupbearer of Collynie (114,960), but a great deal could be said from a breeder's point of view in favour of Ballechin Rosewood 4th, now in the Rachan herd. The Lady Dorothy has produced a highly distinguished-looking daughter in Royal Dorothy, by the Uppermill Royal Leader. Prudent Maid has been a bull breeder. Her best son has been Ballechin Brigadier, a high-priced bull in the Argentine. In addition to the foregoing families, Mr Rose has tried a Minmore Duchess of Connaught, by Royal Vanguard (103,767), a Newton Jenny Lind, by Brilliant 
Star $(76,240)$, an Uppermill Marigold, by Prince Palatine $(117,061)$, and a Kilblean Beauty, by Gartly Landsman $(125,670)$, from Mr James Kemp, Auchencrieve.

At the earlier stages Mr Rose's best bull was the Millhills-bred Cruickshank's Favourite $(114,941)$, by Collynie Cruickshank $(136,003)$. Rather unfortunately for the herd that bull was exported after one season's use. The herd benefited immensely a few years ago from the use for nearly three seasons of the great Uppermill Royal Leader (103,727). His heifers were of remarkable merit, and they have proved splendid breeders. The neat red Collynie Golden Baron (125,733), of the Rosalie family, and by Royal Crown $(117,292)$, bred very well, especially during his last two seasons. Golden Dorothy, a beautiful roan yearling heifer, by him, out of Fair Dorothy, by Cruickshank's Favourite, was sold at the Aberdeen sale of 1919 for 630 gs. Ballechin Major, a very tastefully moulded son of Golden Baron and Ballechin Mysie, was a prominent prize-winner in the possession of $\mathrm{Mr}$ Alexander Cameron of Cookstown during season 1919, and at the fall he was sold for $£ 2000$. Only a limited use was made of the exported Lethentybred Pride of Rosewood $(144,524)$, by Boquhan Pride $(111,114)$. The handsome Uppermill Chief General $(141,557)$ - the highest-priced calf at Mr Durno's sale in 1917-bred remarkably well. Lady Dorothy and Rosewood, heifer calves by him, were sold at the Aberdeen sale for 230 and 420 gs., the latter being taken by Captain Macgillivray. Chief General was 
by Collynie Chief $(114,765)$, and his great-grandmother was the Bellona cow which bred the worldfamous champion and stock bull, Choice Goods.

\section{Balmanno.}

Brilliant successes with Hackneys and Welsh ponies have not been quite enough for $\mathrm{Mr}$ Wm. S. Miller of Balmanno Castle, Bridge of Earn. He has set out on his spacious home-farm as a breeder of Shorthorns, and it may be predicted with confidence that his aim will be the front rank. The pleasant slopes above the stiff low-lying reaches of Lower Strathearn should suit his purpose admirably. Meanwhile, he is subjecting the old feeding steading to a complete overhauling in order to make it a proper winter home for a breeding herd. Under existing conditions such renovations and extensions consume a considerable portion of time.

Since 1916 Mr Miller has bought a few first-class female animals of the very finest breeding. These are of the Secret, Pure Gold or Brawith Bud, Nonpareil, Broadhooks, and old Garne Pye families. The Secret, calved in 1915, and the Brawith Bud, a year younger, are reds, bred by the Right Hon. Frederick Wrench, and are by the famous Linksfield Red Baron $(112,982)$, one of the best breeding bulls sent from Scotland to Ireland in recent years. The dams of both cows were by Albert Zenith $(101,234)$, bred at the Agricultural College. In the case of the Secret, the grandmother was by the Collynie Violet's Fame $(78,078)$, the next cross being that of Silver Plate 
$(75,633)$, and the pedigree works down to Commodore, Cumberland, Roan Gauntlet, and Pride of the Isles. The grandam of Golden Gladys, the Brawith Bud cow, was by Mr Jolliffe's Primrose Earl $(89,641)$, under which are the crosses of the Collynie-bred Count Lavender $(60,545)$, by far the grandest stock bull ever used by Mr Deane Willis, and the Sittytonbred Feudal Chief $(51,251)$, the sire of Dauntless $(54,155)$, a bull second to none in Perthshire Shorthorn history.

Rose Nonpareil, a dark roan, bred by Mr Duthie, was bought as a calf at the October sale of 1916 . She is by the Millhills Clipper Star $(124,786)$, her dam being by Roscommon $(93,173)$, and the pedigree passes down through Abbotsford $(69,838)$ to the great bulls Royal James $(54,972)$ and Gravesend $(46,461)$. The Broadhooks, a roan bred by the Edgcote Shorthorn Company in September 1915, had for sire the noted red Ascott Clipper $(107,666)$, the Birmingham second-prize bull of his time, and her dam was the high-priced cow Broadhooks Queen by Spicy King $(75,717)$, grandam by Lord Lynedoch $(74,900)$, which had a world-wide reputation in the Jackstown herd. Gainford Laurel 2nd, a roan calved in 1916, was bred, as her name indicates, by $\mathrm{Mr}$ George Harrison. Her sire was that remarkable breeder and successful show bull, Collynie Mandarin (119,552), her dam being a well-known prize-winner by the Manvers White Emperor (101,104). That cow also produced Gainford Emperor, which was sold in the Argentine by Messrs Casares \& Sons for $£ 3060$. 
Some promising young stock by Mr A. J. Marshall's Broadhooks Diamond (124,530), now in $\mathrm{Mr} \mathrm{Wm}$. M'Allister's herd, and Bridgebank Orangeman, were to be seen at Balmanno in 1918-19. Orangeman was a roan Orange Blossom by the Collynie White Knight $(128,848)$.

\section{Balmerino.}

Balmerino, with its remains of a once magnificent Cistercian abbey, its associations with a stirring period in Scottish history, and its ties with an unfortunate seventeenth-century nobleman, has attractions for the student. The farm, which has an extent of about 300 acres, is mainly on the volcanic rock which has a considerable basis in North Fife. With the exception of a small portion, the dip is towards the north, with an outlook to the Firth of Tay and Dundee. Some of the fields are fairly steep, but there is "bone" in the soil. The lower-lying enclosures are well sheltered by plantations and hedges. Mr James Murray, the tenant, who had early training in Aberdeen-Angus cattle, began to form a herd of Shorthorns in the autumn of 1911.

From Mr Stephen Mitchell he then acquired the seven-year-old roan Lady Dorothy 39th by the Collynie Golden Prospect $(81,181)$. She produced a roan heifer calf in December to Collynie Cupbearer $(105,069)$, and in 1913 she bred a red heifer calf to the noted Proud Warrior (106,653). This red was sold at Perth as a yearling, but the roan was retained and she bred excellent females. In 1916 and 1919 
she had twins. From Mr E. Moubray Alexander, Newbiggin, Mr Murray bought, in 1916, a red Brawith Bud by Lothian Watchman $(116,358)$ out of a dam by Collynie Marshal $(105,071)$, which was so effectively used at Dunglass and Edgcote. So far she has bred two bull calves, her second being a handsome red by the Doune Lodge stock bull Eclipse of Collynie (136,344). He also bought from Mr Alexander a red West Fingask-bred Orange Blossom by the highlysuccessful Strowan $(107,206)$. Her calf of 1917 was a very pretty red heifer by the Perth reserve champion Doune Grand Knight (130,657), and she followed with a handsome roan bull calf by Dunglass Brilliant. In the same year Mr Murray selected a finely-bred Clara by Edgar 6th of Cluny $(120,071)$ from Polmaise, and she produced a beautiful dark roan heifer calf by Boquhan Cavalier, a roan son of Collynie King Royal $(114,768)$ from Sensation 14th by Earl of Elgin $(91,589)$.

The only purchase in 1917 was the red Brawith Bud, Aven Bud, bred by the late Mr John Watson, Kirkwood House, Strathaven, and by Edgar of Millhills (115,256). At the Aberdeen October sale of $1918 \mathrm{Mr}$ Murray added a couple of choicely-bred heifer calves-a white Eliza by Merry Victor $(116,563)$ from Tulliallan, and a red Myrtle by Bessbrook (124,300) from Butchercote. Uppermill Goldies are having a great set-off in the herd. In $1919 \mathrm{Mr}$ Murray bought from Mr Wm. Meiklem, Begg, Kirkcaldy, the old red Goldie 36 th by the Boquhan Lavender Monarch $(99,348)$ dam Goldie 30th (the 
grandmother of Mr J. J. Moubray's Goldie 32nd) by Groomsman $(70,575)$, grandam by William of Orange $(50,694)$. She had at foot in 1919 a fine red heifer calf by Bridgebank Orangeman. With the old cow there also came the three-year-old red Goldilocks by Dunglass Rocket and her red yearling daughter by Dunglass Clipper (125,301). The Goldies are fine breeders and deep milkers. Mr Murray is illustrating the principle that what is worth doing is worth doing well.

BALTHAYOCK.

Balthayock, a picturesque combination of irregular plateau, scoops between wooded hills, double slopes in part very steep, and whinny moorland, is well aloft from the Tay, facing Kinfauns and the western section of the Carse of Gowrie. The property extends to fully 1700 acres, of which about 900 acres are arable. There are pockets of rich soil on the home farm, but at the edges of these and along the rising grounds whinstone rock crops out considerably, and the higher parts of some fields are apt to become scorched in a dry season. Farther north towards the outlying farm of Oliverburn, about a mile and a half from the mansion-house, the arable land is simply reclaimed moor, and the elevation at that homestead is 600 feet above sea-level. With the exception of one holding of 150 acres the estate is farmed and grazed by the proprietor, Mr Robert Wylie Hill, who has carried out numerous improvements in buildings, fences, drainage, tree-planting and cropping. On the natur- 
ally poor land at Oliverburn the stock now carried is double the number grazed and wintered before Mr Hill bought the farm about fifteen years ago. The grazing improvement is very largely due to the use of deeprooting grasses and wild white clover. An accomplished practical botanist, the proprietor set himself at an early stage to the study of the Elliot mixture, and from that he has taken excellent hints for his own conditions.

A choice herd of Aberdeen-Angus cattle was carried on at Balthayock for a good many years, but the blackskins were sold off in 1911. In 1908 a few Shorthorns were acquired. These were the yearling bull Ivo of Cluny, a thick-set roan of the Dainty family by the Collynie Lord Rector $(83,957)$ out of Daisy 2 nd by Royal Pride $(71,489)$; Lady Waterloo G. from Mr Murray, Kilcoy, and by Kilblean Stamp $(88,978)$; Lady Ramsden, a beautiful roan yearling, second-prize winner at Perth, bred by the Messrs Kerr, Lochlane, and by the Millhills Proud Favourite $(84,420)$; and Strowan Baroness from Major Graham Stirling and by Congalton Conqueror $(88,256)$. Of the females just noted, Lady Ramsden was by far the most valuable. Highly important additions were made to the herd in 1910. At Mr Howard Higson's Meer Hill sale, near Stratford-on-Avon, Mr Hill bought four front-rank Augustas with the much-prized Waverley cross in their pedigree. These were the white Augusta Anguston 2nd; her roan heifer calf Double Augusta 2nd by Golden Arrow $(83,583)$; her very handsome daughter Double Augusta, full sister 


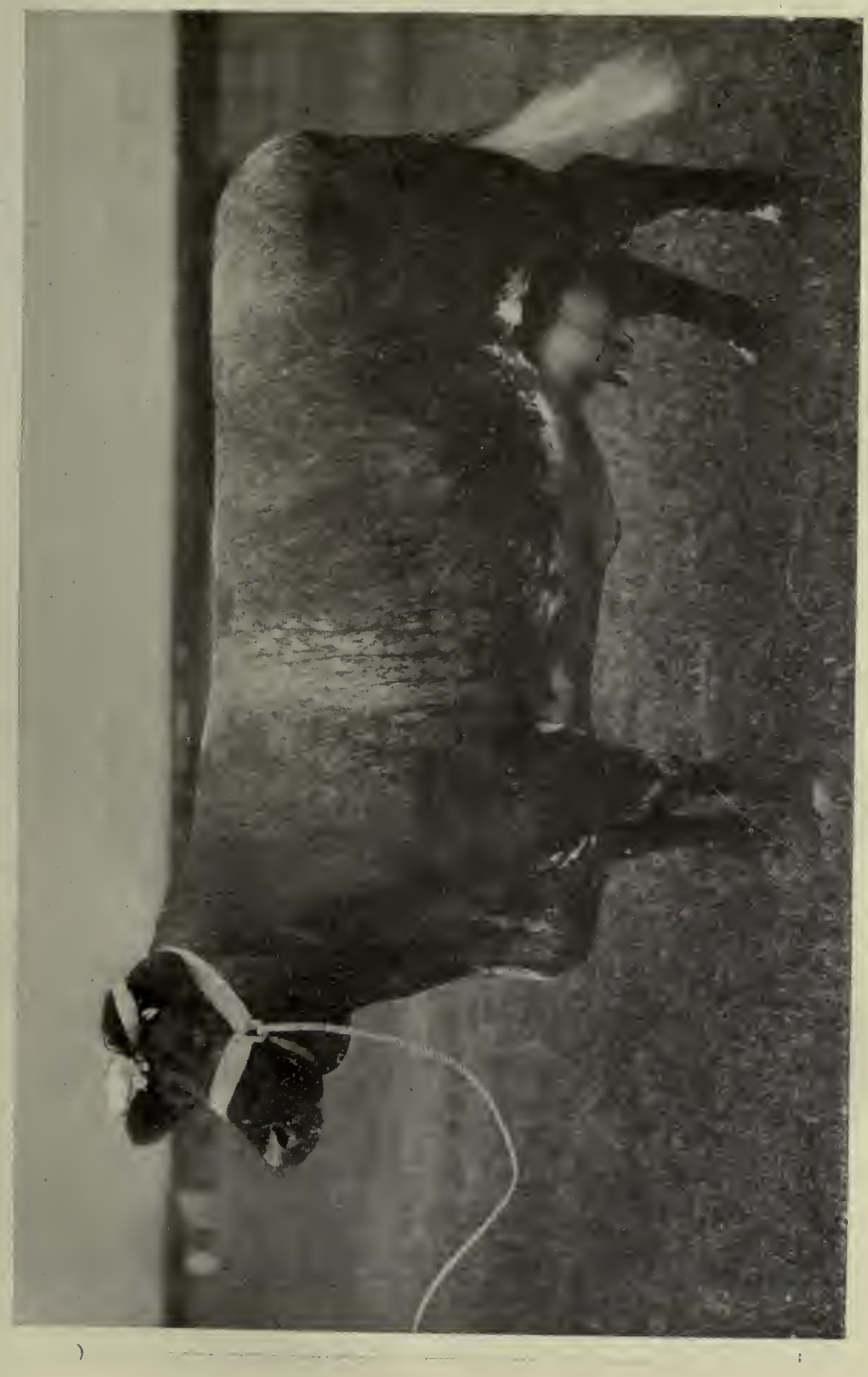

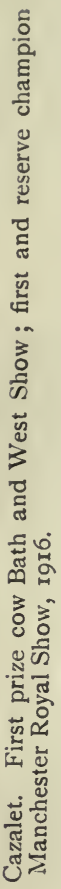

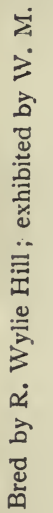



to the calf, and the young cow Fair Augusta. By the time they reached Balthayock the four had cost $£ 1000$, which was accounted a very large outlay at the time. At the Aberdeen October sale of the same season a very fine Orange Blossom heifer calf was acquired from Mr George Anderson, West Fingask. That was Sweet Orange, a red with slight touch of white, sired by Strowan $(107,206)$. The red heifer Augusta Beauty, of the same line of breeding as Augusta Anguston 2nd, was bought from Mr Stephen Mitchell in 1911.

A year later three beautiful Lavenders were secured at Lord Calthorpe's sale, these being Elvetham Lavender Iris, Elvetham Lavender Thyme, and the young calf Elvetham Lavender Iris 3rd, whose dam went to Dalmeny. Elvetham Marigold was another purchase, but she was afterwards sold to Mr Cazalet. Golden Lady, a handsome red Brawith Bud heifer, was a private selection from Windsor the same season. Other purchases included Edgcote Rosemary and Glory Gold, a Brawith Bud from Edgcote, and Victoria 71st from Messrs Lumsden \& $M$ 'Kenzie. A Miss Ramsden heifer from Mr Hunter of Arngask, and a Princess Royal and a Butterfly at the Uppermill dispersion, were the most important of the female additions in 1915. Next season a Broadhooks from Mr Gordon Oswald, and a Rosemary and an Augusta from the Whittingehame sale lot, added to the strength of Balthayock. Of succeeding purchases the more important were Clipper Maid, the very pretty first prize two-year-old at Perth in 1918 ; Auchnacree Moth, a Butterfly; a very fine Secret from Cullisse; 
and a beautiful Violet heifer calf from Saltoun. The Clipper, which was bred by Mr G. C. Greig in Aberdeenshire, cost 300 gs. A high-class eleven-monthsold Nonpareil heifer from Mr M'Allister cost 320 gs. at the February sale of 1919. The more notable of recent additions to the herd have been the beautiful red calf Golden Duchess of Gloster, which cost 1100 gs. at Mr Duthie's sale in 1919, the North Loirston two-year-old heifer, Princess Royal Beauty 3rd, 660 gs., and the very handsome Dalmeny-bred white bull Lothian Buzzard, the first-prize winner in the Perth January class, 1920. His price was 1300 gs.

Coming to bulls and general results, the most notable animal left by Ivo of Cluny was Balthayock Augusta 2nd, a daughter of Fair Augusta. This Augusta 2nd was sold to His Majesty, and in the Royal herd she bred Windsor Augustus, the reserve champion at the Manchester Royal in 1916, and Windsor Knight, the champion at Birmingham in 1919. The Missie bull Proud Beau 3rd (106,627), bred by Lord Merthyr, and by Proud Champion $(100,096)$, was parted with before his real value was discovered. He was the sire of Golden Guinea, the Brawith Bud yearling, which led Mr Donald Maclennan's prices for bulls of the age at the Argentine sales in 1914-also sire of the Orange Blossom cow Tangerine, one of the best females in the Balthayock herd. Of two red half-brothers of the Flowery family bought in 1912, Edgcote Watson $(111,692)$ by Ascott Clipper (86,589), and Pride of Edgcote $(109,675)$, the former was the truer breeder. He left 
some very good heifers. The home-bred Christmas Augustus (114,702), a son of Double Augusta 2nd, was sire of a number of superior animals. His best bull was Cerasus, the second-prize winner in the July to December class at the 1917 Show. This fine bull of the Cherry family was sold for Australia at 420 gs. The most consistent breeder ever used in the herd has been the red Collynie Golden Star $(130,289)$, by Max of Cluny out of Gainford Raglan by Pearl King 2nd $(89,531)$. Golden Star leaves rich colours, beautiful heads, and remarkably smooth moulding along the top. Two of his most admired sons have been Balthayock Ramsden, the third-prize winner in the Perth March class of 1918, and then sold to Major Graham Stirling for $550 \mathrm{gs}$; and Balthayock Golden Sphere, the fifthplaced bull in the same class in 1919, and taken out of the ring at 1600 gs. by Mr Joseph Shepherd, the former being out of Lady Ramsden and the latter out of Sweet Orange. Old Lady Ramsden never left a second-rate calf. Her grandest-looking daughter was Lady Ramsden 3rd, sold to Mr Cazelet as a two-yearold, and afterwards first as a cow at the Bath and West, and first and reserve champion at the Manchester Royal.

The herd usually numbers about 90 head. Nearly two-thirds of the lot are at the home farm, the remainder being at Oliverburn. There are nearly a score of Augusta females, the Miss Ramsdens, Victorias, Lavenders, Orange Blossoms, and Waterloos being next in strength. Privately, and at the NorthEastern autumn sales, demand for heifers and heifer 
calves has been excellent, especially during the last three or four years. At the Aberdeen October sale of 1919 three Augusta heifer calves by Collynie Golden Star averaged $600 \mathrm{gs}$. At the home farm the roomy main byre with its creosoted pine roofing and oneeighth-inch spacings between the boards-set from ridging to eaves--has attracted the attention of advanced stock men. The air in the building is always pure, there is no trouble from rain, and only on rare occasions does a little dry snow come through. Mr Wylie Hill has an admirable blend of business and recreation at Balthayock, and his principal servants can rank with the best.

\section{Bearcrofts.}

The farm of Bearcrofts near Grangemouth may be said to be on the eastern edge of the range of Carse land which stretches across Stirlingshire from the Gargunnock district, east-south-east to the widening of the Forth. Bearcrofts, extending to 180 acres, the property of the Marquis of Zetland, and Awells, running to 90 acres, owned by $\mathrm{Mr} \mathrm{H}$. Graham, Falkirk, are farmed as one by Mr Robert Meikle. The area is typical wheat, beans, and timothy-hay land, merging in parts to a sandy loam. Near the Forth-side beds of sea-shells show that the swish of the salt water must at one time have been powerful where one's footing is now well removed from the furthest encroachments of the tides. It is an exposed farm in the spring of the year, only one or two fields 
having the shelter of a high hedge. Mr Meikle rents 50 acres of grazing land on Abbot's Grange, part of the Blair Drummond property.

On the principle that it is well to let agricultural juniors have responsibilities along lines which appeal to their talents and instincts, Mr Meikle has encouraged his elder son, Mr Robert W. Meikle, to form a select little herd of Shorthorns. The junior made his first purchase in 1911. That was the Jenny Lind cow Countess 10th from the late Mr Thomas A. Anderson, Ballachraggan. Attending the Newton sale in 1916, he secured the beautiful heifer Newton Augusta by Champion of Scotland $(111,261)$. At the Montrave dispersion in 1917 he acquired the grand breeding ten-year-old Clipper cow Eva by Polmaise Handsome Prince $(96,423)$, and in 1919 he made a fine choice at the Newton dispersion in the Brawith Bud cow Golden Jewel by Earl Manvers' Diamond Duke (111,530). From Mr A. J. Marshall's Penrith group of heifers last year Mr Meikle next selected at 320 gs. the red Gay Butterfly of the Blythesome family by Gainford Ringleader $(136,657)$.

The Countess cow is now represented in the herd by Countess Bearcrofts, sire Alfred-the-Great $(107,617)$, and Caroline Bearcrofts by Highland Laddie $(112,068)$. Those are handsome framed cows. Newton Augusta has a fine yearling daughter in Augusta Brilliant by the Doune Lodge stock bull Dunglass Brilliant (120,003), while the old Montrave cow has a lovely red daughter of 1919 birth in Clipperette by the Doune Lodge sire. 
At the Perth Show in 1918 the very promising Bearcrofts Golden Crown, a roan by Golden Glory $(131,230)$, out of Caroline Bearcrofts, took fifth place in the March class, while in 1919 the red Royal Clipper by Butterfly Royal $(130,032)$ from Montrave Eva stood fourth in the December class, and led his group's prices at 820 gs., passing then to Mr Marshall. At the same show Mr Meikle won in two-year-old heifers with the dark roan Countess Bearcrofts 3rd, which Mr Marshall took at 230 gs. The bull in use at Bearcrofts during 1918-19 has been the exceptionally well-bred red Clipper Record, bred by Mr Charles Napier, and by Boquhan Proud Monarch $(124,416)$. His next crosses are those of Watchman by Watchword, Prince of Fashion, and Star of Morning. $\mathrm{He}$ has left some showy red calves.

Buildings at Bearcrofts were never intended for a pure-bred herd, but the young owner of this fine lot of cattle has so far made the very best of the conditions.

\section{BOQUHAN.}

"I want the best," said the late Mr Stephen Mitchell of Boquhan to a trusted expert whom he charged with the duty of selecting foundation materials for a first-class Shorthorn herd. From that standard Mr Mitchell never swerved. For several years he bought a number of Mr Wm. Duthie's best heifer calves, and his representative was entrusted to acquire the finest cows and heifers offered from the leading herds in the country. When the Boquhan herd was 
only a few years on its way the collection of female animals was a magnificent one as seen spread over the rich low ground pastures, along the gentle slopes, and aloft on what the Carse man would term the "dryfield" Dasher Farm. Boquhan itself, on the western edge of the Carse of Stirling in the Kippen country, is mainly on strong clay which tends to become hard in summer and miry in winter. Dasher, with its sharp friable soil, provides the better autumn and winter outrun for stock. From its brae-faces one has wonderful views of Campsies and Ochils and of the rich agricultural valley far spread north and south of the Forth.

In 1906, two years after the herd was founded, $\mathrm{Mr}$ Mitchell had 46 female animals at Boquhan and a score of heifers and heifer calves at Dasher. The females then at Boquhan included 6 Bellonas, 7 Augustas, 3 Broadhooks, 4 Miss Ramsdens, 2 Venuses, 2 Sittyton Violets, 2 Champion of England Butterflys, 2 Clippers, 2 Lavenders, 2 Dairymaids, and single representatives of such noted lines of breeding as the Claret, Clara, Rosewood, Lady Dorothy, Nonpareil, Queen of Rothes, and Kilblean Beauty. At breezy Dasher there were seven Collynie-bred yearling heifers-the white Roan Lady, Lady Rosaline 2nd, by Bapton Champion $(78,285)$; the white Vine, Silver Vine, by Godiva Stone $(88,710)$; the roan Hawthorn Blossom, Hawthorn Berry, by Bapton Champion; the roan Princess Royal, Royal Princess, by Collynie Mint $(88,221)$, out of Collynie Princess 7 th by Royal Edward (82,153); the roan Lavender, Sittyton 
Lavender 15th, by Prince of Sanquhar $(71,251)$; the red Angus or Crofton Rosebud, Scottish Pauline, by Scottish Regent $(93,373)$; and the red Golden Drop, Pure Gold, by Royal Edward. Heifer calves by the Boquhan stock bull included a Dairymaid, a Clipper of the Newton line, a Mayflower, a Lady Dorothy, and a Claret by Proud Monarch (92,961), Bellona twins, and an Augusta by the Cromleybank Prince of Lancaster $(92,907)$, and a Nonpareil by Royal Beaufort $(89,803)$.

The stock bulls then in use were the old Beaufortbred roan Mercury $(77,253)$, of the Mysie family and by Royal Star $(71,502)$, the Cromleybank roan Prince of Lancaster by Royal Crown $(84,598)$, and the red Collynie-bred Proud Monarch of the Dairymaid family and by Proud Edward from a dam by Scottish Monarch $(75,598)$; behind which came William of Orange $(50,694)$, Pride of the Isles $(35,072)$, Royal Duke of Gloucester $(29,864)$, and Champion of England (17,526). Mercury and Prince of Lancaster were good-looking bulls, but they did not have much influence on the herd. Proud Monarch was the highestpriced calf of his year at Collynie. His head was not quite the best, and his horns in old age had a somewhat ungainly set downward by his cheeks. He had also an unreliable temper as he got into years, but he was a remarkable success as a breeder, especially of female animals. His strong concentration of Champion of England blood through a great line of sires, and the high-class character of his dam, grandam, and greatgrandam, account for his excellence as a stock bull. 
Mr Mitchell paid the top price at Mr Duthie's sale again in 1906 for Gold Mint $(95,352)$, a grand-looking roan by Collynie Mint $(88,221)$, out of Collynie Golden Drop 4th by Bapton Champion $(78,285)$. Gold Mint was used for several seasons, but at times he was inclined to transmit his own somewhat "washy" shade of roan. He had a noble-looking head and great scale on short legs. His hook bones were slightly prominent, and he might have been longer behind them, but his "general goodness"not forgetting a fine temper-was undeniable.

By 1910 Mr Mitchell had about 70 head of female animals at Boquhan and Dasher. Most of the cows and heifers which he had bought during the earlier stages-such as a Claret from Mr J. D. Ledingham, a Bellona from Messrs J. \& A. Milne, an Augusta from $\mathrm{Mr}$ A. M. Still, a Clara and an Augusta from $\mathrm{Mr}$ George Campbell, a Butterfly from Mr Jas. Milne, Kincardineshire, a Rosebud and a Broadhooks from Mr C. H. Joliffe, a Kilblean Beauty from Mr John Murray, a Lavender from $\mathrm{Mr}$ Sydney Hill, a Lady Dorothy from $\mathrm{Mr}$ Francis Carr, Kincardineshire, a Clipper from the then Capt. A. T. Gordon, and a Butterfly from Mr David Anderson-were to the fore and looking well. Then there were a good many cows and heifers of Mr Duthie's breeding. In that collection there was no handsomer female than the fiveyear-old roan Queen of Rothes cow Royal Violet by Royal Pride $(71,489)$, from a dam by Merry Archer $(67,477)$. At the same time 15 young cows, heifers, and heifer calves by Proud Monarch made a grand 
appearance. There were also several beautiful females by Gold Mint. Those two bulls were still in regular use, and their heifers were being mated for the most with the red Princess Royal yearling Collynie Cupbearer $(105,069)$, by Jubilant $(99,240)$, dam by Silver Crest $(77,865)$, grandam by Scottish Archer $(59,893)$. Cupbearer was acquired very much on account of his colour. Like his sire, he developed into a rather highstanding bull, but he followed Proud Monarch and Gold Mint fairly well and left rich reds and roans. Colour apart, he was certainly much indebted to his mother Collynie Princess 4th.

In recent years Mr Mitchell's successes had been mainly due to the use of Collynie King Royal (114,768) and Kingston of Edgcote (131,776), but some good animals had been left by Boquhan Mintmaster $(119,116)$ and Boquhan Royalist $(129,758)$. Boquhan heifers always commanded leading prices at public sales. To his wide range of families Mr Mitchell had added during the last few years representatives of the Orange Blossom, Secret, Crocus, and Brawith Bud families. His Augustas are now specially well known, but his Queens of Rothes are unexcelled at Boquhan in the meantime.

The Boquhan byres and courts for wintering heifers are roomy, airy, and convenient for feeding. Ranges of boxes for bulls and animals under extra training are set with outruns to the sun. At beautiful Boquhan Mr Mitchell frequently debated with himself as to whether Shorthorns or Clydesdales had first place in his regard, but his invariable 
summing up in recent years had been: "Carry on: each must be first!" He died on 11th July of this year. (See Appendix.)

\section{BUTCHERCOTE.}

"After a fortnight's shooting holiday in this Border country, I come away with vivid impressions of wiry medium-sized men, long-framed Leicester sheep, and great demons of hares."-Forfarshire Farmer's letter, 1894.

Although Mr Allan M. Douglas is not a Border man except through links of ancestry, he has fallen into the wonderful spirit of the Tweedside, Teviot, Yarrow, and Gala Water country. He has studied the Kaims or Sandhills, the Hopes or Glens, the Laws, the Rigs, the agricultural expanses, the pastoral slopes and uplands, all the way down to the Cheviots. A land of poetry and romance, enterprising farming and stock - breeding, thorough - going fox-hunting, and good-fellowship! Farming in historic Mertoun parish, and looking south, Mr Douglas has Faldonside not far away to the left. Farther off west by St Mary's Loch he has Dryhope. Right over the line of vision the Cheviot Range, the Dunion, Ruberslaw, the Minto Hills, and the Maiden's Paps appear, or show in parts through the mist. The Wisp is to the south-west, and turning farther round the Eildons and Grahamslaw emerge.

Mr Douglas began farming at Spotsmains in 1901, and at the Orchardmains dispersion sale the following season he bought four heifers. About the same time he acquired two or three very good but short-pedi- 
greed heifers descended from stock bred by the late Mr Robert Oliver of Lochside, and his son, now Lieut.Col. James Oliver, owner of the Hoselaw Estate up to 1900. The first bulls used by Mr Douglas were Duke of Cornwall $(80,908)$, bred by Mr Richard Davidson, Swinnie, and Peerless Prince, a white, bred at Legars, and out of the Collynie cow Alexandra 3rd. On leaving Spotsmains for Butchercote in 1911, Mr Douglas practically cleared out his short-pedigreed. Shorthorns. He retained Costly Pearl, a purchase at the Legars dispersal.

In the Messrs Bain's possession this family had the valuable Collynie top-crosses of Earl Marshal (70,343), Bright Boy $(60,403)$, and Day Star $(55,557)$. It traces back to the old Dryhope herd and then to Northumberland blood, and represents the Gems of Dryhope and Faldonside. Mr Douglas bought his first Broadhooks female at Colonel Munro's sale in 1905. That was Airy Duchess 2nd, by the Messrs Bain's Handsome Boy $(76,832)$. A little later he acquired a very fine Myrtle by Diamond Mine (83,296), from Mr James Durno, then of Westerton. In 1906 he added a Lauretta from Lessendrum, and the following season he secured a Brawith Bud from Dr Vaughan Harley. Since 1911 the principal additions to the herd have been a Heatherwick Mayflower, an Uppermill Marigold, a Garbity Mabel-representing the Shethin Mysie family-and a Kinellar Rosebud of Mr R. W. Bell's breeding.

At the present time the herd contains three female representatives of the Brawith Bud family; three 
members of the Broadhooks line, one of them being a beautiful roan by Violet Royal $(90,424)$; three Costly Pearls, two Laurettas, the Mayflower of Heatherwick breeding, a daughter of the Uppermill Marigold, three Myrtles, two Kinellar Rosebuds, one of them being a superb white heifer by Monkshood $(138,049)$.

Some of the best bulls used by Mr Douglas may be referred to. Prince Nonpareil $(92,898)$ of the Maude family, bred by the late Mr John Marr, Uppermill, was acquired at the October sale 1905. He was followed in 1907 by the Garbity Golden Prince $(95,334)$, a dark roan Goldie by Pride of Avon $(86,878)$. In October of that year the white Violet Royal $(90,424)$, bred by $\mathrm{Mr}$ Duthie, came from Uppermill. After being used three seasons, this grandly bred bull was passed on to Colonel Munro. More recent bulls have been Broad Arrow (114,481), a dark roan Broadhooks bred by Mr William Craigie; Bessbrook (124,300), a Bessie from Bruceland; Monkshood (138,049), a home-bred Myrtle red roan by Bessbrook out of a Violet Royal cow ; and Gainford Mandate, a roan Clara bred by Mr George Harrison, and by Collynie Mandarin (119,552). $\mathrm{He}$ is now using the short-legged white Diamond Crest, bred by $\mathrm{Mr}$ Wm. A. Dron, and of the old Keir Mysie family, sire King of Diamonds $(137,377)$, dam by Macebearer $(126,693)$, grandam by Captain of the Mint $(94,565)$.

During his earlier years as a Shorthorn breeder Mr Douglas sold his stock bulls for the Argentine, mostly 
after one season's use. He is now inclined for extended trial. Thus far he has kept about 15 breeding cows. The farm is a somewhat high-lying and exposed one of 320 acres, fully 100 acres of which are rough pastures rising to a rocky ridge and falling abruptly towards Whitrig Hill, on which Mr John Grieve keeps a few Shorthorns, bred by Mr Douglas and representing the Myrtle, Apperly Princess, and Pearl families. Most of the soil on Butchercote is of a stiffish nature over clay and red till from the Sandstone formation.

\section{Cambus and Glenochil. \\ "Broad reaches of chill water overflowing Shiver and take no rest, Under a slow wind that goes blowing, blowing Out of the ashen West."}

So wrote a brilliant Scot (J. W. MacKail) after a fresh impression of a view in the Thames valley above London on a March day when floods were in possession; and he might have passed into a related mood if the Fates had led him aloft from the Forth-side levels of Cambus in a drab hour of winter or early spring. The wind, to his thinking, would fain be gentle under grey skies, but somehow the other elements are unneighbourly. Our seasons, however, have their rich compensations. Brightness and kindliness are never far away. Elusive the best of our meteorologic blessings may be, but we expect the clear shining after rain. There is a suggestion 
of the elderly world about Mains of Cambus, once held in strenuously improving tenancy by Mr John Moubray from the Abercromby family.

The buildings are of another age. Doors, lintels, and roofing at the steading are dourly holding out against Time. An oaken "kist" in the stable must be hundreds of years old. A critic steeped in modernity fancies that far-off leisure and homely substantiality are somewhere in the soul of things. Yet on this spot one man at least lived strenuous days and obtained victories over the forces of nature. It was here, nearly one hundred years ago, that $\mathbf{M r}$ John Moubray began those elaborate experiments in drainage to which reference has already been made (p. 56). Mains of Cambus has an extent of over 350 acres. Fully two-thirds of it is representative Carse clay, the remainder being sharp friable "dryfield" land at an elevation of 200 to 250 feet above the river-side flats. It is at Newbiggin, a well-sheltered plateau above the Carse, and within short reach of the Ochils, that the modern farm residence is set. From that stance one can have a magnificent outlook to the Carse section of the Forth and the great countryside, which is guarded by the Ochils, Campsies, and Southern Grampians. Mr Ebenezer Moubray Alexander, who succeeded his father as tenant last year, also holds Glenochil, a 150 -acres farm, the property of $\mathrm{Mr}$ Alexander Macnab of Middleton, Kerse. That farm, which is about a mile and a half to the north of Newbiggin, may be said to be as close to the Ochils as it 
can get. It has probably the finest range of byres in the county, and general accommodation at the steading is excellent. Most of the land is stronger than the dryfield section of Cambus.

The late Mr John Alexander, who had been tenant of Mains of Cambus for thirty-eight years, began to found a Shorthorn herd there nearly twelve years ago. His first purchases were made at the dispersion of the well-bred cattle owned by the representatives of the late Mr Francis Simmers, Whiteside, Aberdeenshire. The selections then made were a couple of Beautys and one Bright. These throve quite well at the Forth side, but their descendants were gradually sold off. An Averne heifer by the Jackstown Victor Royal $(97,538)$, out of a very good cow by Lord Lynedoch $(74,900)$, was purchased next at the Ballechin dispersion in 1909. Beauty 3rd, a Butterfly by the noted red bull Candahar, so successfully used by the late Sir Hugh Smiley, was acquired later at Mr J. T. Nickell's sale, Day House, Shrewsbury. She became dam of the fine bull Butterfly Victor $(111,206)$, which was exported to Buenos Aires in 1913, and sold there for $£ 1837$. More recently, a Princess Royal and a Lavender were bought from Mr J. Ernest Kerr of Harviestoun. Other purchases were made from Doune Lodge, Saphock, Newton, Dunglass, West Fingask, Old Manse, and Ballechin.

The herd now contains 6 Princess Royals, 4 Avernes, 3 Lavenders, 4 Fancys, 3 Claras, 2 Butterflys, 2 Orange Blossoms, and single representatives of the 
Augusta, Nonpareil, Brawith Bud, Goldie, and Broadhooks families. The principal stock bull is Cluny Regent $(135,789)$, a short-legged blood-red by Hindley Crown $(126,037)$, sire of the Perth Spring Show champion of 1919 , for which Mr William Duthie paid 4000 gs. Cluny Regent's dam was a Dainty cow by Dunglass Commodore $(105,356)$, sire of Mr Duthie's noted stock bull Max of Cluny $(112,487)$. Mr Alexander has one of the best white bulls to be seen anywhere in the Nonpareil Naemoor Comet by Edgcote Masterpiece. This beautiful yearling was not in his best form when shown at Perth, where he stood fifth, and sold for 1050 gs.

Mr Moubray Alexander, the present owner and real builder-up of the herd, has been actively engaged in the export business for a good many years. His intention is to increase the herd on the female side. $\mathrm{He}$ has now a first-class basis. His Avernes are about the best in his possession, but the Princess Royals and Lavenders have done remarkably well. A few Shorthorns may be wintered at Mains of Cambus in coming years, but Glenochil Farm, to which the cattle were recently transferred, is to be the real home of the breeding and export stock. Ranges of bull-boxes will probably be erected there in the near future, and there are possibilities of extensions in cropping and grazing space. Newbiggin is about five minutes' walk from Mains of Cambus steading and Cambus railway station, and Glenochil is near Menstrie station. Alloa is a little to the south-east of both farms. 
Carse of Gowrie.

After the death of George, Lord Kinnaird, the Carse of Gowrie was for a good many years without a herd of the fashionable breed. The late Mr David Anderson, Loan of Errol, then broke the monotony and bred some good cattle for a considerable period. $\mathrm{Mr} \mathrm{Wm}$. Niven, his successor at the Loan Farm and tenant of the adjoining holdings of Murie Edge, Falla, and Inchcoonan, is now vigorously engaged in the Shorthorn export business. He has ample bounds, useful accommodation, and other facilities, and if some of his land is too strong for a breeding herd, it is well adapted for growing plenty of winter keep. He laid the foundations of his herd just before the outbreak of the war with a white Broadhooks heifer calf by Adbolton King Millicent (107,584), from Colonel Munro; a red Emmeline heifer by Broadhooks Earl $(101,655)$, from Tulliallan; a dark roan Wild Duchess heifer by Sunstar $(117,944)$, and a red Emmeline yearling by Redgauntlet $(117,238)$, from Arngask ; a red Lady Waterloo calf by Norman of Cluny $(116,778)$, from Polmaise; and a grandly bred Flora heifer of the Fanfare line by the Collynie Primrose Star $(106,555)$, from Mr Wm. M. Scott. To these he has added members of the Jilt, Augusta, Butterfly, and other fashionable families. At the Aberdeen October sale of 1919 he paid 400 gs. for the roan two-yearold Saltoun Augusta by Newton Count $(132,490)$, and 160 gs. for the red Cadboll-bred Butterfly 41st by 
Garbity New Year's Gift $(136,670)$, which was first at Perth in 1917.

At West Inchmichael, Errol, Mr Ian K. Morrison, one of the juniors in the Carse, began to form a herd in 1913. His first purchase was a red yearling, Scottish Lady, from Mr W. A. Dron, and by Scottish Crest $(113,259)$. She bred a couple of good bull calves and was then sold. Victoria, a roan of the Mysie family and by Broadhooks Victor 2nd (101,658), was also selected from Mr Dron's herd; Lady Anna 2nd, a Wimple by Ivo of Cluny $(99,211)$, came from the Balcarres herd. Two years ago, Waterloo Rose by Birdsall Centaur was acquired from $\mathrm{Mr}$ Wm. C. Hunter of Arngask. This member of an old Bates family was bred by Mr A. M. Gregory. In 1918 a. very fine yearling Goldie heifer was secured from the Doune Lodge lot at $420 \mathrm{gss}$, and much may be expected from her as she is exceptionally well bred. Her sire was the Perth reserve champion Doune Grand Knight $(130,657)$, and she has the crosses of Proud Warrior (106,653), Diamond Earl $(98,591)$, and Scotch Thistle (73,584). A more recent purchase was a red Marigold yearling by Collynie Cruickshank (105,068). Her grandmother was great-grandmother of the Dalmeny first prize, Lothian Marksman, which was sold for export at $3100 \mathrm{gs}$. At the Aberdeen October sale of 1919, Mr Morrison secured from the Milton of Ardlethen group at $400 \mathrm{gs}$. the roan Sittyton Violet 15th by Collynie President $(130,290)$; and from the Nether Dallachy lot, at the same price, the roan Clipper Bride by Bride's Monarch $(141,193)$. Those 
were beautiful calves of the very finest lines of breeding. The Doune Goldie has bred a grand red roan bull calf by Eclipse of Collynie, and Victoria has produced a pretty white bull by Harviestown Baron $(136,965)$, a thick, naturally fleshed member of the Butterfly family by Prime Favourite $(106,546)$. This fine bull unfortunately damaged his head and neck in a barbed-wire fence. At this year's Perth sales the West Inchmichael junior secured a grand young bull in Mr Bertram Shields' May-born dark roan Roysterer of the Secret family, and by Wallace of Naemoor $(139,980)$. Mr Morrison has made a highly promising start.

Waterybutts, a Carse property acquired and beautified many years ago by the late Mr Patrick Hunter, and now owned by Mr Wm. S. Mackie, is quite hid in its orchards. Here Mr Mackie has sought recreation from business by setting Shorthorns as variants against fruit. He began to collect his cattle in 1915. From Mr Wilson of Davidson, Newtyle, he bought Ramsden Blush, a red with little white, by Findon Veteran $(98,621)$ from a dam by Red Granite (106,726), and Lady Fanny 3rd, a red Mary o' Argyll by $\operatorname{Sir}$ Randolph $(113,368)$. The following year, he took a finely bred roan Myrtle cow from Rothiebrisbane, sire Golden Sittyton $(105,643)$, dam by Pride of the Herd (100,007). Then he added a very pretty dark roan Golden Drop yearling from Boquhan, sired by Collynie King Royal (114,768), a two-year-old red Butterfly by Bystander (119,298) from Abbey Mains, a red Shethin Lovely yearling by Nigel of Cluny 
$(116,747)$ from Auchnacree, and a Strowan Baroness yearling by Balthayock Lavender $(114,991)$ from $\mathrm{Mr}$ Wylie Hill. In 1918, Lady Grace by Dunglass Royalist $(108,496)$, and her yearling daughter by Edgcote Czar $(120,081)$, were bought from the representatives of the late Mr John Watson, Strathaven. At the Aberdeen sale he further strengthened his herd by adding a very finely bred dark roan Goldie heifer calf from the Whittingehame Mains herd, sire Collynie Silver Knight $(124,851)$. This calf is closely related to Mr J. J. Moubray's noted red cow Goldie 32nd. Mr Mackie's bulls have been the red Butterfly Auchnacree Vizier $(129,241)$ of Mr G. R. Grant's breeding and by Nigel of Cluny (116,747); King of Scots, a dark roan bred at Tulliallan, sire Merry Victor $(116,563)$ from Carnation 6 th by Lancaster Royal $(109,108)$; and the present stock bull, also from Tulliallan, the light roan Royal Gem, a very handsome son of Lancaster Royal out of a Kilblean Beauty cow. Mr Mackie has some pretty calves, and altogether his outlook is hopeful.

\section{Claymoddie and Cruggleton.}

Nearly twenty years ago Mr Matthew Marshall, Bridgebank, Stranraer, bought two or three Shorthorns for his elder son, Mr Albert James Marshall. Since that time the young man has gone far in the Shorthorn world. He now owns the largest herd of the breed in Scotland, if not in the United Kingdom, and he has a strong position in the export trade. A 
clever manager and business man, the junior has profited greatly from the shrewd advice and selective genius of his father. When the herd was making its way Bridgebank almost sufficed for its grazing and wintering, but about nine years ago it became absolutely necessary to take another holding. Claymoddie, fully thirty miles east-south-east, in the Whithorn district, was leased, and for a few years the cattle, with the exception of bulls in preparation for shipment, were kept on the farm beyond Luce Bay. Over two years ago still more space was urgently required, and the very desirable farm of Cruggleton, east-northeast from Claymoddie, near Garlieston, and on the western edge of wild Wigtown Bay, was also leased. Last year Mr Matthew Marshall bought Cruggleton and the two neighbouring farms of Palmallet and Cults from Sir Andrew Agnew, Bart., of Lochnaw. All over, the Messrs Marshall now hold about 2000 acres of land, and practically all the Shorthorns, usually numbering from 350 to over 400 head, are kept on the peninsula between Luce Bay and Wigtown Bay.

The herd is famous for its Augustas. It has about 100 females of that family, 40 Princess Royals, the like of Claras, 17 Rosebuds, 15 each of Secrets and Rosewoods, and 10 Clippers. Other families represented are the Orange Blossoms, Nonpareils, Broadhooks, Brawith Buds, Miss Ramsdens, Jilts, Lancasters, and Marr Bessies, Goldies, and Blythsomes. One line of Augustas, acquired from the late $\mathrm{Mr} \mathrm{Wm}$. R. Trotter, has the cross of Mr Deane Willis's Stephen Fitz Lavender $(73,732)$, which was out of the same 
dam as Golden Garland, the Royal English female champion of 1906; another line, from the late $\mathrm{Mr}$ Henry Williams, has the late Mr Thos. C. Booth's Sir Archibald Christon $(75,639)$ over Waverley $(68,072)$; while a third has Mr C. H. Jolliffe's Primrose Knight $(84,357)$ and Choir Boy $(91,238)$ as immediate followers of the favourite Inverquhomery sire. Still further, there is a direct line from Mr James Bruce's Augusta 95 th by Waverley and with the W. S. Marr Highland and Dublin winner Royal Eclipse $(87,179)$ to follow. The Princess Royals and Claras in $\mathrm{Mr}$ Marshall's herd had their start from Uppermill and Dairsie Mains purchases. The Rosebuds are from the Ballechin Red Rosebud by Marquis, the highest-priced bull of his time in the Argentine. Secrets were acquired from the late Mr John Gordon, Cullisse, Mr James Coey, Larne, and Mr Richard Cornelius, Shropshire. Rosewoods have sprung from three sources, including Mr Thos. O'Malley's Rosebud by the Princess Royal bull Scottish Favourite $(84,722)$ and the same breeder's Rosebloom by Mendel $(103,025)$, a son of Scottish Favourite. The Dallachy, Mains of Sanquhar, and Montrave branches of the Clipper family are represented in the herd, the first named being from Mr Napier's leading heifer at Perth a few years ago. Then the herd has two branches of the Orange Blossom family. It would be practically impossible, within the limits of ordinary space, to follow out Mr Marshall's numerous purchases. One thing may be noted : he has never been afraid of expense. In buying heifers and bulls he has been one of the gamest and 
most enterprising of men-quite a terror to the ordinary bidder. The result is a very remarkable herd in general excellence, and one with top-crosses second to none at home or abroad.

Until two years ago Mr Marshall sold all his spare heifers to home breeders or exported them. At the Penrith October sale of 1918 , however, he offered 39 yearling heifers for public disposal, and he had an average of over £333. Mr J. J. Moubray then took a beautiful red Princess Royal by Broadhooks Diamond $(124,530)$ at 800 gs., while Mr Cazalet secured a pretty roan Lavender by White Knight $(128,848)$ at 875 gs., the latter being from a dam by Lothian Augustus $(116,354)$, the sire of Broadhooks Diamond. Last year Mr Marshall sold a grand lot of 36 yearling heifers at the same centre and struck an average of $£ 461$. Lord Lovat paid 1350 gs. for the magnificent dark roan Princess Royal, Princess Yolando, by White Knight. This high-class heifer had the crosses of Choir Boy (91,238), Sea King (61,769), William of Orange $(50,694)$, and Cherub 4th $(33,359)$. For a very fine dark roan Secret by Broadhooks Diamond, and with the great bulls Prince of Fashion $(64,587)$, Sovereign (61,841), Vice-Chancellor (56,681), and Gondolier $(52,956)$ in her pedigree, the Earl of Moray's agent paid 1000 gs. For a much-admired roan Princess Royal by the Gainford Ringleader $(136,657) \mathrm{Mr}$ George Harrison paid 900 gs. This heifer and Lord Lovat's purchase were fourth in descent from the Uppermill Princess Royal 94th by Royal Diamond $(84,600)$, a son of Bapton Diamond $(78,289)$. A grand- 
daughter of this Uppermill cow by White Knight, dam Princess Alice by Choir Boy, passed to Mr C. H. Jolliffe at 870 gs., and a granddaughter of Princess Alice, sired by Broadhooks Diamond, was taken out of the ring by the Messrs Peterkin, Dunglass, at 800 gs. The noted heifer-getter, Broadhooks Diamond, was sold to $\mathrm{Mr}$ Wm. M'Allister, Drakies, Inverness, last season.

Some of Mr Marshall's most successful bulls may be referred to. The Broadhooks Viceroy 2nd $(82,526)$, bred by Lord Lovat and sired by Royal Star $(71,502)$, proved an excellent stock bull. His sister was dam of the Beaufort Broadhooks Champion, which was sold at Perth in 1906 for the then record price of 1500 gs. Viceroy 2nd was first and champion at Inverness and Belfast, and junior champion at Dublin in 1902. The following year he was first at Dublin and reserve to Mr John Handley's Pearl King for the championship at Belfast, and second at Park Royal. In the Argentine he changed hands at $£ 1600$. One of the most impressive of sires followed in Mr Jolliffe's Primrose Knight (84,357), by the grand Collynie bull Primrose Pride $(79,605)$, sire of Pride of Avon, Pride of Tees, and other famous animals. Primrose Knight's grandmother was full sister to the great Beaufort-bred champion New Year's Gift. Roan Conqueror $(84,519)$ won most of his reputation as a show bull. Bred by the Messrs Peterkin, his sire was Collynie Conqueror $(78,609)$, the Dublin champion, and his dam was Ruby by Chieftain 2nd $(70,152)$. In 1903 Roan Conqueror stood second to Mr Deane Willis's Bapton Sceptre, 
which was afterwards the leading yearling at the Royal. As a two-year-old Mr Marshall's bull was champion at Edinburgh, first at the Perth Highland, and reserve to the Windsor Ronald for the championship. The following season Roan Conqueror was champion at Dublin and the Glasgow Highland, and at Park Royal he stood reserve at the final to Royal Emblem (82,154). He was then exported to the Argentine, and sold for 1750 gs.

Mr Marshall's showyard successes attracted attention to the Bridgebank herd. When one good show bull was exported another was selected. Fascination $(85,954)$ by Lord Lynedoch, and full brother to the late Colonel A. T. Gordon's Fascinator $(88,569)$; the Collynie Matchmaker $(86,590)$ by Nonpareil Courtier $(79,488)$, out of the Missie cow Mistletoe 20th by Scottish Archer $(59,893)$; and Mr Jolliffe's Choir Boy $(91,238)$ by Chorister $(76,351)$, out of the great cow Rose Lynedoch by Lord Lynedoch, the sire of Royal Emblem, followed Roan Conqueror. Choir Boy proved a striking success as a breeder. His females gave the herd a great forward impulse. The reputation of the herd was more than maintained by the Saphock Diamond Star $(98,593)$ by the noted Diamond Star $(91,478)$ out of the Broadhooks cow Ellen Terry 4th, the Uppermill-bred roan Lady Royal Eclipse $(87,179)$ by Bapton Favourite $(76,080)$, and Dunmore Sirdar $(95,029)$, a brilliant prize-winner until he met with an accident in 1908. He was by the famous Linksfield Champion $(86,401)$, the most perfect show bull of his time. 
The most noted bulls used in Mr Marshall's herd during the last few years have been the roan Lady White Knight $(128,848)$ by Knight of Collynie $(112,229)$; the magnificently-bred Gainford Ringleader $(136,657)$ by Collynie Mandarin $(119,552)$, out of the Rosebud cow Gainford Welfare by Pride of Tees $(96,474)$; Edgcote Crystal $(136,363)$ by Edgcote Guardsman $(115,269)$; Edgcote Earl $(136,367)$ by the great Earl of Kingston (120,041) from Irish Welcome by Candahar (78,522); and Edgcote Hero (136,371), the Dublin, Belfast, and Edinburgh Highland champion of 1919, sire Earl of Kingston, and out of the Eliza cow Evelwyn by King Christian of Denmark (86,316). The Royal English champion Gartly Lancer, the noted Dublin champion Pellipar Iris, and Fairlawne Forester, the winning Royal junior yearling, can only be referred to as remarkable show bulls. Mr Marshall's showyard record of last season with bulls has probably never been equalled.

A strong south-west wind plays at times over some of Mr Marshall's land. It has a considerable sweep across the upper fields at Cruggleton, especially; but the grazing season is long. There is manifest advantage in the open-air life for the ordinary run of the female stock and the bulls which are growing easily towards the exportable stages-eighteen to thirty months. Flies are sometimes troublesome during the long days, but the perfect place has still to be discovered. 


\section{ClotchFoldich.}

On the beautiful south-facing slopes overlooking one of the most charming bits of Strathtay near Grandtully, Messrs John and Donald Robertson have been breeding some Shorthorns for about ten years. Since 1914 the Cloichfoldich herd, now of fair size, has come into note mainly through the general excellence of its heifers. The Messrs Robertson began with female animals of the Carnation, Lady Dorothy, and Rachel families, from the herd of the late Mr Alexander Robertson, Ballechin. To these they, in course of a few years, added a Village Maid from Colonel Munro; a Butterfly from Captain Macgillivray, Aldie ; a Queen of Rothes and a Flowery from Mr Douglas, Rhynie ; a Princess Royal from Messrs Munro, Moness ; and a Jealousy and a Broadhooks from Mr Moubray of Naemoor. The Jealousy cost 450 gs. as a calf at the Aberdeen autumn sale of 1919. A full sister to Mr Moubray's Perth champion bull of 1916, she is a singularly handsome dark roan. The Cloichfoldich tenants have been prominent in the Perth prize lists with heifers, principally of the Lady Dorothy and Queen of Rothes families. Among the bulls used have been the home-bred First Favourite $(111,774)$, a Lady Dorothy by the Ballechin stock bull Golden Favourite $(98,960)$, of $\mathrm{Mr}$ Duthie's breeding; the Naemoor Question Mark $(109,803)$, and Rufus $(117,567)$, of the Rosebud and Bessie families respectively; and the noted Keir sire. 
All the best heifers shown by the Messrs Robertson for several years have been by the dark roan Keir Quartermaster $(120,896)$, bred by BrigadierGeneral Stirling and calved in March 1913. That bull is by Edgar 2nd of Cluny $(91,611)$, out of the Queen of Rothes cow Beaufort Queen 2nd by Master Millicent $(84,080)$. Master Millicent was the sire of the famous breeder Millicent Chief $(96,096)$, which is referred to in connection with the Polmaise and Dalmeny herds.

Congalton.

After the death of Mr Joseph Lee, owner of Congalton, Mr Joseph G. Scott, then finishing a lease at Kinpurnie, Newtyle, took up the tenancy of the noted East Lothian farm. Mr Scott's first selection of a Shorthorn was at the sale held by Mr Lee's representatives in 1913. He then took out Congalton Helen, by Lord Leith $(95,842)$, and she produced Helen's Favourite, one of the best young cows in Mr Scott's herd. In 1914 Butterfly Lass 12th, a red, by Minmore Quilter $(109,417)$, was bought from Mr D. H. Moore, the well-known Ross-shire breeder. Her roan bull calf of 1918, by Lothian Rambler, was sold at Perth in 1918 for 230 gs. As true a breeder as any of the earlier purchases has been Boquhan Dorothy, a red bred by Mr Stephen Mitchell, and with Proud Champion $(109,765)$ as sire. A heifer calf out of her, by the Tulliallan Royal Beau, was sold to the King for 210 gs. Rosemary Princess, bred at Rothiebrisbane, 
and by Golden Sittyton $(105,643)$, was one of the good purchases made in 1915. Two of her daughters, Congalton Rosemary 9th by Royal Beau, and Congalton Rosemary 10th by Doune Augustus, are of great promise. Sunnyblink 15th, bred at Corston, and of the Shuttlefeather family so much liked by the late Mr James M'William, was by the noted Strowan Butterfly 24th $(104,110)$. She promises to be a highclass bull breeder.

In $1916 \mathrm{Mr}$ Scott added to his herd two fine heifers bred at Fingask House, and by Merry Matadore $(112,530)$. Those heifers were the Brawith Bud Golden Maid, Nonpareil Lady, and Corston Lustre 10th by Strowan Butterfly 24th. At the Perth spring sale of the following year Esther 12th, a smart-looking Clipper by Julian (120,876), was secured from the Earl of Crawford's lot at 200 gs. Her first calf was a heifer, for which Mr George Walker, Tillygreig, paid 300 gs. at Perth in 1918. Balthayock Orange Blossom 4th, a pretty roan by Edgcote Watson $(111,692)$; Bessie 205th, bred by Mr C. H. Jolliffe, and by Prince of the Blood $(96,532)$; Roan Groat 2nd, bred by $\mathrm{Mr} \mathrm{W}$. Ingram Middleton of Troup, and by Auchnacree Whyte $(118,644)$; Proud Princess, a Tillygreig-bred Miss Ramsden by Collynie Sweepstakes $(124,852)$; Lady Lancaster, a Saltounbred red by Monarch $(138,037)$; Ida Ramsden, a beautiful roan yearling of Mr A. J. Marshall's breeding, and by Broadhooks Diamond (124,530); Balnakyle Augusta 4th by Ossian of Cluny (121,904); Auchnacree Moth 24th, a Butterfly by Ramsden Rufus 
$(138,717)$; Stevenson Myrtle 4th by Throsk Broadhooks 24th $(133,930)$; Broadhooks and Princess Royal, calves from Balnakyle, were the more important purchases from 1917 to 1919. The Claymoddie-bred Miss Ramsden heifer cost 400 gs., and the Balnakyle Princess Royal $900 \mathrm{gs}$.

$\mathrm{Mr}$ Scott, as will be noted from the next paragraph, should very soon be able to select first-class heifers of his own breeding to build up a herd fit to rank among the best. He occupies a fine stock-breeding farm, and if stimulus were needed he has it in the past and present records of a remarkable countryside. The earlier bulls used by Mr Scott have been referred to. Royal Beau was a red Kilblean Beauty by Lancaster Royal $(109,108)$. Doune Augustus, a short-legged red now in the Harviestoun herd, was kept for only one season by Mr Scott. His sire was the Perth reserve champion of 1917, Doune Grand Knight $(130,657)$, and his dam was Doune Augusta by Diamond Earl $(98,591)$. At the Perth sale of 1919 Mr Scott took out of the ring at 700 gs. Lieut. A. Macrae's stylish dark roan Brawith Bud calf, Kinbeachie Crest, by Dunglass Crest $(136,260)$. Mr Scott parted with Kinbeachie Crest at the Perth spring sale of this year, and he then bought at 1150 gs. the red Dolphingstone Broadhooks bull Duplicate by the champion Sanquhar Grand Courtier $(139,193)$.

A remarkable and costly addition was recently made to the herd by the purchase of the famous cattle owned by Mr C. H. Jolliffe of Newbus Grange, and numbering 37 head. It was the most important recent 
transaction of its order. The lot include four Princess Royals, four Rosebuds, and one or more representatives of the Uppermill Missie, Roan Lady, and Maude families; also members of such high-class lines as the Orange Blossom, Eliza, Augusta, Broadhooks, Queen of Rothes, Nonpareil, Lady Dorothy, Blythesome, and Beauty. Along with the female animals two bulls were taken over. These were the great six-year-old Quartermaster $(132,925)$, bred by $\mathrm{Mr}$ J. Duthie Webster and full brother to Mr Wm. Duthie's Masterstroke $(126,820)$; and the yearling Collynie Challenger, a red Lady Dorothy by Crusader $(130,468)$.

The vigorous tenant of Congalton has substantial farm buildings, which were not originally planned for a Shorthorn herd. They have been considerably improved for more recent developments. For the rest he has a beautiful residence and picturesque surroundings.

\section{Conston.}

Most of the poor land in Strathmore lies along the trough of the valley. Parts of it might not have satisfied the Wise Man who summed up his aspirations modestly in "Give me neither poverty nor riches." The western fields on the world-famous farm of Corston, not far from the Sidlaws, are well up towards the slopes, but they are naturally poor. After two or three years in grass they tend to revert to bent (Agrostis) and crested dog's-tail ; with a little more time they would renew their old acquaintance with whins and broom. More than half a century of 
high-class farming by father and son hide such matters from strangers. The remainder of Corston, and the main portion of Baldinnie, farmed along with it, are composed of useful loam, the total extent being about 500 acres. The late $\mathrm{Mr}$ David Buttar bred some blackskins, and his son, Mr Thomas A. Buttar, the present tenant, followed for a few years on the same lines, and also produced remarkable crops of blue greys; but in 1904 he started a Shorthorn herd. His first purchase of consequence was a Goldie from $\mathrm{Mr}$ Buckley. She was by Dream of Millions (72,378), a son of the great bull Wanderer $(60,138)$. At Corston she produced Golden Flower 3rd by Nonpareil Crown $(96,221)$. The $3 \mathrm{rd}$ produced Goldies 4 th and 7 th by Royal Reign $(103,747)$ and Strowan Butterfly 24th $(104,110)$. Then the 4 th of the line bred Golden Flower 5th, which was sold to Sir James Sivewright, K.C.M.G. That cow, mated with Merry Victor, bred at Tulliallan the lovely heifer calf for which $\mathrm{Mr}$ A. W. Maconochie paid 450 gs. at the Aberdeen autumn sale of 1918 .

At Colonel Munro's sale Mr Buttar bought the Shethin Mysie cow Red Rose by the Lovat Sir George $(60,593)$, and the Miss Ramsden Royal Jubilee by the Newmore Lord Dunraven. To Royal Reign the latter bred Minx, the dam and grandam of some beautiful heifer's. In 1905 Mermaid 3rd, another Miss Ramsden by Sigmund $(67,905)$, came from Mrs Law, New Keig, but this line has run mostly to bullbreeding. Peggy 3rd, a fine red Jilt by the Uppermill Court Favourite $(83,196)$, was bought from $\mathrm{Mr}$ 
George Campbell, and to Nonpareil Crown she calved Peggy 4th, a great breeder, which bred the 8th and 10th of the line by the grand white bull Schoolmaster (110,095). Peggy 3rd, it may be noted, bred eight bull calves in succession. Taking a strong liking to the Jilts, Mr Buttar bought another of the line from the late Mr John Young, Tilbouries, who, commenting one autumn on the condition of his calves, summed up, "Girse [grass] a' gane, but they've hed some rinnin' watter an' graun scenery." Mr Young's Jilt was Scottish Rose by the Uppermill King Victor $(81,394)$. She became dam of the Angus champions Corston Rose and Corston Jilt. The former was sold for U.S.A., and the latter bred to Regal King Goldie $(117,294)$, Royal Jester $(127,669)$, the Perth juniorclass winner of 1915. From Mr Young at the same time Mr Buttar took a pretty Bellona heifer calf by the Collynie Sittyton Choice $(84,822)$. She was named Corston Strawberry. Two of her sons won third prizes at Perth, one of these being sold to $\mathrm{Mr}$ Nettlefold, Kent, at 550 gs. The old cow, now over her fourteenth year, is still fresh-looking, and she has a handsome daughter in Bellona 4th, by Strowan Butterfly 24th $(104,110)$.

A very fine group of Rosewoods at Corston descend from Rosewood 91st, a red roan in calf two-year-old bought from Mr George Walker, Tillygreig, in 1906, and by the Duthie Pride's Farewell $(84,350)$. One of her sons was Rosewood Crown, the Perth secondprize bull of 1909 in the March class. A pretty family of Primroses is descended from the Strathtay 
Primrose 10th, by the Collynie Village Bard $(87,630)$. Shuttlefeathers have proved fine breeders. The first of them came from the late Mr Francis Simmers. The family has swayed strongly to bull-breeding. Radiance, one of these, was second at Perth in 1915. A third strain of the Miss Ramsdens, and a splendidly successful one, is from Bella, a great roan cow bred by Mr William Smith, Cairnie, Keith. One of the finest families is the Lustre, from Lustre 14th, bought at the dispersion of the late Mr Simmers' herd in 1908. That cow was by Cash Box $(66,791)$. One of her daughters, Corston Lustre 6th, was sold to the Earl of Rosebery, and was dam of the noted show bull Lothian Lex. The 10th of this line passed into $\mathrm{Mr}$ Joseph G. Scott's herd. Waterloo Princess 33rd, of $\mathrm{Mr}$ Simmers' breeding, and by the Collynie Count St Clair (74,300), has bred pretty heifers. The first Broadhooks came from Dunglass, but she was bred by Mr Gordon-Oswald. Roan Broadhooks 3rd, another of the same family, and by Star of Scotland $(90,232)$, came from Mr William Craigie. Missies and Roan Ladys of Rothiebrisbane and Tilbouries origin have done remarkably well. A fine family of Lavenders came from the old Pirriesmill Lavender Thyme 9th. Orange Blossoms are well represented. They are from the West Fingask Orange Blossom 14th by Strowan $(107,206)$. Then there are Augustas from Mr Wm. Craigie's Augusta Lady by King's Knight $(99,286)$, and Secrets of the first rank from Fairlawne Secret 2nd by Collynie Crown (111,334), and with the crosses of Gravesend, Cumberland, and Roan 
Gauntlet. A great show the cows make on the Corston pastures.

Of the earlier bulls used, the Cromleybank roan, Nonpareil Crown $(96,221)$ by Royal Crown $(84,598)$ was the best. The red roan Lady Royal Reign (103,747), acquired at Mr Duthie's 1909 sale, proved a very true breeder. Sired by Royal Edward (82,153), his dam was by Waverley (68,072). In $1911 \mathrm{Mr}$ Buttar made a highly fortunate purchase in the white Secret bull Schoolmaster $(110,095)$, bred by the late Colonel A. T. Gordon, and by the famous Bandmaster $(97,929)$. Schoolmaster transmitted beautiful heads and wonderfully well-finished quarters. Regal King Goldie promised to breed fine stock, and Mr ParkinMoore's roan Lady Dorothy Donnybrook $(119,895)$ by Keep Smiling $(105,835)$ was undoubtedly exported too soon. The old red Strowan Butterfly 24th $(104,110)$ bred grand females, just as at Auchnacree. Hean Conqueror $(131,417)$, the red Clipper bought in 1915, has proved a reliable breeder, but the roan Collynie Favourite $(135,818)$ would rank among the best anywhere. He leaves bulls and heifers equally good: distinguished-looking Shorthorns in character and conformation, and of rich colours. He is by Max of Cluny $(112,487)$, out of Clipper 4 th by Golden Primrose $(98,979)$.

Crieffrechter.

Some Shorthorns were kept at Crieffvechter prior to 1860 by the late $\mathrm{Mr} \mathrm{Wm}$. Dron, but no particulars 
regarding them have been preserved. It was at $\mathrm{Mr}$ John Gardiner's dispersion sale in 1861 that $\mathrm{Mr}$ Dron took seriously to the idea of founding a herd. $\mathrm{He}$ had won prizes at Crieff with his Shorthorns in 1860 , and he thought of further developments when the Kinkell sale gave him an opportunity. He then acquired two heifers, a Marchioness and a Mysie. There are no representatives of the Marchioness line in the existing Crieffvechter herd, but from Mysie 7 th, the other purchase, by the Sittyton Indispensable $(16,295)$, there is a strong show of high-class females. The Mysies were from a race of short-legged, deepmilking cows, which had not only to rear their own calves, but to keep the dairy side of the homestead well supplied. Mr Dron had a good neighbour in the late Mr Maxtone Graham of Cultoquhey, who generally bought the best of the Sittyton bull calves. This accounts for the names of Cruickshank bulls well down in Crieffvechter pedigrees.

In $1893 \mathrm{Mr}$ Wm. A. Dron, son of the founder, and now owner of the herd, bought a fine roan heifer named Pride 15th from Mr Stott, Powburn, Kincardineshire. That heifer, which was by the Uppermill Match Him $(53,296)$, developed into a handsome cow, an excellent milker and breeder. Pride 22nd, a granddaughter of the Powburn heifer, won the Shorthorn Society's prize for best dairy cow. One or two other families have been tried in the herd in course of the last quarter of a century, but to all intents the Prides and Mysies have had real command of the situation. Mr Dron made an important addition 
at the Newton dispersion in 1916. There he took out at 290 gs. the lightish roan two-year-old Clipper heifer Newton Charity, a daughter of the beautiful red cow Charity 11th, which went to Millhills at 600 gs. Newton Charity was by the grand white bull Newton Crystal $(92,658)$, the sire of Bandmaster $(97,929)$, Count Crystal $(108,276)$, and other famous animals. About eighteen years ago Mr Dron had a stroke of good fortune. At the Uppermill sale of 1899 the late Mr Duncan Stewart bought the Goldie bull Golden Gift $(81,168)$, which was used for two seasons at Millhills. Mr Dron then acquired the bull, and from that stage the Crieffvechter herd went straight ahead.

Used for several years, Golden Gift left a remarkably fine lot of heifers and a number of show bulls. His best son probably was the Perth first-prize winner Golden Arrow, which was sold to the late Mr Donald Maclennan for $260 \mathrm{gs}$., the top price of the time. The bull was afterwards second at the Royal, and in the Argentine he was sold for $£ 875$, which was then regarded as an astonishing figure for a yearling. In $1911 \mathrm{Mr}$ Dron won at Perth with the pretty bull Princely Favourite $(112,873)$ by the Millhills stock bull Proud Favourite $(84,420)$. Princely Favourite was sold to Lord Lovat for 660 gs. The dam of the young bull now referred to was a Dalmeny Regina cow of exceptional breeding merit, as five bull calves from her averaged $253 \mathrm{gs}$.

Some of the bulls used by Mr Dron during the last ten years may be noted. The Duthie bulls Christ- 
mas Carol $(105,031)$, a red of the Queen of Rothes family, and Golden Sunlight $(111,936)$, proved very good breeders. The latter was sire of the Perth 2nd prize bull of 1914, which was sold to Mr Maclennan for 500 gs. Broadhooks Victor 2nd (101,658), bred by the Earl of Northbrook, was a bull of great substance, and he left some excellent females. One of these, Village Blossom, mated with the Millhills Cupbearer of Collynie $(114,860)$, bred the short-legged dark roan Macebearer $(126,693)$, which was sold in the Argentine for $£ 1745$. One of the best breeding cows now in the herd is Lady Betty, by Mr Stewart's Collynie Cruickshank. Her dark roan son Golden Charm by Cupbearer of Collynie was sold to $\mathrm{Mr}$ Maconochie in 1917, and he was sire of the Cudham Court reserve group at Birmingham last spring, including the white Cudham President, for which $\mathrm{Mr}$ Duthie paid 1700 gs. In course of the last three years good results have followed the use of the Duthie Gloaming Star (136,732), an Augusta by the Millhills Clipper Star (124,786), and the Stow-on-theWold King of Diamonds $(137,377)$, which is out of the Saphock Diamond Actress, the first calf to make 500 gs. at Aberdeen. Mr Dron is now using the dark roan Doune Majestic, a very blocky-framed mellow-handling roan, for which he paid 1500 gs. $\mathrm{He}$ is by Dunglass Brilliant (120,003), and is out of the same dam as Doune Grand Knight, the Perth reserve champion of 1917 .

As already indicated, Mr Dron's herd on the female side runs mainly to Mysies and Prides. The Clippers 
are now proving their high qualities. In the favourite old families there is remarkable uniformity of character, and the milking powers have been well preserved. To his old friend and neighbour, the late Mr Duncan Stewart, Mr Dron has been greatly indebted for the use of front-rank bulls. Then he has always acted on the sound principle of keeping the best heifers. As a rule, he has had no difficulty in disposing of his surplus heifers privately. The farm, which was bought by Mr Dron a few years ago, lies pleasantly to the sun. Most of it is a loam of very fair body, and stock thrive well on it.

\section{DALCAPON.}

Once upon a time breeders of Highland cattle held command on the airy Braes of Tullymet, overlooking the magnificent valleys of Tummel and Tay, but at Dalcapon, on the Atholl estate, above Ballinluig, Shorthorns have been bred since the sixties of last century. The late Mr Donald Fergusson, a representative of one of the oldest families in the Vale of Atholl, and a man who was admired and respected by all classes, began to breed a few Shorthorns in the early sixties. He bought the highest-priced bull at Messrs Macdonald, Fraser, \& Co.'s first sale in 1865. That was Colonel Williamson's Harry $(27,391)$, Royal Harry $(27,367)$, which cost 36 gs., a figure then accounted too high for a man who kept non-registered and crossing stock. Mr Fergusson did not take up registration on exporting lines until the eighties. In 
1887 he bought Lily 3rd (vol. 36) from the late $\mathrm{Mr}$ Maxtone Graham of Cultoquhey, and he followed up with Matilda's Lady from Mr Kinross, Coldstream, and Averne 4th and the Crofton Rosebud, Regina, from Mr Smith, Balmain, Laurencekirk. The first bull which Mr Fergusson had from Averne 4th won second at Perth. That was the beginning of a long series of spring show successes for Dalcapon. $\mathrm{Mr}$ Alexander Fergusson, the present owner of the herd and son of the founder, states that the Crofton Rosebuds are the best breeders in his possession.

From 1892 down to 1909 many additions were made to the herd. Strawberry Blossom of the Rosemary family and Lowland Lass were acquired from Mr Taylor, Uras, Stonehaven; Graceful and Lady Agnes of the Dairymaid line of breeding were bought from Dunglass; Clematis (vol. 48) and Wild Duchess of Geneva 130th were secured from Mr D. Macdonald, Comrie Farm, Aberfeldy; a Mysie was added from Miss Lathom, Strathord; and in 1909 a very fortunate purchase was made in Madge 8th from $\mathrm{Mr} \mathrm{A}$. Watson, Bruceland. That heifer was of the noted Matilda family, which has done so well at Windsor. Lowland Lass was dam of the second-prize bull at Perth, 1894, and the Mysie produced the prize bulls Stewart Jamieson and Caledonia. The latter won a number of prizes at English shows for Captain Harrison. The Wild Duchesses are excellent milkers. Clematis 3rd, a daughter of the original purchase, was a prominent county prize-winner, and she took the commended card at the Aberdeen Highland of 1908. 
Madge 8th bred the fine bull Proud Chief, the Cork Show Champion of 1916. The more recent purchases include Hean Mysie from Mr Wylie Hill; Broadhooks 25th from Mr Anderson, Nonakiln; a Lady Dorothy from Mr J. Knox Ledingham; a Butterfly from $\mathrm{Mr}$ George Murison, Balnagubs; a Rosewood from $\mathrm{Mr}$ Robert Copland, Milton of Ardlethen; and an Augusta from $\mathrm{Mr}$ W. P. Turner, Cairnton.

The principal families now in the herd are the Augustas, Rosewoods, Butterflys, Lady Dorothys, Broadhooks, Matildas, Crofton Rosebuds, Rosemarys, and Wild Duchesses. From 15 to 20 cows are kept.

In its early stages, when short-pedigreed cows were kept, the female animals in the herd were quite as good as any to be seen in later years. The bulls then used included Master Henry (31,868), Master Cowslip (31,862), Baldowrie $(65,091)$, Royal Alfred $(66,176)$, Bolshan 2nd $(58,535)$, and Baker $(62,101)$. After the short-pedigreed cows were discarded, the first bull to leave a distinct impression was the Beaufort-bred Groam Duke $(65,623)$ of the Broadhooks family. As a yearling he won the championship at Inverness, and the late Mr Fergusson bought him as an old bull and kept him three seasons. Groam Duke showed excellent Shorthorn character. He was of great scale, very level, and deep in frame. His colour was a peculiarly "ticked" roan, the red markings being in very small spots all over his frame. His stock were always in the prize lists or short leets, and they commanded high average prices.

Inspector $(72,715)$, bred by Mr Crombie, Woodend, 
was perhaps the neatest and showiest bull ever used in the herd, but he was no great success as a breeder. As an old bull in the possession of Mr George Harrison he had a brilliant show-ring career, being practically always a first-prize winner, and several times champion at the leading open events in the three Kingdoms. One of the best breeding bulls ever used at Dalcapon was Star of Atholl $(77,962)$, a short-legged, very blocky-bodied roan bred by Colonel Munro, and out of a Myrtle cow which the Colonel had bought as a calf from Mr James Durno, then of Westerton. Star of Atholl bulls stood second on two occasions for the group prize at Perth. Mr Alexander Fergusson's comment on Bushey of Cluny $(78,507)$ was, "He was certainly the best bull my father ever owned." A singularly handsome roan, with a beautiful head and a perfect back, he had long neatly-finished quarters. He won all round at the County Shows, and took second as a twro-year-old at the Aberdeen Highland. As a breeder he gave the highest satisfaction. His sire was the Collynie Royal Pride $(71,489)$, which Mr Duthie bought back from Lady Cathcart.

Among other bulls used at Dalcapon have been the Messrs Law's Scotch Monarch $(84,718)$; the Beaufort Reformer (89,801), third-prize winner at Birmingham; Dalcapon Victor $(94,820)$, bred by Mr John Barnes; Proud Duke $(117,109)$, bred by Mr W. M. Scott, and second-prize winner at Birmingham in 1913; Redgorton Envoy $(144,809)$ and Brawith Chieftain $(141,177)$, the sires of the young bulls and heifers now coming forward. 
Dalcapon homestead is about 600 feet above sealevel, and some of the land is much higher, and just at the edge of the heather. Grass is somewhat late in appearing, but it holds on well through autumn. In most seasons, however, it is rather difficult to get the bull calves far enough on in condition before they are put into their winter quarters. The herd has been managed with rare judgment by the Messrs Fergusson, and young stock from it have always been in keen demand.

\section{DALMENY.}

The Earl of Rosebery's original herd of Shorthorns was founded in 1891 with purchases of the best female animals procurable from the Beaufort, Collynie, Uppermill, Kinellar, and other Northern herds, the principal selections being Roan Duchess 2nd and Underley Princess from Beaufort ; Lady Lancaster 3rd, Lady Lancaster 7 th, Fragrant Blossom, and Veronica 2nd from Collynie; Missie 131st and Missie 132nd from Uppermill; a Claret, a Ury Lass, a Nonpareil, and a Mina from Kinellar. Leading stock bulls in the earlier stages of the herd's history were Lord Provost $(65,846)$, Dictator $(65,338)$, and the noted prizewinner Sittyton Seal $(64,866)$, all bred by $\mathrm{Mr} \mathrm{Wm}$. Duthie; and Strowan Marquis $(63,417)$, bred by the late Mr Graham Stirling. Most of the cattle were sold on 7 th September 1897 at an average of $£ 29$, 1s. 6 d. for 66 head. The highest price was 120 gs. from the agent to the Prince of Wales, 
afterwards King Edward VII., for the six-year-old cow Fragrant Blossom. Her heifer calf accompanied her at $65 \mathrm{gs}$. Both were for the famous Sandringham herd. The late Mr Duncan Stewart made his first Shorthorn purchase at the sale, his choice being Veronica 2nd, for which he paid 81 gs. Mr W. A. Dron paid the top price of $100 \mathrm{gs}$. in the male section for the handsomely-proportioned roan Minotaur of Dalmeny by Lord Provost out of the Kinellar Mina cow. A small portion of the first herd was kept going until 1901, and then disposed of privately.

Mr J. T. M'Laren, who must be highly complimented on soundness of judgment in founding and building-up the present herd, made his first selection at the Berkeley Castle draft sale on 15th July 1909 in the grand-looking Royal winner Waterloo 70th, which cost 320 gs. This roan cow, with her beautiful head and almost perfect symmetry, was greatly admired at the time, and her female descendants at Dalmeny show charm of character, substance, and milking powers. Heifers of the Beaufort Broadhooks and Julia or Dairymaid families were bought at the Stirling "Highland." One of them, Empress of Millcraig, with Ringleader blood, bred several beautiful females to the noted Millicent Chief. Lothian Baroness of this breeding took first prize at York in 1913, and was secured by Mr Cazalet. None of the earlier selections promised greater things than did Augustine 2nd, a light roan two-year-old from Sir Herbert Leon's Bletchley Park herd, and by the 
Collynie Silver Mint out of Augusta Royal by Cornelius, a full brother to the champion Corner Stone. Unfortunately she had to be slaughtered after a bad second calving. Her first calf was Lothian Alain by the Saphock Diamond Mariner (102,000), and her second was the distinguished-looking dark roan Lothian Augustus $(116,354)$ by Millicent Chief. Lothian Augustus was well placed at Perth spring show, and there he was bought by $\mathrm{Mr} \mathrm{Wm}$. Duthie at 1400 gs., the top price of the sale and the second highest at the Scottish spring sales for many years.

At the October sale in 1909 two heifers, which proved excellent breeders, were acquired. These were a red Mayflower from Heatherwick, and Esther 8th, a Clipper from Muirton of Barra, Old Meldrum. The latter produced three heifers and four bulls at Dalmeny, and was then sold to Mr Hunter of Arngask. To Collynie Grand Duke she bred handsome twin bulls which were in the Perth prize list of 1918. $\mathrm{Mr}$ James Sidey took one for export at $340 \mathrm{gs.}$, and Mr George Harrison took the other-Lothian Clipper Duke-at 200 gs. At Crewe in $1918 \mathrm{Mr}$ Harrison won the championship with Clipper Duke, which was sold to $\mathrm{Mr}$ Wm. Hartnett, U.S.A., for 650 gs., the leading price of the sale. In June 1910 Princess Royal A by Captain Jolliffe's Chanticleer $(91,192)$ was added to the herd. She was a shy breeder, but to Lex of Cluny she produced two very fine roan heifer calves. The herd is rich in Kilblean Beautys. The first member of the favourite old Aberdeenshire family secured 

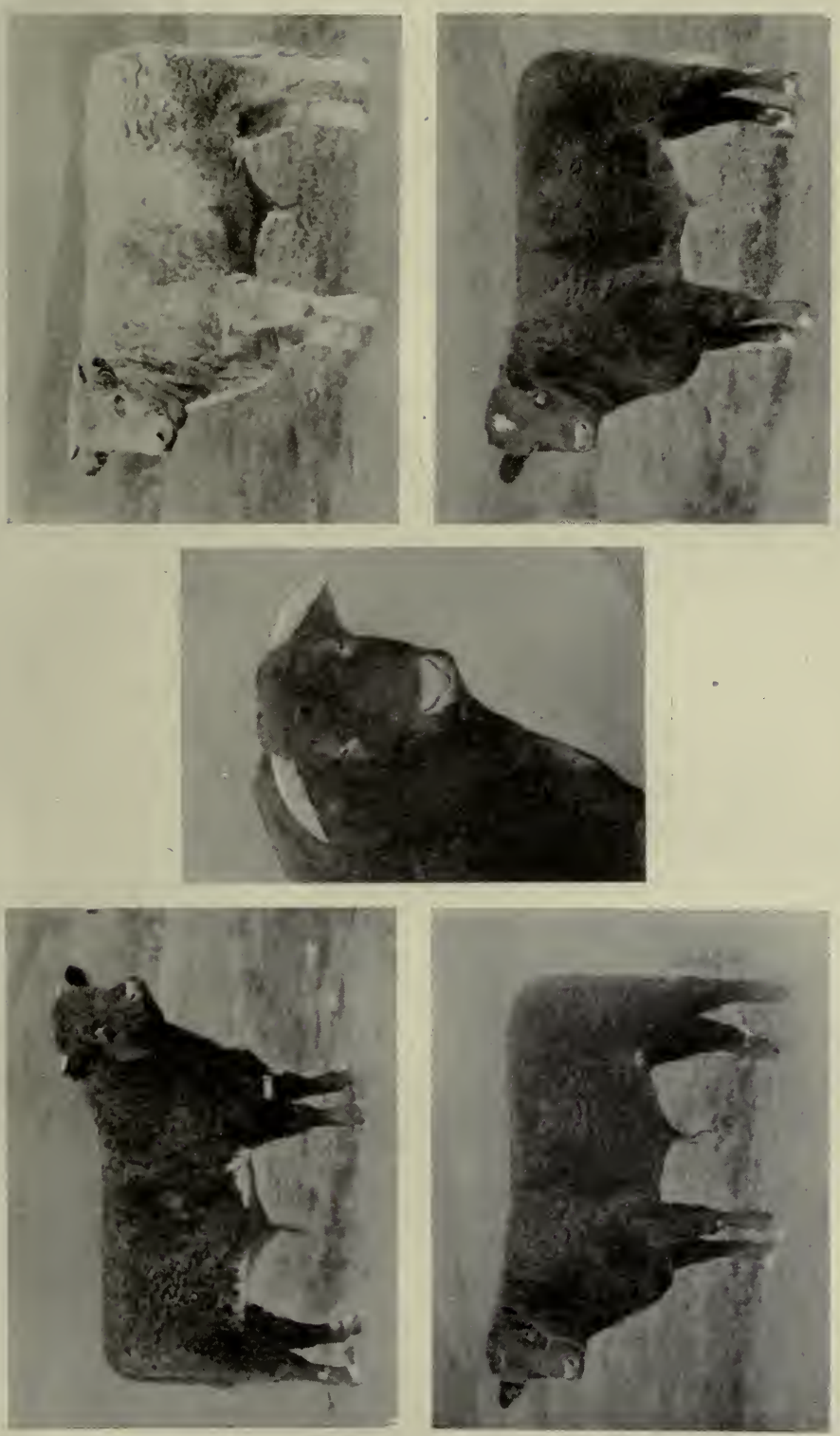

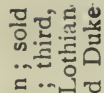

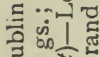

ดิ 8 帘

สี

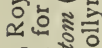

تี

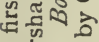

$\because$ 荧

iो का कू

$8 \mapsto \infty$

ल४⿻

웡

콩ㅎㅇㅇํㅇ

के

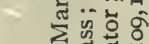
뒁 < त幽

- $ᄋ \stackrel{3}{\frac{3}{3}}$

S 응 突宁

요에

- 9 - 1

$\rightarrow$ बूरें

प

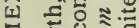

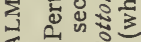

2 की

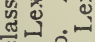

용

초ำ 조

르

랭ํำ

(1)

-

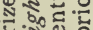

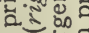

ज东茄

舟

ฮี 은

ํํํำ

ज्ञ

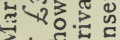

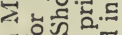
¿ 릉ํㅇำ 뎅도 1 아녕의 는. है 

for Dalmeny was Keir Belle, a roan heifer bought in 1909, and still a regular breeder. It is somewhat singular that this cow and her daughters have so far produced only heifer calves. There is no better family in the herd than the Marigold. From Mr George Veitch in 1910 a most fortunate purchase was made in the roan cow Princess Marigold by Prince Edgar $(100,036)$. At ten years old her breeding record is 5 heifers and 3 bulls. Mated with Collynie Grand Duke, she produced the blood-red 3000-gs. bull Lothian Mario, which did so well in Colonel Johnston's herd at Linksfield, Elgin. Lothian Marquis, her calf in 1917, is proving an impressive sire in the Wester Lovat herd. Put to the home-bred Fairy Gold $(115,355)$, Princess Marigold calved Lothian Martha, a beautiful red heifer, and that heifer when only turned two years old bred to Collynie Grand Duke the dark roan bull Lothian Marksman, which led the Perth February class in 1919, and was sold for 3100 gs. to Mr A. J. Marshall. So far, no heifers of the Marigold family have been offered from the herd.

The noted white Lavender Iris 2nd, now seventeen years old, was taken out at the Elvetham dispersion sale in 1911. Four of her progeny are in the herd, a specially prized one being a dark roan three-year-old heifer by Collynie Grand Duke. The Nonpareil family is well represented at Dalmeny. Gartly Nonpareil Countess, bred as her name indicates on a well-known Aberdeenshire farm and by County General $(111,407)$, came south in 1914, and she has three daughters in the herd. Of the fine Goldie family, so highly 
esteemed in the North-East, the herd has several representatives descended from the red cow Merry Goldie, one of the 1912 purchases. To sum up, the herd now consists of the following families: Augusta, Broadhooks, Brawith Bud, Butterfly, Beauty (Kilblean), Clipper, Goldie, Julia or Dairymaid, Lavender, Lustre, Marigold, Mayflower, Nonpareil, Queen of Rothes, Miss Ramsden, Princess Royal, Wimple, Waterloo, and Violet.

Possession of a really good and impressive stock bull means much for a herd, especially at the earlier stages. The Beaufort-bred red Millicent Chief $(96,096)$ proved himself a valuable sire at Dalmeny just as at Polmaise. He was by Master Millicent $(84,084)$, out of the Dairymaid cow Maydew by Lancer (83,846). Millicent Chief had a beautiful head and a strong well-covered back, and if he lacked something in hind-quarters, his stock were all right there. The white Nonpareil bull Lex of Cluny $(109,170)$, which was used for several seasons and then exported to the States, strengthened the herd very much in the female line. Sired by the neat and fleshy Edgar 2nd of Cluny $(91,611)$, and out of Nonpareil Blossom 3rd by Radnor of Cluny (64,620), Lex was a wonderfully thick-fleshed smooth bull. For close ribbing and turn of hook bones he had very few equals. The principal stock bull at the present time, the red roan Collynie Grand Duke $(124,844)$ by Lothian Augustus $(116,354)$, from Lady Dorothy 55th, a noble cow by Royal Leader (103,727), has made a great reputation. At last year's Perth sale in 
February the Dalmeny bull calves averaged $£ 1428$ for four - the second highest figure ever recorded at those disposals. At this year's sales four averaged $£ 1131,7 \mathrm{~s} .6 \mathrm{~d}$. As a first-class red was required, especially to cross with the Grand Duke heifers, Mr M'Laren selected at Mr F. L. Wallace's sale of last autumn the beautiful Goldie calf Balcairn General by the champion Edgcote Hero (136,371). The young bull cost 2200 gs.

In comparatively recent years, byres and boxes for cows and calves, and partly open-court sections for heifers, have been much improved in the interests of fresh air, comfort, and convenience. The later addition has been a range of bull-boxes second to none for airiness, light, and feeding facilities. At Dalmeny, stock-breeding and cropping have thoroughly well-balanced attention under the direction of $\mathrm{Mr}$ George Sinclair, the manager, who is completely at home in every department. Some of the land suffers during a summer drought, but the scope of the enclosures, the generally fine loamy character of the soil and its high condition, mainly through farmyard manure, favour grazing and winter feeding. It is a centre with many attractions for the man whose ambition is to go far in mixed farming.

\section{DARGILL.}

It was practically inevitable that $\mathrm{Mr}$ James Gardiner, M.P., should pass from specialising in potatoes to general farming and stock-breeding. 
Early-life training and long experience in dealing with rural affairs steadily strengthened the "call of the land." In 1912 he leased the compact farm of Dargill on the Ancaster estate, near Crieff. A sharply friable 240-acres holding, with a gravelly subsoil for the most part, Dargill shrivels up to some extent in a dry season, but it grows good quality of produce and is prettily set in a district which is never without charms. An excellent steading for commercial purposes is being modified and slightly extended for Shorthorns, and the herd is now fairly on its way. It contains members of the Secret, Augusta, Rosewood, the Sunshine branch of the old Mayflower, Charlotte Corday, Myrtle, Marigold, Butterfly, Goldie, Brawith Bud, Lady Dorothy, Shethin Mysie, Princess Royal, and Mary o' Argyll families.

The first purchase was a Mysie by Strowan Butterfly 28 th $(117,922)$, from Mr Waterson, Stewart Tower, Stanley, in 1913 ; but no selections of special consequence were made until 1918, when the founding of a herd was set about with thoroughness and under the stimulus of Millhills. In the spring of $1918 \mathrm{Mr}$ Gardiner secured a couple of Broadhooks yearling heifers from Mr Gordon-Oswald of Aigas in White Lady by Prince of Orange $(132,831)$, and Dainty Jewel, a red by Royal Mascot $(133,324)$. At the Cullisse sale in autumn he added another of the same family in Lady Zona, a red two-year-old by Red Emperor (87,026), from a dam by Merry Archer $(67,477)$. Cullisse Vinolia, a roan Brawith Bud cow by the Crieffvechter Choirmaster $(114,699)$, was another 
selection from the late Mr Gordon's herd. Marigold Nymph 2nd, a massive red roan, bred by Mr Scott Wyllie, and out of a dam by Cupbearer of Collynie, was a Crieff and Perth winner in 1919. She cost 210 gs. In $1919 \mathrm{Mr}$ Gardiner returned to Milton of Luncarty, and bought the light roan heifer calf out of the Cupbearer cow.

The Lady Dorothy was a Mounteagle sale purchase in the autumn of 1918. Good females were added at the Aberdeen autumn sale of that year in Doune Charlotte Corday, a roan yearling by Doune Grand Knight $(130,657)$, and the Shethin Mysie three-year-old roan Scottish Mysie, which was out of Kitty Gray, one of Colonel Munro's show cows. Attending Birmingham sale in November 1918, Mr Gardiner bought a Rosewood calf from Colonel H. T. Fenwick; a Secret calf at 300 gs. from Sir Herbert Leon, Bart. ; a Champion of England Butterfly of Auchnacree breeding from Mr William C. Hunter; an Augusta cow from $\mathrm{Mr}$ A. A. Gatty; and a Princess Royal yearling by Collynie Matadore $(111,337)$ from Mr J. D. Fletcher. A very fine white Goldie calf by Merry Victor $(116,563)$, from a Lancaster Royal $(109,108)$ cow, was acquired from Tulliallan at the Aberdeen October sale of 1919. It will thus be seen that the busy tenant of Dargill has set out on his Shorthorn course with firstclass foundation stock.

Command of a high-class stock bull is always a strong asset, and very specially in the case of a man who is bringing diverse elements under subjection. $\mathrm{Mr}$ Gardiner has one of the best bulls in the country 
in the red Aldie Emblem $(140,384)$, bred by Captain Macgillivray, and by Proud Emblem $(100,099)$, so successfully used at Saphock, out of a grand breeding cow of Mary o' Argyll descent by the Garbity Royal Pride (106,935), a son of Pride of Avon. Aldie Emblem has been champion at the Strathearn Show and first at the county event. With ordinary good fortune Dargill should go far.

\section{DarlingField.}

On the extensive farm of Darlingfield near Kelso, Mr Hugh B. Stirling has been forming a Shorthorn herd as balancing effect against Clydesdale horses and the breeding and feeding of sheep. The farm has about 600 acres in rotation and 150 acres in permanent grass, and the soil ranges from light and porous in parts of the higher fields to loam of fairly useful strength and depth on the lower enclosures. In $1918 \mathrm{Mr}$ Stirling bought from Mr Greig of Eccles a couple of finely bred young cows. These were the roan Ballechin Carnation, Strathtay Beauty, by Strathtay Major (123,152), out of a dam by Tom Bowling $(97,441)$, grandam by Marquis $(84,061)$, which was sold for $£ 2000$ in the Argentine; and Gay Lass, a white Newton Pauline bred at Millhills, and by Cupbearer of Collynie (114,960), out of a cow by Captain of the Mint $(94,565)$, sire of the famous Cluny Castle President of the Mint. From Mrs Burnyeat's draft at Penrith he next selected a Broadhooks, a roan heifer by Lavender Royal King 
$(116,185)$, out of a dam by Morning Star $(109,463)$; a two-year-old roan of Phantassie Flower descent by Collynie Gold Cup (124,842), whose dam was Collynie Julia by Lord Matadore $(106,046)$; and a pretty roan heifer calf by Knight Champion (131,804), out of Moresby Beauty by Collynie Gold Cup. A red Myrtle yearling was added from Mr Grieve, Whitrig Hill. This heifer is by Mr Douglas's Bessbrook (124,300), and from Myrtle 2nd by Broad Arrow. $\mathrm{Mr}$ Stirling has two or three beautiful calves. A roan by Rouge Royal out of the Pauline cow is a gem. At the Aberdeen spring sale of last year he acquired the very short-legged thick-set Kilblean Beauty bull, Mayor of Brussels, a roan bred by $\mathrm{Mr}$ George A. Bruce, and by Vulcan of Naemoor $(134,187)$, dam by Pearlfinder $(116,911)$.

\section{Dolphingstone.}

At the large and fertile East Lothian farm of Dolphingstone, on the Preston Grange property, near Tranent, Mr George Bertram Shields, the vigorous and enterprising tenant, has varied interests. With Clydesdale horses of the best lines of breeding, a famous flock of Suffolk sheep, growing of early and late potatoes, specialising in seed wheat, and breeding of Shorthorn cattle, the man in possession of this front-rank 640-acres farm has scope for exercise of judgment, and ample opportunities for putting finishing touches on organisation. Enough of shelter from east and north is provided by the old policy timber, 
and no field is spoiled for cropping purposes. $\mathrm{Mr}$ Shields laid the foundation of his Shorthorn herd in 1915. At the dispersion sale of the late Mr John Marr's herd he bought the dark roan two-year-old Lavender Lady 7 th, by the great stock bull Royal Leader (103,737). She was then in calf to the neat red Pirriesmill-bred Esmond (111,713), for which $\mathrm{Mr}$ Cazalet paid 320 gs. The Aberdeen joint-sale of the same week provided another selective opportunity. There Mr Shields made a highly fortunate purchase in the Earl of Moray's yearling heifer Doune Broadhooks, a finely-proportioned roan by Lex of Cluny $(109,170)$, out of a grand breeding cow by Diamond Earl $(98,591)$. The Doune Lodge heifer was in calf to Collynie Gondomar $(124,843)$, and the result was a very pretty red heifer. She bred another heifer calf in 1917, and thus made her family line secure. But when one is seemingly on the way to the crest of success it is well to beware of a knock back. Another Broadhooks, a Clipper, and a Sittyton Violet were secured in the North, but they came down croppers the following season, the only per contra to the good being a bull calf from the Clipper. Misfortunes did not quite end with the disappearance of three fashionablybred and high-priced heifers, but only one mishap need be recorded in these introductory notes. The roan Princess Secret, bred by Mr George Veitch, and bought at the Marquis of Crewe's sale with her red heifer calf by Sanquhar Searchlight, looked like a splendid investment. No better bred Secret could be found than that cow, as she had Prince Edgar $(100,036)$ for 
sire and the backing of Royal Crown $(84,598)$, Stanmore $(66,380)$, Cumberland $(46,144)$, Roan Gauntlet $(35,284)$, and Pride of the Isles $(35,072)$. To the Dalmeny stock bull, Collynie Grand Duke, Princess Secret bred the beautiful dark roan Rubicon, the reserve champion at Perth in 1918. That bull was sold to His Majesty the King for 1450 gs., and he led the two-year-old class at the Edinburgh Highland of 1919. Shortly after the birth of Rubicon his dam slipped and broke a leg. She had to be destroyed, but her daughter strengthened the line of succession in due course by means of a very fine red heifer calf. At the Balnagubs sale, in Kincardineshire, a red Butterfly cow, with Rosario and Rosario $\mathrm{K}$ between her and Champion of England, was taken out of the ring, and she has done well in East Lothian. A young cow of the same family, and by Jack Tar $(115,987)$, was afterwards bought from Mr C. W. Kellock

The years 1916-17 were important in Mr Shields' herd-building scheme, as he added representatives of the Clipper, Princess Royal, Kinellar Rosebud, Claret, Sittyton Violet, Nonpareil, Crocus, Miss Ramsden, Rosewood, Orange Blossom, and Lady Dorothy families. In every instance he sought a combination of high-class merit and the finest pedigrees, with the natural result that initial outlays were heavy. As satisfaction, however, he had a magnificent collection of cattle. Two of his finest-looking selections were a red Crocus and a roan Princess Royal, both yearlings from Mr J. Deane Willis's herd, 
the former a great heifer by Bapton Reuben $(114,127)$ from an Alnwick Favourite mother, the latter by Mr Parkin-Moore's Hoarfrost (112,077), out of a cow by Royal Crest $(106,894)$, grandam by the champion Village Diamond (100,981). A very fine Clipper heifer of the Cinderella branch, and by Dunglass Brilliant (120,003), was taken from Doune Lodge, and a red roan Princess Royal, somewhat closely related to the Bapton Manor one, was bought from Mrs Dixon of Gunthorpe. The Rosebud, a handsome red heifer by the Collynie Proud Champion $(100,096)$, and from a daughter of Ballechin Rosebud 6th, was a Whittingehame purchase, while the Claret came from Mr D. D. Williamson's herd at Auldtoun of Carnousie.

A lovely roan. calf was acquired in Violet Maid, bred by $\mathrm{Mr}$ Alfred $\mathrm{H}$. Reid of Hillhead, and by Lothian Laird $(112,374)$. The Miss Ramsden, a roan by Strowan Butterfly 24th $(104,110)$ out of dam by Schoolmaster $(110,095)$, came from Corston. Many considered her the best calf of her year in Mr Buttar's herd. Of the Rosewood, one may say that she was a prettily-built red calf in Mr Charles Napier's group of 1917. Sired by Boquhan Proud Monarch (124,416), she had the favourite Waverley and Cap-à-Pie crosses. There could not be a more choicely-bred Orange Blossom than Mr Shields' white calf, bred by Mr James Durno, Uppermill, and with four Collynie top-crosses. The Queen of Rothes was a beautiful roan calf from the Wester Lovat group. Her sire was the Saphock Proud Nonpareil $(122,232)$, and her grandmother was 


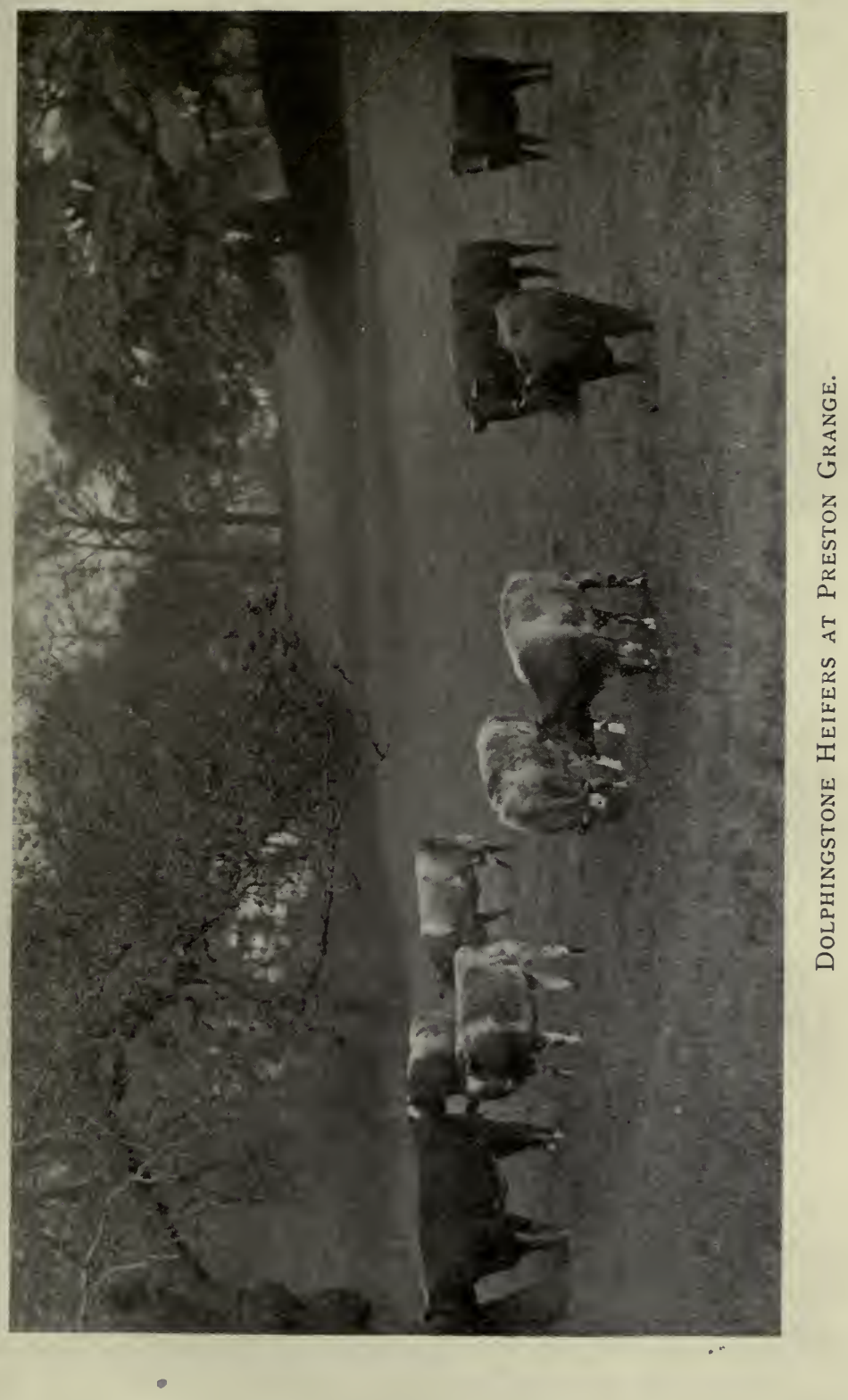



by Cornelius (66,804), a full brother to the champion Corner Stone. A red Lady Dorothy heifer by Collynie Grand Knight $(119,549)$ from Mains of Sanquhar, and a splendidly-bred red Nonpareil from Rosehaugh and by Collynie Matadore (111,337), rounded Mr Shields' leading purchases up to the end of 1917. In 1918 he added a very finely bred red yearling, Brawith Bud, from Mr A. J. Marshall's Penrith lot, the sire of that heifer being Broadhooks Diamond $(124,530)$, her dam being by Royal Luxury $(106,919)$.

At the outset Mr Shields had access to the Dalmeny stock bulls. One result has been noted in the prizewinning Rubicon. A daughter of the Lex of Cluny cow, Doune Broadhooks 2nd, mated with Sanquhar Grand Courtier $(139,193)$, then owned by the Earl of Moray, afterwards the property of Captain Fletcher, bred the Perth first-prize bull of 1919, D.S.O., for which Capt. Macgillivray paid 3300 gs.

In the meantime Mr Shields has about a score of cows and 36 females in all, but ere long his breeding standard may range from 25 to 30 cows. Last year he had five Princess Royals, and three each of the Secret, Orange Blossom, Clipper, and Broadhooks families; two each of the Crocus, Violet, Claret, Lavender, Butterfly, Nonpareil, Queen of Rothes, and Rosebud lines of breeding; and singles of the Lady Dorothy, Miss Ramsden, Rosewood, and Brawith Bud families. The most important of recent purchases in the female line is the magnificent roan heifer calf Naemoor Zoe 2nd, for which he paid 1400 gs. at the Aberdeen autumn sale. This remarkable calf is by Edgcote Masterpiece 
$(115,277)$, out of Sanquhar Zoe 27 th by Collynie Grand Knight (119,549). The stock bulls are high class. At the Birmingham autumn sale of $1918 \mathrm{Mr}$ Shields took out of the ring, at 1500 gs., the champion bull Shenley Colonel, a very handsome red Augusta by a son of Mr F. L. Wallace's famous Earl of Kingston (120,041). In 1918 also he acquired privately, at a very high price, the dark roan Fairlawne Clipper King, a double Clipper, the pick of Mr Cazalet's calves, sire Collynie Clipper King $(135,816)$, dam by Violet's Victory, grandam by Corner Stone $(68,406)$. He made an important selection further from the Hon. Frederick Wrench in Baron Groat 2nd, a beautiful red by the noted Red Baron $(112,982)$.

At Dolphingstone the female animals are left in the more sheltered fields until about Christmas, and all the young cattle are out for a portion of the day during winter. Two-year-old heifers not in calf are never under a roof. Young bulls in preparation for the spring shows and sales have "out-and-in" boxes, so that they may have plenty of fresh air. Mr Shields has remodelled the steading to a large extent in order to fit it for the housing of a valuable herd under modern conditions.

\section{Doune Lodge.}

It was in 1905 that Francis James, sixteenth Earl of Moray, decided to found a Shorthorn herd on his beautiful Perthshire property. "Select a few animals to begin with, and let them be good," was the general 
instruction which his lordship gave to his local agent, Mr John Scrimgeour. How skilfully and faithfully $\mathrm{Mr}$ Scrimgeour acted all Scottish breeders know. Five cows were bought in 1905 and two heifers in 1906 from the Moness, Pirriesmill, Stoneytown, and Ballechin herds, one of the cows being the Meg Merrilies, Lady Maud of Rettie descent, which cost 180 gs. - the top price of that season-at Stoneytown. At the Perth sales of 1906 the handsome red firstprize Westerton-bred Diamond Earl $(98,591)$ was acquired at $700 \mathrm{gs}$. At the dispersion of the late Mr Francis Simmers' herd at Whiteside in 1908 the excellent cow Mary Ann of Lancaster 13th was bought. Since that time a well-bred female animal has been bought every year. All the time the best home-bred heifers have been added to the herd, the result being a high-class collection of about twentyfive breeding cows. The sixteenth Earl died in 1909, and was succeeded by his brother, the present Earl, who wisely decided to keep the herd going.

Lady Maud, which is still alive (1919), has been a grand breeder. Her yearling bull Doune Diamond by Diamond Earl was second in the young class at Perth in 1908, and was sold for 150 gs. A full brother was third in the junior class the following year, and was bought by $\mathrm{Mr}$ Wm. Finlayson, Throsk, who took third with him at the Stirling Highland. Doune Maud, calved in 1909, and also by Diamond Earl, was very highly commended at the Inverness Highland in 1911. Doune Marquis, a handsome blood-red calf of great substance by the Saphock Proud Warrior 
$(106,653)$, drew 200 gs. at the Perth sale of 1914 . The old cow's calf of 1915 was Doune Marshal by Dunglass Brilliant $(120,003)$, and he passed into the herd of $\mathrm{Mr}$ Parkin-Moore. Two of his sons were in the Penrith winning group of 1919. At seventeen years of age Lady Maud produced to Dunglass Brilliant the bull Doune Maximum, which was sold to $\mathrm{Mr}$ Gill, Tomich, at $240 \mathrm{gs}$. Impressed with the merits of the Meg Merrilies family, Mr Scrimgeour bought another of that line of breeding at the Mains of Sanquhar draft sale of 1914. That was Lady Hawthorn 2nd by Dunglass Royalist $(108,496)$, from a dam by Hawthorn Champion $(99,098)$. She was in calf to Collynie Grand Knight $(119,549)$, and her calf of 1915 was the famous Doune Grand Knight which was first in his class and reserve champion at the Perth Show of 1917, where he was taken out by $\mathrm{Mr}$ Casares at 1000 gs. Lady Hawthorn 2nd bred a highly promising heifer calf in 1916 which was sold for the States. Her bull calf of 1917 fetched 380 gs. at Perth, and she followed up by producing to Dunglass Brilliant the grand dark roan Doune Majestic, for which Mr Wm. A. Dron paid 1500 gs. She has now a bull calf of remarkable promise by Eclipse of Collynie.

The Rachel family has proved a great acquisition to the Doune Lodge herd. Roan Rachel, bred by the late $\mathrm{Mr}$ Alexander Robertson, Ballechin, was one of $\mathrm{Mr}$ Scrimgeour's highly fortunate purchases. Sired by the noted bull Marquis (84,061), and with the crosses of Captain of the Guard, Athabasca, Cherub 


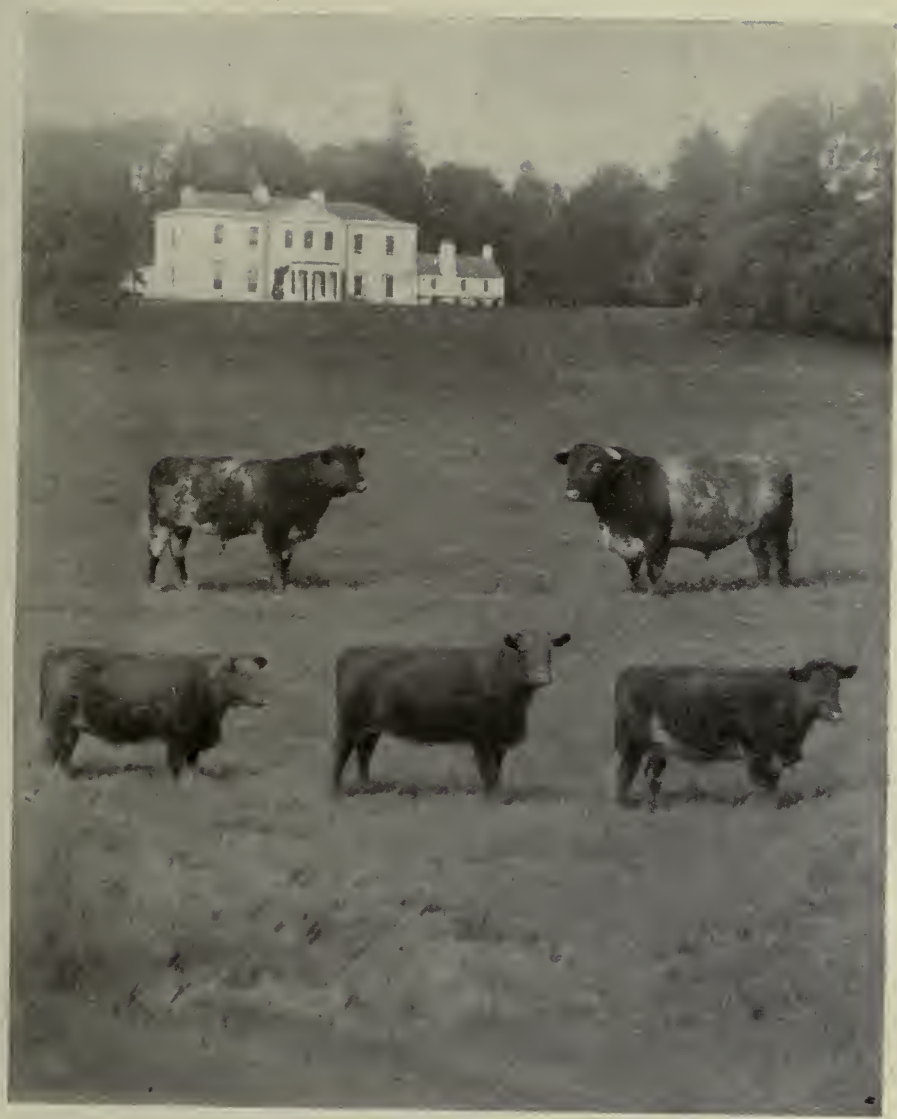

\section{Doune Lodge Group.}

Top (left)-Doune Monarch, second prize, April class, Perth, I920; sold to Captain J. Macgillivray for 3800 gs. Top (right)-Doune Grand Knight $(130,657)$, first prize two-year-old and reserve champion, I917; sold for Iooo gs. Bottom (left $t$-Doune Meg Merrilees 6th; sold for 400 gs. Centre-Doune Broadhooks 5 th ; sold for $550 \mathrm{gs}$. Bottom (right)-Doune Clipper $4^{\text {th }}$; sold for $690 \mathrm{gs}$. 

4th, and Heir of Englishman next in order, she was a roan of the finest character. Her first heifer calf by Diamond Earl was Doune Rachel, the third-prize yearling at the Stirling Highland of 1909, and secondprize cow at Cupar Highland in 1912. Doune Regent, her bull calf of 1911 , took third in the senior class at Perth the following year, and passed to $\mathrm{Mr}$ Casares at $780 \mathrm{gs}$. To Dunglass Brilliant, Roan Duchess produced in 1916 a superb white bull calf, which was sold to Mr Leslie Smith, U.S.A., for 400 gs. The foundation of the Broadhooks was Fairy of Findon 2nd, from Mr Peter B. M'Intyre's herd, and by Conqueror's Heir $(91,314)$. She bred the very handsome red Doune Broadhooks by Diamond Earl. At her second calving the red cow gave birth to twins by Lex of Cluny. One of these, Doune Broadhooks 2nd, was acquired by $\mathrm{Mr}$ G. B. Shields, and she is the grandam of his noted 3300 gs. D.S.O., now owned by Captain Macgillivray. In February 1916 the deepframed, level - fleshed dark roan Doune Baron by Dunglass Brilliant out of Doune Broadhooks took second in the senior class at Perth, and was sold to Messrs Casares for 700 gs. Heifer calves born in 1917 and 1918 have been retained.

The herd has several good-looking Augusta females. The start was with Augusta 119th, a cow bred by Mr R. W. Bell, Coagh, Ireland. That cow's first calf in the herd was Doune Augusta, a beautiful red by Diamond Earl. A heifer calf out of Doune Augusta was exported and another was kept in the herd. She is also the dam of Doune Augustus, which was 
second in the two-year-old class for Mr J. G. Scott, and sold at 1050 gs. to $\mathrm{Mr}$ Kerr of Harviestoun. Goldies are deservedly popular. The foundation of the family at Doune Lodge was the massive roan cow Golden Thistle, bred by Mr James M'William, and by the famous Uppermill-bred red Scotch Thistle $(73,584)$, whose dam was by Dauntless $(54,155)$, and grandam by William of Orange $(50,684)$. Outstanding animals of the Goldie family, bred by the Earl of Moray, have been Doune Goldie 2nd by Proud Warrior, and sold to Mr Kerr of Harviestoun; the deep-framed, well-covered red bull Doune Goldstamp, winner of the Dunmore Challenge Cups at Stirling in 1911, and the stylish roan heifer Doune Goldie 5th, sold to Mr Ian K. Morrison for $420 \mathrm{gs}$. at the Aberdeen sale of 1918. At the Pirriesmill dispersion sale in $1911 \mathrm{Mr}$ Scrimgeour took out of the ring at 150 gs. Rosewater 10th, a typical red member of the Inverquhomery Rosewoods, sire Golden Hero (91,857), and dam by Luxury (74,958). Her daughter of 1914, a beautiful red by Proud Warrior, was retained until she contributed well to the strength of the herd. She was then sold to a United States breeder. Her calf of 1916 was also exported to the States. Rosewater 10th bred a thick deep-fleshed bull calf in 1917 . He took third in the two-year-old class at Perth in 1919, and was exported by Mr A. J. Marshall.

Of twelve families at Doune Lodge, six have been dealt with in the foregoing notes. The more recent additions have been a Clipper calf from Mr William Anderson, Saphock, in 1913; a Lancaster cow at the 
Whiteside sale in 1908; a Butterfly calf from $\mathrm{Mr}$ G. R. Grant, Auchnacree, in 1916; a Rosemary at the Uppermill dispersion sale in 1915; a Lavender calf from Mr George Walker, Tillygreig, in 1917; and a Queen of Rothes calf from Lord Lovat in 1918. From the Tulliallan group at Aberdeen last year $\mathrm{Mr}$ Scrimgeour took a dark roan Nonpareil at 450 gs., and he went to $1000 \mathrm{gs}$. at the Penrith sale for $\mathrm{Mr}$ A. J. Marshall's yearling Secret Sylvia by Broadhooks Diamond $(124,530)$.

Diamond Earl, already referred to, was of the Charlotte Corday family, and his sire was the highly successful Uppermill - bred Diamond Mine. As a breeder of females Diamond Earl was a bull of the first rank. Unlike his sire he was rather upstanding, but he had a very strong back and neat hind-quarters. The Saphock-bred Proud Warrior $(706,653)$, of the Kinellar Rosebud family, and closely related to $\mathrm{Mr}$ George Harrison's remarkable champion cow Warfare, was a red of great substance by the Collynie Proud Emblem $(100,099)$. He had a beautiful head, and although his quarters lacked something in finish, he followed Diamond Earl well as a sire of handsome, richcoloured heifers. He cost 400 gs. at Perth. The Broadhooks bull Dunglass Brilliant $(120,003)$ by Collynie King $(111,336)$, the highest-priced calf at Mr Duthie's sale in 1911, cost $600 \mathrm{gs}$. at Perth. Bred, as his name indicates, by the Messrs Peterkin, Dunglass Brilliant was a short-legged, lightish roan with a thickly covered top. $\mathrm{He}$ was very deep in frame and of remarkable mellowness. Covered with a soft rich 
coat of hair, his touch was perfect. He lacked a little in masculine strength of countenance, but he left grand stock, and the young cows by him are proving excellent breeders. $\mathrm{He}$ was sold in the spring of 1919 to Captain Macgillivray.

A bull of exceptional breed character, conformation, and colour was acquired at Mr Duthie's sale in 1917. That was the red roan Eclipse of Collynie $(136,344)$ by Max of Cluny, out of Collynie Estelle by Knight of Collynie. He cost 1700 gs., but he is likely to prove the cheapest bull ever used at Doune Lodge, as his calves are high-class Shorthorns with heads, bodily shapes, and colours to please a judge. Some of the red cows have been mated with the home-bred white Doune Brilliance by Dunglass Brilliant out of Doune Broadhooks 3rd. Doune Grand Knight (130,657), and the strikingly handsome red Sanquhar Grand Courtier $(139,103)$ by Collynie Grand Knight $(119,549)$, out of Sanquhar Rachel by Hawthorn Champion $(99,089)$, left some excellent calves. The best calf by the Sanquhar bull was Mr Shields' D.S.O. Sold to Captain Fletcher for 750 gs., Grand Courtier won third in the aged class at the Edinburgh Highland.

Some of the land at Doune Lodge is a loam of no more than second-rate quality naturally, but the whole area has been very much improved by good farming. Wild white clover has done well in the rotation pastures. At the steading there is nothing better than the range of bull-boxes with their southern exposure. 


\section{Duchlage.}

At Duchlage Farm, close by the picturesque town of Crieff, Mr George Veitch has for many years successfully combined the dairying and Shorthorn interests. In recent years the Cruickshank cattle have claimed rather more than half interest in grazing and housing arrangements; but the beef breed has justified itself at the shows and sales, while it has introduced those elements of pleasant surprise, partial set-backs, and handsome recoveries which are fortunately so generally associated with well-conducted high-class breeding. With a natural liking for a good Shorthorn, Mr Veitch had strong inspiration from the late $\mathrm{Mr}$ Duncan Stewart. There was no resisting the impulse to found a small herd at Duchlage. Realising that time and money are saved by laying a sound high-class foundation, the tenant of Duchlage went to headquarters at the outset. In 1901 he bought from Mr Wm. Duthie Scotch Marigold 2nd by Spicy Monarch (73,701); Hathaway 4 th by Scottish Fancy $(75,601)$; and Bright Sunshine by Alastair $(78,217)$. Among his subsequent purchases were Heather Beauty by Bonus $(78,428)$, from Mr J. B. Manson, Kilblean; Belladrum Flower 3rd, a Brawith Bud by Myreton (84,199), from Colonel A. T. Gordon of Newton; Ballechin Rosebud 3rd by Marquis (84,061), at the Ballechin dispersion sale in 1909 ; Secret 5 th by Royal Crown $(84,598)$, from Mr John L. Reid of Cromleybank; and 
Lady Florence by Master Millicent (84,080), from Lord Lovat.

Scotch Marigold 2nd was in calf to Rosicrucian $(75,483)$, and she produced Collynie Marigold, which was retained by $\mathrm{Mr}$ Veitch. Marigold 2nd also produced to Bright Star $(74,116)$ the very good bull Lode Star, which won fourth prize at Perth, and to the Millhills stock bull Royal Eclipse $(87,179)$ she had Royal Ordo. Those bulls were exported to the Argentine. Collynie Marigold, put to the Strowan stock bull Montrave Baron (81,740), bred the grand cow Scotch Marigold 5th, which produced to Prince Edgar $(100,036)$ Princess Marigold and Marigold: Princess Marigold was bought by the Earl of Rosebery, and she became the grandam of Lothian Marksman, the Perth first prize winner in the February class, 1919. Marigold was acquired by the late Mr Duncan Stewart, and she bred Pride of Millhills, the champion at the Perth Show of 1918. Those two young bulls, somewhat curious to relate, were sold at 3100 gs. each. Scotch Marigold 7 th by Storm Signal $(110,293)$ is another excellent daughter of Marigold 5th, and she has been retained in the herd.

Hathaway 4th was in calf to Nonpareil Courtier $(90,063)$, and her bull calf at Duchlage was named Scottish Courtier. He was kept for a time as a stock bull, and Mr Veitch parted with him too soon. Heather Beauty was from the same dam as Mr Deane Willis's famous champion White Heather. When Heather Beauty was bought her dam was carrying 
her nineteenth calf. The Bright Sunshine family, which is descended from the Ury Likely by The Pacha, is very well represented at Duchlage. Bright Sunshine 2nd by Scottish Courtier bred to Prince Edgar Bright Sunshine 4th, and that cow gave $\mathrm{Mr}$ Veitch the 5th and 7 th of the line, the latter by Collynie Cruickshank being retained in the herd. The 5th took third prize at Perth in 1914, and was sold for export. The Brawith Bud cow Belladrum Flower 3rd was in calf to the champion Fascinator $(88,569)$, and she had a heifer calf the following season, which was named Belladrum Flower 4th, which grew into a handsome cow. To Prince Edgar she bred Duchlage Fascinator, a Perth fourthprize winner, which was bought by the late Mr Smith of Pittodrie; while to Collynie Cruickshank she calved Duchlage Cruickshank, which passed into the possession of Lady Alice de Rothschild.

Ballechin Rosebud 3rd, an exceedingly handsome broad-backed red with little white, was bred by the late Mr Alexander Robertson. Sired by Marquis $(84,061)$, she proved herself a fine breeder. The best bull out of her was Duchlage Marquis by Prince Edgar, and winner of third prize at Perth. Rosebud, a fine heifer from her by the same sire, was retained in the herd. Welcome Guest and Rosebud 3rd, other two daughters of Cupbearer of Collynie, were sold to $\mathrm{Mr}$ Joseph Shepherd and $\mathrm{Mr}$ Duncan Stewart respectively. Put to Cupbearer of Collynie, Rosebud gave birth to the beautiful bull calf Royal Cup, which took first prize at Perth in 
1917, and was acquired there by Mr Leslie Smith, U.S.A., who has exhibited the bull with success in the States. Gold Cup, a stylish red, full brother to Royal Cup, was sold to Mr Jos. G. Scott, Congalton, who disposed of the bull recently at a very good price for exportation. Behind Marquis, in the Rosebud pedigree, there are the crosses of the great bulls Newton Stone, Scottish Archer, and Gravesend.

$\mathrm{Mr}$ Veitch has a very fine group of Secrets descended from the Cromleybank purchases - Secret 5 th by the grand bull Royal Crown $(84,598)$, one of the best sires used in the North during the last quarter of a century. Mated with Prince Edgar, Secret 5th calved a very pretty heifer named Princess Secret, which was sold to the Marquis of Crewe. On her way south from Perth to Crewe she got a leg broken, but it was well set. At the Marquis's dispersion sale she was bought by $\mathrm{Mr}$ George B. Shields, Dolphingstone. In the Lothians she gave birth to that rare type of a breeder's bull, Rubicon, the reserve champion at Perth in 1918. Secret 7 th, a full sister to Princess Secret, was sold to $\mathrm{Mr}$ Cazalet, and Secret 8th, another daughter of Secret 5th and by Storm Signal, was disposed of privately to Sir John Gilmour, Bart.

Of the bulls used by Mr Veitch, the white Prince Edgar of Mr Duthie's breeding was the most consistently good sire. $\mathrm{He}$ was by the smallish but very thick-fleshed Edgar 2nd of Cluny, out of Collynie Princess 9 th by Bapton Champion $(78,285)$. Prince Edgar left good colours, and all the females by him 
were fine breeders and good milkers. Bright Stone by Godiva Stone $(88,710)$, from Mistletoe by Bapton Champion $(78,283)$, was a handsome bull, but his heifers were disappointing, as they would not breed. Scottish Courtier $(90,063)$, a home-bred bull by Nonpareil Courtier $(79,488)$, out of Hathaway 4 th by Scottish Fancy $(75,601)$, was parted with after too short a trial. The Collynie-bred Storm Signal by Danesfield Storm King $(94,827)$, dam Sittyton Lavender 12 th by Royal Edward $(82,153)$, was a very finelooking roan, but he was prone to leave an undue proportion of whites. The present stock bull, the famous old Collynie Cruickshank, so well known while in the Millhills herd, is proving very valuable at Duchlage as sire of heifers.

\section{DUNMORe Park.}

When the Messrs Jones acquired the beautiful property of Dunmore Park, with its mixed woodlands and roomy enclosures of old grass, it was but natural that they should strike out for fellowship with the Shorthorn men. In the course of two seasons they have founded a valuable herd representing the Clipper, Butterfly, Orange Blossom, Queen of Rothes, Clara, Dunglass Ruby, Broadhooks, Sanquhar Graceful, Rothiebrisbane Myrtle, and Goldie families. Clipper 3 rd, now a three-year-old with her second calf at foot, is a roan of Naemoor breeding by the Dalmeny Lothian Lancer $(132,066)$. A powerful excuse for family fashion could be put forward if all Clippers 
had the high character, faultless symmetry, and mellow quality of this charming heifer. The Butterfly, bred by Mr Charles E. Law, was one of the best of the younger animals offered at the Rothiebrisbane sale of 1918, where she cost the Messrs Jones 450 gs. She is a very handsome red by Brackla Leader $(129,798)$, and her dam was by the Uppermill Lancaster Knight $(116,165)$. Orange Blossom 27th, a light roan of attractive character and good shapes, came from Polmaise, her sire being Pride of Polmaise $(122,082)$. She is from a carefully bred family, with the very best bulls and cows at the top of her pedigree. There is no better bred Queen of Rothes than the four-year-old red of that line acquired from the Messrs Peterkin, and sired by Collynie Coronet $(124,841)$. The Clara and the Dunglass Ruby also came from the Ross-shire herd. Both are reds, and over the five-year-old stage. The Clara is by Collynie King $(111,336)$, out of a cow by the famous Collynie Marshal (105,071), which ended his days in the Edgcote herd; while the Ruby, a cow of great scale and immense heart girth, is by Dunglass Marshal $(111,617)$, out of a cow by the Collynie Royal Banner $(87,152)$. The Broadhooks is a light roan heifer of Mr Wm. Finlayson's highly successful line of breeding, and her sire was the Bessie bull Collynie Golden Boy (130,288). Graceful Princess, a pretty roan heifer by Mr James Durno's noted Collynie Premier $(124,847)$, dam by Scotch Thistle $(73,584)$, was a Rothiebrisbane selection, as was also the beautiful young cow Lady Victoria Myrtle, for which 680 gs. were paid at Mr 
Durno's sale. She is a red by Earl Broadhooks $(108,510)$, her mother being by the Collynie Pride of the Herd $(100,007)$ and grandmother by the Uppermill Diamond Mine $(83,296)$, one of the finest stock bulls of his time. The dam of Lady Victoria Myrtle produced the Aberdeen champion bull of 1917. A valuable addition to the herd was made at the Aberdeen October sale of 1918 in the red Goldie yearling, Lothian Goldielocks, from the Dalmeny herd, and by Auchnacree Laird (134,740). Her price was 720 gs., but she was expected to be in calf to the famous show bull Lothian Lex, now in the Argentine. During the last two seasons the Messrs Jones have made some use of the old white Collynie Silver Knight $(124,851)$ by Knight of Collynie $(112,229)$, out of Collynie Clara 3rd by Danesfield Storm King $(94,827)$, and last season they put the one-year-old red Mains of Sanquhar Foch to all the roan cows and heifers. Foch is by the thick-framed Newton Count $(132,490)$, from Sanquhar Florence 2nd by Sanquhar Eclipse $(117,605)$. Sanquhar Eclipse is by Hawthorn Champion $(99,098)$, out of the Clipper cow Zoe 11th by Scotch Thistle $(73,584)$.

With characteristic vigour the new proprietors of Dunmore Park have erected a commodious and conveniently-arranged set of byres, courts, and boxes for the Shorthorns near the old kennels, which are now transformed into an improved piggery. The owners' intention is to put from 80 to 90 acres of the estate enclosures under a course of cropping. Most of the soil is a strong clay loam of rich quality. 
In connection with Shorthorn breeding, the Messrs Jones are in the happy position of having plenty of space for cropping and grazing should they consider it advisable to work into a fairly large herd. The general oversight of the stock is left very much to Mr Peter Forbes Jones and Mr Tom Bruce Jones, who find at Dunmore Park some pleasurable relaxation from strenuous business.

Apart from its associations, Dunmore has charms of its own. It is a beautiful section of Lowland Scotland at the bursting of the leaves or when autumn gives abundant hints that winter is near. In the open, one of the finest of views is eastwards across the Forth to the Tulliallan policies and round by Kennet.

\section{ECCLES.}

Mr James S. Greig, Master of the Berwickshire Foxhounds, general sportsman, noted athlete in University days, and now a busy man in county public life, is taking up the Shorthorn cause with ardour and discrimination. His beautiful property, with its substantial soil, good shelter, and conveniently set water supplies, is admirably suited for grazing; and the farm buildings, which were mainly intended for ordinary commercial stock, are being modified on the most approved lines for a breeding herd. The aim meanwhile is to work up to a strength of 25 or 30 cows. Mr Greig made his first purchases of Shorthorns at Colonel Munro's dispersion sale in 1914. At that time he took out the Secret cow Silva, and the 
Jenny Lind Princess of Wales. No descendant of those cows are in the Eccles herd. In $1916 \mathrm{Mr}$ Greig acquired some fine heifers - a Ballechin Carnation from Mr Alexander Cameron, Strathtay; a Myrtle by Collynie Golden Dream $(119,545)$ from Rothiebrisbane; a Newton Pauline by Cupbearer of Collynie $(1,149,607)$ from Millhills; and at the Newton sale an Uppermill Bessie by Newton Crystal $(92,658)$, and a Brawith Bud by Grand Champion $(120,527)$. At the Aberdeen autumn sale he added a very pretty calf in the Corston-bred Augusta 136th by the noted Secret bull Schoolmaster $(110,095)$. The selections in 1917 were a Maria heifer by Keep Smiling $(105,835)$ from Mr Parkin-Moore; Lady Ramsden 5th, a fine roan heifer by Edgcote Watson $(111,692)$ from Mr Wylie Hill; a grandly-bred Goldie by Ace of Trumps $(129,015)$ from Mr Paterson, Terrona; and a fashionably descended Orange Blossom heifer calf by Boquhan Pride $(111,114)$, dam by Collynie Golden Prince (111,335), from Mr M'Lennan Duncan of Lethenty. In $1918 \mathrm{Mr}$ Greig bought a yearling Uppermill Bessie, by the Rosebud bull Constitution from $\mathrm{Mr} \mathrm{Wm}$. Craigie; a beautiful Clara heifer by White Knight $(128,848)$ from Mr A. J. Marshall; and a Butterfly heifer calf with the Merlin cross from Mr G. R. Grant of Achnacree, the sire of this calf being Ramsden Rufus (138,717).

The principal bulls used by Mr Greig have been the Harviestoun-bred red Rouge Royal, calved in 1916, and by Cranham Gerome $(119,680)$ out of Winsome Augusta by Primrose Monarch $(106,554)$, grandam 
Ruby Augusta by Choir Boy $(91,238)$; and the yearling roan Pellipar Judge of Lieut.-Colonel Ogilby's breeding, sire Edgcote Regalia (125,396), dam Crystal Bud (Brawith Bud family) by Newton Crystal (92,658), grandam Ruby 47th-Dr Jamieson's line of blood-by Strathmore $(90,264)$. Rouge Royal was kept two seasons, but judging by results he was parted with too soon. The young stock by him are of exceptional promise. The yearling Pellipar Judge shows high character. $\mathrm{He}$ is well grown and deep in flanks and thighs, and his roan with dark head, neck, and legs is what breeders like. Shorthorn men will follow Eccles developments with great interest.

\section{Ednam Mains and Chifton Hili.}

"A land of streams! some, like a downward smoke, Slow-dropping veils of thinnest lawn, did go."

-Tennyson : The Lotus-Eaters.

At Ednam Mains and Clifton Hill Messrs Robert, George, and James Shiel farm about 700 acres of arable land. It is a fine view from the highest field on Clifton Hill southwards across the Tweed valley to the Cheviots, eastwards by Coldstream and westwards by the Floors Castle and Mertoun policies. Sprouton is in the near foreground to the south, and Kerchesters, so long held by the Clay family, is very little farther away, while to the right is the monument to Thomson of 'The Seasons.' Fifteen miles southwards the Messrs Shiel hold two grazings, one of them being the well-known Sourhope, which has 
an elevation of about 700 feet at the homestead, and a range up to 2000 feet, where it reaches the Border. On the way south by quaint Yetholm, with its facts and traditions regarding "gentry gipsies," and its existing suggestions of Spanish blood in dark eyes and well-cut features, one passes by the famous grazings of Attonburn and Mowhaugh up the Bowmont Water. The Hindhopes are away to the south-west, and The Cheviot itself is to the east.

It was in 1904 that the Messrs Shiel set out as Shorthorn breeders. At the Legars dispersion they took out Elegant 2nd from Mr James Nisbet's lot. That was a good-looking female by the Collynie Miss Ramsden bull Brilliant $(56,891)$, and out of Elegant Gwynne, a Mertoun - bred cow which Mr Nisbet acquired from $\mathrm{Mr}$ Torrance of Sisterpath. The following season they bought from $\mathrm{Mr}$ Wm. Hope, Presson, Northumberland, a red cow named Sprightly 21 st, by Prince Bisinarck $(66,041)$, a bull bred by the late Miss Milne of Otterburn. The cow referred to, which was of a strain much bred by the Browells of Apperly, has founded a fairly numerous and generally handsome family in the Messrs Shiel's possession. No special purchases were made again until 1916, when the five-year-old roan Queen Mysie 2nd was secured at the Messrs Milne's sale at Cairnhill, Kincardineshire. Mysie 2nd was by Challenger $(108,033)$. Her roan yearling daughter by Proud Marcus $(112,917)$ and a very good Bellona bull calf by Golden Mark $(115,607)$ were bought at the same time.

In 1918 Adderstone Queen 5th, a red two-year-old 
of a Dryhope family and by the Millhills Count Lugano $(114,855)$, was taken out at Mr A. F. Nichol's Adderstone Grange sale. The breeding herd is now kept at a strength of about twenty cows. Females with bull calves at foot are summered at Clifton Hill, and those with heifer calves and most of the yearlings are sent to Sourhope. The Sprightly family has done remarkably well. As a rule the cows of that family are of tasteful feminine character with sweet heads, smooth flesh, and good milking properties. The Mysies are also coming quite up to their old Shorthorn reputation. There are some exceptionally promising bull calves at Clifton Hill, and the heifer calves at Sourhope are highly meritorious as a collection. The young things are mostly by the red Tarty Favourite, which was by Sittyton Type $(128,244)$, out of Tarty Fanfare 2nd by Collynie Prince Royal $(101,834)$, and the roan Orange Blossom Dunglass Courtier by Polmaise Royal Baron (132,732). Some very fine heifers are coming forward.

At Sourhope the Shorthorns have to do some hillclimbing, but they thrive well at the burn-sides and well aloft, and finish the season in fine condition. Reference has been made to the sires of the young stock. One of the best yearling heifers in the herd is a Mysie by Rouge Royal, which is referred to in connection with the Eccles and Darlingfield herds. Farther back, superior stock were left by the red Queen of Rothes, bull Balnakyle Regent by Crystal Knight (136,009); the Crieffvechter Crusader $(125,048)$ by Cupbearer of Collynie; the Heatherwick Clipper 
King $(108,193)$; and the Tillygreig Royal Hope (139,071). During the past season use has been made of the exceptionally well-bred Queen of Rothes roan, Rothes King, by Collynie Royal Lavender (114,770). Messrs Shiel have a very interesting herd.

\section{Greenlees.}

Some good Shorthorns have been bred on the exposed farm of Greenlees, near Kelso, during the last twenty years, by Messrs Adam and Robert Riddell. Mr Adam Riddell, the surviving brother, states that the foundation of the herd was laid with two cows bought in 1900 at the then Capt. Oliver's Hoselaw sale. The cows were Maybloom, formerly owned by Mrs Hodgson Huntly of Carham Hall, Northumberland, and sired by Chieftain $(54,344)$; and Victorina by Captain Hope $(66,778)$. In 1910 another cow was acquired at the late $\mathrm{Mr}$ Elliot's Clifton Park sale. That was the Alnwick Park-bred Selina's Fancy by Pride of Freedom $(73,241)$. The three cows now referred to bred remarkably well, and their female descendants formed a pretty herd of good-headed, deep-milking animals. The principal bulls used in the herd have been Landsman (83,847), Satellite (90,044), Sailor Prince (93,318), Roan Benson (100,301), Midshipman $(99,643)$, Broadhooks Chieftain (101,301), Lipwood Choice (126,516), Halsall Reliance (131,331), and Mahogany $(137,789)$.

Greenlees is a high-lying, mainly north-facing 
farm, ranging from 500 to 900 feet of elevation above sea-level. It is open to the blasts, and most of the arable land is of second-rate or worse quality. The farm has some useful rough grazing well up the slopes, and the highest part on Linton Hill merges into heather. Stock bred on the farm naturally thrive best under the grazing conditions.

\section{Harviestoun.}

"The secrets held by the creatures nearer than we To earth he sought, and the link of their life with ours."

-Meredith's Melampus.

It is sometimes held that strength is lost in diversity, or that specialism is endangered by the play of one man's mental forces on several departments. Yet here we have Mr John Ernest Kerr of Harviestoun as a practical rebuke to one of the standard texts. From the foundation of a very few female animals he has ere his early prime built up what experts in general claim to be the finest Aberdeen-Angus herd in the world; he is in the front rank with two breeds of horses, at least three breeds of dogs, and a good many varieties of poultry and pigeons; he is a wonder in cavies, and he is never without surprises in other departments. Then to crown all, he is a most usefully endowed generalpurpose farmer. When Mr Kerr took up the Shorthorn cause about thirteen years ago, those who knew him predicted that he would come to distinction in this as in other lines. His course has not been with- 
out its small crops of difficulties, but the honours are with those who laid down the policy of "Wait and see."

Practically all through, Mr Kerr's Shorthorn female selections have been calves. He began in 1907 with five calves from Mr Wm. Duthie. Only a Princess Royal is now represented so far as that group is concerned. She was by Bapton Favourite $(76,080)$, out of Princess Royal 65th, the dam of the highest-priced yearling and two-year-old at the Uppermill dispersion sale of 1905 . In 1908 he acquired a Butterfly and a Victoria from Sir Hugh Smiley and a Clipper from Windsor. Two years later he added a Secret from Mr James Durno, then of Jackstown, a Nonpareil from Mr James Davidson, and a Violet from $\mathrm{Mr}$ George Argo. From 1911 to 1914 he bought several high-class females - an Augusta and a Clara from $\mathrm{Mr}$ A. J. Marshall, a Goldie from the Earl of Moray, and a Lavender from Mr Duthie. The Goldie was by Proud Warrior $(106,653)$, out of a Diamond Earl $(98,591) \mathrm{cow}$; and the Lavender was by Collynie Commodore $(105,066)$, the sire of the famous Knight of Collynie $(112,229)$. Two years ago he bought one of the most beautiful Rosewoods in Scotland from Major Maclean of Drynie. His principal additions since 1918 have been an Augusta from Balthayock and a Clipper of the Cinderella line from Westside. $\mathrm{He}$ is now fairly on his course with a lot of distinguished-looking cows and heifers. Thus far the strengthening of the herd with the best of its own heifers has been comparatively slow, as there has been 
a very distinct sway to bull-breeding. Mr Kerr's aim in the meantime is towards a score or so of breeding cows, because the sum total of "followers" or young stock is apt to be fairly large in these exporting days.

Very fine bulls have been used in the herd. The first one, of some note, was the dark roan Prime Favourite $(106,546)$, bred by Mr W. A. Dron. Sired by the Millhills stock bull Proud Favourite $(84,420)$, Prime Favourite had been used for four seasons by the late Mr James M'William, Garbity. An equally well-known bull followed in the white Cromleybankbred Regent $(106,754)$ of the Roan Lady family and by the famous Royal Crown (84,598). Regent was most effectively put to stock use by Mr John Gill in Cumberland, and it was from results there that $\mathrm{Mr}$ Kerr made up his mind to buy him. The Cromleybank bull was succeeded by the dark roan Sanquhar Grand Gallant (133,421), a massive level Clipper, inclined to be rather round in horn, but mellowfleshed and rich in hair. $\mathrm{He}$ was by Hawthorn Champion $(99,098)$, out of a fine cow by Collynie Grand Knight $(119,549)$. The blood of those two Collynie bulls has been still further introduced during the last two seasons through the recently-exported red Doune Augustus $(142,054)$ by the Perth reserve champion Doune Grand Knight $(130,657)$. Sorne of the darker coloured females in the herd have been mated this season with the handsome home-bred white Nonpareil Duke by the Sanquhar sire. This white was third in the January class at Perth, where he 
was bought for 1150 gs. by Mr A. J. Marshall, who is to export him ere long.

Mr Kerr has about 1400 acres of arable and lowground grazing land in his own hands. That extent is in seven farms. The best soil is a rich brown loam, falling away gently towards the valley near Harviestoun Castle, which has its back to the green Ochils, and its front to the sunny south. There are rolls, gentle heights, and scooping howes all over the farms, and the soil ranges, for the most part, from a moderate quality of loam over drift and soft sandstone to stiff clay. Aberdona, on which the Shorthorns are kept, is nearly all over a clayey subject which becomes hard in a droughty summer. In extent it is over 300 acres. For convenience in working, airiness, and comfort, the steading is one of the very best, and the bull-boxes outside the main block of buildings are on the most approved modern plan. Shorthorn breeders are following Harviestoun developments with very great interest.

\section{Hoprig Mains.}

The gallant young soldier who was known in the great war as Capt. Tom Blair of the Royal Scots, eldest son of Mr Thos. Blair, Hoprig Mains, on Lord Lamington's estate, East Lothian, has been laying the foundations of a well-bred herd, and the likelihood is that he will hive off when a suitable opportunity occurs. Meanwhile he is happy at home in watching farming operations on a fine holding, and 
in noting the development of his favourite breed of cattle.

At the Aberdeen October sale of 1919 he bought Clara of Durno, a very showy white six-year-old by Golden Mascot $(95,330)$, a grand breeding bull by Bapton Favourite $(76,080)$, out of a Goldie cow by William of Orange $(50,604)$. Clara of Durno has the favourite William of Orange cross further down in her pedigree. She is thus of the branch which has been so popular ever since the W. S. Marr days, and is a spring calver to Cudham Fame (vol. 65). Brawith Bud and Bessie, heifers from $\mathrm{Mr}$ W. A. Scott Clyne's, were both in calf to Nigel of Cluny (116,747), the sire of $\mathrm{Mr}$ George R. Grant's highpriced lots a few years ago. The Brawith Bud, Golden Daffodil 2nd by Barrogill Crest $(129,525)$, is of the Golden Wreath branch, and her dam was by Silver Crown $(117,733)$. Bessie of Barrogill by Towie Barclay Statesman $(133,980)$ is of the best Uppermill line, with the crosses of William of Orange, Cherub 4th, and Heir of Englishman, and her dam had a double cross of the blood of Cornelius $(66,864)$. She has produced a pretty roan heifer calf. At the Linksfield sale Capt. Blair took out of the ring at 300 gs. the red yearling Cullisse Marion 11th, bred by the late Mr John Gordon. She is by the Crieffvechterbred Economist (136,346), and is of the fine old Aberdeenshire Matilda family, which produced the Windsor champion heifer of 1915 . In calf to the splendidly-bred Lavender bull Inverness Patrician by Collynie Violet Star $(135,830)$, she should pro- 
duce something fit to take high rank. At the Linksfield sale Mr A. J. Marshall paid 680 gs. for Patrician. Another selection at Colonel Johnston's dispersion was made by the Hoprig Mains junior in Sweet Mina, a pretty red calf of the old Rettie Meg Merrilies family. Sired by the 3000 gs. Lothian Mario $(137,713)$, one of the finest bulls of the day, she cost 200 gs.

\section{Kaimflat.}

On the pleasantly-set 300-acres farm of Kaimflat, with its useful strength of soil, good roads, and thorough equipment in buildings, Mr Robert Graham, one of the busiest men in the Kelso district, has been gradually building up a Shorthorn herd, his aim being a muster of about twenty breeding cows. His set-off was at the Buccleuch dispersion sale of 1908 , where he took out a Heather Bell by the Clunes-bred Levanter $(89,068)$. At the Newton sale in 1913 he acquired a fine breeder in a Rubyhill cow by R.N.D. $(93,110)$. She was first in the milking class at the Royal Northern and at the Border Union. Two-yearold and yearling daughters of the old cow bred at Kaimflat show a great deal of breeding, and should prove valuable as matrons. In 1913 also Mr Graham bought from Mr Inglis of Pirntaton, Gala Water, a handsome cow and good breeder in Sweet Maid 3rd by Strowan Duke 3rd $(104,114)$. Her daughter, a roan of high-class character, took fourth as a yearling at the Hawick Highland Show. The sire of 
this female was Mr A. J. Marshall's Stage Pirate (114,320).

Recent purchases include Butterfly, Mayflower, Heatherwick Bella, Matilda, and Sanquhar Graceful, heifers with the very best top-crosses. The Butterfly, a very good-looking roan, was bred by $\mathrm{Mr}$ Williamson, Auldtown of Carnousie, and is by $\mathrm{Mr}$ Wm. Duthie's Merry Courtier (116,550); the Mayflower came from the herd of Mr Allan M. Douglas, and is by Bessbrook (124,300); the Bella and the Matilda were acquired from Old Craig, their sires being Crystal Gift $(130,475)$ and Chief General $(124,738)$; while the Graceful was from the select little herd owned by the late Mr John Watson, Kirkwood House, Strathaven. The sire of the Graceful was Boquhan Augusta Chief (129,746). This heifer, a red two-year-old, has produced a very pretty roan heifer calf by the Wester Lovat Proud Waterloo, a massive, level, dark roan, calved on the last day of March 1917 by the Saphock Proud Nonpareil (122,232), out of a Lady Waterloo cow by Kilblean Stamp $(88,978)$. Mr Graham has also used to some extent a grandly bred Augusta yearling-the red Fairlawne Gainsborough from Mr Cazalet's famous herd, sire the Pirriesmill Esmond (111,713), dam Augusta Goldie by the Collynie Pride of the Goldies (100,006), grandam by Orangeman $(84,263)$, and great-grandam by Waverley $(68,072)$. Augusta Goldie, bred at Fingask, cost 300 gs. at the Aberdeen sale in 1910. Pride of the Goldies was by Pride of Avon (86,878), out of a dam by Scotch 
Thistle $(73,584)$, probably the most impressive sire ever used by the Messrs Law.

\section{KEIR.}

In the thirties and forties of last century $\mathrm{Mr}$ Archibald Stirling of Keir won many prizes with his Shorthorns at the Highland Society and Scottish Central Shows. He kept good cattle, but evidently he could not be troubled with registration. The herd was sold off about 1848, and no record of its breeding was preserved in the estate office. It was Sir Wm. Stirling-Maxwell, Bart., who brought Keir into world-wide fame for Shorthorns and Clydesdale horses. Sir William and his expert agent, Mr Alexander Young, were in touch with the owners of the best herds and studs in the country, and they knew their own minds. A generation ago Shorthorn breeders and admirers in Stirling, Perth, and the Lothians were wont to speak enthusiastically of such Keir favourites as Grandiflora, Carrara, Young Carrara, Drapery, Chemisette, Flora, Rosanna, Princess of Cambridge, Miss Nightingale, Picotee, Laura Bell, and Flower of the Rhine, the last named coming from Aylesby at 510 gs. Such bulls as Blencow $(11,182)$, John o' Groat $(13,090)$, Hiawatha $(14,705)$, Royal Butterfly 11th (20,719), Allan, Fandango, and Forth, were also passed in review by the older men when Keir was the text. Among the cows the Groats, also much associated with Cambushinnie, were not excelled by any family. Sir William 
founded his herd in 1850 or 1851 with Booth cattle or Teeswaters, as they are termed in the Keir stockbook. The first home sale was held in 1855, and the intention was to have an annual disposal of spare stock, but pleuro-pneumonia prevented a sale in 1858, and foot-and-mouth disease did the like in 1870. Between 1851 and 1855 there were about a dozen breeding cows in the herd, and the usual number of heifers. A private herd-book started in 1855 contains in all the names of 115 cows.

The private register shows that 372 live calves were dropped between 1852 and 1881, the year of the dispersion sale. The first sire used in Sir Wm. Stirling-Maxwell's herd was Blencow $(11,182)$, bred by $\mathrm{Mr}$ Troutbeck, and of the Gwynne family. Leader (11,074), bred by Mr Nicol Milne, Faldonside, followed. In 1855 the famous Farnley Hall John o' Groat $(13,090)$ was acquired, and he was successfully used for three years. Then came the Athelstaneford Hiawatha (14,705), which had won at the Highland Show of 1857. Several sons of John o' Groat were used in the herd during the sixties. Inbreeding was practised rather freely for several years, but towards the end of the decade first noted, and in the early seventies, the bulls Forth $(17,866)$, Royal Butterfly 11th $(24,235)$, and the Killerby Banner Bearer $(27,907)$ were extensively used. They were followed by the notable Aylesby Fandango (33,879), which cost 700 gs. at the Torr dispersion sale of 1875. Royal Butterfly 11th was in the herd from 1864 to 1871, and Fandango was kept on until the 
disposal of the herd in 1881, when he was acquired by Mr J. Peel, Clitheroe. Count Broughton $(39,639)$ was the sire of most of the calves dropped during 1879-81. Fandango, for all his breeding and early reputation, was not a success as a breeder. John o' Groat was accounted the best sire by far ever used at Keir. He was a beautiful red, wonderful for symmetry, touch, and breeding appearance. His sire was Bridegroom $(11,203)$, and his dam was Juliette by Captain Edwards (8929). He was champion at the Salisbury Royal and the Glasgow Highland, and in returning home from the latter he took pleuropneumonia and died. The champion Forth was a light roan of immense scale and perfectly even in flesh. Facing one or standing three-quarters on, he was magnificent, but when one stood behind him his quarters looked comparatively light, as he had such enormous development in front. He owed something to his home-bred sire Florist $(16,064)$, and very much to his dam Anna Rose by John o' Groat. So far as tested he proved a very good sire at Keir, but at Sittyton his stock were somewhat irregular in merit. Keir Butterfly was a very handsome show bull, and as a sire he had more than average success.

For thirty years the herd had a great breeding and prize-winning career. From twenty to twentyfour cows were kept as a rule, and the calves were pail-fed. The annual sales were the means of distributing stock of the finest breeding all over the kingdom, and a good many had their first Shorthorn enthusiasm at Keir, as there was inspiration in talks 
with Sir William and Mr Young. The Baronet died in 1878, and the herd was then very much reduced in numbers. As already noted, the dispersal sale was held in 1881.

The Groat family, which has come into fame in recent years, may be said to have had a Southwick origin. Sir William bought Mr Mark Stewart's Alma by Baron Ravensworth (7811). To John o' Groat Alma produced Jeannie Groat, which in her turn bred Amelia Groat by Magenta (20,253). Amelia Groat was sold to Mr John H. Dickson, Cambushinnie. At one time the Keir Mysies did not have more than a local reputation, but they came to be very much admired at Kinkell, and during the last twenty years they have proved themselves the best cattle at Crieffvechter. The family is of Ladykirk origin, but there is no record as to where Sir Wm. Stirling-Maxwell bought his foundation animal of this line of breeding.

The existing herd, owned by Brigadier - General Archibald Stirling, was started in 1898. Mr James Rodger, the estate agent then, bought at Fingask sale the cow Velvet Jewel, which proved a grand breeder, although her pedigree could not be extended to meet the Argentine herd-book regulations. She became the dam of a very handsome show bull and fine-breeder, Keir Jester $(86,287)$, which was exported to Uruguay. At the Fingask sale Mr Rodger made highly fortunate selections also in the Miss Ramsden cow Meadow Shepherdess, and in Craibstone Beauty and Craibstone Beauty 8 th, of the same family as Mr J. Deane Willis's great champion White Heather, 
for which a bid on behalf of Keir came second last. Further purchases were made at Mains of Murthly and Aikbank, and at the Pitcur dispersion a Marchioness and a Groat were taken out. The former left no female stock, but the latter is now represented in the herd by two exceptionally fine cows, Mistress Groat by the Ballachraggan Royal Master (110,019), and her daughter by the Old Craig Proud Napoleon $(122,231)$. In 1903 a heifer of the old Keir Mysie family was bought from Miss Lathom, Strathord, and her first two calves by Keir Jester brought 220 gs. and 105 gs. at Perth.

At the Insch Joint Sale in 1904, a Marigold cow and a Jilt heifer calf were secured. These proved prolific breeders. The Jilt left 14 calves. In 1905 and 1906 a heifer of the Julia branch of the Dairymaids and heifer calves-Broadhooks 2 nd and Beaufort Queen 2nd, both by Master Millicent-were purchased from Lord Lovat. A daughter of the Julia left 14 calves in ten years. The Broadhooks left no female descendant, but Queen 2nd is well represented in the herd. At the Aberdeen October sale in 1908 a Clara heifer was secured from the Saphock group, but she proved a bull breeder. From Minmore at the same time there was taken a cow of the Sittyton Dora family. That cow left some grand females.

The Augustas in the Keir herd have been very greatly admired. They are descended from a fortunate purchase at Perth in 1909-Augusta 112th by Newton Star $(103,183)$. A Charlotte Corday heifer calf was acquired at Aberdeen in 1913. After 
leaving two females in the herd she herself was sold to Messrs Carpenter \& Ross, U.S.A. A Broadhooks heifer acquired from Mr D. H. Moore, Drummond, in 1915, has so far produced bulls. In $1917 \mathrm{Mr}$ Rodger made valuable selections in a Cloichfoldishbred Lady Dorothy heifer and a Montrave-bred Clipper heifer calf. The Lady Dorothy is by the great stock bull Keir Quartermaster $(120,896)$, a son of Edgar 2nd of Cluny and out of the Queen of Rothes cow Beaufort Queen 2nd, while the Clipper is by Butterfly Royal $(130,032)$.

A note may be taken of the best breeding bulls used in the herd. St Clair $(79,884)$ of the Undine family and by Merry Archer $(67,477)$; Bridegroom (82,944), a Jenny Lind by Mercury; and Myrtle Archer $(84,200)$ by Archer, were specially successful as breeders of females. Keir Jester $(86,287)$, of the Strawberry line and by Myrtle Archer, might have had a longer reign. It will be seen that three of these bulls just noted brought in the blood of the famous Scottish Archer $(59,893)$, which was much inbred to Champion of England.

The Brawith bull Lord Elgin $(89,117)$ was a very fine heifer-getter. Extensive use was not made of the Jackstown Lustre bull Baron's Pride $(97,986)$, but he left some excellent animals. Edgar 2nd of Cluny $(91,611)$ was an extraordinary success on the female side. His cows at Keir are a grand collection. Collynie Gondomar (124,843), a Golden Drop by Max of Cluny, also proved a first-rate sire. Polmaise Star $(138,478)$, a light roan Lady Dorothy by Lex 
of Cluny $(109,170)$, has been leaving some beautiful calves, but a proportion are too much of his own shade of colour. The finest-looking bull ever used in the herd is the red roan Collynie Nonpareil Knight, the first calf on Mr Duthie's catalogue in 1918. $\mathrm{He}$ is by Knight of Collynie (112,229), out of Gainford Nonpareil by Keystone of Cluny $(105,856)$.

The Keir proprietor has never favoured summer showing to any extent, but he has actively supported the fat-stock exhibitions, and has had many successes with various breeds and crosses at the Scottish National and Smithfield Shows. Keir homestead is one of the best, and the farm-land, all over red sandstone, grows grain and general crops of superior quality.

\section{Kippentoss and Kinpurnie.}

In the days of the late Colonel Stirling of Kippendavie, Mr A. H. Anderson, the active-minded estate agent, managed a fine stud of Clydesdales and a noted herd of Aberdeen-Angus cattle on the home farms, but since those times the public life of his district and the forwarding of his sons' agricultural and stock-breeding affairs have taken up a good deal of Mr Anderson's energies. His eldest son, Lieut. John W. Anderson of the 7th Cameron Highlanders, a brilliant student of the Glasgow Technical College, fell in the great war. The second son, Mr A. $\mathbf{M}$ 'Kinlay Anderson, is tenant of the excellent farms of Kinpurnie and Templeton, in the Howe of Strath- 
more, while the youngest, Mr Patrick Stirling Anderson, holds Kippenross Home Farm, near Dunblane. Mr A. H. Anderson took over the farm just referred to in 1910, and shortly afterwards he bought Carnation, Clara, and Waterloo heifers from the Earl of Moray. In 1915 he added a Jilt by Keir Broadsword (116,031) from Brigadier-General Stirling's herd, and a Miriam of Newton from the herd of Major Graham Stirling, and by Strowan Claverhouse $(110,334)$. He acquired a Lady Dorothy and a Wimple the same year from Ballachraggan. There are over forty head of those families now on Kippenross farm.

The principal bulls used have been Proud Warrior $(106,653)$, the noted Saphock-bred red which was for several years in the Doune Lodge herd; and the Princess Royal Garbity Primate, a short-legged red by Edgcote Flatterer $(125,374)$, out of a Pride of Avon cow. Mr Anderson had also the privilege of sending cows to the Doune Lodge stock bull Dunglass Brilliant $(120,003)$. There is great promise in the young stock by Garbity Primate.

Only a beginning has been made with a Shorthorn herd at Kinpurnie, near quaint Newtyle, but additional purchases are likely to be made at the earliest opportunities.

\section{LAWHILL.}

Those who have attended the principal Scottish Shorthorn sales of the last few years can testify that the enterprising West Perthshire agriculturist and 
stock-breeder, Mr Peter Wilson, Lawhill, is not easily shaken off when he begins to bid for an animal which is to his liking. Mr Wilson, who had the Shorthorn stimulus from the late Mr Duncan Stewart, began to lay the foundations of a first-class herd in 1914. He then acquired from Mr Wm. C. Hunter of Arngask a. Bellona cow and a Miss Ramsden heifer. About the same time he acquired from $\mathrm{Mr} \cdot \mathrm{Wm}$. Craigie the Clipper cow Montrave Ethel, bred by Sir John Gilmour, Bart. At the Whittingehame sale in 1916, Mr Wilson took out at $100 \mathrm{gs}$, for Mr T. L. Anderson of Damside, the very pretty roan heifer calf at foot of Goldie 32nd, which then passed to Naemoor. Mr Wilson made several purchases for $\mathrm{Mr}$ Anderson, but, after a short trial, the owner of Damside found too many difficulties in keeping blackskins and Shorthorns on one farm. Mr Wilson recently made a sporting offer for his neighbour's Shorthorns, and he had a transfer to Lawhill of the Whittingehame Goldie, a Heatherwick Clipper heifer which had cost 290 gs. as a calf at Aberdeen, a Clunes Nonpareil, whose original price had been 900 gs., and a very fine Millhiils-bred Princess Royal by Cupbearer of Collynie $(114,960)$.

To these Mr Wilson added a Queen of Rothes yearling from Messrs Sharp, Rothes, at 260 gs.; a Montrave Butterfly heifer calf by Duchlage Secret $(125,262)$, a son of Cupbearer of Collynie ; a Broadhooks calf from the Messrs Peterkin; a Bessie and a Rosebud from Mr Craigie. Attending Mr James Durno's sale at Rothiebrisbane in 1918, Mr Wilson 
took out of the ring, at $700 \mathrm{gs}$, the beautiful roan four-year-old Cinderella Clipper named Clipper Garland by Golden Sittyton (105,643), and the very handsome dark roan Augusta 109th, of like age, by Royal Clarion $(117,457)$, the price in this instance being 510 gs. From Messrs Rose, Ballechin, Mr Wilson recently acquired five cows-Rosewood 82nd by Brave Augustus $(107,996)$; Ballechin Lancaster 2nd by Collynie Golden Baron (125,733); Ballechin Mysie by Ringmaster $(109,913)$; the Uppermill-bred Marigold 70th by Prince Palatine $(117,061)$; and Fair Dorothy by Cruickshank Favourite (114,941). To these there fall to be added two lines of Bellonas from Cairnhill and Boquhan-a Mysie from Crieffvechter, and a magnificent red Miss Ramsden, bred by the late $\mathrm{Mr} \mathrm{A}$. Macgregor, Currochs, Crieff, and by the Millhills stock bull Collynie Cruickshank (105,068). He made important selections at North Loirston sale in the beautiful red cow Lavender 65th (1010 gs.), and her handsome red bull calf (150 gs.). The cow is by Royal Charter $(84,585)$, from a dam by Carabineer $(104,976)$, both of these being Collynie bulls, and her grandam was by the Sittyton Captain of the Guard $(58,596)$. The calf is by Collynie Master Lavender (141,710), for which Mr Stephen Mitchell's representative paid 3500 gs.

At the outset Mr Wilson had the use of the Millhills stock bulls. That was of immense benefit to him. He has now the foundation for a great herd. Breeding and merit are blended in a way to win enthusiastic praise from any good judge. Thirty cows 
and heifers calved down in 1920. His stock bull is the Millhills-bred Roan Rosebud by Collynie Bright Star $(130,287)$, out of Rosebud 3rd by Cupbearer of Collynie (114,960), grandam Ballechin Rosebud 3rd by Marquis (84,061). This young bull, which was fourth at Perth in spring, has a beautiful head and excellent hindquarters. Mr Wilson farms in all about 1000 acres. Lawhill, on which he resides, extends to about 300 acres. Then he owns the adjoining Clathybeg, and tenants Mill of Gask.

From Lawhill farmhouse there is a spacious and noble view down Lower Strathearn. On a sunshiny autumn day it is one of the most striking outlooks in a countryside which is singularly rich in landscape revelations. To the south the eye rests on the greenish rounded Ochils, and when one turns to the northwest and north, the rugged Grampians show their own characteristic greys, russets, and dark purples. Lawhill falls away somewhat sharply to lower levels. Its nature is a good general-purpose loam, and the tenant makes the most of it.

\section{LAWTON.}

There is probably no busier man in Strathmore than Mr Wm. Henderson of Lawton, Coupar-Angus, as he farms about 500 acres, manages a neighbouring property, and overtakes a large amount of public duties. A thoroughgoing worker, he believes in throwing his full energies into any business he takes up, let it be the breeding and feeding of stock, cultivation of land, the in- 
terpreting and application of local government enactments, or the improvement of roadways and water supplies. He founded his Shorthorn herd thirteen years ago by purchasing at the Oliverburn sale three cows owned by the representatives of the late "Laird Robertson." One of those cows, a Meg Merrilies, proved a very fortunate investment, as she bred twelve calves without a break. In 1908, Mr Henderson acquired a pretty heifer calf, Strowan Buttercup 26th, from Major Graham Stirling. That calf developed into a handsome true-breeding cow. At the Buccleuch dispersion in the same year he bought Bright Lass, a fine yearling of the same family as Rose of Collynie. In 1909 he attended the Ballechin dispersion sale, and bought at an easy figure Lady Dorothy 41st and her heifer calf by Tom Bowling $(97,441)$, and from those two he has bred a large number of first-class good-milking females. From Phingask he acquired the same autumn a member of the comparatively scarce Snowfly family, and one of the best cows in the herd at the present time is of this line of breeding. A valuable addition to the herd was made in 1913 in Doune Goldie 3rd, which unfortunately was lost after producing her second heifer calf in the herd, Her daughters are most distinguished-looking cows. $\mathrm{He}$ made no purchase of consequence again until 1914, when he took a couple of very fine white heifers from Redgorton. These were Daffodil 27th by Redgorton Augustus (112,995), and Bertie Lincoln, a Miss Ramsden by Pride of Livet $(109,678)$. The latter was lost unfortunately after giving birth to a fine 
heifer calf. At the Uppermill dispersion in 1915 he selected the handsome young red cow Scotch Beauty 10th of the noted Kilblean Beauty family, and by the great stock bull Royal Leader $(103,727)$. She was in calf to Prince Palatine $(117,061)$, and the result was an excellent heifer calf. In 1915, also, he acquired a very good Bessie heifer from Mill of Wartle, and Butterfly Queen 7 th from Woodend. Clipper Fancy, a pretty white, was bought from Heatherwick the following year. At the dispersion of the stock owned by the representatives of the late Mr John Gordon, in 1918, Mr Henderson secured one of the greatlyadmired Secrets in the white heifer Cullisse Symmetry, and he also took a Brawith Bud.

The first bull used in the Lawton herd was Boquhan Champion $(104,838)$, a Clara by Proud Monarch $(92,961)$, dam by Orton $(79,509)$, grandam by Archer Royal (71,943). Boquhan Champion was retained five years. Much of the success of the herd is due to that bull. His females were of a uniformly high-class order, fine milkers, and of a distinct type. The Rosehaugh - bred Rosemere $(122,530)$ was then used to a limited extent, and he left some very good heifers. A bull which had a striking influence on the herd was selected in 1913. That was the red Dunglass Chieftain $(115,188)$, which was kept for six years. As a sire of females that bull was one of the best of his time. He left beautiful heads, smooth mellow-touching frames, and he backed the Boquhan bull on the milking side, while his colours always ran to rich roans and reds. $\mathrm{He}$ was by the 
famous Collynie Marshal (105,071), from a Brawith Bud cow by Jim Sidey $(99,230)$. In 1917 a limited use was made of the Woodend Diamond Favourite, a roan Queen of Rothes bull by the noted Brave Marquis $(119,158)$ which has bred so many winners for Mr Crombie. This Woodend bull was put to the Dunglass Chieftain heifers. At Mr Duthie's sale in $1917 \mathrm{Mr}$ Henderson bought two young bulls by Knight of Collynie. These were Collynie Crossbow $(141,700)$, a dark roan Crocus with exceptionally fine top-crosses-Collynie Marshal, Royal Edward, Golden Star, and Prince of Fashion-and Collynie Bachelor $(141,695)$, a red Butterfly from a dam by Solid Silver $(87,418)$, grandam by Candahar $(78,522)$. Crossbar, which cost 520 gs., has developed into a grand bull with a beautiful head and remarkably good hindquarters. He has been used to a considerable extent, and his calves are of great promise. Collynie Bachelor was put to some of the lighter-coloured heifers. $\mathrm{He}$ was sold last spring. Last year $\mathrm{Mr}$ Henderson acquired from the Earl of Rosebery what some good judges consider to be one of the best white bulls in Britain-Lothian Brigadier, a Broadhooks by Edgcote Masterpiece $(115,277)$.

In $1917 \mathrm{Mr}$ Henderson had fifty calves from fortynine cows and heifers, a result which would be difficult to equal anywhere. His aim in future will probably be towards a breeding strength of thirty to thirty-five cows. Lawton itself, which he owns, has an extent of about 240 acres, while the neighbouring farm of Leaston, which he holds on lease, runs to 270 acres. 
So far, Leaston has been used for grazing and feeding commercial stock, but if necessary it can form a very good summer outlet for the Shorthorn heifers. Hitherto Mr Henderson has had no difficulty in disposing of his surplus heifers privately. His best have gone mainly to the Argentine and the United States. He has a herdsman of great experience and enthusiasm in John Mackie, a born judge of a Shorthorn.

\section{LONGNIDDRY.}

The farm of Longniddry is pleasantly situated on the shores of the Firth of Forth, about thirteen miles east of Edinburgh. In recent years its acreage has been cut down for building schemes, the erection of a sugar-beet factory, and other developments. The farm has now an extent of fully 370 acres, and Mr James Shields, the present holder, has 35 acres of grazings in the policies of Gosford House, the residence of the proprietor, the Earl of Wemyss. It was to Longniddry that the late $\mathrm{Mr}$ Shields came in 1904, after making over his interests in Dolphingstone to his son, Mr George Bertram Shields. Longniddry soil is a sharp sandy loam, admirably adapted for general cropping, and with a special reputation for potatoes and grain, in both of which a good seed trade has been established. The steading is an excellent one, with a roomy airy byre, and some very good out-and-in boxes for bulls, and it has the great advantage of being only a quarter of a mile from the railway siding. The 
threshing-mill is driven by an oil-engine, but there is water-power for breaking, bruising, chaffing, and cutting. The late Mr Shields was a noted breeder and feeder of commercial cattle, and he won many distinctions at the Scottish National, Ipswich, Birmingham, and Smithfield Shows. The old gentleman, who had made a start with a few Shorthorns in $1913-14$, died in the latter year, and as his son, Mr James Shields, joined up early in 1915 for the Great War, the pedigreed animals were disposed of. At the end of $1917 \mathrm{Mr}$ Shields was invalided from France, and was allowed to resign his commission. After settling down to farm life, he attended the Cullisse and Mounteagle dispersion sales and secured a finely-bred Lady Dorothy cow, Mounteagle Dewdrop 3rd, by Brora (124,553), and in calf to Golden Bugler $(142,637)$, and with the cow he took two heifer calves of the same family, sired by Proud Messenger (138,641). The Aberdeen October sale of 1919 gave him an excellent opportunity. There he acquired four beautiful heifers of the Augusta, Kinellar Rosebud, Charlotte Corday, and Eliza families. Augusta Belle, a blood-red by Redgorton Expert (144,810), was from Captain Macgillivray's herd; Moss Rosebud 4th, a roan, was from the herd of $\mathrm{Mr} \mathrm{Wm}$. Ingram, Middleton of Troup, and had for sire the fine Lethenty bull, Broadhooks Favourite $(135,441)$, which was exported to New Zealand at a high price; Merry Maid 11th, the Charlotte Corday, was a red of Mr Thomas Kirk's breeding, and by the noted Sanquhar Knight Marshal 
$(133,424)$; and Naemoor Eliza 4th, a dark roan, bred by Mr Moubray, was by Garbity Field Marshal $(142,541)$, one of whose sons sold for $1350 \mathrm{gs}$. at Perth last spring. The Eliza is a granddaughter of Waresley Eliza 2nd, the dam of $\mathrm{Mr}$ Moubray's great bull Star of Dawn $(117,858)$.

Mr Shields' next purchase was in Ireland. From Mr R. W. Bell he bought a very pretty red heifer in Windmill Nonpareil B, by the famous breeder Lord Mayor (132,036). At the same time he took a strong liking to Windmill Standard, a thick-set, short-legged, rich red by Lord Mayor, and from a fine cow of the old Aberdeenshire Beauty family, so notable at Kilblean. The Balcairn 4600-gs. bull calf of last October was of this line of breeding. Turning to his brother's herd at Dolphingstone, $\mathrm{Mr}$ Shields added next a very fine red Princess Royal heifer by a Butterfly son of old Lex of Cluny $(109,170)$. Always on the outlook for a good Clipper, Mr John Gill had bought the grand Cruickshank cattle owned by the late Sir J. H. Maden, and to Stainton Mr Shields went to secure Rockcliffe Ruth Clipper by the Pirriesmill Lord Canning (109,221), which was sold as a calf for 1000 gs. at the sale of the stock owned by the late Mr John Wilson's representatives. The cow is one of the best-bred animals of her family in Britain, as she has the crosses of the finest Newton stock bulls, including Star of Morning $(58,189)$. Her heifer calf is by Mr C. H. Jolliffe's Prince Imperial $(127,411)$. At the North Loirston sale a very finely-bred Broad- 
hooks was selected for the Longniddry herd in the light roan two-year-old heifer Broadhooks 3rd by Red Knight (133,028), and with other three Duthie top-crosses. She was in calf to the 3500 -gs. Collynie Master Lavender $(141,710)$. In June of this year Mr Shields went south again to Stainton and bought from Mr Gill the beautiful young roan cow Collynie Proud Lavender by Lothian Augustus (116,354) out of Sittyton Lavender 17 th by Vanguard $(97,521)$, and with the magnificent backing of Scottish Fancy (75,601), Scottish Archer (59,893), and Gravesend $(46,461)$.

It is evident that $\mathrm{Mr}$ James Shields intends to strike out towards the front rank. He has certainly eased his course by making a strong beginning.

\section{MANDERSTON.}

On the beautiful Berwickshire property of Manderston the late Sir James Percy Miller, Bart., D.S.O., had a very well-bred and capably-managed herd, its quarters being on Buxley Farm, near Duns. $\mathrm{Mr}$ Samuel Thomson, who has been in charge of the lands and stock since 1895, states that there were a few Shorthorns on the farm when he took up his duties, the first purchase having been made in 1892. At the outset female animals were acquired from Mertoun, Wylam-on-Tyne, and Warlaby, and additions were made in later years from Collynie, Uppermill, and Legars. Sir James Miller died on 22nd January 1906, and the herd, with the exception of one heifer 
calf, was sold off on 5th October of the same year. It then contained very good-looking members of the Cherry, Lady Fragrant, Marigold, Grahamslaw, Roan Lady, and what came to be known as the Bella Booth families. The Cherry traced back to a cow of that name sired by Maynard's Son of Petteril (4685). The Lady Fragrant and Marigolds were from Collynie, the Roan Ladys from Uppermill. Bella Booth, bred by Mr James Beattie, Newbie, and by Knight of Knowlmere, traced back to stock held by the Messrs Jobling and Angus. Very fine Cruickshank bulls had been used at Manderston. The Legars Brilliant Chief $(66,741)$ by the Collynie Brilliant $(56,981)$; Prior of Dalmeny $(69,328)$ by Sittyton Seal $(64,866)$; the Legars Scotland's Heir $(75,593)$ by the Collynie Earl Marshal ; the Beaufort prize-winning Orion $(84,265)$ by Victor of Sittyton $(80,171)$, and the Collynie Monarch Fancy $(89,355)$, had bred stock which were greatly admired. The last-named bull, a massive roan over two years old at the time of the sale, was by Scottish Fancy $(75,601)$, out of Monarch's Mysie by Spicy Monarch $(73,701)$, his grandam being by Scottish Archer, and great-grandam by Field Marshal. He left excellent calves.

At the sale twelve cows averaged $£ 58,9$ s. and thirty-two herd $£ 46,13 \mathrm{~s} .2 \mathrm{~d}$. The leading price was 140 gs. for the three-year-old red Scotch Marigold 4th by Royal Edward $(82,153)$. Mr Wm. Duthie took this cow, and her Collynie-bred dam, Scotch Marigold 3rd, by Lovat Champion $(74,948)$, passed to the Duke of Northumberland at 85 gs. Taking breeding and 
individual merit into account, those were cheap cows. Monarch's Fancy was bought by Mr Dunbar-Buller for $67 \mathrm{gs}$.

The existing herd, owned by the Hon. Lady Miller, is entirely composed of Marigolds descended from a beautiful roan heifer calf, Manderston Marigold, by Monarch's Fancy $(89,355)$, out of Scotch Marigold 4th. With the sire first referred to on one side of the new foundation, and with Royal Edward, Lovat Champion, Clarence, and William of Orange on the other side, the fresh departure has resulted in the production of high-class females of a true Cruickshank type. The herd is now composed of five cows, three two-year-old heifers, a couple of yearlings, and a few very fine calves.

\section{Manuel House.}

The Manuel House herd has come into note very rapidly through the successes of the bulls exhibited at the Perth spring shows. Mr James Napier Reynard, the young owner of the herd, a fullyqualified veterinary surgeon with farming and stockbreeding tastes, was comfortably set agoing a few years ago by his father, Mr John Napier Reynard, one of Glasgow's able business men, and also distinguished in bygone years as breeder and exhibitor of dogs and poultry. Mr James N. Reynard made his first Shorthorn selection at the Perth spring show of 1912 in the yearling Miss Ramsden Mermadina, bred by Mr Napier, Nether Dallachy, and by Band 
Sergeant $(101,366)$. On her way south she got her near foreleg broken below the knee, but Mr Reynard's uncle, the well-known Perth veterinary surgeon, attended to her, and in a few weeks she was fit for transference to Manuel, where she has bred four bulls and two heifers. One of the heifers is a red with little white, sired by the Tulliallan stock bull Lancaster Royal $(109,108)$.

In 1914 a light roan Clipper heifer was bought from Mr Napier. That was Golden Clipper by Goldfinder $(11,938)$, from a dam by Watchman $(71,828)$, grandam Coraline by the champion Corner Stone $(68,406)$. Other two purchases were also made at Perth in 1914. The prettily-built red roan yearling Ballechin Duchess, bred by Mr Wm. Rose and by Vinedresser $(101,001)$, and Broadhooks 39th of the late Mr Thos. A. Anderson's breeding and by Royal Prince $(113,183)$, were the selections. The Broadhooks has proved a grand breeder. She is dam of Manuel Censor, the first-prize two-year-old bull at Perth in 1919, and of a handsome heifer by Sittyton Style (110,212). A finely-bred Butterfly heifer was acquired in 1915 from Mr Moore, the Rossshire breeder. That was Butterfly Cup 18th by Minnore Quilter $(109,417)$. Her bull calf of 1919 by Beaufort Rothes General is very promising. Balthayock Waterloo 5th, bred by Mr R. Wylie Hill and by Edgcote Watson $(111,692)$ from a dam by Ivo of Cluny $(99,211)$, was another of the 1915 additions to the herd.

At Perth in $1916 \mathrm{Mr}$ Reynard made an important 
purchase in the first-prize Naemoor Rosewood, a twoyear-old of $\mathrm{Mr}$ J. J. Moubray breeding, and by the famous winner Star of Dawn $(117,858)$, afterwards a front-rank bull in the Argentine. The Rosewood is of much promise as a breeder. At the 1916 Show also Mr Reynard fancied the second-prize heifer Scottish Buttercup 3rd, bred by the late Mr Duncan Stewart, and by the remarkable stock bull Cupbearer of Collynie $(114,960)$. At the Uppermill dispersion sale in $1915 \mathrm{Mr}$ Reynard took out Princess Royal 108th by Nonpareil Clipper, and to Sittyton Style she bred in 1917 a highly promising heifer calf. One heifer and four heifer calves were bought at the Aberdeen October sale of 1916. These were Boquhan Broadhooks Beauty, bred by Mr Stephen Mitchell, and by Collynie King Royal (114,768); three Redgorton-bred calves by Edgcote Czar (120,081) - Fairy Queen 38th, Crocus Lass, a granddaughter of the champion Cluny Crocus, and Crocus Beauty, a great-granddaughter of the champion,- - the three being from cows by Pride of Livet $(109,678)$ and Violet Bloom, a very fine Sittyton Violet calf bred by Mr J. Ernest Kerr and by Cranham Gerome (119,680). At Mr George Harrison's sale Mr Reynard bought three heifer calves - a couple of Nonpareils and a Lady Dorothy. A first-class Augusta heifer calf was acquired at the Aberdeen autumn sale of 1917, this being Augusta 116th, bred by Mr H. M'Lennan Duncan, and by the excellent sire Boquhan Pride $(111,114)$. At the Aberdeen October sales of $1919 \mathrm{Mr}$ Reynard acquired three beautiful heifer calves. These were the dark 
roan Lavender 71st, 1000 gs., bred by Mr David Anderson, North Loirston, and by Collynie Master Lavender; Newton Blythesome, 360 gs., bred by the late Colonel A. T. Gordon, and by Collynie Lavender King; and the Orange Blossom Cherry Blossom 12th, 320 gs., bred by Mr J. Knox Ledingham, and by Mr Duthie Webster's Royal Defender (vol. 65). A couple of beautiful yearling heifers were recently added to the herd from Bapton Manor. These are a red Venus or Dairymaid by Boquhan Stamp (114,408), and a roan Crocus by Bapton Malcolm (134,909).

The principal bulls used have been the Collynie Sittyton Style (111,272); Redgorton Censor 2nd (127,611) - winning two-year-old at Perth in 1916; Redgorton Epicure $(133,013)$, the third-prize twoyear-old of 1917 ; Ballechin Cardinal (134,795), bred by Mr Rose and by Cupbearer of Collynie; and Collynie Bright Hope, a red now in use, sire Lothian Augustus (116,354), dam Bessie 61st by Royal Leader $(103,727)$. Ballechin Cardinal was sire of Mr Reynard's first-prize two-year-old bull at Perth this year - the handsomely proportioned massive roan, Regent, which was sold for 2500 gs. He was out of Naemoor Rosewood by Star of Dawn $(117,858)$.

Manuel House and farm are in Stirlingshire, with the little river Avon as boundary between the home range and Linlithgow. Mr Reynard now farms in the two counties, as he recently bought the desirable holding of Woodcockdale just across the water and running to 157 acres. The extent now owned is 454 acres, of which 320 acres are arable. Pleasantly 
situated with gentle heights and howes and breaks of woodland, it is an attractive spot with very useful loamy soil in every field, mainly over limestone. The Shorthorn homestead is by the river-side, where a meal-mill hummed merrily in other days. Quarters for the cattle are up to the times in comfort and circulation of fresh air.

\section{Masterton.}

This extensive holding on the Pitreavie estate, near Dunfermline, has come into fame through Border Leicester sheep. The father of Mr James Butters, the present tenant, took up farming at Masterton almost fifty years ago. The holding has an extent of about 500 acres. On the lower reaches clay and strong clay loam prevail, but as the land rises to fairly steep slopes over sandstone, the soil becomes easier, and on the upper reaches it is a miscellaneous blend of scourings from various quarters. Mr Butters is also tenant of the adjoining farm of Middlebank, which runs to 300 acres. Falling in with the Shorthorn cause in 1919, he has shown a good combination of caution and enterprise, and as he possesses a correct eye and a large amount of general experience, he ought to pass expeditiously through the recruit stages. Meanwhile farm buildings are being gradually remodelled for the new departure.

At the Perth spring sales of last season Mr Butters selected a couple of Broadhooks heifers, a Matilda, a Rosemary, and a Constance. Broadhooks Bet, a 
shapely roan by Spicy Beau $(139,497)$, was from the herd of Mr George Douglas, Rhynie; White Duchess Cassandra, the other female of the same line of breeding and a red in colour, came from the noted herd owned by Mr Gordon Oswald of Aigas, whose Broadhooks have a prominent position in the Shorthorn world. The Aigas heifer was by Ambassador $(134,614)$. Madge 11th, a red of the old Aberdeenshire Matildas, was from Dalcapon. Sired by Notlaw Nelson $(127,166)$, and in calf to Brawith Chieftain $(141,177)$, she produced a very good red bull. Rosemary 98th, a red by Mastodon $(102,989)$, and with a red heifer calf at foot by Collynie Boy $(130,285)$, and Constance, a red by Collynie Boy with roan heifer calf at foot by Ardlethen Colleague (vol. 64), were from the herd owned by Messrs Forbes, Muirton of Barra, Aberdeenshire. Attending the Aberdeen October sales, Mr Butters paid 400 gs. for the beautiful heifer Doune Meg Merrilies 6th, a red by Dunglass Brilliant $(120,003)$. She was in calf to the Earl of Moray's fine stock bull Eclipse of Collynie (136,344). From Mr George R. Grant's lot he took a pretty red calf, Auchnacree Moth 28th, a Champion of England Butterfly by Auchnacree Rajah $(134,744)$, and Lady Ramsden 11th, a handsome roan bred by $\mathrm{Mr}$ Wylie Hill, and by Franciscan (vol. 64). At Colonel Johnston's sale Mr Butters secured at 380 gs. a fine Brawith Bud heifer in Linksfield Vinolia. She was in calf to the 3000-gs. bull Lothian Mario (137,713). Then at the Newton dispersion sale he took out at 340 gs. 
Lustre 9 th, a red heifer by Towie Barclay Landsman $(139,769)$. That heifer was bred by Mr William Cran, Gerrie.

Mr Butters has made an excellent start. His stock bull is Kinellar Proud Duke, an admirably top-crossed roan member of the Matilda family by Collynie Proud Duke $(135,827)$, and with Collynie Storm Prince (111,339), Lavender Vanguard (105,941), and Ballechin Type $(85,212)$, next in order.

\section{MiLlhills.}

What memories pass under the review of countless numbers in all lands at the mere mentioning of the one word "Millhills"! A quarter of a century ago the place was unknown beyond its own parish. It now suggests abounding enthusiasm in the Shorthorn cause, a remarkable series of showyard and sale-ring successes, inspiration in the work of breed-improvement, and large-hearted practical helpfulness. $\mathrm{Mr}$ Duncan Stewart, who died at Lawers on 17 th February 1919 , at the age of sixty-eight, had to be contented with a small herd for a few years. When he began to acquire foundation animals in 1897 he had under 50 acres of land at Millhills. By degrees, however, he gave his favourite breed more and more range through additional purchases of farm lands. At the end of his days he had from 70 to 80 head of Shorthorns, and that total may be exceeded ere long by the new proprietor, $\mathrm{Mr}$ Duncan Stewart, as there is an extent of about 120 acres in connection with the 
home farm, fully 236 acres at lower-lying Dalpatrick, and in addition, 100 acres rented from the Innerpeffray estates. The pure-bred herd has thus ample bounds. At Dalpatrick some very fine commercial animals have been bred and fed, but latterly the farm has been more used as grazing ground and wintering quarters for the younger portion of the increasing pure-bred stock. On the upper section of land at Millhills, a sharp loam over a gravelly subsoil prevails for the most part, and some of it tends to scorch in course of a dry summer; but towards the valley at Dalpatrick the soil is deeper and of more substance. High-farming has put the whole of the lands into first-class cropping and grazing order, and the produce is of excellent feeding quality. The pretty steading at Millhills was of course originally intended for a smaller herd than the one now in possession, but in recent years there have been some ingenious rearrangements, with the result that every justice is done to stock in comfort and fresh air. Dalpatrick has one of the best steadings in the country.

Mr Stewart's first Shorthorn was a Carnation, bred by the late $\mathrm{Mr}$ Alexander Robertson, Ballechin. A little later, in September 1897, he attended the Dalmeny sale and bought the Collynie-bred Veronica 2nd of the Violette family. Then came a Julia or Dairymaid from Beaufort Castle, and Lady 22nd from Balnakyle. The Dairymaid, a beautiful red heifer by Royal Star, was very successfully shown, and she proved a fine breeder. Lady 22nd, a hand- 
some roan, also won a number of prizes, but none of her line is now in the herd. Mr Stewart's next purchase of consequence was Lady Bountiful, a good roan heifer of the Waterloo family, from the late $\mathrm{Mr}$ George Inglis of Newmore. Sired by Master Archer $(73,007)$, this heifer developed into a very good-looking cow, and she bred remarkably well. A bull-calf out of her took second at Perth, and sold there at what was then considered the great price of 500 gs. Another of her bulls went at 350 gs. From Pitcur a fine representative of the Matadore family was acquired, and of succeeding purchases the most important were a Missie from Mr W. S. Marr, Uppermill ; a Nonpareil, a Pauline, a Rosewood, and a Clipper from Newton; a Princess Royal and a Secret from Collynie; a Clipper from Aldbro; a Clipper and an Augusta from Heatherwick; a Queen of Rothes from Beaufort Castle; a Marigold and a Rosebud from Duchlage; a Grace from Sanquhar, and a Goldie from Damside. Clipper Princess by Aldbro Scottish Prince $(97,805)$ is dam of Clipper Star $(124,786)$, for which Mr Wm. Duthie paid 1050 gs. at the Perth spring sale of 1915, and Clipper Star was sire of the very pretty Secret heifer calf for which Mr Stewart paid 300 gs. at the Collynie sale of 1916.

In selecting stock bulls Mr Stewart's question always was, "Which is the best in individual merit and breeding?" Having satisfied himself that certain animals were the fittest for his purpose, the matter of price never came into consideration. "If your females are improving by breeding and careful 
selection," he said at one time, "be all the more difficult to please in your choice of stock bulls." The first bull to make a strong impression at Millhills and in the district was the Uppermill-bred roan Golden Gift $(81,168)$ by Spicy Robin $(69,638)$, out of Goldie 39th by Captain of the Guard $(58,596)$. After being used two seasons Mr Stewart passed this grandly bred bull on to Crieffvechter, where he left a uniformly high-class lot of heifers, which in their turn proved valuable breeders. Proud Favourite $(84,420)$, the next of the important bulls selected for Millhills, was a handsome red Uppermill-bred Princess Royal by Bapton Favourite $(76,080)$, from a very fine William of Orange cow. He lacked something in the fore-ribs, but he was very mellow-fleshed and had good hind-quarters. As a yearling he won at the Highland. The Roan Lady bull Royal Eclipse $(87,179)$, also of Marr breeding and by Bapton Favourite, suited the Golden Gift and Proud Favourite females very well, although his type was not quite the same. He was a lightish roan, beautifully smooth, if not specially deep in flesh. His frame lacked width to some extent, and he went against the Wanderer and William of Orange crosses in his blood by being rather upstanding to begin with, but he improved with age. He led at the Highland as a yearling, and as an aged bull he took first at the Royal Dublin Show and stood reserve for the Chaloner Plate. His constitution must have been of the very best, as he never looked in finer form than when exported by Mr A. J. Marshall as a six-year-old. The Collynie-bred red 
roan Clara bull Captain of the Mint $(94,565)$ by Collynie Mint $(88,221)$, had the Captain of the Guard and William of Orange crosses through his dam. He had great fore-quarters and a wealth of natural flesh, but he lacked finish in the rear. Still he promised to be a remarkably good breeder, and he had too short a reign. His son, President of the Mint $(109,670)$, which has been owned for several years by Lady Cathcart, is one of the best breeding bulls of the day. Scottish Farmer $(103,837)$, a very good-looking red by Achilles $(93,962)$, out of Collynie Fancy by Scottish Fancy $(75,601)$, was not extensively used in the herd; but his successor, the roan Collynie Cruickshank $(105,068)$, was in use for six seasons at Millhills, and he is now in his fourth season at Duchlage. This fine old Clipper bull is by Golden Primrose $(98,979)$ out of a beautiful cow by Pride of Avon, and two removes further back he has the Star of Morning cross. As a yearling Collynie Cruickshank took first and reserve championship at the Highland. His greatest success has been as a breeder of females. It is sometimes very difficult to make comparisons between bulls on breeding lines, because no two sets of conditions are alike; but granting that the way was remarkably well prepared for the now eight-year-old red roan bull Cupbearer of Collynie $(114,960)$, most judges would be inclined to say that this medium-sized Queen of Rothes son of Merry Stamp $(99,629)$ and half-brother to Knight of Collynie, has had no equal at Millhills as a sire of males and females. The more massive but higherstanding red Collynie Bright Star $(130,287)$, by 


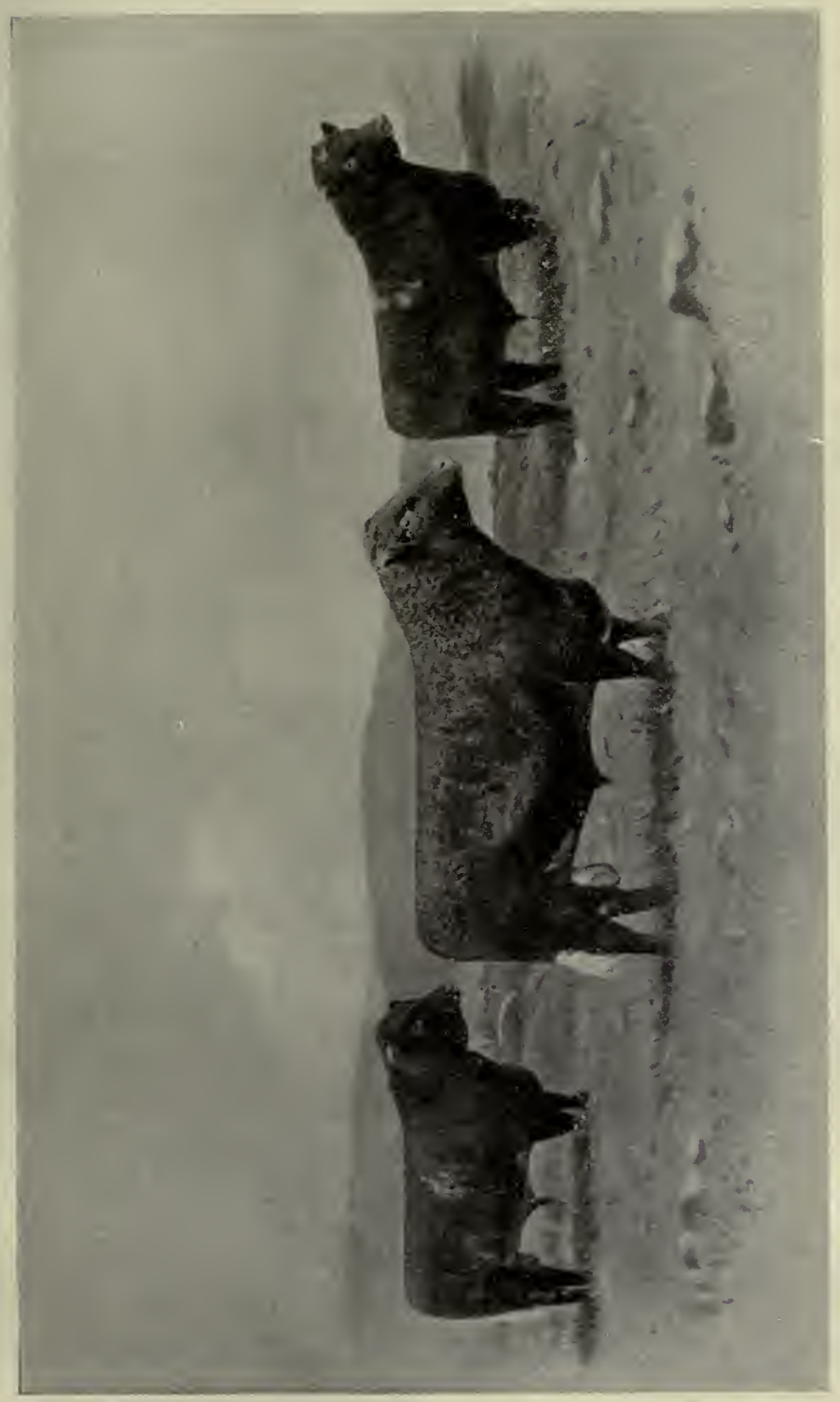

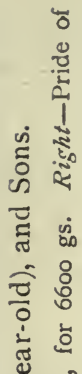

¿

¿

ज ले

(1) 는

ช 05

8 ํํำ

告四弯

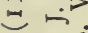

(1)

군

걱응

ㅇํ용

(ㄷ.

जี

․ㅡㄹ

ณ ह ह

品 है

宁 $3 \frac{5}{0}$

ง जั.

穴

ก ก

บ돈

क के

छั

至

交 

Knight of Collynie (112,229), the half-brother of Cupbearer, and the 2700 gs. dark roan Collynie Lavender King $(141,709)$, by Max of Cluny $(112,487)$, from a Knight of Collynie cow, have great opportunities in Mr Stewart's herd.

The Millhills herd's long list of prizes cannot be noted in detail. Reference can only be made to a few of the principal honours. In 1912 Scottish Grace, bred in the herd and exhibited by the Earl of Rosebery, won the female championship at Smithfield and the reserve for the championship of the show. Four years later Roan Grace took the Scottish National championship. The Perth Show of young bulls provides one of the severest tests in the world, and the winning of the group prize is rightly regarded as a high-class distinction. Mr Stewart won the group prize in $1905,1914,1916,1918$, and his representatives won in 1920. In 1905 he was second in both classes; in 1914 he won the firsts; in 1916 he took second in juniors; in 1918 he carried off first and second in the April class with Marigold and Queen of Rothes, sons of Cupbearer. Pride of Millhills, the class winner, a blocky roan of wonderful development for his age, further won the Maclennan Cup as best bull in the show, and was sold to $\mathrm{Mr}$ F. B. Wilkinson for export to the Argentine at $3100 \mathrm{gs}$. In 1920 the very massive red roan Clipper bull, Millhills Comet, by Cupbearer, took the championship, and in the sale ring he made the record price of 6600 gs., his buyer being $\mathrm{Mr}$ Elliot, Guelph, Ontario. 
It would be difficult to estimate Mr Stewart's work as an improver of Shorthorns in his native county. To breeders and patrons of the cosmopolitan cattle everywhere his wonderful personality with its scope in outlook impelled men to action, and if there were blocks in the way he did his utmost to remove them. Throughout the main portion of his course as breeder, exhibitor, and stimulator, he had thorough backing from one who was in certain respects a Scottish counterpart to Joe Culshaw. The former herdsman, latterly the farm manager at Millhills, was a masterly trainer of an animal.

\section{Mrlton of LuncaRty.}

Mr Scott Wyllie, Milton of Luncarty, on Mr Maxtone Graham's property, is better known as a breeder and judge of Clydesdale horses than as a devotee of Shorthorns. In 1912 he began to form a herd, and since that time he has bred and sold a good many female animals of the most fashionable blood. He began with Marigold Ruby 2nd, bred by Mr Sylvester Campbell, Kinellar, and from the same breeder he afterwards acquired an Orange Blossom. Then he added a Rosebud by Primrose Star (106,555) from the Right Hon. A. J. Balfour; a Broadhooks from Mr Douglas, Rhynie; a Butterfly and a Lady Dorothy from Lord Clinton; a Brawith Bud by Royal Leader $(103,727)$ from the late Mr John Watson, Kirkwood House, Strathaven; a Queen of Rothes from Messrs Robertson, Cloichfoldich; an Augusta 
from Major Maclean of Drynie; and a Rothiebrisbane Myrtle from Mr Fraser, New Aberdour. The bull now in use is the handsome roan Harviestoun Royal Duke of the Airdrie Duchess line of breeding, and by the Saphock Royal Clarion $(139,028)$.

Mains of Luncarty is a well-sheltered river-side holding of over 160 acres. In a more or less showery season stock do very well on it, a great advantage being the access to running water. As the land is all on a gravelly subsoil, a dry season shrivels up the pastures. Still it is a healthy spot, and the tenant makes the most of it.

\section{Moness.}

One of the delights of Colonel Charles Munro was to take stock-breeding enthusiasts a short distance uphill to his charming show-farm of Moness at the edge of the "Birks," just outside the burgh of Aberfeldy. In winter, or at any time when the burn was in spate, the noise of many waters could be heard as one approached the bridge near the Falls; and on the way to the steading the ear could take up hints of the gloriously hilarious tumult. And there was the Colonel in the mood for the hour: brisk, natty in attire, with something of the parade-ground in the poise of the head and set of the shoulders; nimbly switching from lightly grave to brightly gay, and hospitable as a glowing fire after a sleety upland October shooting.

When the Colonel retired from farming in 1914, 
his two sons, Mr William Munro and Mr Charles J. D. Munro-the latter afterwards well known as a captain in a Highland regiment during the wartook up the tenancy of Moness and lost no time in founding a select herd of Shorthorns. They started with the great advantage of being thorough judges of the breed and adepts in the ramifications of pedigree. In the autumn of 1914 the dark roan twoyear-old heifer, Proud Golden Drop 2nd, was acquired from Mr Stephen Mitchell. Her sire was the Saphockbred Proud Champion (109,765). Her first calf was the white heifer Proud Golden Drop 5th by Keir Quartermaster $(120,896)$. She followed with the red bull Goldsmith by Primrose Prince $(127,380)$; the dark roan bull Golden Star, a Perth fourth-prize winner in 1919, sire Collynie Violet Star $(135,830)$; and the red heifer Proud Golden Drop 6th by Collynie Royal Duke (141,715). Goldsmith was sold to $\mathrm{Mr}$ James Sidey for exportation. For Golden Star Mr Joseph Shepherd paid 620 gs. Both heifers from this excellent Golden Drop cow have been retained in the herd.

A very fine Lavender and one of the best of Blythesomes were also secured by the Messrs Munro in 1914. Lavender 66th, a red heifer calf from the herd of Mr David Anderson, North Loirston, Aberdeen, was a highly fortunate selection, as she bred three grand heifer calves in succession - the dark roan Perth 2nd prize, Lavender 70th by Collynie Clarionet $(124,840)$, sold to $\mathrm{Mr}$ H. B. Marshall of Rachan for 340 gs.; the red Lavender 71st by 
Primrose Prince $(127,380)$, sold to Mr J. D. Fletcher for $510 \mathrm{gs.}$; and the dark roan Lavender $72 \mathrm{nd}$ by Collynie Violet Star $(135,830)$, and one of the gems of her year, for which Mr W. M. Cazalet paid 820 gs. In 1919 the Lavender cow produced a beautiful roan bull calf, Lavender Regent, by Collynie Royal Duke (141,715). Blythesome 26th, a dark roan, bred in Ireland and by the Pirriesmill Proud Emperor $(112,912)$, has done remarkably well as a breeder. To Clipper Favourite $(124,782)$ she calved in 1915 Blythesome 29th, a handsome red, bought by the late Colonel A. T. Gordon of Newton, who sold her to $\mathrm{Mr}$ C. H. Jolliffe. The latter disposed of her again for 650 gs. The good red bull, Baron's Pride, followed and passed to South America, and the cow bred another red bull in 1919 to Collynie Royal Duke.

Properly top-crossed representatives of the Sittyton Crocus family are in very few hands. In the summer of 1915 the Moness herd had an important addition in the dark-red roan yearling heifer Caroline, bought privately from Mr J. Deane Willis. She was a heifer with a beautiful head and a wonderfully perfect top. Her first calf was the red roan Cardinal by Primrose Prince $(127,830)$. This bull was sold to Major Murray of Polmaise, and subsequently exported. A red roan heifer named Constance by Collynie Violet Star came next, and was retained in the herd. In 1919 Caroline bred a white bull calf by Collynie Royal Duke.

In the autumn of 1915 a very fine rich roan, Orange Blossom, heifer calf by the Collynie Lavender Favourite $(121,106)$, was bought from Colonel Gordon. Two of 
her daughters, a white and a dark roan, were sold at 300 gs. each to Mr Donald M'Dougall, Dall, Killin, and Mr Jolliffe. Lavender 69th by the Cromleybank Admiral $(123,793)$ was secured at the same time from Mr George Walker, Tillygreig. She has done remarkably well. Lavender Star, her red bull calf of 1918, was sold to Mr Bowden, Dublin, for 410 gs. Three families of the Sittyton Butterfly foundation were acquired at the late Mr George Murison's sale, near Stonehaven, in 1916, and one of these, Butterfly Rose by Beaufort Count $(114,249)$, is now in the herd. She is a fine breeder. Butterfly Star, her dark roan bull calf of 1918 , was third in a class of 150 at Perth in 1919, and was sold for 420 gs. From Mr Wylie Hill in 1916 there was bought the massive roan cow Victoria 71st by Scottish Regent $(93,373)$, and at Moness she bred three heifer calves. One of these, Victoria 73rd, a red by Collynie Violet Star, was sold in 1919 to $\mathrm{Mr}$ William M'Allister for $£ 1000$.

The Messrs Munro's latest selection is what is believed to be the only straight-bred Alexandrina in this country. She was bred by the late Lord Calthorpe, and is by the noted Collynie bull Lavender Royal $(86,380)$; her dam being Alexandrina 30 th, the second highest priced female animal at the Uppermill dispersal sale of 1905 .

The high-class bulls used by the Messrs Munro have been referred to in passing. Collynie Royal Duke (141,715), the sire of the present crops of young bulls and heifers, is a massive, level-fleshed, beauti- 
fully-balanced roan by the red Collynie Bright Star $(130,287)$, so successfully used at Millhills, and is out of a first-class Duchess of Gloster heifer by Max of Cluny $(112,487)$, grandam by Bapton Champion, great-grandam by Wanderer $(60,138)$.

No prettier little herd than the Moness one can be seen in Scotland. The farm, which is composed of kindly soil, grows and feeds stock very well. Upper fields are open to the east winds, but there are cosy bits low down and at the burn-side. Farm buildings have been considerably improved in recent years.

\section{NAEMOOR.}

"It's no aye rainin' on the misty Aechils, It's no aye white wi' winter on Nigour ; The winds are no sae mony sorrowin' Rachels That grieve an' o' their grief will not gie ower."

-By the author of 'Horace in Homespun.'

The finest monument to Mr John Moubray of The Moor and Cambus, grandfather of Mr John J. Moubray, is the Naemoor section of the Devon valley. That part of the country gained much climatically before the middle of last century through the improver's enterprise, and since that time the conditions of life on and near the old "Moor of Muckart" have been made gentler by continuous attentions to drainage and tree-planting. With the Ochils on the north and the Cleish Hills well in the distance to the south, Naemoor falls easily towards the sun. At the farm buildings the elevation is over 500 feet. Most of the 
soil is of that fluffy nature which hints at a history of bog, peat, and waste, but high-farming has done much to improve the land in stock-carrying. One saving grace is that the animals have ample bounds. For another matter, the plough is set to work when fields threaten to revert to bent and other poor grasses. The farm buildings are now excellent for a breeding herd, as comfort, thorough ventilation, light, and feeding convenience have received the most skilled attention.

With Shorthorn associations in ancestral lines and family connections, it was but natural that $\mathrm{Mr}$ John J. Moubray of Naemoor, Glendamph, and Killerby should fall in as a supporter of the red-white-androan cause. His opportunity came in 1885 at the Blebo sale, where he acquired three female descendants of Mr Ainslie's famous Highland Society winner Romping Girl (page 41). In Mr Bethune's herd these were termed Strawberries, and as Blithes they formed the most numerous family at Naemoor. To the Blithes Mr Moubray added representatives of the Killerby Georgie and Calomel families from Mr Hugh Aylmer's herd. He also bought some excellent cows and heifers from the late Mr Thos. Christopher Booth of Warlaby. In the early stages of the herd's history bulls were acquired from the Messrs Mitchell, Alloa. From Mertoun a famous bull came in Royal Herald $(64,736)$, a very handsome roan of large scale, which was bought back by Lord Polwarth and exhibited as a five-year-old at the Leicester Royal of 1896, where he won the championship. That member of the Man- 


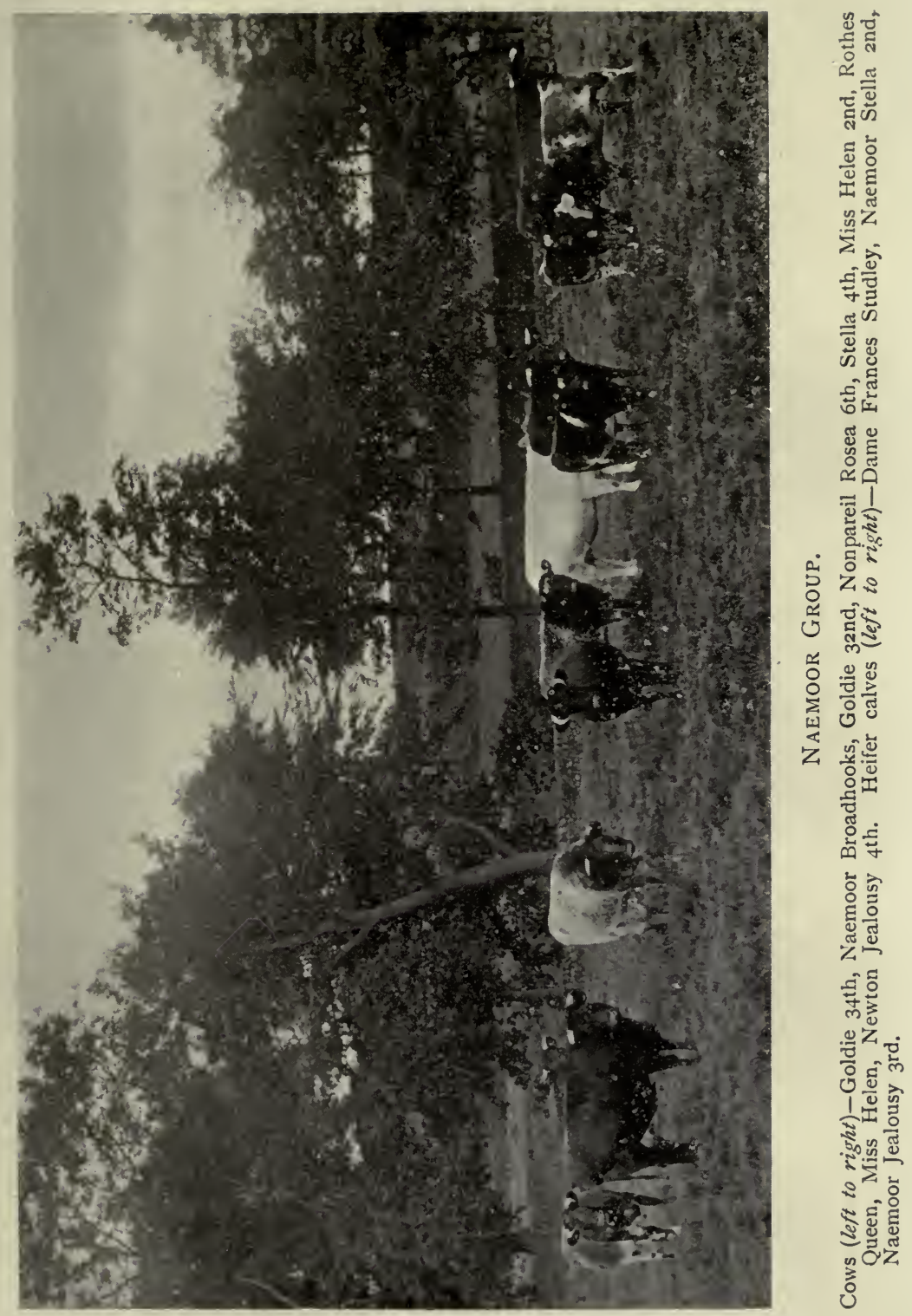



talini family was followed at Naemoor by Fitz Riby $(70,447)$, from Alnwick, and Sir Grimston Studley 2nd $(75,668)$, and Sir Charles Grimston from Sir Jacob Wilson's herd at Chillingham. Lord Mayo $(77,090)$, bred by Mr Richard Booth, was in service when the herd was dispersed in October 1901. The cows were thoroughly Booth in character, with large frames, strong backs, wide ribs, and long quarters, while colours ran mainly to good roans. Times were dull, however, and prices took a moderate range, the average for 40 head being $£ 25$.

Only a few Shorthorns were kept at Naemoor for a number of years after the dispersion of the Booth herd. Prior to 1909 one or two females of Scotch blood were introduced. An Uppermill Bessie by Star of Morning was the most typical in the experimental purchases, but a Garne Rosamund from Collynie with Cruickshank top-crosses looked very hopeful. With the exception of a very fine Bright cow and her daughter, the Naemoor herd is now a distinctively Cruickshank one. It was mainly with the object of striking out on fashionable Scotch lines that $\mathrm{Mr}$ Moubray engaged as agent the enthusiastic $\mathrm{Mr} \mathrm{Wm}$. F. M'Laren. To all intents the existing herd at Naemoor was founded in 1909. At the Ballechin dispersion sale in October of that year the grand cow Ballechin Roan Rose, of the Rosebud family, and by Victor Chief $(82,532)$, was bought for 270 gs. In $\mathrm{Mr}$ Robertson's possession she produced the noted show and breeding bull Jim Sidey $(99,230)$, the grandsire of $\mathrm{Mr} \mathrm{Wm}$. Duthie's great bull Max of Cluny. 
Roan Rose when bought was in calf to Tom Bowling $(97,441)$, and at Naemoor she bred the roan bull calf Question Mark (109,803), which Mr Moubray used very effectively for two seasons. He became the sire of some grand females, among others the white Bright cow Dame Alice Studley, and an Eliza of great substance and distinguished appearance. A valuable addition was made to the herd in 1911 when Waresley Eliza 2nd by Waresley Crystal Star $(101,039)$ was secured at Lord Calthorpe's sale for the moderate figure of $110 \mathrm{gs}$. In calf to Proud Victor $(103,447)$, she bred at Naemoor the noted Star of Dawn $(117,858)$, which won in the senior class at Perth of 1913 , and brought the then remarkable price of $1000 \mathrm{gs}$. In the Argentine Star of Dawn was sold for $£ 3750$. Descendants of Waresley Eliza 2nd now form a strong company in the female line at Naemoor, and her son, which was put to a number of heifers before being exported by the late Mr Donald Maclennan, proved a first-class breeder.

At the fall of $1911 \mathrm{Mr}$ Moubray bought from $\mathrm{Mr}$ Duthie the roan heifer calf Collynie Rosaline, a Roan Lady by Moonlight Yet $(103,125)$. By a curious mishap she produced a bull calf before she was quite eighteen months old. Still, she grew into a fine big cow, and bred some good animals, among others the Perth firstprize bull of 1918, which was sold for the States at 700 gs. He never reached the far side of the Atlantic, as he fell a victim to a German submarine torpedo. During the last eight years the Estelles have done remark- 
ably well in Mr Moubray's herd. At the Pirriesmill dispersion sale Stella 2nd, by Earl of Elgin $(91,589)$, and her heifer calf Stella 4th by Golden Hero $(91,857)$, were bought for 150 gs. and 90 gs. respectively. At the same sale Mr Duthie bought a full sister to Stella 2nd, and at Collynie that cow has been the dam of the Millhills stock bull Collynie Bright Star $(130,287)$, and grandam of the Doune Lodge Eclipse of Collynie (136,344). Stella 2nd has proved a wonderful success through her daughters. Her granddaughter, Naemoor Stella, was exported to the States, and at Messrs Carpenter \& Ross's sale she was sold for $£ 970$. An Edgcote Masterpiece, grandson of the old cow through another daughter, was very greatly admired at the Perth Show and sale of 1919. He was then going very lame, but Messrs Carpenter \& Ross paid $1000 \mathrm{gs}$. for him, and on the other side he passed out of the ring at $£ 3200$. On him the 'Breeders' Gazette' commented: "His head is ideal; he is specially level in his lines, mellow as could be desired, and is a real bull from every point of view. He fills the eye as have few seen by the writer in years."

The late $\mathrm{Mr}$ A. M. Gordon of Newton bred some noble-looking cattle of the Jealousy family. At his dispersion sale Mr Moubray took out a fine cow in the six-year-old Newton Jealousy 4th, her price being 220 gs. Mated with the great stock bull Edgcote Masterpiece, she bred the Perth Spring Show champion of 1916, Velox of Naemoor, a magnificent specimen of a Shorthorn in character, substance, and balance, but handicapped by a splashy form of roan. 
Still he sold for $1550 \mathrm{gs}$, and in the Argentine he drew about $£ 2750$ at public auction. Daughters of the old cow by Edgcote Masterpiece are of very good colour. Newton Molly 3rd, acquired at the same time as the Jealousy, bred a notable bull in Viking of Naemoor. Heatherwick Mayflowers have done quite well. Warrior of Naemoor was a first-prize winner at Perth in 1917, and was afterwards used with marked success at Dalmeny. Mr Moubray's herd is strong in Clippers. The first of the line was bought from $\mathrm{Mr}$ John Hill in 1913. That was Clipper Pride by Ascott Pride $(104,567)$, and with the Star of Morning cross in her pedigree. A singularly beautiful roan granddaughter of this cow was sold at Birmingham in 1918 to the Messrs Jones of Dunmore Park for 650 gs. At the Mains of Sanquhar draft sale of $1917 \mathrm{Mr}$ Moubray took out a fine Clipper of the Zoe branch at 610 gs., and next season she produced a red heifer calf by the blocky Newton Count, and she followed with a beautiful roan heifer calf by Edgcote Masterpiece.

Goldies have the very finest of foundations at Naemoor in the show cow Goldie 32nd, acquired at the Whittingehame dispersion for 370 gs., and Goldie 34 th, a very pretty roan calf out of the same dam as Goldie 32nd. A highly successful breeder was selected at the same time in Harviestoun Butterfly by Mr Duthie's noted stock bull Jubilant $(99,240)$. The first of the Broadhooks came from Mr George Argo, Petty, Fyvie, in 1911, and the greatest cow of the line now at Naemoor is a red by Star of Dawn. For a time the Augustas and Rosewoods were tried, but 
they were soon cleared out. The like fate befell the Lady Dorothys. They did not come up to expectation, and their pedigrees did not save them. Recent additions to the herd have been a Queen of Rothes from Cloichfoldich; a Lavender from Newton of Barra, Aberdeenshire; a Princess Royal from Mr A. J. Marshall, and a Clara from Major Graham Stirling. The first named, which is by Keir Quartermaster $(120,896)$, was second-prize yearling at Perth. The Lavender was one of the prettiest calves at Aberdeen in 1917. A better bred Princess Royal than the one from Mr Marshall's herd could not be found. She cost 800 gs. The Clara is a true Uppermill one with the William of Orange cross.

In stock bulls pride of place at Naemoor must be given to the white Edgcote Masterpiece $(115,277)$ by Bletchley King $(98,112)$, out of Lady Mabel by Pride of Avon (86,878), grandam by Bacchus of Dalmeny $(66,642)$. As a yearling in 1913 he won first at the Royal, the Highland, and the Oxfordshire, and was champion at the Huntingdon Show. $\mathrm{He}$ was not shown again, as he was by far too valuable for breeding purposes. In every sense of the word Masterpiece is a great bull. His head is a model: it combines so perfectly masculine impressiveness, Shorthorn character, and placid dignity. And the framework is in keeping. It is wonderfully massive on short legs, and a thick smooth cover of lean flesh is never awanting. As a sire the old bull has proved invaluable. Among other bulls used by Mr Moubray in recent years have been the Boquhan-bred red Cupbearer $(111,475)$ of the Claret 
family, and Beaufort Rothes Prince $(124,215)$, a dark roan member of the Queen of Rothes family by Nestor of Cluny $(116,733)$.

With such a grand collection of females by Edgcote Masterpiece, the difficulty is to strike a perfectly successful dark-coloured cross. The chances are entirely in favour of $\mathrm{Mr}$ Moubray. Merit and highclass breeding are combined in his latest purchase, the red Broadhooks bull Balcairn Crusader, which cost 2300 gs. at Mr Wallace's sale. The young bull is by the great sire Earl of Kingston $(120,041)$, and his dam is by the Uppermill Royal Luxury (106,919). Calves of exceptional promise are now being left by the red Garbity Field Marshal (142,541).

\section{Nether Kinnedder.}

Sixteen years ago the brilliant surgeon, Dr (now Sir Kennedy) Dalziel, bought the South Fifeshire property of Nether Kinnedder, extending to about 1200 acres. Early life experience in his native Dumfriesshire turned Sir Kennedy to landed affairs, and very specially to the breeding and general management of hill sheep; and from those bases it was but natural that he should build and vary as time and opportunity should determine. South-west of the Saline Hills, and with a general fall towards the south and south-west, Nether Kinnedder is of course over the coal measures. It is in five farmsKinnedder Mains, Blairsgreen, Standalane, Cattlemoss, and Bickramside. Most of the soil is a useful 
loam over bluish clay, part is on gravel, and small sections are of a mossy nature. From 300 to 400 acres of the property are in young woodlands, mostly larches, Scots firs, and spruces, and the substantial old mansion-house is set in stately policies where great oaks, ashes, elms, and beeches give no hints of submission to time. The soil in that part is deeper and evidently richer than the average. In the early part of last century Lord Kinnedder, a representative of the Erskine family, had a quiet retreat here from the Court of Session, and here also Sir Walter Scott had periods of musing and writing. $\mathrm{He}$ was then emerging strongly from what Carlyle might have been tempted to term a "Centre of Indifference" between Law and Minstrelsy, and was in the first flush of Romance.

On Blairsgreen, which has an extent of 150 acres, Sir Kennedy began to form a Shorthorn herd in 1918. $\mathrm{He}$ has now representatives of the Zoe Clipper, Kilblean Beauty, Undine, Rachel, Kirklevington, and Graceful families. The Clipper is a red four-year of big scale, bred by Mrs Burnyeat, and by the late Colonel A. T. Gordon's Nonpareil Champion $(112,667)$, out of a dam by Golden Treasure $(95,346)$. Being of the Zoe line of descent she has the much-prized Star of Morning $(58,189)$ cross. At foot she has an exceptionally promising red bull calf by Moresby Pilot (vol. 65). Lothian Betty 4th, the member of the Kilblean Beauty strain of breeding, is a pretty roan yearling, bred at Dalmeny and by the noted Collynie Grand Duke $(124,844)$, while her mother was by the 
remarkable stock bull Millicent Chief $(96,096)$. Thirty years ago some of the most beautiful female animals in the Beaufort Castle herd were of the Undine family. Undine 38 th, a white two-year-old, bred by Mr C. M. Bruce at The Langcot, and by Collynie Regal Lavender (114,770), has much of the old character and style, and her heifer calf, a roan by Collynie Proud Beau, a 600-gs. purchase by Mr Bruce at Mr Duthie's sale of 1918 , shows real distinction. The Rachel, a red two-year-old, bred by Mr Buchanan at Whitehouse, is one of the best-bred heifers of her line. She is fifth in descent from the massive Uppermill William of Orange $(50,694)$ cow Rapture, owned for some years by the late Mr Donald Fisher; her grandmother was Rachel of Ballechin, a high-class cow by Marquis $(84,061)$, one of the most perfectlyshaped bulls of his time, and she herself is by the handsome show bull Auchnacree Laird (134,740). Female animals of old Bates families and with topcrosses of Cruickshank blood might be more generally favoured. In Keepsake, a red two-year-old of Kirklevington descent, bred by Mr A. Wybergh in Cumberland, the young herd at Nether Kinnedder has an animal of scale and much sweetness. She is by $\mathrm{Mr}$ John Gill's Prince Butterfly $(132,797)$, and her dam, which was bred at Auchnacree, was by the wonderfully successful breeder Strowan Butterfly 24th (104,110). Lawton Schoolmaster, a handsome red two-year-old, sold at Perth last spring by Sir Kennedy for 400 gs., was sire of the Kirklevington heifer's bull calf. The Lawton-bred bull was a Lady Dorothy by Dunglass 
Chieftain $(115,188)$, and his dam was by Mr Thos. A. Buttar's notable Schoolmaster $(110,095)$ of the Secret family. In good looks the three-year-old red Spency Graceful, bred by Mr T. Lancaster, and by Spency Speculator $(133,715)$, is second to no animal at Nether Kinnedder. Sir Kennedy's stock bull is the red Ramsden Rover, bred by Captain John Macgillivray and sired by Redgorton Expert $(144,814)$, his dam being Mary Ramsden by the Garbity Royal Pride (106,935). Ramsden Rover shows great breeding, and his shade of red is perfect.

Sir Kennedy is to subject the old steading at Blairsgreen to a thorough overhauling. Byres and bull-boxes are to receive first attention. With regard to Shorthorn developments, much will depend on the course of events. Should it be considered desirable to work into a fairly large herd, the owner of the estate might take over another of his farms. Meanwhile his intention is to refrain from haste in the red-white-and-roan pace.

\section{Newton of Stracathro.}

Mr Archibald V. Cameron, who has owned the compact kindly-lying farm of Newton of Stracathro for four years, began to select a few Shorthorns about 1909. Being near Westside, held by his father and uncles, it was but natural that his first pick of female animals should be from his experienced relatives. He set off with members of the Mina, Revelry, Lady Sarah, Blanche, Barrington, and Waterloo families, 
the first noted having come originally from Fettes, and to these a few years later he added a Lady Dorothy and a Shethin Mysie from Mr Napier, Nether Dallachy, a Broadhooks from Dalmeny, a Clara from Cromleybank, a Countess from Newton of Insch, a Roan Lady from Collynie, and a Queen of Rothes from $\mathrm{Mr}$ Alexander Crombie, Woodend. In course of the last few years $\mathrm{Mr}$ Cameron has been gradually discarding the English families, and adding to the Cruickshank lines of breeding. Until last year, however, his Mina cow, one of the foundation lot, was fresh at seventeen years old, and he had fine members of the Waterloo, Blanche, Lady Sarah, and Revelry families. These had, of course, first-rate Scotch top-crosses, and they held their own well in Shorthorn character against the fashionable Cruickshank representatives.

The first bull used at Newton was the red Westside-bred Stracathro $(100,776)$ by Regal Star $(87,061)$, out of Westside Gladys Waterloo by Extraordinary $(76,640)$. The junior got the use of Westside bulls also at that time and for three or four years later. Then he followed with Keir Masher (109,033), a red Marigold by Lord Elgin $(89,117)$, from a dam by Royal Charter (84,585); Clipper Dairyman (105,048), a dark roan member of the Dairymaid family by Westside Clipper (101,095); Colonel A. T. Gordon's Arclight $(113,917)$; the short-legged Nether Dallachybred red Clipper Monarch $(135,769)$; and the magnificent white Beaufort Snow King $(140,873)$, the fourth-prize winner at Perth in 1918 and second 
recently at the Aberdeen Highland Show. Of the Broadhooks family, very level, and up to wonderful scale, the white cost 1650 gs.

Mr Cameron has been steadily improving buildings and making his homestead more completely adapted for a Shorthorn herd. Westside is an inspiration, and his own instinct ought to carry him far.

\section{ORCHARD FARM.}

At Orchard Farm, near Cambus, on the northern side of the Forth opposite to Throsk, Mr John Finlayson, son of $\mathrm{Mr} \mathrm{Wm}$. Finlayson, has been breeding Shorthorns for a number of years. Mr John Finlayson took up farming at first in Herts. He came north to Orchard in 1910. His first purchase was made in 1909, when he acquired the cow Holker Waterloo 2nd, bred by the Duke of Devonshire, and by Emperor of Oxford $(83,426)$. In 1910 that cow calved a very good red heifer by Gondomar $(95,359)$, but unfortunately the calf rolled into one of the deep Forth-side ditches and was drowned. The next purchase was that of Waterloo Lady, a red roan from $\mathrm{Mr}$ Wm. Jackson, Hillend, Hitchin, and by the Barrelwell-bred Sharpshooter (90,093). The dam of the cow, which had been bred by $\mathrm{Mr}$ C. H. Jolliffe, had for sire the well-known Handsome Boy $(76,832)$. Waterloo Lady produced four very good calves at Orchard. A very finely-bred roan Augusta heifer was selected from Sir Herbert Leon of Bletchley. This was Angela by Ascott 
Wanderer $(101,295)$, which was from a dam by the Collynie Silver Mint $(79,968)$. She was consequently of the same line of breeding as Lothian Augustus $(116,354)$. Her first calf at Orchard was a bull, but before she came round to her second calving she was ditched and drowned. Other purchases made by $\mathrm{Mr}$ Finlayson included Polmaise Juliet, a red Dairymaid heifer bred by Major Murray, and by Dalrannoch Archer $(94,822)$; Fairy Queen 5th, an old Queen of Rothes cow bred at Rhynie and sired by Ringleader's Heir $(67,739)$; and Duchess Broadhooks 11th, a beautiful roan heifer from Throsk, and by Doune Diamond 2nd $(105,288)$, out of Duchess Broadhooks 4 th by Lavender Fancy $(89,047)$.

Polmaise Juliet did fairly well as a breeder. The Queen of Rothes bred until she was over eighteen years old, her produce at Orchard being two heifers and three bulls. One of the heifer calves, a dark roan by Doune Goldsmith $(111,559)$, was sold to $\mathrm{Mr}$ W. T. Malcolm. The Broadhooks has proved a grand breeder. She has produced seven heifer calves and one bull. With the exception of a Lady Dorothy heifer calf, Mr Finlayson's Shorthorns are now confined to the old Broadhooks cow and three of her daughters-all first-class animals. The Lady Dorothy, a dark roan by Flight Lieutenant, a grandson of the Naemoor Edgcote Masterpiece, was bred by Mr H. O. Ritchie, Netherley, Stonehaven.

Orchard is a typical Forth-side holding of about 200 acres, of which 30 are on an island in the river. Rising ground and mixed woodlands shelter it from 
north and east, and it has an upper outlook when trees are bare towards the county and the town of "The Rock."

\section{Polmaise.}

Major A. B. Murray's fine herd at Polmaise reflects high credit on the past and present estate agentsMr J. T. M'Laren and Mr Alexander Robertson. A few Shorthorns, chiefly of Bates and Booth blood, were kept at Polmaise many years prior to 1899 , but no representatives of those cattle are now in the herd. At Colonel Munro's Mains of Murthly sale in August 1899, Mr M'Laren made a very fortunate purchase in the roan Shethin-bred Lovely 46 th by Prognosticator $(66,092)$. She proved an excellent breeder, and left a large number of calves, several of which were of unusual merit. To Record of Sanquhar she produced Polmaise Handsome Prince $(96,423)$, which won fourth prize in the younger class at Perth in 1906, when he passed into the possession of Sir John Gilmour at 170 gs. He was retained at Montrave until he was over eight years old. Several of the highest-priced animals at the Montrave dispersion sale in October 1917 were by him. Polmaise Lovely Baroness, by the very pretty show bull Baron Butt $(48,309)$, was a valuable daughter of Lovely 46 th. She was a prominent winner at the county shows, and she bred several bulls which were sold at good prices. Those included Polmaise Ossian, which was exported by the late Mr Donald Maclennan, and Polmaise Proud Baron, the Perth fourth-prize winner 
in the younger class, 1914. The latter, which was by the highly successful Proud Massa $(109,776)$, passed into the possession of the Messrs Law, Mains of Sanquhar, and a son of his became the sire of the Balnabeen Gipsy Lad, which was sold at Perth in 1918 for 2000 gs. Polmaise Royal Baron was another bull of the Lovely line of breeding. He was the sire of some high-priced animals sold at the Messrs Peterkin's draft disposal in 1918. Lothian Laird $(112,374)$, the noted stock bull owned by Mr Alfred H. Reid of Hillhead, is from a daughter of Polmaise Lovely Baroness. The Lovelys are deservedly appreciated at Polmaise.

A few members of the Waterloo family are in the herd. One branch is descended from the Rosehaughbred Waterloo Lilias, a daughter of the Highland Society winner Watchword. She was acquired in 1899. Another branch came from Ruddington Hall in 1906, the purchase then made being the massive red roan Marengo's Lady Beauty by the champion Marengo. Lady Beauty's first calf at Polmaise was the handsome red Jubilant $(99,240)$, by Ruddington King Edward. Jubilant was bought at Perth by Mr Duthie for $350 \mathrm{gs}$., and was used several seasons at Collynie, where he became the sire of Lavender Victor, Proud Jubilant, Collynie Marshal, Diamond Jubilee, and a number of first-class females. Polmaise Marengo, a grandson of Lady Beauty, took third prize at Perth in 1911, and was sold to $\mathrm{Mr}$ Maclennan. At the Ruddington sale also Bright Ruby of the well-known Dunglass family and by 
Lordly Archer $(70,839)$ was bought, and her line of breeding is still represented in Major Murray's herd. One of the best bulls of the strain, Pride of Polmaise, was effectively used by the Messrs Peterkin.

Two cows which proved excellent breeders were bought at the Pitcur sale in October 1903. These were Agility of the Matadore family and by Activity $(73,942)$, and Zara of the noted Groat line of breeding by Marksman. The best animals out of the Matadore cow were a red heifer by Strowan Marquis 14th and the well-known red bull Lord Matadore by Millicent Chief $(96,096)$. Lord Matadore stood fifth in his class at Perth, and there he was bought at 410 gs. by Mr Duthie, who used him at Collynie for several seasons. Polmaise Zara, an excellent heifer out of the Pitcur Groat cow, was sold to Colonel Johnston, and she became the dam of the famous stock bull Red Baron, which has been such a remarkable success in the herd of the Right Hon. F. Wrench. Another heifer out of the same cow, Polmaise Zarina, was the highest-priced female of her year in the Argentine. Unfortunately the Pitcur cows did not produce other heifer 'calves, and their families are not now represented in the herd.

At the dispersion of the late $\mathrm{Mr}$ Wm. S. Marr's herd in 1904, Clara 62nd by Bapton Favourite was taken for Polmaise. Several of her descendants are now in the herd. Polmaise Nimrod, the fourth-prize winner in the younger class at Perth in 1912, Polmaise Top Knot, King Coral $(102,677)$, and Polmaise Clara 2nd, a first prize taker and reserve champion 
at Edinburgh in 1910, are of this family. A Sittyton Dairymaid from Beaufort produced Polmaise Julia, the second-prize two-year-old heifer at the Stirling Highland of 1909. The Lady Dorothy family has done remarkably well at Polmaise. The foundress was Lady Dora, a Royal Mint heifer acquired from Jackstown in 1909. A Queen of Rothes was added from Ballachraggan in 1911. One of the most fortunate of purchases was made in the same season at the Pirriesmill dispersion sale. That was Eliza 32nd by Golden Clipper. A noted bull of this family was Polmaise Quartermaster, the second-prize winner and reserve champion at Perth in 1915. Recent purchases of females include a Secret from Mains of Murthly in 1913, a Brawith Bud from Ballachraggan in 1915, an Orange Blossom from West Fingask in the same year, a Clipper from the Messrs Young in 1917, a Broadhooks at the same time from Mains of Sanquhar, and an Augusta from Boquhan in 1918. The Clipper had for sire Redgorton Dandy, the highest-priced bull exported to the Argentine in 1917.

Stock bulls have been selected with great discrimination. The most successful have been Record of Sanquhar; the Beaufort-bred Millicent Chief $(96,096)$, of the Julia or Dairymaid family; Proud Massa $(109,776)$, bred at Hean Castle and by the Collynie Proud Champion $(10,096)$; and the present stock bull, the white Redgorton Dictator $(133,019)$. The herd has been specially indebted to Millicent Chief and Proud Massa. 
On only one occasion during the last ten years have the Polmaise bulls been out of the prize list at Perth. In 1909,1910 , and 1915 the herd provided the reserve groups. Surplus heifers have been sold privately to home breeders and for export to the Argentine and South Africa. Mr Robertson's skill and care have been admirably backed in recent years by James Hay, the expert herdsman.

\section{Priestgill.}

At high-lying Priestgill in the Strathaven district of Lanarkshire, Mr Thomas Dykes has been breeding Shorthorns for about fifteen years. His first purchases of consequence were a Mysie by Gold Bank (86,063), from Messrs Calder of Ardargie, and an Emmeline by Mercury's Farewell $(99,609)$, from the late Mr Robert Menzies, Tirinie, Aberfeldy. Those females proved excellent breeders. A few years ago he bought at one of the Collynie sales the pretty calf Broadhooks Beauty by Regal Crown $(117,292)$, and two years later he acquired a Clara from his neighbour, the late Mr John Watson, Kirkwood House. Mr Dykes has twelve breeding cows of the families just noted. His principal bulls have been Clipper Rosemount $(114,730)$, bred by the Messrs Cameron, Westside, and by Rosemount $(109,965)$; Rosemary Beau (122,528), bred by Mr R. Wylie Hill, and by Proud Beau 3rd $(106,627)$; Boquhan Augusta Prince $(529,748)$, of Mr Stephen Mitchell's breeding and by Collynie King Royal (114,768); and the bull now 
in use, Secret Signal $(145,342)$, a handsome light roan, bred at Cromleybank and by Prince of Orange $(117,052)$, out of Secret 11 th by the famous Royal Crown (84,598).

Mr Dykes, who owns his farm, is handicapped to some extent in bringing out his cattle by a late district. His steading is about 700 feet above sealevel, and most of the soil is over boulder-clay. In autumn the stock have a great appearance for hair. Some hedges break the sleety blasts which come early across the neighbouring moors, but $\mathrm{Mr}$ Dykes is frequently enough reminded by critical friends that he is not in a "Shorthorn country." Still, the herd is a credit to its owner, and to the wonderfully accommodating nature of the breed. The cows have sweet heads and generally excellent bags of milk. The much-admired red bull Emmeline's Beau $(136,405)$, with which $\mathrm{Mr}$ W. T. Malcolm was so prominent in the prize lists last season, was bred at Priestgill, his sire being Rosemary Beau and his dam the old cow by Mercury's Farewell. For some years the late Mr John Watson bred a few Shorthorns of the Clara, Brawith Bud, and Graceful families, and Mr David Stewart of Blantyre Park has been keeping a small collection descended from Mr Charles E. Law's Graceful 21st by Baron Broadhooks (101,398).

In the Shorthorn sense $\mathrm{Mr}$ Dykes occupies an isolated position. $\mathrm{He}$ is aloof from the thrill and stimulus of the red-white-and-roan breeders, and yet he has evolutionary pleasures of his own near the hills. His herd is one of the many examples of 
what can be accomplished in a quiet way by using first-class bulls and retaining the best heifers.

\section{RACHAN.}

Peebles as a whole is more of a flockmaster's county than an arable and cattle-breeding area, but at picturesquely situated Rachan, with its guardian Drumelzier, Stobo, and other hills, Mr Henry B. Marshall, the owner of the estate, has made a reputation as a breeder of Clydesdale horses, and he is now in the strong army of Cruickshank Shorthorn breeders. Six years ago he made an excellent start with the red-white-and-roan, and since then he has been one of the most enterprising of bidders for the very best. At Colonel Munro's sale in 1914 he acquired Charity 16th, a red Newton-bred two-yearold Clipper by President of the Mint $(109,670)$. That proved a highly fortunate purchase, as the fashionably bred female produced four heifer calves in succession at Rachan, her first being a roan by the Collynie Merry Victor $(116,563)$, her second a red by Doune Warlock $(125,229)$, her third and fourth a roan and a red by Throsk Masterpiece (133,934). In 1919 she had a red bull-calf by the Crieffvechter-bred Captivator (141,429). In $1915 \mathrm{Mr}$ Marshall bought a beautiful light roan Augusta from Mr Robert Duncan, the well-known breeder and exporter. That was Augusta 130th by Marmion (10,933). From her three heifer calves have been bred. Another Clipper, and a specially valuable one, was secured the same season 
in the two-year-old Boquhan Consolation by Collynie Cupbearer $(105,069)$, out of Proud Clipper by Proud Monarch $(92,961)$, and with the back crosses of Corner Stone, Mario 2nd, and Star of Morning. Here again Mr Marshall has had the foundation good fortune of two heifer calves, both reds.

Two years ago very much admired yearling heifers were added to the herd in the Messrs Munro's Perth second-prize Lavender 70th by Collynie Clarionet (124,840); Messrs Robertson's (Cloichfoldich) Lady Rothes, a dark roan by the noted Keir Quartermaster $(120,896)$, and Major Graham Stirling's Clara 14th, a red by Dunglass Guardsman. The Lady Rothes was dam of a red bull, Rachan Litigant, which drew 380 gs. at Perth in the spring of 1919. The Clara bred a fine roan heifer calf in 1918, and she followed with a good red bull calf by Captivator. Some important purchases were made in 1918. From the Ballechin group of yearling heifers a Jenny Lind by Favourite Lancer $(125,520)$ and a Rosewood by Royal Leader $(103,727)$ were selected, and a very fine Brawith Bud by Collynie Cruickshank $(105,068)$ was taken from the Duchlage lot. Cullisse Symmetry, an exceptionally well-bred red yearling of the Secret family, was secured at the sale of the late Mr John Gordon's cattle. She cost 450 gs. A dark roan Saltounbred Butterfly at 300 guineas came in well shortly afterwards. Heifers and heifer calves were taken out of the Aberdeen ring in October at high prices. These included a fine roan Fairy Queen from Woodend and by Brave Marquis $(119,158)$; a red Broad- 
hooks from Throsk and by Collynie Golden Boy $(130,288)$; a white Broadhooks calf from Balnakyle; a roan Rosebud from Mr M'Allister and by Adbolton King Tulip $(129,026)$; a red Clara from Strowan; a white Eliza from Tulliallan, and a dark roan Princess Royal by Millhills Rothes King from Clunes. The last-named cost 850 gs. A notable addition was made to the herd last year in Mr W. M. Cazalet's Cardiff Royal female champion Proud Dorothy, bred by $\mathrm{Mr}$ Duthie and by Lothian Augustus (116,354).

Mr Marshall is exceedingly fortunate in having such a large collection of Clippers tracing back along two highly-prized lines to the famous Sittyton foundation cow. The Augustas will soon be in prominence also at Rachan, and the closely allied Rosewoods should be safe, as Ballechin Rosewood has bred a pretty heifer calf. There is not an overplus of Secrets in Scotland, but the Cullisse acquisition has bred a promising heifer calf at Rachan. In the two-yearold heifer group, the Princess Royal, the Rosebud, the Eliza, a Clara out of Strowan Clara 14th, and a Clipper are the best. These by themselves would form a very fine foundation for a herd. Last year 28 cows and 5 heifers came to the calving, but in all probability the herd of breeding cows will not be regularly run into a larger total than 30 head. The fortunes of the herd will be followed with great interest. Mr Marshall's enterprise and enthusiasm deserve rewards in calf crops, prizes, and prices.

The principal bulls used by Mr Marshall have been Doune Warlock $(125,229)$, bred by the Earl of Moray; 
Throsk Masterpiece (133,934), bred by Mr William Finlayson, and Captivator (141,429), a blocky red three-year-old now in use and sire of some excellent calves. Bred by $\mathrm{Mr}$ William A. Dron, he is by Cupbearer of Collynie $(114,960)$ from a Pride cow by Broadhooks Victor 2nd $(101,658)$, grandam by Golden Gift $(81,168)$.

Rachan home farm has an extent of about 460 acres, of which 360 acres are arable. At the steading the elevation above sea-level is 500 feet. Most of the soil is a fairly deep loam over sand or gravel, the remaining being clay over sand. For cropping purposes a proportion of the land is too sheltered, the lower grounds of the estate being well wooded, but an effort is made to keep the plough agoing mainly on the more open sections. Buildings have been much improved and brought into line with Shorthorn requirements.

\section{REDGORTON.}

Mr Anthony George Maxton Graham of Cultoquhey and Redgorton represents the old families of Maxton of Cultoquhey, and Graham or Graeme of Garvock, afterwards better known as of Balgowan. Mr Thomas Graham of Balgowan, M.P. (Lord Lynedoch), already referred to (page 6), was the most noted modern member of the Grahams. He died without issue in 1843 , and was succeeded by his second cousin, $\mathrm{Mr}$ Robert Graham of Balgowan and Redgorton, who sold Balgowan in 1844. He also died childless in 1859, and was succeeded by his nephew, Mr James Maxtone 
of Cultoquhey, father of the present proprietor. $\mathrm{Mr}$ Maxtone, who obtained a patent to bear the name and quarter the arms of Graham of Balgowan as heir of that family, died in 1901.

In its history of nearly sixty years, the Redgorton herd has had the distinction and the privilege of being under the direction of two men, both masters of their business-the late Mr James Fenwick and his son, the present agent, Mr James Fenwick. The herd was founded at Cultoquhey in 1861 with the Keir cow Christina by John o' Groat, her pedigree tracing back to Fancy by Captain Barclay's Billy (3151). At Cultoquhey Christina became the ancestress of the Daffodil family, a notable one in the showyards. George 3rd $(49,638)$, a bull of Mr William Turnbull's breeding, appears two removes beyond the first Daftodil. From Huntingtower in 1870 there was also acquired the cow Myanza by Knight of the Rock $(24,279)$. The Redgorton Lilys, which have been somewhat crowded out in recent years, were descended from the cow just noted. A roan bull Cupbearer, from the Huntingtower cow, won the silver trophy at Crieff as a calf, and next spring he took the 10-gs. cup at Messrs Macdonald, Fraser, \& Co.'s spring show. In 1869 Vanity by Forth $(17,856)$ and the yearling bull Orthodox were bought privately at Sittyton. The Fairy Queen family, which is now in strong force at Redgorton, is from Fairy Queen 5 th by the Sittyton Greyfriar $(46,466)$. She was bought at the Cairnbrogie dispersion sale in 1886. Many members of this fine family have been exported to the Argentine and 
other countries. In 1903, Catherine 2 nd by Mr Heineman's Royal Lamorby $(59,830)$ and her heifer calf Cluny Crocus by the Collynie Royal Pride $(71,489)$ were bought at Lady Cathcart's sale. Cluny Crocus developed into a magnificent show cow, and for all her wealth of flesh she proved a great breeder and founded at Redgorton a family of wonderful all-round merit. She was first in the cow class at the Aberdeen Highland of 1908, and took championships at Edinburgh, Perth, and Crieff. The Miss Ramsden cow Lady Lincoln 5th by Mr James Bruce's Belted Knight $(56,933)$ was acquired at Colonel Munro's sale in 1905. Her best-known daughter has been the champion Belle of Lincoln by the Uppermill Royal Bounty $(89,907)$. The Miss Ramsdens now take a strong position in the herd, as they have proved exceptionally fine breeders. In more recent years females of the Broadhooks, Clara, Graceful, and Kilblean Beauty families have been added to the herd. Other strains have been tried at different times and dispensed with.

Some of the best bulls in the herd may be named. From Sittyton there were bought privately, between 1868 and 1886, Aidecamp $(30,364)$, Schoolmaster $(39,086)$, and Dauntless $(54,155)$, the last noted being so famous in after years at Ballechin, Collynie, and in Yorkshire. Knightly Friar $(41,773)$ was taken from Mr Fisher's herd in 1877. Two years later Sir Walter $(45,627)$ from Kinellar marked a return to the Scotch type. Prince Charlie $(51,875)$ in 1884 , and Hubback Junior $(59,123)$ in 1889 , were fine stock bulls from the herd of Mr George Bruce. 


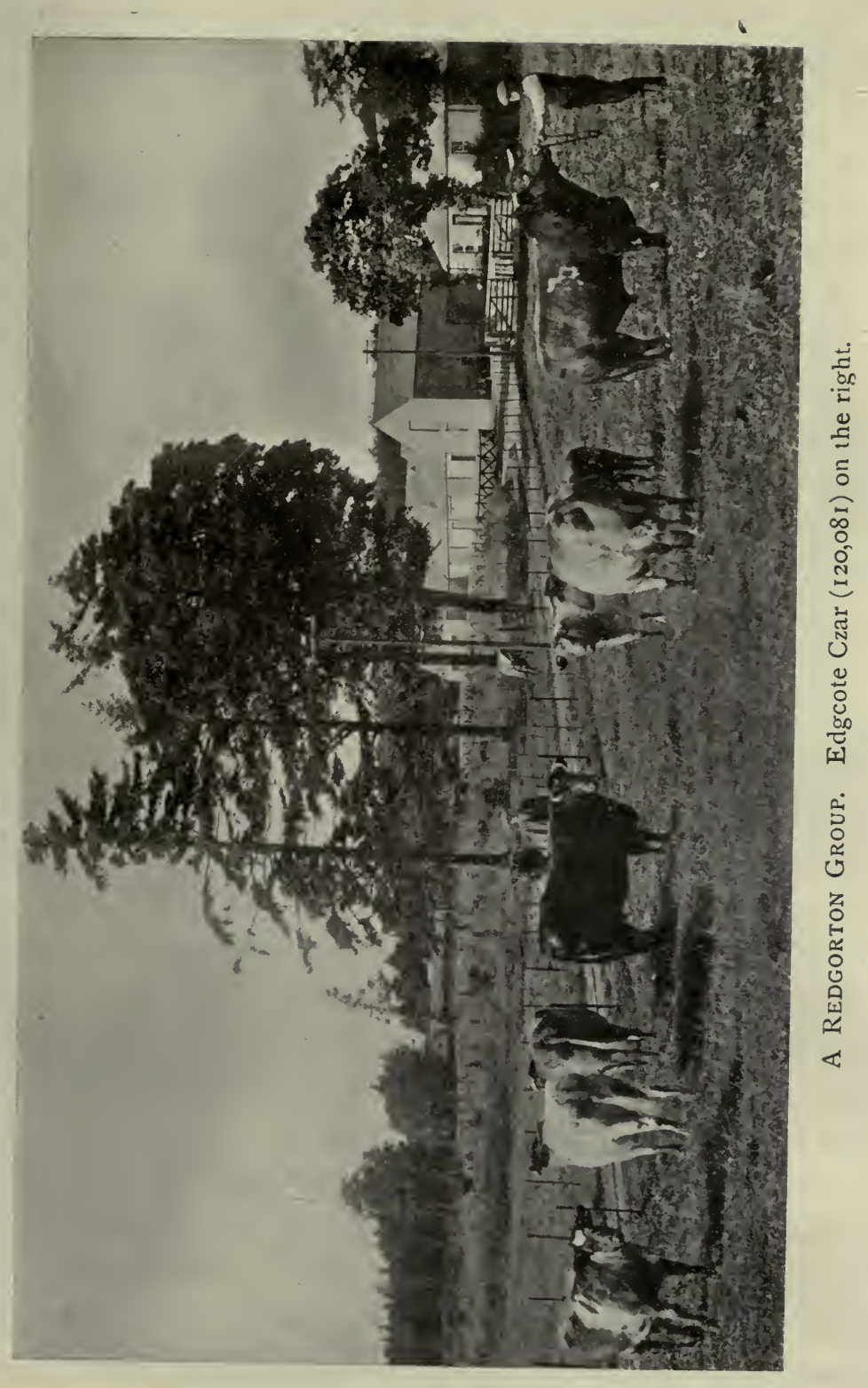



From Uppermill there followed, in 1893-96, excellent breeders in Man of War $(65,886)$, Swordsman $(69,689)$, and King's Favourite $(70,719)$. Prince of Masters $(73,305)$, a selection from Collynie in 1897 , left some first-rate stock. White Archer $(78,144)$ came from Montrave in 1899, and Knight of Rosewood $(79,171)$ from Collynie in 1900. These were followed by Royal Bounty $(89,907)$, from Uppermill in 1904, Pride of Livet $(109,678)$, from Garbity in 1910, and Royal Crest $(113,146)$, from Newton of Insch in 1911. Exported to the Argentine, Royal Crest was sold there for $£ 3600$, his buyer being the noted breeder $\mathrm{Mr}$ Leonardo Pereyra. One of the best stock bulls ever used in the herd, Edgcote Czar $(120,081)$ by Collynie Marshal (105,071), from a Charlotte Corday dam, was bought back in 1919 by Mr Wallace his breeder, and is now stationed at Balcairn, Aberdeenshire. The stylish show bull Collynie Clarionet $(124,840)$ by the champion Strowan Clarion (110,333) was a 1914 purchase. He was exported to the Argentine as a twoyear-old, and sold there for $£ 960$. Edgcote Czar has a high-class successor in Newton Grand Duke $(138,201)$, a dark roan bred by the late Colonel A. T. Gordon, and by the front-rank sire Grand Champion (120,527), out of the famous old breeder Countess 17th, the dam of Count Fascinator, Count Crystal, Count Scarlet, Countess Crystal, and other noted animals. Very few female animals from the herd have been sent to public sales. Surplus heifers have been sold privately as a rule for the Argentine, South Africa, the United States, and Canada. In 1889 a draft of 21 was sold 
to Messrs Nelson \& Sons for export to the Argentine, and in 1900, 14 cows and heifers were sent to a wellknown breeder in the great South American republic. In 1917 six females were sold to Messrs Carpenter \& Ross, U.S.A., and almost every year a few have been disposed of to $\mathrm{Mr}$ James Sidey and other exporters. Still there has been little departure from the sound principle of retaining the best for the herd.

Comparatively few heifers have been exhibited at the summer shows outside the county, and the Perth Spring Shows have been the standard fixtures for display of bulls. In 1874 the Lily bull Cupbearer won first at Perth, and sold at $63 \mathrm{gs}$. to Sir Simon Lockhart, and in 1889 and 1897 bulls of the same family won first and second respectively, the latter going to Mr Donald Maclennan at 86 gs. In 1900 the Daffodil bull Royal Chief led at Perth, and Mr Maclennan took him at 200 gs. Two years later a Daffodil and a Lily bull won first and second, and with a third they took the group prize. The single winner fell to Mr Maclennan at 135 gs. Coming down to 1912, a handsome bull of the Lily family was sold in the Perth ring at 150 gs., and in Buenos Aires he drew $£ 1835$. Between 1904 and 1914 Daffodil bulls won first and fourth, and a Miss Ramsden bull led in two-year-olds. The last noted was the much-admired Brutus, the leader of the seniors in 1914, and for him Mr Maclennan paid 710 gs. A great bull was seen in 1915 . That was the Daffodil, Redgorton Cruiser, which won 
the Maclennan Cup, and led the first-prize group. His price in the ring was 620 gs., but in Buenos Aires he realised £2530. A year later Redgorton Duke, a Crocus bull, was taken out of the ring by Mr Sidey at 500 gs., and he reached $£ 980$ in the Argentine. Mr Young, the buyer of Redgorton Dandie, another member of the Crocus line, paid 290 gs. in the ring, but his selection drew $£ 2700$ on the other side of the water. Miss Ramsden, Crocus, and Fairy Queen bulls did well in 1917, while the Crocus, Redgorton Emissary, and the Daffodil, Redgorton Ensign, carried off second prizes in the December and January classes of 1918. These were bulls of grand substance by Edgcote Czar and the home-bred Redgorton Duke (133,022). Mr Joseph Shepherd took those bulls at $1100 \mathrm{gs}$. and $800 \mathrm{gs}$. for export.

Most of the land near the farm buildings is well sheltered. Some of it tends to burn during a dry summer. North-facing fields farther away are of stronger soil, and on them the stock have some cold blasts at the fall of the year. The land all over is naturally inclined to produce animals of good scale. They certainly do well in their winter quarters, which are excellent for comfort and airiness. Seen on the pastures, the cows impress one by their combination of size, beef, and milk. Shorthorn character is distinctive, and there is sensible refinement of bone. Since the early nineties of last century the herd has been entirely kept at Redgorton. 


\section{SALTOUN.}

Much may be expected from the herd which has been built up during the last five years by Captain Andrew Mansel Talbot Fletcher, the representative of a very old and notable Scottish family. Saltoun Hall, at the edge of a rich plateau, is magnificently set off by great hardwoods, conifers, and ornamental trees. Through rifts it overlooks a charming grassy haugh through which the Saltoun stream curves on its way to join the Tyne, and just outside the policies it is in touch with a great deal that is agriculturally best in a fine countryside. The main part of a spacious and substantial farm-steading is old, but the homestead has been subjected to skilful overhauling and extension in the interests of fresh air, light, and comfort. An excellent double byre, with plenty of space and the very best ventilation, is one of the newer features. Bull-boxes, separate from the main block, are on the most approved model. In laying his foundations, Captain Fletcher struck out boldly without waste of time. He was the principal purchaser of cows at the dispersion sale of the famous Newton herd owned by the late Lieutenant-Colonel Alexander T. Gordon. At that disposal he selected from the list of cows a Miss Ramsden, a Jenny Lind, a Maude, a Butterfly, a Clara, and an Augusta. From the yearling heifer group he took a Princess Royal, and from the heifer calves a Mary Anne of Lancaster. Those animals, along with a number which had been 
bought privately from Newton, gave the Saltoun herd a first-class start, the blood of such grand bulls as Ruddy Star $(73,555)$ by Star of Morning; Mario 2nd $(59,439)$ by the Champion Mario; the Collynie Prince of Ceremonies $(92,903)$; Violet's Victory $(85,001)$; Newton Crystal (92,658), and Grand Champion $(120,527)$ being in prominence.

In 1917 a Bellona was bought from Mr Morrison, Phingask, and a Butterfly from Mr George Campbell of Bieldside, Inverurie. The Butterfly was in calf to the Collynie Red Knight, and at Saltoun she produced the handsome red bull calf Brave Knight, which won first and special at Darlington, and was then sold for export. A very fine Sittyton Violet was selected from Newton that season, and to Lord Advocate she bred a pretty heifer calf which was sold to Mr Wylie Hill for 230 gs. A couple of Clippers, bred at Montrave, were bought from $\mathrm{Mr} \mathrm{Wm}$. T. Malcolm. One of these, the beautiful first-prize cow at Edinburgh, unfortunately failed to breed, but the other bred to Collynie Silver Knight a fine roan heifer calf, which was sold at Aberdeen for 220 gs. At Mr James Durno's Uppermill sale in October 1917, Captain Fletcher secured at 350 gs. a stylish red Orange Blossom heifer calf by Collynie Golden Flash $(119,546)$, out of Orange Bloom, the grandmother of the heifer calf which was sold a few minutes earlier to the Prince of Wales for 800 gs. Zoe 32nd, a very finely bred Clipper, was an addition from Mains of Sanquhar.

The Newbus Grange sale in the same month pro- 
vided another good opportunity for Captain Fletcher. At that sale he acquired at 420 gs. the handsome red six-year-old Clipper Baroness by Prince of the Blood $(96,532)$, and in calf to Quartermaster (132,925). From Mrs Scurfield's draft he selected at the same time a young Broadhooks cow with heifer calf at foot, a Golden Drop yearling heifer, and a member of the old Northumberland Rose family. At the Rothiebrisbane sale in 1918, Captain Fletcher took out three remarkably good-looking females of the noted Myrtle family. Myrtle Sylvia, a red threeyear-old by Golden Sittyton $(106,643)$ at 310 gs., Myrtle Poppy 2nd, a roan two-year-old by Collynie Premier $(124,847)$ at 410 gs., and Myrtle Duchess 2nd, a roan heifer calf, also by Collynie Premier, at 240 gs. were the selections. In addition to the foregoing, Captain Fletcher has handsome cows and heifers of the Princess Royal, Secret, Crocus, Lady Dorothy, Lavender, Claret, Bessie, and Newton Countess families. The Princess Royal came from Newton; the Secret, which was of Uppermill breeding, was a selection from Mr Malcolm's herd; the Crocus was a purchase from the Albert Agricultural College Farm, Ireland; and the Lady Dorothy, a Darlington choice, was from Mr E. R. Turton's herd.

For principal stock bull, a great breeder was selected at an early stage in the Newton-bred Burgomaster $(124,176)$. That was a red son of Champion of Scotland (111,261), out of Bessie 75th by the Royal English winner Bandmaster $(97,929)$. Before leaving Newton he had his spine seriously injured by a barbed 
wire in a hedge, and the wound was not noticed at the time. He was used only one season at Saltoun, when he collapsed, but he left his mark. There was not one indifferent calf by him, and all were rich colours. Probably his best young bull was the prettily-shaped red Postmaster out of Pauline 11th, a Newton Crystal cow. Postmaster was sold to the Messrs Cameron, Westside, for 650 gs. Last year another son of Champion of Scotland was bought as as old bull in Ireland. That was the massive light roan winner of many prizes, Newton Renown $(121,779)$ of the Rubyhill family. At Perth, in 1918, the Earl of Moray's big and very evenly-fleshed third prize two-year-old red, Sanquhar Grand Courtier $(139,193)$, was secured at 750 gs. $\mathrm{He}$ is by Collynie Grand Knight $(119,549)$, from a Rachel cow by Hawthorn Champion $(99,098)$, grandam by the Ballechin Tom Bowling $(97,441)$, then back to Captain of the Guard, Athabasca, and Heir of Englishman. $\mathrm{He}$ stood third in a very strong class of aged bulls at the Edinburgh Highland.

Captain Fletcher has taken exceptional precautions to secure healthy stock, and to keep them in sound condition. All animals introduced into the herd are isolated and subjected to the tuberculin test, and also to the equally necessary abortion test, the latter being carried out by Sir John M'Fadyen, to whom a sample of the blood is forwarded. It may be noted in passing that one of the Captain's ancestors kept some Shorthorns at Saltoun over a hundred years ago. The present intention is to keep a breeding herd of about 
40 cows. Captain Fletcher has shown great enterprise in his foundation selections, and a bright future is predicted for his cattle, which are now under the expert guidance of the new agent, Mr J. T. M'Laren, junr.

\section{Softlatw East Mains.}

For at least fifty years Mr James Scott, Softlaw East Mains, has bred Shorthorns, but it is only during the last thirty years that he has attended to registration. In the meantime he has two or three members of the Lochside Marvel family, one being a sweet red cow, Softlaw Marvel 12th, by Mr A. M. Douglas's Royal Guard $(113,165)$, a Brawith Bud bull by Violet Royal $(90,424)$. Softlaw Violet 2nd, a beautiful young roan cow by Tarty Favourite (vol. 64), traces back through Spotsmains and Orchardmains to the Gems bred by Mr Nicol Milne at Dryhope. The most famous animal ever bred by Mr Scott was the red and white Softlaw Rose by Prince Charming $(50,197)$, out of Fairnington Rose by Mountain Prince (61,343), grandam Cumledge Rose by Hotspur (28,876). Mountain Prince was owned by $\mathrm{Mr}$ J. Munro, Fairnington, Roxburgh, and the bulls Red Knight $(24,916)$, Snowflake $(18,888)$, Duke of Buckingham $(14,429)$, and Ravensworth $(7400)$ in the cow's pedigree are entered as the property of $\mathrm{Mr} \mathrm{J}$. Wilson, Cumledge, near Chirnside. Softlaw Rose was a cow of beautiful shorthorn character, of generous scale, very level in her flesh, and a good milker. In $\mathrm{Mr}$ Scott's possession she bred three calves. At the 
Birmingham Spring Show of 1891 she won in a fine class of cows, and was sold for 110 gs. to Mr C. W. Brierley. Primrose, a roan calved in 1888 , and by Prince William $(59,706)$ out of Fairnington Rose, took second prize at Birmingham and was sold to Sir C. H. Tempest, Bart. Primrose 4th, a granddaughter of Primrose, was calved in 1889, sire Earl of Marchmont $(63,956)$. That cow was sold to $\mathrm{Mr}$ William Duthie, in whose herd she bred one or two bulls but no females. At one time Mr Scott owned representatives of the Faldonside Princess family. He entered the red and white Faldonside Princess, calved in 1877 and bred by Miss Milne of Otterburn. Descendants of that cow were in Mr Scott's possession for a good many years. For a considerable term of years Mr Scott had the use of Hoselaw bulls. Afterwards he was more or less indebted to the Messrs Riddell, Greenlees.

\section{Stevenson.}

Seventy years ago Mr Hugh Elder, a representative of an old Upper Ward of Lanarkshire farming race, migrated from the Carnwath district to East Bearford, on the Earl of Wemyss' estate in the Haddington district. $\mathrm{He}$ was finishing the leases of two holdings in the Upper Ward when he took up his tenancy in East Lothian. Mr Hugh Elder, who died in 1897, had his son, Mr Thomas Elder, associated with him for many years, and the family connection with the farm remained unbroken after 
the senior's death. Mr Thomas Elder had been tenant of the neighbouring farm of Stevenson Mains, as it was then named, since 1889 , and he bought the farm over six years ago, shortly after the death of the proprietor, Sir Robert Sinclair, and dropped the "Mains." With his son, Mr Hugh Elder, as joint-tenant of East Bearford, the family is now in the fifth lease. It may be noted in passing that Mr Thomas Elder's grandmother was one of the Somervilles of Lampit, whose names are so familiar to students of Clydesdale horse history. The old racial trait-admiration for a well-bred good animal -takes the Shorthorn course very specially in the case of Mr Hugh Elder.

Pleasantly set in the Tyne valley, Stevenson has an extent of 400 acres arable and 60 acres of woodland. About two-thirds of the farm is of a somewhat stiff nature, the remainder being useful loam over gravel. Part of the land is too sheltered in some seasons for grain-growing, and a section which is rather closed-in is down in old pasture. The steading, which is an old one, has an excess of spreading out. Stallion-boxes used by Mr Adam Smith, the previous tenant, are now convenient for young bulls. Mr Stevenson is erecting byres, and gradually altering the buildings in general for the new conditions. East Bearford is a very good general-purpose cropping farm of 312 acres. The land is a sharp good quality loam, and the steading is an excellent modern one, originally intended for feeding stock, and easily capable of being modified should it be considered 
advisable to transfer some of the Shorthorns to the place.

Prior to 1912, Mr Thomas Elder bought a fine old Mary of Argyll cow and her white bull calf by the Legars Bashful Boy $(85,301)$ from the late Mr Joseph Lee. There are now six descendants of the old cow in the herd. Breeders will remember that Captain John Macgillivray's 2600-gs. bull Aldie Armistice, the Perth reserve champion of last year, was of this family. The calf by Bashful Boy grew into a handsome bull, and was twice first at the district shows. He was then exported to the Argentine. Mr Elder's real start as a Shorthorn breeder was in 1912. At the Aberdeen October sale of that year he bought the red heifer Myrtle 2nd from Balnakyle. She was by Nonpareil Gift $(103,196)$, and her dam was by the Millhills stock bull Proud Favourite $(84,420)$. When she was a three-year-old she produced a pretty red heifer calf, Myrtle's Queen, by the home-bred dark roan Flora's Favourite $(115,413)$. Myrtle's Queen is now the oldest member of her family in the herd. She is dam of the twin yearlings which were sold at Perth last year for 200 gs. each. These were by Throsk Broadhooks 26th $(133,930)$. Other two young red cows in the herd are from the same mother. Stevenson Myrtle, one of these, is a breeder's animal in character and shapes. Attending the Congalton dispersion sale, Mr Elder bought the white Congalton Rosemary 3rd by Dunglass Conqueror (83,377), and her highly promising roan heifer calf by Birdsall Briar (101,547). The calf which $\mathrm{Mr}$ Lee rather 
unthinkingly named Congalton Rosebud grew into a great cow, which might have been exhibited anywhere two or three years ago. She won at Edinburgh in June of this season. The old white cow's calf in 1914 was a dark roan bull sired by Birdsall Briar and named Test Act $(128,475)$. He was used in the herd one season, and left several beautiful females. Congalton Rosebud has been a fine breeder. She has two good-looking daughters in the herd, and the Perth fourth-placed heifer out of her-a month too old for the yearling class-was sold for 200 gs. to Messrs Carpenter \& Ross.

At the Whittingehame sale, Mr Elder took out the breeding-like roan, Lady Dorothy 41st by Ascott Royal (104,568). In calf to the Royal English winner Roving Boy $(127,852)$, her calf of 1917 was a beautifully-shaped white named Stevenson Dorothy. The 41st next bred to Throsk Broadhooks 26th the red Stevenson Dorothy 2nd, one of the best. Then there is a pretty roan yearling, neatly moulded and short-legged, by the Throsk sire and out of Stevenson Dorothy. Mr Elder selected beautiful calves at the Aberdeen autumn sale of 1918 in a red Miss Ramsden from Mr T. L. Anderson's herd at Damside, and by Cupbearer of Collynie (114,960), and a white Butterfly from Towie Barclay, and by Uppermill Knight (134,052). Some might now class the Miss Ramsden as the most valuable breeder in the herd. From the Perth spring sale of last year Mr Elder took home a grandly-bred Aigas Broadhooks yearling by Ambassador $(134,614)$, and from Aberdeen in October he 
took a couple of high-class heifer calves-a Balnakyle Butterfly and a Cluny Orange Blossom, the former by Edgcote Wanderer (vol. xliv.), the latter by Collynie Grand Duke (124,844). The Butterfly cost 400 gs. and the Orange Blossom 420 gs. At the North Loirston sale Mr Elder paid 340 gs. for a fiveyear-old Secret cow by the Saphock Gipsy Boy (111,535).

To sum up, the families in this interesting herd of fine-looking cattle are the Butterfly, Orange Blossom, Rosemary, Broadhooks, Secret, Myrtle, Lady Dorothy, Mary of Argyll, and Miss Ramsden.

The best breeding bull used in the herd has been the massive red Throsk Broadhooks 26th. There is much promise in the roan yearling Newton Royal Beau, which cost 400 gs. as a calf. $\mathrm{He}$ is by the Clipper bull Newton Cossack (vol. lxv.), and out of a cow of the Beauty family by Lothian Regal Star $(126,644)$. This yearling, which took third at Edinburgh, shows a great deal of breeding.

\section{StrowaN.}

Shorthorns have been bred at Strowan since 1842, but for the first twenty years of its existence the herd was a small one. In 1870 the cattle were sold off with the exception of two favourite animals. It is to one of these, Lady Groat by the noted Cruickshank bull Lord Chamberlain $(22,129)$, that the herd has been so greatly indebted. She was bought as a calf at Keir in 1867, and she founded the Strowan 
Marchioness, Buttercup, and Cowslip families, from which so many prize-winners have been bred. From twenty-five to over thirty years ago the cows of those families, especially the Marchionesses, made a great show in the picturesque policy parks at Strowan. Beautiful in character, with flat, tastefully curved horns, they were of generous substance on short legs. The old features have been well preserved all down the family lines.

Mr Graham Stirling died in 1896, and his son and successor, Major C. Home Graham Stirling, paid his first visit that autumn to the Aberdeenshire sales, where he made highly important selections. At Uppermill he bought Clara 51st, a grand cow by Captain of the Guard from a dam by William of Orange, and she was in calf to Spicy Robin. At Newton he was fully as fortunate, as he there acquired at somewhat easy prices the bull calf Star of Dawn $(71,681)$ by Star of Morning $(58,189)$, and the four-year-old Miriam by Mario 2nd, and in calf to the famous "Star." Before the sale started the late $\mathrm{Mr} \mathrm{A}$. M. Gordon took his visitor around the steading, and pointing to a roan bull calf in a disused pigsty, he said, "If you don't get a bull in the ring you can have this one." The animal thus cavalierly dealt with was Corner Stone, afterwards first-prize winner in old bulls at the Highland, and champion. Some of the most prettily modelled female animals in the Strowan herd at the present time are of the old Booth Bright family, the first of which was bought from $\mathrm{Mr}$ Foljambe of Osberton, Notts. The cows 
have now two or three crosses of Scotch blood. They are thick-fleshed compact cattle, and excellent milkers.

In 1891 the herd scored its first win at the Perth Spring Show with the bull Strowan Marquis by Admiral $(56,797)$. He was sold to the Earl of Rosebery for 62 gs. In 1895 Strowan Ensign by the Stoneytown Defender won; and he passed to Lord Rothschild at 95 gs. Nine years later Strowan Royal Duke led at Perth, and for him there was keen competition, as Mr F. Miller, Birkenhead, had to pay 600 gs. for him. The herd won for the fourth time at Perth in 1910 with Strowan Archduke by the great stock bull Strowan Regent. In this case the winner was secured by Mr Donald Maclennan at 750 gs. The strong man among exporters held that Archduke was one of the best yearlings he had ever acquired in his long career.

A note on the record of the old families in the herd and on the Claras will be of interest. Strowan Marchioness 2nd, a singularly handsome cow with a Bates cross in her, was dam of Strowan Marquis, and she herself took third at the Highland. Mated with Defender, she also produced the magnificent Strowan Marchioness 3rd, which won all the county championships; also first at the Highland of 1898 and reserve for supreme honours, which then went to the two-yearold Star of Dawn, one of the grandest bulls of his age seen for a long time. Marchioness 3rd was not only a wonderful show cow, she was a high-class breeder. Her best daughter was Marchioness 5th, which led at 
the Highland in 1901. She was sold to Mr Kerr Colville for $300 \mathrm{gs}$. The most famous bull from her was Strowan Marquis 13th, a prominent prize-winner at the large open shows, and reserve champion to Linksfield Champion at the English Royal while owned by Mr Rothwell. He was also a splendid success as a sire. In his home herd he left the exceedingly pretty cow Strowan Clayre, the dam of Strowan Clarion, the Birmingham champion for which $\mathrm{Mr} \mathrm{Wm}$. Duthie paid 1500 gs., and in Mr Rothwell's herd he sired the great champion Duke of Hoole.

Buttercup 3rd, a grand-looking cow, was secondprize two-year-old at the Highland Show in 1891, and she was dam of Buttercup 12th, the third-prize winner at the National Show of 1900, and winner of the Shorthorn Society's Dairy Prize. The 23rd of the line was bought at Perth in 1907 by the late Mr Henry Dudding for 430 gs., and she proved a great winner in England, while the 31st was also highly successful in the possession of Sir Richard Cooper. A notable bull of the family was Strowan Butterfly 24th, which was acquired as a yearling in 1908 by Mr George R. Grant of Auchnacree, in whose herd he won a high reputation.

Miriam produced Maid Marion, and she was a vast credit to Star of Morning and to her dam, as she lived to eighteen and gave the herd sixteen calves. Among her produce were the Perth winner Strowan Royal Duke, and Royal Princess, the dam of the remarkable stock bull Strowan Regent, whose young bulls were sold at 360 to 1500 gs. 


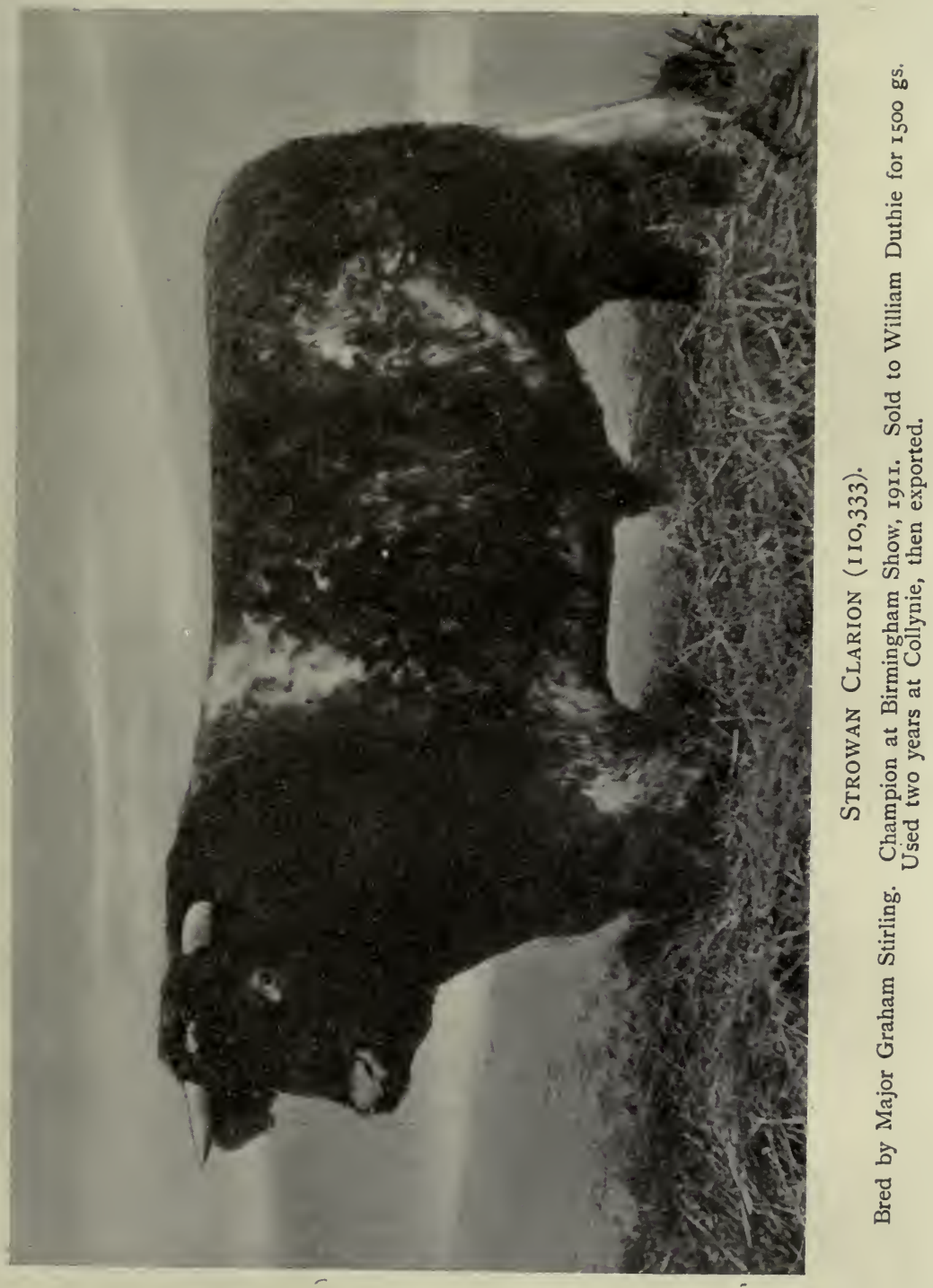



The Claras have done admirably at Strowan. They are exceptionally fine animals to look at, and their record is great. Strowan Mavis Clare by Spicy Robin $(69,038)$ won second at the Highland; Strowan Clare by Montrave Baron $(81,740)$ took third; and Strowan Clare 6th by Strowan Regent took second place. Then in bulls the family produced Cock Robin, a Highland third-prize yearling, afterwards champion at Chicago; Strowan Champion, with a fourth and a second to his credit at the Highland; Strowan Clarion, already noted; Strowan Claverhouse, a firstclass stock bull; and Strowan Clarionet, which was sold to the Edgcote Shorthorn Company for 750 gs. Strowan Clayre by Strowan Marquis 13th was dam of Clarion, Claverhouse, Clarionet, and Clara 6th-a wonderful breeding record.

The herd is kept at a breeding strength of 20 to 25 cows. From twenty to thirty years ago some of the Marchioness females began to wear into white stockings, and in order to cancel that feature the remarkably handsome white Montrave-bred Sportsman $(75,719)$ by $\mathrm{Mr}$ George R. Fortune's stock bull Nimrod $(75,135)$, out of a dam by the Uppermill Michigan (75,086), was acquired, and was most successfully used. That fine bull, which won at the Highland, came between the Star of Dawn and Montrave Baron periods. Major Graham Stirling considers Strowan Regent $(97,347)$ to have been the most consistently good breeder of all the noted bulls ever used in the herd. At the present time the bulls in use are the Collynie-bred red Lord of the Ring 
$(132,041)$ by Esmond $(111,713)$, out of Rose Lynedoch by Lord Lynedoch $(74,900)$; and Balthayock Ramsden $(140,699), \mathrm{Mr}$ Wylie Hill's very pretty roan third-prize winner in the Perth March class, 1918, sire Collynie Golden Star (130,289), dam Lady Ramsden by the former Millhills stock bull Proud Favourite $(84,420)$. In recent years the buildings at Strowan Home Farm have been very much improved, and they are now at once airy, comfortable, and convenient. The young stock always do well in their winter quarters.

Much of the success of the herd during the last quarter of a century has been due to the watchful care exercised by the faithful old manager, Mr Alexander Stewart, who has been at Strowan since 1882, and in full charge of the home farm since 1896.

\section{Swinnie.}

On breezy Swinnie, near Jedburgh, with a Blackface sheep - run beyond the arable grounds, $\mathrm{Mr}$ Richard Davidson, a true Borderer, and keen sportsman in his younger days, has bred Shorthorns since 1876, the year in which Mr Nicol Milne, Faldonside, died. Mr Davidson then bought Prince Regent Princess, a representative of Mr Milne's Princess family. She was an excellent milker and grand breeder. In 1878 he bought a Dryhope Moss Rose, and in 1889 he added to his growing herd a first-class milker and breeder in Princess Beatrice 6th, from the late $\mathrm{Mr}$ John Thompson, Baillieknowe, Kelso. Mr Davidson 
has sold a good many heifers of the family for the Argentine. At Messrs Bain's dispersion sale in 1904 he took out a good-looking cow in Bright Pearl, but he did not keep her long. Attending the Messrs Law's Mains of Sanquhar sale the same year, he bought Graceful Maid, but she and her progeny were sold off in course of a few seasons. He then settled down to breed the Faldonside Princess, Dryhope Moss Roses, and the Baillieknowe Princess Beatrice families. In his view of things, a Shorthorn cow ought to be a kindly feeder, a good milker, and a hardy animal.

Mr Davidson was induced to show a heifer at the Border Union in 1906. She took a first prize. That was the only occasion on which he exhibited a female animal. He has shown his stock bulls at odd times. At the Border Union in 1906 he took first and the Shorthorn Society's $£ 10$ premium with Violet's Pride $(93,761)$, bred by the Messrs Napier, Dallachy; and in 1914 he had the same distinction, and also the Challenge Cup, with Bellatrix (11,893), bred by $\mathrm{Mr}$ Budge in Ross-shire. Mr Davidson weans his calves in November, and he feeds the young bulls reasonably well for local or Perth sales in spring. He winters his heifer calves in open courts, with turnips and straw, and a small allowance of cake. All the cattle, however, have as much as possible of the simple life in the fields so long as the weather is fairly good. $\mathrm{Mr}$ Davidson has given, in ruefully humorous terms, his only experience of failure in connection with the tuberculin test. "I had a good bull calf, and I thought 
he was worth doing well, so I kept him in and fed him through the summer, putting him to his dam night and morning. No more of that for me."

Since 1888 Scotch bulls have been used at Swinnie. The first of them was Marquis $(56,147)$, bought as a calf at the sale of the late Mr Bruce's herd, Burnside. At that time $\mathrm{Mr}$ Davidson had the management of the herd owned by the late Miss Milne of Otterburn. Marquis was bought for Otterburn, and Mr Davidson had the use of him. He proved a front-rank sire. Then followed Velvet $(68,029)$, Doubtful Duke (83,313), Violet's Pride (93,761), Silver Arrow $(97,136)$, Stoneytown Baron (128,347), Bellatrix $(11,895)$, Saracen $(133,429)$, and Millom Count $(138,924)$. In his use of bulls Mr Davidson has been handicapped to some extent. His bulls run out with the dairy cows, and the women can hardly be persuaded to go to the fields if a two-year-old or more mature bull is grazing. Mr Davidson, who was born and bred on Swinnie, has many interesting reminiscences in connection with Border-district Shorthorn breeding from Mertoun to Faldonside, and from Dryhope to Baillieknowe, Legars, and Otterburn.

\section{Terrona.}

Terrona, on the Langholm section of the Buccleuch property, has been held by the Paterson family for fully one hundred years. The grandfather of the present tenant entered the farm in 1818 , and died in 1876. A man of great energy and resourcefulness, he 
reclaimed most of the farm from rough grazing, removed boulders, carted hundreds of tons of useful soil on to the bare portions, banked the river Esk where it was wont to spread out in times of spate, and practically built the farmhouse and steading. Most of that work was finished before 1841. The late Mr John Welsh Johnstone Paterson, son of the great improver, was born at Terrona, and he died there in December 1904. "J. W. J.," as he was wont to be termed by many of his familiars, had probably no equal in the South of Scotland or over the Border as a judge of a hunting horse. For a long time he was Master of the Eskdale Hounds, and his many services to sport and agriculture were handsomely recognised towards the close of his career in a presentation portrait. A man of middle height and very powerfully built, his strong, mobile, well-tanned countenance, with nothing but its short side-whiskers to hide the play of expression, proclaimed offhand an open-air life in sun, wind, and shower. At a show luncheon he was all geniality, but when he had to respond for "The Judges," he wasted no time. He said something in particular, and said it very well in the homeliest of terms, then sat down.

Mr Paterson founded his herd of Shorthorns about 1862 with district families, and he held very much to the Border strains until 1893-94, when the Cruickshank cattle were steadily coming into prominence. His more prominent bulls were Stannington $(60,012)$, Major Windsor $(34,739)$, British Beau $(58,560)$, and Carpet Knight $(85,529)$. Over twenty years ago his 
principal families of cattle were the Peach Blossom and Butterfly Princess, of Bates blood; the Heatherwick Fairy and Mayflower; the Jenny Lind; the Countess of Mason descent; and the Strowan Cowslip.

The best animals which he acquired in course of 1893-94 were Goldie 36th, bred at Uppermill by $\mathrm{Mr}$ Wm. S. Marr, and a Broadhooks, bred by Lord Lovat. To those families the present tenant has added representatives of the Lady Dorothy and Augusta lines of breeding from the Messrs Hughes, the well-known exporters. Mr James John Paterson took up the tenancy of Terrona at the end of 1904 after the death of his father. At the outbreak of the great war the young tenant reduced the herd to an easily worked total, and then joined His Majesty's forces. With twelve cows of the Goldie, Broadhooks, Augusta, and Lady Dorothy families he is now once more building up a fine herd. Among the sires used in recent years have been Frayne Courier $(108,657)$, Perfect Motion (112,780), a blood-red Broadhooks, Ace of Trumps $(129,015)$, and Fairlawne Guardsman $(136,450)$, now in the herd, and by Collynie Knight Victor $(119,550)$, out of Rosetta 25 th by Sterling Character $(97,289)$. Fairlawne Guardsman is proving a most impressive sire. A Goldie heifer calf by him was sold for 310 gs. at the Penrith October sale of 1918.

Terrona is well up in the Borderland hill country. Charming in summer with its river-side haughs, ascending expanses, and outlooks to softly tinted uplands, the homestead and fields are open to dour 
winter storms and the keen blasts of spring. Cattle bred on the farm thrive remarkably well, however, and they improve rapidly when removed to sheltered low grounds.

\section{The Grange.}

Within the last two years Mr James Piper has turned from strenuous city business to landowning and Shorthorn breeding. At The Grange, just above Burntisland, he has 485 acres, while at Letham and Conland, on the western edge of Fife near Glenfarg, he holds 600 acres. The Grange, where Mr Piper has his residence, is one of the most picturesque spots overlooking the estuary of the Forth. Queerly mixed-looking, Burntisland, with its up-and-down weather-bashed frontage, crooked lanes, stiff gradients, surprise alleys, couthily genteel best buildings of wellburnt whin and freestone, right against quaint old hints of sea-rovering, and long associations with mighty hogsheads, cannie kegs, and "sundries," is less than a mile as the crow flies from The Grange. Working angle-wise, the severity of the pull is taken out of the roadway up to Mr Piper's house and homestead. Once there, the wildness of the partly timbered cliffs and scaurs at the back is evident. Still there is a form of "glen" road to an arable plateau which was a separate holding at one time. In all, the arable land extends to about 310 acres, of which 90 acres are at the front. One field is so steep that it can only be ploughed downhill. There 
are three distinct geologic formations-trap, mainly in the cliffs, white freestone, and limestone. Some shale is also to be found. Part of the soil is strong and sticky, but the remainder is mostly very useful loam. Over the hill the land is a comparatively free loam working down to broken trap.

In laying the foundations of his herd Mr Piper has eased and shortened the way to success by selecting the very best and by putting the stock in charge of an experienced and enthusiastic herdsman. He bought his first Shorthorns in 1918, his start being with a Pauline and a Buttercup from Millhills, both being by Cupbearer of Collynie (114,960). He then added a Kilblean Beauty by Pearlcaster $(132,650)$ from Lawhill, a Brawith Bud by Collynie Cruickshank $(105,068)$ from Duchlage, and a Broadhooks by Rosehaugh $(127,823)$ from Arngask. Returning to Millhills, he took a Law Graceful by Cupbearer of Collynie and a Waterloo by Collynie Bright Star (130,287). The Graceful had been first at the Strathearn Show, and in Mr Piper's possession she won at Kinross.

Mr Piper had admired a Clipper and a Rosebud at Lawhill, and he bought them on a second visit. The Clipper was a very fine one by Cupbearer of Collynie, while the Rosebud was one of the best bred of her line, her sire being Edward of Millhills (98,729). With the Rosebud he took her heifer calf by Goldfinder. At the same time he acquired from $\mathrm{Mr}$ W. A. Dron a Mysie by Cupbearer of Collynie, out of Lady Betty, one of the best cows in the herd, and a Clipper 
by Gloaming Star $(136,732)$, out of Newton Charity. A pretty Miss Ramsden by the Millhills Cupbearer was bought about the same period from Mr A. M. Reid, Currochs, Crieff. At the Aberdeen October sale of last year he secured a couple of lovely Augusta heifer calves by Collynie Golden Star $(130,289)$ from Mr Wylie Hill's group. These were Augusta 17th, 700 gs., and Augusta 19th, 600 gs. A beautiful Lavender, bought at a very high price from Mr John Gill, Stainton, finished Mr Piper's purchases of females for 1919. This heifer is by Ambassador $(134,612)$, the Birmingham champion of 1917. As a form of "luckpenny" he had a Butterfly heifer calf from Lawhill.

A favourite young bull with many at Mr Duthie's sale in October 1919 was the red Collynie Prince President by Knight of Collynie (112,229), out of the first-class Princess Royal cow Collynie Princess 17 th by Danesfield Storm King $(94,827)$. With Nonpareil Courtier, Scottish Archer, and William of Orange in the next three crosses this representative of a great family had some strong bidders, but $\mathrm{Mr}$ Piper emerged owner at 2900 gs. Prince President has grown well and kept his shapes.

With characteristic thoroughness $\mathrm{Mr}$ Piper has built a first-class modernly planned steading at The Grange. The old buildings were quite unsuitable for the housing of a valuable herd. Electric lighting and threshing by electric power will soon be at command. With regard to herd numbers, his intention meanwhile is to work up to a breeding total of 
about 30 cows. For The Grange alone that number might be put as the limit, but Mr Piper has always his Glenfarg district farms to fall back upon for summering the young female stock, and even for wintering the non-calving heifers.

\section{Throsk.}

Throsk farm, a few miles down the river-side from Stirling, had an extent of nearly 500 acres until 1918 , when 240 acres were taken off it by the Admiralty. A representative carse-land holding of deep, substantial clay loam, it was noted for a long time in connection with the growing of timothy hay. Except for its fine bank of old grass sloping down to the side of the Forth, the farm is not quite a stockbreeder's ideal, as most of the soil is more adapted for cropping than for use as a grazing range. Still it is healthy, and cattle do well on its rich turf. Mr Wm. Finlayson, the highly esteemed tenant, was induced to try Shorthorn-breeding over twenty years ago. He made an easy and remarkably fortunate purchase in 1898. An admirer of the Earl of Rosebery bought Duchess of Dalmeny, a red Broadhooks, at the Earl's sale, and Mr Finlayson acquired the cow shortly afterwards. Sired by Strowan Marquis $(63,417)$, she bred at Throsk the roans Duchess Broadhooks and Princess Broadhooks, both by the roan Dunglass Lady Anne bull Carlo $(76,304)$ of the late Mr Wm. Alexander's breeding, and a first-prize winner at Messrs Speedie Brothers', Stirling show and 
sale. Those two females proved prolific and first-class breeders. In course of a decade Mr Finlayson bred many greatly admired animals by the use of front-rank bulls. Duchess Broadhooks 2nd was dam of Throsk Broadhooks, the second-prize bull in the older class at Perth in 1909, and the top-priced animal of the sale. $\mathrm{He}$ was taken by $\mathrm{Mr}$ Donald Maclennan at 550 gs. for the Argentine. Mr Finlayson next tried a Wild Eyes from Mr J. M. Hall of Middlefield House, Cumberland, a Fancy from Messrs Lumsden \& MacKenzie, and Bright Gem 2nd, a pretty cow from the Duke of Buccleuch, and tracing back to a Wood foundation. These and their produce were all sold off in course of a few years.

In $1918 \mathrm{Mr}$ Finlayson sold the larger portion of his herd at Aberdeen, as the much-reduced farm was thrown out of its ordinary working arrangements at that time. A Rosemary family was then cleared out. The first of that strain at Throsk was the Tilbouriesbred Rosemary 119th, bought at Bletchley. She was a very handsome roan by Mr John Young's favourite Duthie bull Bonnie Scotland $(82,915)$. Her daughter, Rosemary 120th by Doune Bondsman $(115,098)$, inherited her mother's good looks. Mr Finlayson has done well with the Elizas. His first of this fine old family, so much associated with Pirriesmill, was Flora of Phingask, a white by Broadhooks Mint (98,221), dam by the Collynie Royal Charter $(84,585)$. She bred a number of good bulls, and two of her daughters, Eliza 2nd and Eliza 3rd, both whites by Boquhan Guardsman $(114,407)$, are now on the farm. He 
has not been fortunate with his Princess Royal and Augusta purchases.

Of the first noted, the start was with the roan Princess Royal B. 3, bred by Mr H. M. S. Mackay, Burgie Lodge. A daughter of that cow produced a grand red roan bull calf by Boquhan Guardsman, but the family line then became extinct at Throsk. Augusta 81st, a white heifer from Cairngall, and with the very finest Collynie topcrosses, promised well, but she stopped breeding after producing one bull calf. With the Marigold family Mr Finlayson has been more successful. Marigold Maud 4th, a great framed yet feminine-looking old roan cow, was acquired from Mr A. M. Gregory as a calf. Her sire was Red Clipper $(96,648)$, and her dam was by the good-looking prize-winner Diamond Gift $(94,833)$. One of her sons won two or three championships and other awards for Miss Staples. She had a very good heifer calf in 1918. On the female side the herd now consists of nine Broadhooks, two Elizas, two Marigolds, and a Clipper, the last noted being a sweet red heifer bred at Montrave and by Duchlage Secret $(125,262)$.

The first bull used by Mr Finlayson was Holywood $(95,502)$, a dark roan of the Countess family, bred by Mr Hutchison, Cairngall, and by Baron Lavender $(85,273)$, the highest-priced Duthie calf of his year. Then came the Perth third-prize bull Doune Diamond 2nd $(105,288)$ by Diamond Earl $(98,591)$ out of Lady Maud, a Meg Merrilies cow. Another son of Diamond Earl followed in the dark roan Doune Raider 
$(108,419)$. This was an excellent breeder. His dam was Ballechin Rachel by Marquis $(84,061)$. The Rachel bull was succeeded by Boquhan Guardsman $(114,407)$, a red roan of the Dairymaid family by Collynie Cupbearer $(105,069)$. About the same time some use was made of the red Broadhooks bull Doune Bondsman $(115,098)$. The present stock bull is the handsome red Collynie Golden Boy $(130,288)$ by Max of Cluny, out of a great Bessie cow, which won first prize at Perth as a yearling heifer. $\mathrm{He}$ is proving an excellent breeder.

Mr Finlayson may be able, in course of time, to work up to his pre-war standard in Shorthorns. So far as they go, he has now a grand collection of females, his Broadhooks cows especially being worthy of their farnous family when seen at its best.

\section{Tulliallan.}

After a long term of strenuous work in South Africa, Sir James Sivewright, K.C.M.G., had all too short a period of the life which he loved in his heart of hearts. Moving about at charming Tulliallan, he was peculiarly in his element. By the lower reaches of the broadening Forth he could hear the cries of the water-birds on the shimmering oozy mud as the tide lapped backward to the ocean. Quaint Kincardineon-Forth, with its suggestions of old-worldliness and thrift, its more than hints of the higgledy-piggledy, and its homely matter-of-factness, was just at hand by the scarce-moving river. A little aloft were the 
mixed woodlands with their alleys and sinuous footways, along which a stranger could get delightedly lost, and well beyond there were the background and half-flanking of hill and mountain country from the Ochils to Ben Ledi and around by Ben Venue to Ben Lomond. Best of all in a certain sense, the home farm, with its roomy comfortable steading, gentle slopes, and not unduly large fields, was easily reached, and there Sir James had pure delights in talks with the ever perfectly natural George Michie, the herdsman, to whom the cattle were never mere animals but "weel-deèn" (well-doing) subjects or the reverse. "Cows all settled, George?" "Weel, Sir James, I'm no maistly sure o' them a'. I wid pardon that heifer there, the cratur; she's near sookit to daith be a muckle bul-calf. But look at that jaud there wi' a' her abeelity an' just sookin' a bit heiferie thingie. Dagond I'm no sure o' her yet." The exposition of George's system of bovine morals was more to Sir James than was the clotted cream to the wild men in Lorna Doone's country. To his favourite calves, which were not fully appreciated by certain judges, George could be confidential and consolatory. "Never ye mind," he would say to some junior, "ye'll be a gey bul some day, my mannie, whaever leeves to see't."

It was in 1905 that $\mathrm{Mr}$ John C. Wilson, the estate agent, began to select foundation stock for the Tulliallan herd. His purchases were the noted Eliza show cow Ella from Mr James M'William, then of Stoney. town; a Brawith Bud and a Nonpareil from Mr 
Petrie Hay Keith; a Broadhooks from Throsk; a Lovely and a Jilt from Tilbouries; a Goldie from Corston ; a Kilblean Beauty from Dunglass ; a Clara and a Lauretta from Mains of Murthly; an Averne, an Emmeline, and a Carnation from Ballechin; a Miss Ramsden from Bruceland; a Julia or Dairymaid from Pirriesmill ; a Regina from Collynie; and a Waterloo from Beaufort. The latest addition is Augusta Maisie, a beautiful red yearling 520 -gs. purchase from $\mathrm{Mr} \mathrm{A}$. J. Marshall. The Elizas so much associated with Pirriesmill have, on the whole, proved the most successful in the herd, and they now lead in numbers. The Carnation family produced the remarkably handsome roan bull King George- "Ca'ed maistly efter His Majesty," as Michie confided to some one. King George took first in the Perth older class of 1913, and was sold at 720 gs., the highest price realised at auction in Scotland that year. His sire was the red Saphock-bred Broadhooks Earl $(101,655)$. Bulls from the herd have always done well at the Perth spring sales and have passed into well-known herds at home and abroad. Young female animals have been mostly disposed of privately. At the Aberdeen October sale of 1918 a few heifer calves were offered, and a Goldie drew 450 gs., the average for four being $£ 273$.

The stock bulls have been mainly from Collynie, Uppermill, Saphock, Rothiebrisbane, and Cromleybank. Mr Wilson made a specially fortunate purchase in the grand red bull Lancaster Royal $(109,108)$, bred by the late Mr John Marr and closely related to the noted Collynie stock bull Knight of Lancaster, 
for which Mr Duthie paid 1000 gs. at the Uppermill dispersions of 1915. Sired by Royal Leader (103,727), Lancaster Royal was a bull of high-class breed character, great scale, fine quality, and perfect temper. The cows by him are not only good to look at as symmetrical, short-legged, Scotch Shorthorns; they are excellent milkers and true breeders. The Collyniebred white Merry Victor $(116,563)$, acquired as a twoyear-old at Colonel Munro's sale in 1914, has proved highly successful, especially when mated with the Lancaster Royal cows and heifers. $\mathrm{He}$ is a big handsome-looking bull by Merry Stamp $(99,629)$, out of Vine 2nd, by the 1000 gs. Perth first-prize Achilles $(93,962)$. At the Perth spring sales of 1919 a very fine young bull, with specially good hindquarters, was acquired at 750 gs. in Harviestoun Norseman, a roan Nonpareil bred by Mr J. E. Kerr and by Sanquhar Grand Gallant (133,421).

In numbers the Tulliallan herd usually ranges from 70 to 80 head. At the present time it is the largest in the county of Fife. Occupying rising ground on the northern bank of the Forth, the farm overlooks historic Dunmore across the water, and a few miles farther away to the east is Keavil, where Tom Easton saw visions and dreamed dreams, in which Heir of Englishman was central figure. (See Appendix.)

\section{WESTSIDE.}

"Born Stockmen." That is the general and perfectly just summing up on the Messrs Cameron, 
Westside. The late $\mathrm{Mr}$ Archibald Cameron, a man of remarkable natural abilities, left his native Perthshire for the Black Isle of Ross in 1872. There he leased the farm of Artafallie. In 1882 he took Killen, and with the assistance of his clever sons, Messrs Donald, John, and Archibald Cameron, he soon made the farm famous for Shorthorn cattle and Border Leicester sheep. Beaufort, then managed by a master judge, Mr Lawson, was the special attraction in Shorthorns. From that stronghold the Messrs Cameron acquired their first Broadhooks and Dairymaids. A Lady Sarah was added from Major Cradock; a grand family of Flowers-short pedigreed, but milky and noble - looking-came from Yorkshire; the Revelry line of Dunmore note was added; and the Lady Waterloo family was a good acquisition from Fettes, where the late $\mathrm{Mr}$ Duncan Cameron, another of $\mathrm{Mr}$ Archibald Cameron's sons, had a fine herd. $\mathrm{Mr}$ Duncan Cameron was the first to take a Waterloo into Ross-shire, his original purchase being Lady Waterloo 32nd, bred by Mr Ecroyd, Armathwaite.

In 1900 the Messrs Cameron quitted Killen for Westside, on the Earl of Dalhousie's property near Brechin, and there the herd and flock have been kept going, and always with improvements in view. Westside, which extends to 460 acres, has about 100 acres of thin, half-moory, scorching land, and the main part of the farm otherwise is a friable loam on a gravelly subsoil. On the whole, it takes best with a showery season. Buildings are ample and good. After an uncommonly active, helpful life, the old 
gentleman died at Westside in October 1906. He was in his ninety-fifth year. Since 1900, high-class additions have been made to the herd on the female side. Clipper Keepsake, a beautiful white of the Cinderella line of Clippers bred at Windsor, and by Crystal Prince, dam by Wilkins Micawber $(56,768)$, was a fortunate selection. Three cows descended from her are now in the herd. Clipper Keepsake 4th was dam of the very pretty white heifer calf for which $\mathrm{Mr}$ J. Ernest Kerr paid 330 gs. at the Aberdeen October sale of 1918. A very fine family of Bellonas, now strongly represented at Westside, had their start from Sir Hugh Smiley's herd. The first Butterfly came from Balnakyle, and another of the family was selected from Boquhan, the latter being a lovely dark roan heifer calf by Collynie King Royal (114,768), out of a handsome cow by Proud Monarch $(92,961)$. In 1917 an Orange Blossom by Royal Guard $(127,907)$, out of a cow by the noted Strowan $(107,206)$, was acquired from West Fingask. Notable purchases in 1918 were a yearling in-calf Secret at the Cullisse dispersion sale, and a stylish red Augusta heifer calf from Mrs Smith of Pittodrie House. The latter calf, which cost 400 gs., was by Collynie Masterstroke $(135,826)$, from Augusta Queen by Collynie King Royal.

During the Messrs Cameron's later years at Killen and their earlier stages at Westside, Broadhooks blood was very strongly blended with the herd, and the Duke of Beaufort element in the great Lovat family was not easily held in subjection where colours 
were concerned. The Shorthorns of those periods were beautiful cattle with flat horns, prominent eyes, and high-class countenances as a rule, but the Duke's gaudy markings tended to assert themselves. The existing herd, however, is to a large extent a new one. The additional families to which reference has been made, and the fresh crosses of Cruickshank blood, have instituted a new departure, and in that movement rich-coloured handsome cows of the Broadhooks family take a prominent place. The Waterloos, of which there are three branches, look striking, and the Clippers have more substance than was wont to be associated with animals of that line. The Flowers hold to their good looks, while distinction in character is still seen also in the remarkable Lady Sarah family.

Reference has been made to the Broadhooks influence. Between 1877 and 1885 four Lovat bulls of the dominating family were used by the Messrs Cameron at Killen. These were King of Kessock $(38,495)$ by Bachelor of Arts, out of Broadhooks 10 th by Champion of England; Belladrum $(42,777)$ by Duke of Beaufort $(38,122)$, out of Broadhooks 10th ; Baronet $(44,345)$, a full brother to Belladrum; and Albion $(47,334)$, also by Duke of Beaufort, out of a daughter of Broodhooks 10th. A successful outcross was secured in 1898 through $\mathrm{Mr}$ Willingham Fowler's first-prize-winning bull Welcome Guest $(75,875)$, which was out of the famous breeder Zeal 36th, the dam of the Doncaster Royal first-prize winner and reserve champion, Eryholme Prince 35th $(60,784)$.

The Zeal line of blood, always favoured by $\mathrm{Mr}$ 
Donald Cameron, was further worked into the herd by the use of the home-bred Star of Edzell $(82,388)$, Welcome Stamp $(78,135)$, Martial Hero $(79,383)$, and other bulls. Three of the best bulls of the Cruickshank order used during the Messrs Cameron's first ten years at Westside were the red roan Leo, a Lancaster of Mr N., Reid's breeding and by Lochnagar $(74,854)$; the home-bred dark roan Ury Archer $(84,945)$ by Archer's Heir $(76,037)$, grandam by Scottish Archer $(59,893)$; and the Phingask red Golden Mere $(102,373)$ by Golden Mascot $(95,330)$. The principal stock bull at the present time is one of the most beautifully-proportioned and best-bred sires ever used by the Messrs Cameron. This is the red Postmaster $(144,482)$, bred by Captain Fletcher and by Burgomaster $(124,176)$, out of Pauline 11th by Newton Crystal $(92,658)$. Postmaster cost 650 gs. at Perth.

Regular management at Westside falls upon Messrs John and Archibald Cameron. Mr Donald Cameron, who is actively engaged in business, finds intellectual stimulus and recreative scope for experiments at the Forfarshire farm.

\section{Whittingehame Mains.}

Mr Wm. T. Malcolm, formerly tenant of Dunmore, Stirlingshire, has had lifelong experience of the Shorthorn breed. His father, the late Mr John Malcolm, died at Langton Farm, near Falkirk, in 1861. Mr Wm. T. Malcolm's mother, who carried on the farm, made her first purchase of a Shorthorn 
bull in 1865. That was Sir Walter, an English-bred white. Mrs Malcolm showed enterprise all the time she held Langton, but from the late sixties on to 1878, when she gave up farming, she was guided by the judgment of her son, Mr Wm. T. Malcolm. It was in 1879 that he took a lease of the worldfamous Dunmore. Fittingly, in a sense, his first bull at the great homestead was the Bates Marquis of Worcester, bred by the Earl of Dunmore. One of the best bulls ever used by Mr Malcolm was The Abbot $(60,229)$, a beautiful roan of the Goldie family, bred by Mr James M'William when at Stoneytown, and by the Collynie Democrat $(55,560)$. He won nine first prizes in succession, six silver cups, and took second at the Highland. Golden Horn, a handsome white, also bred by $\mathrm{Mr} \mathrm{M}^{\circ} \mathrm{W}$ illiam and by Democrat, was used to some extent along with The Abbot. Then came the massive roan Clarence $(66,845)$, bred at Westerton by $\mathrm{Mr}$ James Durno, now at Rothiebrisbane, and of the noted Myrtle family.

During the twenty to twenty-five years succeeding, many fine bulls were used at Dunmore, and most of them were exported. Master Archer $(70,962)$ and Vain Beau $(71,854)$ came from Collynie, and the former was sold to the Earl of Powis, in whose herd he bred remarkably well. Fitz Barnet of Booth blood, and bred by $\mathrm{Mr}$ J. J. Moubray, was an experiment. A fine show bull and splendid breeder followed in Marksman $(70,945)$, bred at Pirriesmill, but acquired as a three-year-old from Mr John Granger, Pitcur. Marksman, which was of the Meadow Queen family, now so successful in $\mathrm{Mr}$ Duthie Webster's herd, 
helped much in putting a showy finish on $\mathrm{Mr}$ Granger's Groats. Exported to the Argentine, he proved useful there for a good many seasons. Victorious $(73,822)$ and The Leader $(66,428)$ from Collynie, the latter by Gravesend, and Ajax of Cluny $(76,002)$, a grand-iooking red, were well known rather later. Ajax took first and the reserve for the championship at Belfast. Gilderoy, a blocky white Bellona, bred at Jackstown, and out of the same dam as the champion Choice Goods; Count Fragrant (74,293), bred by $\mathrm{Mr}$ Duthie; Defender $(63,865)$, bred by Mr Jas. M'William; and Ballachraggan Admiral $(87,842)$, were among the succeeding notables at Dunmore. Admiral was one of the best bulls ever used by Mr Malcolm. He won at the county shows, and took second at the Peebles Highland, and was sold in the Argentine for $£ 2000$.

A few years later the most famous bull was the roan Bapton Champion, which had a transfer from Collynie. Merranio $(99,619)$, a very fine Missie bull of Mr Potter's breeding, and the Royal Norwich winner Gunthorpe Beau (108,822), attracted much attention at Dunmore. The last of Mr Malcolm's prominent show bulls before he quitted the Stirlingshire farm was the red roan Saphock-bred Royal Marksman $(117,494)$, the champion at Edinburgh and Aberdeen, and second-prize winner at Manchester Royal. In $1916 \mathrm{Mr}$ Malcolm quitted Dunmore in favour of his son, Mr Wm. M. Malcolm, and he took a lease of Whittingehame Mains. His principal stock bulls in East Lothian have been of Mr Duthie's breeding. Collynie Silver Knight, a beautiful white of the 
Clara line by Knight of Collynie, from a Danesfield Storm King cow, and Collynie Campaigner, a Clipper by Knight of Collynie, have proved valuable breeders.

The first female animal of any consequence which Mr Malcolm bought after entering Dunmore was a Golden Drop, bred by the late Mr Stott in Kincardineshire, and by Achilles (40,951). This member of a family much esteemed by Mr Wm. Duthie won the Challenge Cup at Stirling as a three-year-old. Her daughter, Wave Drop by Wave King $(48,916)$, afterwards won the Cup as a two-year-old, and her granddaughter, Rain Drop by The Abbot, finally secured the trophy. Rain Drop was probably the best of her line at Dunmore. She was twice third at the Highland, and was sold for exportation. The next female acquired was Rolla, bred by $\mathrm{Mr}$ M'Kessock in the North. As a yearling she led at the Highland. Hathaway 5th, another fine white, was bought at $\mathrm{Mr}$ Duthie's sale in 1902. She was by Scottish Fancy, her dam being by Master of the Ceremonies. At the Legars dispersion sale Mr Malcolm bought Lowland Beauty and Dewdrop. The former produced Lowland Dream, a Highland Society third-prize winner, and the latter bred Invincible, an Edinburgh winner.

Pretty heifer calves were secured at the Stoneytown sale in 1905. These were Roan Gem by Pride of Avon (86,878), and Lady Duff by Gold Bank $(86,063)$. Roan Gem's first calf in Stirlingshire was Dunmore Garnet, which, after taking many prizes, was sold for U.S.A. Her second calf was Dunmore Garland, which as a two-year-old led at the Dumfries Highland, and wherever shown. Unfortunately 
she was lost at the calving. Members of the Broadhooks and Goldie family-two of each-were added to the herd in 1909-10. Goldie 31st, bred by Messrs Meiklem in Fifeshire, was sold to the Rt. Hon. A. J. Balfour, and her daughter, the beautiful red Goldie 32nd, won first as a cow at Edinburgh for Mr Balfour, and was the highest-priced animal at the Whittingehame dispersion, as already noted in connection with the Naemoor herd. Members of the Miss Ramsden, Princess Royal, Clipper, Secret, Augusta, Rosewood, Fairy Queen, and Lavender family have been added to the herd during the last few years. These, and the Goldies, are the principal families now in the herd. With the five-year-old Princess Royal Beauty the Whittingehame Mains tenant won at the Royal and Highland Shows of 1919, the female championship also falling to him at the latter.

For a good many years Mr Malcolm was Scottish adviser to the late Mr Philo L. Mills of Ruddington Hall, and Dunmore was then more of a temporary home for well-bred lots of animals mainly intended for export than a steady breeding centre. After the death of Mr Mills, Mr Malcolm took more and more to regular herd building. For a breeding herd Dunmore soil, as a whole, is too strong and rich if anything, and the steading is over-spacious in a sense. In East Lothian, Mr Malcolm has plenty of scope in a drier climate and on sharper soil than that to which he had been long accustomed in Stirlingshire. 


\section{APPENDIX.}

THE Tulliallan herd, which was dispersed on 1st September, had a general average of $£ 363,5 \mathrm{~s}$. $1 \mathrm{~d}$. for 68 head. Bull calves were retained for the spring sales. The class averages were: 32 cows, $£ 386,7$ s. 4 d.; 6 two-year-old heifers, $£ 458,10$ s. ; 10 one-year-old heifers, $£ 374,17$ s. ; 18 heifer calves, $£ 236,5$ s.; 2 stock bulls, $£ 792,15$ s. For the two-year-old Norseman of Harviestoun $(150,829)$, Mr R. Wylie Hill paid 1350 gs., the top price of the sale. Prominent buyers of female animals were the agent of the Prince of Wales, Mr James Piper, Mr J. J. Moubray, Mr Wm. Niven, Mr Jas. Gardiner, M.P., Captain Fletcher, and Mr James Butters.

Boquhan dispersion sale was held on 16 th October. It resulted in a general average of $£ 346,13 \mathrm{~s}$. $3 \mathrm{~d}$. for 89 animals. Separate averages were: 35 cows, $£ 356,3 \mathrm{~s}$. 2 d.; 6 two-year-old heifers, $\mathfrak{f} 488$, 5s.; 10 one-year-old heifers, $£ 470,8$ s.; 11 bull calves, $£ 117,3$ s. 4d.; 22 heifer calves, $£ 264,15$ s. 9 d.; 5 bulls, $£ 725$, $19 \mathrm{~s} .5 \mathrm{~d}$. Here again the agent for the Prince of Wales was a buyer. He paid 3000 gs., the highest price of the sale, for the noted dark-roan stock bull Collynie Master Lavender (141,710), and $1250 \mathrm{gs}$. for the beautiful Queen of Rothes cow, Boquhan Violet. Unfortunately both animals were destroyed by fire while on railway transit to the south. Mr Wm. Duthie paid 1550 gs., the leading price in the female section, for Boquhan Rosebud 3rd. $\mathrm{Mr}$ James Piper took a very fine Princess Royal heifer at 1100 gs., and a good many Scottish Central breeders were prominent buyers.

At Mr Wm. Duthie's sale, the dark roan Estelle calf Collynie Masterpiece, by Max of Cluny $(112,487)$, was taken out for Mrs Stewart of Millhills at 2600 gs.; the Keir agent paid 1900 gs. for the red Secret Collynie Standard by Masterstroke (126,820); Mr W. T. Malcolm took the red Clipper Collynie Captain by Masterstroke at 820 gs.; and Mr James Gardiner, M.P., paid 640 gs. for the red Bessie Collynie Vice-President by Cudham President $(147,292)$. On the same day at Uppermill Mr W. A. Dron secured the dark roan Beauty calf Scotch Baronet by Collynie Baronet 
$(135,812)$ at 1000 gs. ; and Mr Matthew Marshall paid 850 gs. for the dark roan Brawith Bud Knight Commander by Collynie Baronet. At Mr F. L. Wallace's sale Mr J. Ernest Kerr paid 3100 gs. for the dark-red roan Orange Blossom Balcairn Oracle by Collynie Golden Sun $(135,820)$; the Earl of Moray's agent took the red Goldie Balcairn Guardsman by Collynie Golden Sun at 2700 gs., and $\mathrm{Mr}$ Marshall paid 1100 gs. and 1200 gs. for roan Wimple and Princess Royal calves by Earl of Kingston (120,041).

The leading price at the Aberdeen joint sale was paid by Mrs Stewart. She secured at 1800 gs. Mr J. J. Moubray's beautiful red yearling heifer Naemoor Lavender by Garbity Field Marshal $(142,541)$.

Mr Moubray's remarkably successful stock bull Garbity Field Marshal $(142,641)$ is of the Mabel branch of the old Shethin Mysio family, and his sire is the noted Edgcote Flatterer (125,374), which left many high-class animals in the late Mr James M'William's herd. Edgcote Flatterer is by Ascott Clipper $(107,666)$, and his dam was the Missie cow Mistletoe 41 st by Golden Primrose (98,979), grandam. by Scottish Archer $(59,893)$, great-grandam by William of Orange $(50,694)$.

The now four-year-old Sanquhar Grand Courtier (139,193), which was two seasons stock bull in the Saltoun herd, and first notable as sire of D.S.O., won championship honours at the Darlington Royal for $\mathrm{Mr}$ Oliver W. Porritt, Hotchley Farm, Loughborough.

First-class herds are being formed by Messrs Paton \& Coleman, Gorthy, Methven; Mr Alexander J. M'Laren, Milrig, Kirkliston; Mr Donald M'Dougall, Dall, Killin; Mr W. M. Snadden of Coldoch, Blair Drummond; Mr A. D. Smith-Sligo of Inzievar, Fife; and $\mathrm{Mr}$ George Pitcaithly, Wester Dron, Bridge of Earn.

Lord George Kinnaird's herd, to which reference is made in the historic section, was dispersed on 3rd October 1876 under utterly wretched weather conditions. In his after-luncheon speech his lordship stated that he had been chiefly indebted at the outset to Mr Richard Booth and Mr Rose of Cotham. On the female side his principal purchases had been from Earl Spencer, Lord Huntingfield, Mr Miller of Ballumbie, Mr Grant Duff, and Mr Mark S. Stewart. The stock bull at the time of the sale was King Brian (34 308), on hire from Killerby. Among those present at the dispersal were $\mathrm{Mr}$ Thos. C. Booth of Warlaby, Mr J. B. Booth of Killerby, Mr Chandos Pole-Gell, Mr Donald Fisher, Colonel Williamson, Mr Bethune, Mr Andrew Mitchell, Mr John Outhwaite, Mr R. A. Arklay, and Mr Young, Keir. Prices for cows and heifers ranged mainly from 25 to $58 \mathrm{gs}$. Mr John Thornton was auctioneer. 


\section{N D E X.}

Abbey Mains, 146

Abbey Mains Advance Guard, 97

Abbey Mains Dictator $(134,494)$, 96

Abbotsford (69,838), 122

Abbot's Grange, 131

Abercromby, Lord, 141

Aberdona, 207

Ace of Trumps (129,015), 199, 294

Achilles (40,951), 311

Achilles (93,962), 240, 304

Activity $(73,942), 263$

Adbolton King Millicent $(107,584)$, 144

Adbolton King Tulip (129,026), 269

Adderstone Grange, 202

Admiral (123,793), 246

Admiral (56,797), 287

Agnew, Sir A., 148

Aidecamp (30,364), 272

Aigas, 100, 102, 176, 235, 284

Aikbank, 215

Ainslie, Mr, 248

Ajax of Cluny $(76,002), 310$

Alastair (78,217), 191

Albert College, 278

Albert Zenith $(101,234), 121$

Albion (47,334), 307

Aldbro, 238

Aldie, 105, 154

Aldie Armistice, 99, 283

Aldie Emblem (140,384), 178

Aldie Mac, 99

Alexander (123,848), 107

Alexander, E. M., 124, 141, 142

Alexander, John, 142

Alexander, Wm., 298

Alexandrina family, 141

Alfred the Great $(107,617), 131$
Allan, 211

Alloa, 248

Alnwick Favourite, 182

Alnwick Park, 203, 249

Ambassador $(134,614), 235,284$, 297

Anderson, A. H., 217, 218

Anderson, A. M'K., 217, 218

Anderson, D., 135, 144, 233, 244

Anderson, George, 112, 127

Anderson, P. S., 218

Anderson, $\mathrm{R}$ (Fingask Ho.), 102

Anderson, T. A., 131, 168, 231

Anderson, T. I., 219

Anderson, W., 188

Angus, Messrs, 221

Anna family (Knighthy), 112, 113

Archer, 216

Archer's Heir (76,037), 308

Arclight (113,917), 258

Ardarg, 265

Ardgaith, 103

Ardlethen Colleague, 235

Argo, G., 205, 252

Armathwaite, 305

Arngask, 127, 144, 172, 219, 284, 296

Artafallie, 305

Ascott Clipper (107,666), 122, 128

Ascott Pride $(104,567), 252$

Ascott Royal (104,568), 284

Ascott Wanderer $(101,295), 260$

Athabasca, 186, 279

Athelstaneford, 212

Auchencrieve, 120

Auchnacree, 105, 147, 162, 177,!189, 256,288

Auchnacree Laird $(134,740), 110$, 197, 256 
Auchnacree Laird 2nd, 111

Auchnacree Mogul, 111

Auchnacree Rajah (134,744), 110, 111,235

Auchnacree Vizier $(129,241), 147$

Auchnacree Whyte $(118,644), 156$

Augusta family, 98, 112, 126, 127, $128,129,130,131,133,134,135$, $136,142,144,148,149,156,157$, $158,161,165,168,171,172,174$, $176,177,199,200,205,210,215$, $220,226,232,238,242,252,259$, $264,267,269,276,294,297,300$, $303,306,312$

Auldtown of Carnousie, 97, 182, 210

Averne family, 142, 143, 167, 303

Aylesby, 211, 212

Aylmer, H., 248

Bacchus of Dalmeny $(66,642), 253$

Bachelor of Arts, 307

Baillieknowe, 290

Bain Bros., 291

Baker $(62,102), 168$

Balcairn Crusader, 254

Balcairn General, 175

Balcarres, 145, 227, 273

Baldinnie, 159

Baldowrie, 106, 114-116

Baldowrie $(65,091), 168$

Balfour, Right Hon. A. J., 242, 312

Balgowan, 270

Ballachraggan, 131, 215, 218, 264

Ballachraggan Admiral $(87,842), 310$

Ballechin, 112, 142, 149, 154, 178, $185,186,191,220,221,222,231$, $237,249,268,269,272,279,301$

Ballechin Brigadier, 119

Ballechin Cardinal $(134,795), 118$, 233

Ballechin Corporal, 118

Ballechin Crown, 118

Ballechin Magnet, 119

Ballechin Major, 120

Ballechin Mutineer (134,798), 118

Ballechin Senator (118,702), 119

Ballechin Type $(85,212), 236$

Balmanno Castle, 121

Balnabeen Gipsy Lad, 262

Balnagubs, 168, 181

Balnakyle, 108, 109, 157, 269, 283, 285,306

Balnakyle Channel Stane $(107,754)$, 98
Balnakyle Regent, 202

Balthayock, 104, 109, 205, 231

Balthayock Golden Sphere, 129

Balthayock Lavender $(114,991), 147$

Balthayock Ramsden $(140,699), 129$, 290

Bandmaster (97,929), 162, 164, 278

Band Sergeant (101,336), 231

Banner Bearer (27,907), 212

Bapton Champion $(78,285), 133,135$, $194,247,310$

Bapton Diamond $(79,289), 150$

Bapton Favourite $(76,080), 152,205$, 208, 239, 263

Bapton Malcolm (134,909), 233

Bapton Manor, 182, 233

Bapton Proud Monarch (124,416), 182

Bapton Reuben (114,127), 182

Bapton Sceptre, 151

Barclay, Captain (of Ury), 106, 115, 117,271

Barnes, John, 169

Baron Bridekirk 49th $(118,816), 100$

Baron Broadhooks (101,398), 266

Baron Butt (48,309), 261

Baroness family (Strowan), 109, 126, 147

Baronet $(44,245), 307$

Baron Groat 2nd, 184

Baron Lavender $(85,273), 300$

Baron Ravensworth (7811), 214

Baron's Pride (97,986), 216

Barrelwell, 259

Barrington family, 257

Barrogill Crest (129,525), 208

Bashful Boy (85,301), 283

Bates, 145, 261, 287, 294, 309

Bearcroft Golden Crown, 132

Beattie, Jas., 229

Beaufort, 105, 113, 134, 151, 168, $169,170,229,256,264,303,305$

Beaufort Castle, 237, 238

Beaufort Count $(114,249), 246$

Beaufort Rothes General, 281

Beaufort Rothes Prince $(124,215)$, 254

Beaufort Snow King $(140,873), 258$

Beauty family (Kilblean), 147, 158, $172,174,179,191,192,214,223$, $227,255,272,285,296,303$

Beauty family (Simmers), 142

Bell, R. W., 138, 187, 226

Bella family (Heatherwick), 210

Bella Booth family, 229 
Belladrum (42,777), 307

Bellatrix (11,893), 291, 292

Bellona family, 102, 121, 133, 134, $135,160,201,219,220,277,306$, 310

Belted Knight (56,933), 272

Berkeley Castle, 171

Bessbrook (124,300), 124, 139, 179, 210

Bessie family, 156, 199, 208, 219, 223, 233, 249, 278, 301

Bessie family (Uppermill), 97, 119, $139,148,154,196,199$

Bethune, Mr, 248

Billy (3151), 271

Birdsall Briar (101,547), 283, 284

Birdsall Centaur, 145

Blair Drummond, 131

Blair, Captain T., 207-209

Blair, Thomas, 207

Blanche family, 257, 258

Blantyre Park, 266

Blebo, 248

Blencow (11,182), 211, 212

Bletchley Park, 171

Blithe family (Naemoor), 248

Blythesome family, 131, 148, 158, 233, 245

Bold Bailie $(90,943), 118$

Bolshan 2nd $(58,535), 168$

Bonnie Scotland (82,915), 299

Booth, 212, 261, 286

Booth family, 249

Booth, R., 249

Booth, T. C., 149, 248

Boquhan, 146, 220, 253, 264, 306

Boquhan Augusta Chief $(129,746)$, 210

Boquhan Augusta Prince (529,748), 265

Boquhan Champion (104,838), 223

Boquhan Guardsman (114,407), 299, $300,301,303$

Boquhan Lavender Monarch $(99,348)$, 124

Boquhan Mintmaster (119,116), 136

Boquhan Pride (111,114), 199, 232

Boquhan Proud Monarch (124,416), 132

Boquhan Royalist (129,758), 136

Boquhan Stamp (114,408), 233

Boquhan Standard Bearer (114,409), 96

Bowden, Mr, 242

Brackla Leader (129,798), 196
Brave Augustus (107,996), 119, 220

Brave Marquis (119,158), 224, 268

Brawith Bud family, 102, 121, 124, $127,128,131,136,138,142,148$, $156,157,174,176,183,191,193$, $199,200,208,216,223,224,235$, $242,264,266,268,280,296,302$

Brawith Chieftain (141,177), 169, 235

Bridegroom (82,944), 216

Bridegroom (11,203), 213

Bride's Monarch (141,193), 145

Bridgebank, 147, 148

Bridgebank Orangeman, 123, 125

Bright Boy (60,403), 138

Bright family, 142

Bright Star $(74,116), 192$

Bright Stone, 195

Brierley, C. W., 281

Brilliant (56,89l), 201, 229

Brilliant Chief $(66,741), 229$

Brilliant Star $(76,240), 120$

British Beau (58,560), 293

Broad Arrow (114,481), 139, 179

Broadhooks Champion, 151

Broadhooks Chieftain (101,301), 203

Broadhooks Diamond (124,530), 123, $150,156,157,183,189$

Broadhooks Earl (101,655), 144, 303

Broadhooks family, 96, 98, 100,102 , $105,109,113,114,119,121,122$, $127,133,135,138,139,142,144$, $148,151,152,154,157,158,161$, $165,168,170,171,174,176,178$, $180,183,187,189,190,195,196$, $215,219,224,228,231,232,234$, $235,242,252,258,259,260,264$, $265,266,268,272,276,277,278$, $284,285,294,296,298,299,305$, $306,307,312$

Broadhooks Favourite (135,441), 226

Broadhooks Mint (98,221), 299, 301

Broadhooks Victor 2 and $(101,658)$, $145,165,270$

Brora (124,553), 226

Browells (of Apperly), 201

Bruce, C. M. (Burgie), 113, 256

Bruce, George E., 272, 292

Bruce, G. A., 179

Bruce, James, 149, 272

Bruceland, 139, 167, 303

Brudenell, G., 105

Brutus, 274

Buccleuch, 209, 222 
Buccleuch, Duke of, 299

Buchanan, A. C., 256

Buckley, Mr, 159

Budge, Mr, 291

Burgie Lodge, 300

Burgomaster $(124,576), 101,278$, 308

Burnhall, 96

Burnhall Marquis $(104,935), 96$

Burnside, 292

Burnyeat, Mrs, 106, 178, 255

Bushey of Cluny $(78,507), 169$

Butchercote, 124

Buttar, D., 159

Buttar, T. A., 119, 159-162, 182, 257

Buttercup family (Strowan), 222, 232, 286, 288, 296

Butterfly family (Cruickshank), 97, $105,108,109,111,113,127,133$, $135,142,144,146,147,154,155$, $168,174,176,177,181,183,189$, $195,196,199,205,210,219,223$, $224,227,231,235,242,246,252$, $268,276,277,284,285,297,306$

Butterfly family (Towneley), 96

Butterfly Princess family, 294

Butterfly Royal $(130,032), 132,216$

Butterfly Star, 246

Butterfly Victor, 142

Butters, Jas., 234-236

Buxley Farm, 228

Bystander (119,298), 146

Cadboll, 144

Cairngall, 300

Cairnhill, 201, 220

Cairnie, 161

Cairnton, 168

Calder (late James), 100

Calder, J. J., 99-101

Calder, Messrs, 265

Caledonia, 167

Calomel family, 248

Calthorpe, Lord, 127, 246, 250

Cambus, 259

Cambushinnie, 98, 211, 214

Cameron, A. (Cookstown), 120

Cameron, A. (Strathtay), 118, 199

Cameron, A. V., 257-259

Cameron, C. M., 109

Cameron, Duncan, 305

Cameron \& Sons, 265, 304-308

Campbell, G., 135, 160, 277

Campbell, S., 242
Campsies, 133

Candahar $(78,522), 109,142,143$, 224

Cap-à-Pie, 182

Captain Edwards (8929), 213

Captain Hope $(66,778), 203$

Captain of the Guard $(58,596), 114$, $186,220,239,240,279,286$

Captain of the Mint $(94,565), 139$, 178,240

Captivator (141,429), 267, 268, 270

Carabineer $(104,976), 220$

Cardinal, 245

Carlo (76,304), 298

Carnation family (Ballechin), 96, $118,147,154,178,199,218$, 237,303

Caroline family (Baldowrie), 115, 116

Carpenter \& Ross, 216, 251, 274, 284

Carpet Knight $(85,529), 293$

Carr, F., 135

Carse of Gowrie, 116, 125

Casares, E. N., 186, 187

Casares \& Sons, 122

Cash Box (66,791), 161

Cathcart, Lady, 109, 169, 240, 272

Cazalet, W. M., 105, 127, 129, 150, $171,184,194,210,245,265$

Cerasus, 129

Challenger (108,033), 201

Champion of England $(17,526), 97$, $105,133,134,177,181,216,235$, 307

Champion of Scotland (111,261), 131, 278,279

Chanticleer (91,192), 172

Charlotte Corday family, 96, 176, $177,189,215,226,273$

Cherub 4th (33,359), 150, 186, 208

Cherry family (at Balthayock), 129

Cherry family (Manderston), 229

Chief General (124,738), 210

Chief General $(141,557), 120$

Chillingham, 249

Choice Goods, 121, 310

Chieftain $(54,344), 203$

Chieftain 2nd $(70,152), 151$

Choir Boy $(91,238), 149,150,151$, 152,200

Chorister $(76,351), 152$

Christmas Augustus (114,702), 129

Christmas Carol (105,031), 165

Clan Macdonald (78,597), 109 
Clara family, 124, 133, 135, 139, $142,148,149,195,197,199,205$, $208,215,218,223,253,258,263$, $265,266,268,269,272,276,286$, $287,289,303,311$

Clarence, 230

Clarence (66,845), 309

Claret family, 133, 134, 135, 170 , $181,183,253,278$

Claymoddie, 157

Clinton, Lord, 242

Clipper family, 97, 106, 112, 127, $128,131,133,134,135,145,148$, $149,156,162,164,165,172,174$, $180,181,182,183,184,188,195$, $197,205,206,216,219,220,223$, $227,231,238,240,252,255,264$, $267,268,269,277,285,296,300$, $306,307,311,312$

Clipper Dairyman (105,048), 258

Clipper Favourite (124,782), 245

Clipper King (108,193), 203

Clipper Monarch (135,769), 258

Clipper Record, 132

Clipper Rosemount (114,730), 265

Clipper Star $(124,786), 122,165$, 238

Cloichfoldich, 216, 242, 253, 268

Clunes, 209, 219, 269

Cluny, 285

Cluny Augustus 2nd, 99

Cluny Castle, 109

Cluny Count Florian (130,251), 106

Cluny Regent $(135,789), 143$

Cluny, Sir Augustus, 99

Clyne, W. S., 111, 208

Cock Robin, 289

Coey, James, 149

Coldstream (Kincardine), 167

Collynie, 98, 109, 110, 121, 122 , $123,126,134,138,144,151,152$, $160,161,169,170,172,182,189$, $195,196,197,201,210,220,228$, $229,233,237,238,239,240,246$, $249,251,258,262,263,264,265$, $267,272,273,277,289,299,303$, $304,309,310$

Collynie Bachelor (141,695), 224

Collynie Boy (130,285), 235

Collynie Bright Hope, 233

Collynie Bright Star (130,287), 221, 240, 247, 251, 296

Collynie Campaigner, 311

Collynie Challenger, 158

Collynie Chief $(114,765), 121$
Collynie Clarionet $(124,840), 244$, 268,273

Collynie Clipper King (135,816), 184 Collynie Commodore (105,066), 205

Collynie Conqueror $(78,609), 110$, 151

Collynie Coronet (124,841), 196

Collynie Crossbow (141,700), 224

Collynie Crown (111,334), 161

Collynie Cruickshank (105,068), 104, $145,165,193,195,220,240,268$, 296

Collynie Cupbearer $(105,069), 123$, $136,268,301$

Collynie Favourite (135,818), 162

Collynie Gold Cup, 179

Collynie Golden Baron (125,733), 120,220

Collynie Golden Boy $(130,288), 98$, $196,269,301$

Collynie Golden Dream $(119,545)$, 199

Collynie Golden Flash $(119,546), 277$

Collynie Golden Prince (111,335), 199

Collynie Golden Star $(130,289), 129$, 130, 290, 297

Collynie Gondomar (124,843), 180, 216

Collynie Grand Duke (124,844), 172 $175,181,255,285$

Collynie Grand Knight (119,549), $98,183,184,186,206,279$

Collynie King (111,336), 189, 196

Collynie King Royal (114,768), 124, 136, 146, 232, 265, 306

Collynie Knight Victor (119,550), 294

Collynie Lavender Favourite $(121,106), 245$

Collynie Lavender King (141,709), 233, 241

Collynio Mandarin (119,522), 122, 139,153

Collynie Marshal (105,071), 124, $196,224,262,273$

Collynie Master Lavender $(141,710)$, 102, 220, 228, 233

Collynie Masterstroke (135,826), 306

Collynie Matadore (111,337), 177, 183

Collynie Merry Victor (116,563), 267

Collynie Mint $(88,221), 133,135$

Collynie Nonpareil Knight, 217

Collynie Premier (124,847), 196, 278 
Collynie President (130,290), 145

Collynie Prince President, 297

Collynie Prince Royal (101,834), 202

Collynie Proud Beau, 256

Collynie Proud Duke (135,827), 236

Collynie Red Knight, 277

Collynie Regal King, 107

Collynie Royal Duke (141,715), 244, 245,246

Collynie Royal Lavender (114,770), 203, 256

Collynie Silver Knight (124,851), $147,197,311$

Collynie Silver Mint $(79,968), 260$

Collynie Storm Prince (111,339), 236

Collynie Sweepstakes $(124,852), 156$

Collynie Violet Star $(135,830), 208$, $244,285,296$

Colville, Kerr, 288

Commodore, 122

Comrie Farm, 167

Congalton, 96, 194, 283

Congalton Conqueror $(88,236), 110$, 126

Connon, W. (N. Coullie), 106

Conqueror's Heir, 187

Constance family, 234

Constitution, 199

Copland, R., 101, 168

Cornelius $(66,804), 172,183,208$

Cornelius, R., 149

Corner Stone $(68,406), 100,183,184$, $231,268,286$

Corston, 110, 119, 156, 182, 199

Costly Pearl family, 138, 139, 140

Count Broughton $(39,639), 213$

Count Crystal $(108,276), 107,273$

Countess family, 258, 273, 278, 300

Countess family (Mason), 294

Count Fascinator, 273

Count Fragrant (74,293), 310

Count Lavender $(60,545), 122$

Count Lugano (114,855), 202

Count Nicholas $(76,435), 110$

Count St Clair $(74,300), 161$

Count Scarlet, 273

County General $(111,407), 173$

Cooper, Sir R., 288

Court Favourite $(83,196), 159$

Cowslip family, 286, 294

Cradock, Major, 305

Craigie, Wm., 139, 161, 199, 219

Cranham Gerome $(119,680), 199,232$

Cran, Wm., 236

Crawford, Earl of, 111, 156
Crewe, Marquis of, 180, 194

Crieffvechter, 101, 202, 208, 214, 220, 239,267

Crieffrechter Choirmaster $(114,699)$, 176

Crocus family, 136, 181, 183, 224, $233,245,278$

Crocus family (Cluny), 232, 272, 275

Crombie, A., 168, 224, 258

Cromleybank, 134, 162, 191, 206, $241,258,266,303$

Cruickshank, A., 98, 191, 163, 227, $229,230,249,256,258,285,293$, 307,308

Cruickshank Favourite (114,941), 220

Cruickshank Favourite $(136,003)$, 120

Crusader (125,048), 202

Crusader $(130,468), 158$

Crystal Gift $(130,475), 210$

Crystal Knight $(136,009), 202$

Crystal Prince, 306

Cudham Court, 165

Cudham Fame, 208

Cudham President, 165

Cullisse, 98, 101, 127, 149, 176, 223, $226,269,306$

Cullisse Cluny, 101

Culshaw, Joe, 242

Cultoquhey, 163, 167, 270, 271

Cults, 148

Cumberland (46,144), 122, 161, 181

Cupbearer $(111,475), 253$

Cupbearer (Redgorton), 271, 274

Cupbearer of Collynie $(114,960), 101$, $119,165,177,178,193,199,202$, $219,221,232,233,240,241,270$, 284,296

Currochs, 220

Daffodil family, 222, 271, 274, 275

Dainty family, 126, 143

Dairsie Mains, 111, 149

Dairymaid family, 107, 109, 133, $134,167,171,179,215,233,237$, $258,260,264,301,303,305$

Dalcapon, 235

Dalcapon Victor $(94,820), 169$

Dalmeny, 106, 127, 128, 145, 155, $164,181,183,195,197,252,255$, 258

Dalpatrick, 237

Dalrannoch Archer $(94,822), 260$, 300 
Dalziel, Sir K., 254-257

Damside, 238, 284

Danesfield Storm King $(94,827), 195$, 197, 297, 311

Darlingfield, 202

Dasher Farm, 133

Dauntless $(54,155), 122,188,272$

Dauntless 4th $(62,369), 111$

Davidson, J., 205

Davidson, R., 138, 290-292

Day House, 142

Day Star $(55,557), 138$

Deene Park, 105

Defender $(63,865), 287,310$

Democrat $(55,560), 309$

Devonshire, Duke of, 259

Diamond Crest, 139

Diamond Duke $(111,530), 131$

Diamond Earl $(98,591), 104,114$, $145,157,180,185,187,189,205$, 300

Diamond Fancy $(94,875), 96$

Diamond Fashion $(94,877), 111$

Diamond Favourite, 224

Diamond Gift $(94,833), 300$

Diamond Jubilee, 262

Diamond Mariner (102,000), 172

Diamond Mine $(83,296), 138,189$, 197

Diamond Star $(91,478), 152$

Dickson, J. H., 214

Dictator $(65,338), 170$

Dixon, Mrs, 182

Dolphingstone, 157, 194, 225, 227

Donnybrook $(119,895), 162$

Dora family, 215

Doubtful Duke (83,313), 292

Douglas, A. M., 137-140, 210, 280

Douglas, G., 235, 242

Douglas, T. (Rhynie), 154

Doune Augustus $(142,054), 156,157$, 187,206

Doune, Baron, 187

Doune Bondsman (115,098), 98, 299, 301

Doune Bright Star, 100

Doune Brilliance, 190

Doune Diamond, 185

Doune Diamond 2nd (105,288), 260, 300

Doune Goldsmith (111,559), 260

Doune Goldstamp, 188

Doune Grand Knight $(130,657), 114$, $124,131,145,157,165,177,186$, 190,206
Doune Lodge, 101, 109, 124, 131, $142,145,182,218,222,235,251$

Doune Majestic, 100, 165, 186

Doune Marquis, 185

Doune Marshal, 186

Doune Maximum, 186

Doune Raider (108,419), 113, 300

Doune Regent, 187

Doune Reservist, 114

Doune Warlock $(125,229), 267,269$

Drakies, 151

Dream of Millions (72,378), 159

Dron, Wm., 162

Dron, W. A., 100, 114, 139, 145, $163-166,171,186,206,270$

Drummond Farm, 216

Drummond, J. (Blackruthven), 27

Drummond, J. (Cultmalundie), 31

Dryhope, 137, 138, 202, 292

Drynie, 205, 242

D.S.O., 187,190

Duchess family, 231, 243

Duchess family (Scotch), 96

Duchess of Connaught family, 97, 98, 119

Duchess of Gloster family, 128, 247

Duchlage, 238, 284

Duchlage Cruickshank, 193

Duchlage Fascinator, 193

Duchlage Marquis, 193

Duchlage Secret $(125,262), 219,300$

Dudding, H., 288

Duke of Beaufort $(38,122), 306$

Duke of Buckingham, 280

Duke of Cornwall $(80,908), 138$

Duke of Hoole, 288

Duke of Kingston 2nd (102,088), 110

Dunballoch, 105

Duncan, H. M'L., 199, 232

Duncan, R., 267

Dundee "Highland" (1843), 116

Dunglass, 124, 142, 151, 161, 167, $262,298,303$

Dunglass Brilliant $(120,003), 124$, $165,182,186,189,190,218,235$

Dunglass Chieftain $(115,188), 102$, 223,257

Dunglass Clipper (125,301), 125

Dunglass Commodore $(105,356), 143$

Dunglass Conqueror $(83,377), 283$

Dunglass Courtier, 202

Dunglass Guardsman, 268

Dunglass Marshall (111,617), 196

Dunglass Rocket, 125

Dunglass Royalist $(108,496), 186$ 
Dunmore, 188, 252, 304, 305, 309, 310

Dunmore, Earl of, 309

Dunmore Sirdar $(95,029), 152$

Duplicate, 157

Durno, Jas. (Uppermill), 182, 205

Durno, Jas. (R.), 309

Durno House, 97

Duthie, Wm., 98, 122, 128, 132, $135,139,143,154,158,160,162$, $164,165,169,170,189,190,191$, $204,205,217,228,229,249,250$, $251,256,262,263,269,281,288$, $299,300,304,310,311$

Dykes, Thos., 265-266

Earl Broadhooks $(108,560), 197$

Earl of Elgin $(91,589), 124,251$

Earl of Kingston (120,041), 153, 175

Earl of Marchmont (63,956), 281

Earl Marshal (70,343), 138, 229

East Bearford, 281, 282

Easton, 'Thos., 304

Eccles, 202

Eclipse of Collynie $(136,344), 101$, $124,145,186,190,235,251$

Economist (136,346), 101, 208

Ecroyd, Mr, 305

Edgar 2nd of Cluny (91,611), 99, $111,155,174,194,216$

Edgar 6th of Cluny (120,071), 124

Edgar of Millhills (115,256), 124

Edgcote, 196

Edgcote Crystal (136,363), 153

Edgcote Czar (120,081), 147, 232, 273,275

Edgcote Earl (136,367), 153

Edgcote Flatterer $(125,374), 218$

Edgcote Guardsman (115,269), 153

Edgcote Hero (136,371), 153, 175

Edgcote Masterpiece (115,277), 143, $183,224,251,252,253,260$

Edgcote Regalia (125,396), 107, 200

Fdgcote Sceptre $(120,101), 97$

Edgcote Shorthorn Co., 122, 124, 127, 289

Edgcote Wanderer, 285

Edgcote Watson $(111,692), 106,128$, $156,199,231$

Edward of Millhills (98,729), 296

Edwin of Ballechin (95,070), 112

Elder, Hugh, 281, 282

Elder, Thos., 281, 285

Elegance, 107

Eliza family, 98, 107, 124, 153, 158,
$226,227,250,264,269,299,300$, 302,303

Elliot, J. J. (Guelph), 241

"Elliot Mixture," 126

Elliot (of Clifton Park), 203

Elvetham, 173

Emmeline family, 104, 105, 144, 265, 303

Emmeline's Beau, 266

Emperor (3716), 115

Emperor of Oxford $(83,426), 259$

Eryholme Prince 35th $(60,784), 307$

Esmond (111,713), 180, 210, 290

Esmond's Heir, 97

Estelle family, 250

Evening Star (115,331), 106

Extraordinary $(76,640), 258$

Fairlawne Clipper King, 184

Fairlawne Forester, 153

Fairlawne Gainsborough, 210

Fairlawne Guardsman $(136,450)$, 294

Fairnington, 280

Fairy family, 294

Fairy Gold (115,355), 173

Fairy Queen family, 232, 268, 271, 275,312

Faldonside, 137, 292

Falla, 144

Fancy family, 142, 203, 240, 299

Fandango $(33,879), 211,212,213$

Fanfare family, 202

Farnley Hall, 212

Fascinator (88,569), 152, 193

Favourite Lancer $(125,520), 268$

Fenwick, Col. H. T., 177

Fenwick, Jas., 271

Fergusson, A., 167, 170

Fergusson, Donald, 166

Fettes, 258, 305

Feudal Chief $(51,251), 122$

Field Marshal, 229

Findon Mains, 97

Findon Veteran (98,621), 146

Fingask House, 156

Finlayson, J., 259, 260

Finlayson, Wm., 185, 196, 259, 270, 298, 301

First Favourite $(111,774), 154$

Fisher, D., 256, 272

Fitz Baronet, 309

Fitz Riby $(70,447), 249$

Fletcher, Captain (of Saltoun), 101, $183,190,276-280,308$ 
Fletcher, J. D., 177, 245

Flight Lieutenant, 260

Flora family (Cluny), 111

Flora family (English), 144

Flora's Favourite $(115,413), 283$

Floors Castle, 200

Florist (16,064), 213

Flower family, 305, 307

Flowery family, 128, 154

Foch, 197

Foljambe, Mr, 286

Forbes, Messrs, 235

Forth $(17,866), 211,212,213,271$

Fortune $(70,467), 109$

Fortune, G. R., 111, 112, 289

Fortuna family (Hatton), 112

Fowler, W., 307

Franciscan, 235

Fraser, Mr, 242

Frayne Courier (108,657), 294

Gainford Emperor, 122

Gainford Mandate, 139, 150

Gainford Ringleader (136,657), 131 , 157

Garbity, 138, 139, 178, 206, 273

Garbity Field Marshal (142,541), 227

Garbity New Year's Gift (136,670), 145

Garbity Primate, 218

Garbity Royal Pride (106,935), 257

Gardiner, James, M.P., 175-178

Gardiner, John, 163

Gargunnock, 130

Garue, Messrs, 249

Gartly Lancer, 253

Gartly Landseer, 106

Gartly Landsman $(125,670), 120$

Gartly Rosedale (102,309), 100

Gatty, A. A., 177

Geekie, A., 106, 114-116

Geekie, R., 106, 116, 117

Gem family, 138

Gem family (Dryhope), 280

George, 115

George 3rd (49,638), 271

Georgie family, 248

Gilderoy, 310

Gill, J., 206, 227, 228, 256, 297

Gill, Mr, 186

Gilmour, Sir John, Bart., 112, 194, 219,261

Gipsy Boy $(111,535), 285$

Glencarse, 103

Glenfarg, 103
Gloaming Star (136,732), 165, 297

Godiva Stone $(88,710), 133,195$

Gold Bank (86,063), 265, 311

Gold Cup, 194

Gold Mint (95,352), 135, 136

Golden Arrow (83,583), 126

Golden Arrow (Dron's), 164

Golden Bugler (142,637), 226

Golden Charm, 165

Golden Clipper, 264

Golden Drop family, 134, 135, 146 , $216,244,278,311$

Golden Favourite $(98,960), 154$

Golden Gift (81,168), 164, 239, 270

Golden Glory $(131,230), 132$

Golden Hero $(91,857), 188,257$

Golden Horn, 309

Golden Mark (115,607), 201

Golden Mascot $(95,330)$, 208, 308

Golden Mere (102,373), 308

Golden Primrose $(98,979), 102,162$, 240

Golden Prince (95,334), 139

Golden Prospect $(\$ 1,181), 123$

Golden Sittyton (105,643), 156, 220, 278

Golden Star, 224, 244

Golden Sunlight $(111,936), 165$

Golden Treasure $(95,346), 255$

Golden Victor (91,978), 112

Goldfinder (11,938), 231

Goldie family, $106,124,125,139$, $142,145,146,147,148,156,159$, $164,173,174,175,176,177,188$, $195,197,199,205,210,219,222$, $238,252,294,309$

Goldsmith, 244

Goldspur (64,107), 109

Gondolier $(52,956), 150$

Godomar (95,359), 259

Gordon, A. M., 251

Gordon, Col. A. T., 135, 152, 162 , $199,233,245,255,258,273,276$

Gordon Castle, 113

Gordon, J., 149, 177, 223, 268

Gorthy, 119

Gosford House, 225

Graceful family, 112, 147, 195, 210, $238,241,255,266,272,291,296$

Graham, H., 130

Graham, R., 209-210

Graham, Maxtone, 163, 167, 270, 275

Graham, Thos. (Lord Lynedoch), 270

Grahamslaw, 137 
Grahamslaw family, 229

Grand Champion (120,527), 199, 273, 277

Granger, John, 309, 310

Grant, G. R., 105, 108, 113, 147, $189,199,208,235,258$

Gravesend $(46,461), 122,161,194$, 228,310

Greenlees, 281

Gregory, A. M., 145, 300

Greig, G. C., 130

Grey, John, 115

Grey, J. S., 178

Grey Friar $(46,466), 271$

Grieve, J., 179

Grieve, John, 140

Grimston, Sir Chas., 249

Groam Duke $(65,623), 168$

Groat family, 98, 109, 110, 156, 211, $214,215,263,285,310$

Groomsman (70,575), 125

Gunthorpe Beau, 310

Gwynne family, 201, 212 .

Hall, J. M., 299

Halsall Reliance (131,331), 203

Handley, John, 151

Handsome Boy (76,832), 138, 259

Harley, Dr V., 138

Harrison, Captain, 167

Harrison, G., 106, 122, 139, 150, 172,232

Hartnett, W., 172

Harviestoun, 142, 157, 188, 199, 252

Harviestoun Baron (136,965), 146

Harviestoun Norseman, 304

Harviestoun Royal Duke, 243

Hathaway family, 191, 311

Hatton, 112

Hawthorn Blossom family, 133

Hawthorn Champion (99,098), 186, $190,197,206,279$

Hawthorn family (Ingram's), 97

Hay, James, 265

Hay, Petrie, 302

Hean Castle, 264

Hean Clarence (125,971), 102

Hean Conqueror $(131,417), 162$

Heather Bell family, 209

Heatherwick, 112, 113, 114, 138, $172,202,219,223,238,252,294$

Heineman, Mr, 272

Heir of Englishman (24,122), 187, 208, 279, 304
Helen family, 155

Henderson, Wm., 221-225

Hiawatha $(14,705), 211,212$

Highfields, 105

Highland Laddie (112,068), 131

Higson, Howard (Meer Hill), 126

Hill, J., 252

Hill, R. Wylie, 98, 104, 106, 114, $125,128,147,168,199,231,235$, $246,265,277,290,297$

Hill, Sydney, 135

Hillhead (Fort George), 66

Hillhead of Ellon, 97, 182, 262

Hindley Crown (126,037), 143

$\mathrm{His}$ Majesty, 128

Hoarfrost (112,077), 182

Holywood $(95,502), 300$

Hope, Wm., 201

Hoselaw, 203, 281

Hotspur (28,876), 280

Hubback Junior $(59,123), 272$

Hughes Brothers, 294

Hunter, Chas., 103

Hunter, James, 103

Hunter, J. (Glencarse), 103

Hunter, Patrick, 103, 146

Hunter, William C., 103, 127, 145, $172,177,219$

Huntingtower, 109, 271

Huntly, Mrs H., 203

Hutchison, W. E., 300

Inchcoonan, 144

Indispensable $(16,295), 163$

Inglis, G., 238

Inglis, W. (Pirntaton), 209

Ingram, W., 97, 156, 226

Inspector $(72,715), 168$

Inverness " Highland" (1839), 116

Inverness Patrician, 208

Inverquhomery, 149, 188

Invincible, 311

Ivo of Cluny $(99,211), 114,126,128$, 145,231

Jack Tar (115,987), 181

Jackson, W., 259

Jackstown, 122, 142, 216, 264, 310

Jamieson, Dr, 200

Jealousy family, 112, 154, 251, 252

Jenny Lind family, 106, 119, 131 , $199,216,268,276,294$

Jilt family, 105, 109, 110, 144, 148,

$159,160,215,218,303$

Jim Sidey $(99,230), 224,249$ 
Jobbling, Mr, 229

John o' Groat $(13,090), 211,212$, $213,214,271$

Johnston, Col., 107, 173, 209, 235, 263

Jolliffe, C. H., 122, 135, 149, 151, $152,156,157,172,227,245,246$, 259

Jones Brothers, 195-198, 252

Jubilant $(99,240), 136,252,262$

Julian (120,876), 156

Keavil, 304

Keep Smiling (105,835), 162, 199

Keir, 98, 109, 112, 154, 271, 285

Keir Broadsword (116,031), 218

Keir Butterfly, 213

Keir cows, 211

Keir Masher (109,033), 258

Keir Quartermaster $(120,896), 155$, $216,244,253,268$

Keir Raider (102 645), 152

Kellock, C. W., 181

Kemp, James, 120

Kerchesters, 200

Kirklevington family, 255

Kerr Bros. (Lochlane), 104, 126

Kerr, J. Ernest, 188, 204-207, 232, 304,306

Keystone of Cluny (105,856), 217

Kilblean Beauty family, 120, 133, 135,157

Kilblean Stamp (88,978), 126, 210

Killen, 305, 307

Killerby, 212, 248

Kinbeachie Crest, 157

Kinellar, 170, 272

Kinellar Proud Duke, 236

Kinfauns, 125

King Christian of Denmark $(86,316)$, 107,153

King Coral (102,677), 263

King Edward VII., 171

King George, 106, 303

King of Diamonds $(137,377), 114$, 139,165

King of Kessock (38,495), 307

King of Scots, 147

King Victor $(81,394), 110,161$

King's Favcurite $(70,719), 273$

King's Knight $(99,286), 161$

Kingston of Edgcote $(131,776), 102$, 136

Kinkell, 163, 214

Kinnaird, George, Lord, 144
Kinnear, Patrick, 103

Kinpurnie, 155

Kinross, Mr, 167

Kippen, 133

Kirk, Thos., 104, 226

Kirklevington, 111

Kirkwood House, 124, 210, 242, 265

Knight Champion (131,804), 179

Knight Errant (126,349), 101

Knightly Friar (41,773), 272

Knight of Collynie (112,229), 142, $153,190,197,205,217,224,240$, $241,297,311$

Knight of Knowlmere, 229

Knight of Lancaster (131,806), 303

Knight of Rosewood (79,171), 273

Knight of the Rock (24,279), 271

La Concordia Estancia, 96

Lady Anne family, 298

Lady Cathcart, 99

Lady Dorothy family, 97, 98, 111 , $119,120,123,133,134,135,154$, $155,158,162,168,174,176,177$, $181,183,216,218,220,222,226$, $232,242,253,256,258,260,264$, $269,278,284,285$

Lady family, 237

Lady Fragrant family, 170, 171, 229

Ladykirk, 214

Lady Sarah, 257, 258

Lady Sarah family, 106, 115, 116, 205,307

Lancaster Charm, 97

Lancaster family, 97, 107, 119, 148, $156,170,185,186,220,236,276$, $30 \mathrm{~s}$

Lancaster Knight $(116,165), 196$

Lancaster Royal $(109,108), 147,157$, 177

Lancelot $(99,338), 96$

Lancer $(83,846), 174$

Lamington, Lord, 207

Landsman (83,847), 203

Langton, 308

Lathom, Miss, 167, 215

Lauretta family, 139, 303

Lavender family, $101,127,133,135$, $142,143,150,161,173,174,180$, $183,189,195,205,208,220,228$, $233,244,245,253,268,278,297$, 312

Lavender Fancy $(89,047), 260$

Lavender Regent, 245 
Lavender Royal (86,380), 246

Lavender Royal King (116,185), 178

Lavender Star, 246

Lavender Vanguard (105,941), 236

Lavender Victor, 262

Law Bros., 169, 211, 262, 291

Law, C. E., 196

Lawhill, 296, 297

Law, Mrs, 159

Lawson, G., 305

Lawton Schoolmaster, 256

Leader (11,074), 212

Ledingham, J. K., 135, 168, 233

Lee, Joseph, 155

Legars, 111, 138, 201, 228, 229, 283, 292

Leo, 308

Leon, Sir H., 171, 177

Lessendrum, 119, 138

Lethenty, 120, 199

Levanter (89,068), 209

Lexicon, 107

Lex of Cluny $(109,170), 107,172$, $174,180,183,187,217,227$

Lily family, 166, 271, 274

Lily family (Baldowrie), 115, 116

Linksfield, 98, 173, 208, 235

Linksfield Champion (86,401), 152

Linksfield Marius, 107

Linksfield Red Baron (112,982), 121

Lipwood Choice $(126,516), 203$

Little Haddo, 96

Loanhead, 96

Loan of Errol, 144

Lochnagar (74,854), 308

Lochton, 103

Lockhart, Sir S., 274

Lode Star, 192

Lord Advocate, 277

Lord Canning (109,221), 227

Lord Chamberlain (22,129), 285

Lord Dunraven, 159

Lord Elgin (89,117), 216, 258 .

Lord Leith $(95,842), 155$

Lord Lynedoch $(74,900), 122,142$, 152,290

Lord Matadore (106,046), 179, 263

Lord Mayo (77,090), 249

Lord Mayor (132,036), 227

Lord of the Ring (132,041), 289

Lord Provost (65,846), 170, 171

Lord Rector $(83,957), 126$

Lord Remenham $(92,340), 96$

Lord Waterloo (1 16,340), 98

Lordly Archer (70,839), 263
Lothian Alain, 172

Lothian Augustus (116,354), 150, $172,174,228,233,260,269$

Lothian Brigadier, 224

Lothian Buzzard, 128

Lothian Clipper Duke, 106, 172

Lothian Laird (112,374), 97, 182, 262

Lothian Lancer (132,066), 195

Lothian Lex, 161, 197

Lothian Mario (137,713), 107, 173, 209, 235

Lothian Marksman, 145, 173, 192

Lothian Marquis, 173

Lothian Rumbler, 155

Lothian Royal Star (126,644), 285

Lothian Watchman (116,358), 124

Lovat Champion (74,948), 229, 230

Lovat, Lord, 150, 157, 164, 189, 192, $215,294,306,307$

Lovely family, 261

Lovely family (Shethin), 109, 146

Lumsden \& Mackenzie, 110, 127, 299

Lustre family, 106, 156, 161, 174, 216

Luxury (74,958), 188

Luxury family, 107

M'Allister, Wm., 123, 128, 151, 246, 269

Macdonald, D., 167

M'Dougall, D. (Dall), 246

M'Tadyen, Sir J., 279

M'Garva, G. R., 114

Macgillivray, Capt. John, 99, 105, $120,154,178,183,184,187,190$, 226, 283

Macgregor, A., 220

M'Intosh, Thos., 100-102, 176, 177, $201,202,220,229,252,253,258$, 265

M'Intyre, P. B., 97, 187

Mackail, J. W., 140

Mackay, H. M. S., 300

M'Kessock, Mr, 311

Mackie, John, 224

Mackie, Wm. S., 146, 147

M'Laren, J. T., 171, 175, 261

M'Laren, J. T., jun., 280

M'Laren, W. F., 249

Maclean, Major, 205, 242

Maclennan, D., 128, 164, 165, 241,

$250,261,262,274,275,287,299$

Macnab, A., 141 
Maconochie, A. W., 99, 159, 165

Macrae, H. R. (of Clunes), 100

Macrae, Lieut., 157

M'William, Jas., 156, 188, 206, 302, 309,310

M'William, R. S., 99

Macebearer $(126,693), 139,165$

Maden, Sir J. H., 227

Magenta $(20,253), 214$

Magnetic Star (126,714), 106

Mahogany (137,789), 203

Mains of Murthly, 112, 215, 261, 264,303

Mains of Sanquhar, 149, 183, 186, $197,252,262,264,277,291$

Major Windsor (34,739), 293

Malcolm, W. M., 310

Malcolm, W. T., 260, 266, 277, 278, 308-312

Manchuria $(92,428), 119$

Man of War $(65,886), 273$

Manson, J. B., 191

Mantalini family, 248

Manuel Censor, 231

Manvers, Earl, 110, 122, 131

Marchioness family, 163, 215

Marchioness family (Strowan), 286, 287, 289

March On (89,231), 110

Marengo, 262

Maria family, 199

Marigold family, 98, 112, 120, 127, $138,139,145,173,174,176,177$, $191,192,215,220,229,230,238$, $241,242,258,300$

Mario, 277

Mario 2nd (59,439), 268, 277, 286

Marksman $(70,945), 309,310$

Marksman, 263

Marmion (100,933), 267

Marquis $(56,147), 292$

Marquis $(84,061), 114,149,178,186$, $193,194,209,221,256,301$

Marquis of Worcester, 309

Marr, John, 105, 139, 180, 303

Marr, W. S., 208, 238, 263, 294.

Marshall, A. J., 123,.131, 132, 147$153,156,173,183,188,199,205-$ $207,209,210,239,253,303$

Marshall, H. B., 244, 267-270

Marshall, M., 147

Martial Hero (79,383), 308

Marvel family (Lochside), 280

Mary o' Argyll family, 107, 146, 176, $178,283,285$
Master Archer (70,962), 309

Master Archer (73,007), 238

Master Cowslip $(31,862), 168$

Master Henry $(31,868), 168$

Master Millicent $(84,084), 155,174$, 192,215

Master of the Ceremonies, 311

Master Pye 'nd (116,503), 100

Masterstroke $(126,820), 158$

Mastodon (102,989), 235

Matadore family, 238, 263

Match Him $(53,296), 163$

Matchmaker $(86,590), 152$

Matilda family, $167,168,208,210$, 234,236

Maude family, 139, 158, 276

Max of Cluny $(112,487), 129,143$, $162,190,216,241,247,249,301$

Maxtone, Jas., 270, 271

Maxwell, Sir W. S., 211-214

Mayflower family, 113, 114, 134, $138,139,172,174,176,210,252$, 294

Mayor of Brussels, 179

Meadow Queen family, 310

Meg Mirrilies family, 98, 104, 185, $222,235,300$

Meikle, R., 130-132

Meiklem Bros., 312

Meiklem, W., 124

Mendel $(103,025), 149$

Menzies, R., 265

Mercury $(77,253), 134$

Mercury's Farewell $(99,609), 265,266$

Merlin (54,715), 109, 199

Merranio $(99,619), 310$

Merry Archer (67,477), 135, 176, 216

Merry Challenger 2nd $(99,622), 100$

Merry Courtier $(116,440), 210$

Merry Matadore (112,530), 156

Merry Stamp $(99,629), 240,304$

Merry Victor $(116,563), 124,147$, $159,177,267,304$

Merthyr, Lord, 128

Mertoun, 96, 137, 200, 201, 228, 248, 297

Michie, G., 21, 302

Middlefield House, 299

Middleton of Troup, 97, 226

Middleton, 141

Midshipman (99,643), 203

Miller, F., 287

Miller, Sir James, 228, 229

Miller, Lady, 230

Miller, W. S., 121 
Millhills, 104, 120, 122, 126, 165, $176,178,192,199,206,220,221$, $247,251,283,290,296,297$

Millhills Comet, 241

Millhills Rothes King, 99, 105, 269

Millicent Chief $(96,096), 155,171$, $172,174,256,263,264$

Mill of Wartle, 223

Millom Count (138,924), 292

Mills, Philo L., 312

Milne Bros., 201

Milne, James, 135

Milne, Miss, 201, 281, 292

Milne, N. (Dryhope), 280

Milne, N. (Faldonside), 212, 290

Milton of Ardlethen, 145, 168

Milton of Luncarty, 177

Mina family, 170, 171, 257, 258

Minmore, 119, 215

Minmore Quilter (109,417), 155, 231

Minotaur of Dalmeny, 171

Miriam family, 286, 288

Miriam family (Newton), 218

Missie family, 128, 152, 158, 161, $170,195,238$

Miss Ramsden family, 98, 104, 105 , $126,127,129,133,146,148,156$, $157,159,161,174,181,183,199$, $201,214,219,220,222,230,235$, $257,272,275,276,284,285,290$, $297,303,312$

Mitchell, A., 248

Mitchell, S., 123, 127, 132-137, 155, $220,232,244,265$

Monarch (4495), 115

Monarch (138,037), 156

Monarch's Fancy (89,355), 229, 230

Moness, 154, 186

Monkshood (138,049), 139

Monorgan, 103

Montrave, 112, 131, 149, 216, 219, $261,273,277,289,300$

Montrave Bloom $(81,740), 110,192$, 289

Moonlight Yet $(103,125), 250$

Moor of Muckart, 247

Moore, D. H., 155, 216, 231

Moore, Parkin-, 162, 182, 186, 199

Moray, Earl of, 104, 150, 180, 183 , $205,218,235,269,279$

Moresby Pilot, 255

Morning Star (109,463), 179

Morrison, A., 277

Morrison, I. K., 145, 188

Morrison, James, 112
Moss Rose family (Dryhope), 290, 291

Mowbray, J., 247

Mowbray, J. J., 124, 147, 150, 154, 227, 232, 247, 254, 309

Mountain Prince (61,343), 280

Mounteagle, 177, 226

Muirton of Barra, 172, 235

Munlochy, 108

Munro Bros., 243-247, 268

Munro, Col. Chas., 100, 112, 118, $138,139,144,154,159,169,177$, $198,243,261,267,272,304$

Munro, J., 280

Murie Edge, 144

Murison, G., 168, 246

Murray, Mr (Old Manse), 106

Murray, James, 107, 123, 124, 125

Murray, John, 135

Murray, Major, 107, 123, 124, 125

Murray, W. (Kilcoy), 126

Myrtle, 243

Myrtle Archer, 216

Myrtle family, 100, 102, 124, 138, $139,140,146,157,169,176,179$, $195,196,197,199,278,283,285$, 309

Myreton (84,199), 191

Mysie family (Keir), 139, 145, 163, $314,315,396$

Mysie family (Shethin), 99, 100, 102, $105,118,119,120,134,138,159$, $167,168,176,177,201,202,220$, $229,252,253,258,265$

Naemoor, 154, 195, 219, 227, 232, $233,260,312$

Naemoor Comet, 143

Napier, C., 132, 144, 182

Napier, W., 230, 258, 291

Nelson \& Sons, 274

Nether Dallachy, 145, 149, 230, 258, 291

Nestor of Cluny (116,733), 254

Netherley, 260

Nettlefold, Mr, 160

New Aberdour, 243

Newbie, 159, 229

New Year's Gift, 151

Newbiggin, 141, 143

Newbus Grange, 157, 277

Newmore, 159, 238

Newton, 100, 112, 119, 131, 134, $142,164,191,199,209,227,233$, $235,238,251,258,267,273,276$, $277,278,286$ 
Newton Cossack, 285

Newton Count $(132,490), 144,197$, 252

Newton Crystal $(92,658), 164,199$, 200, 277, 279

Newton Grand Duke $(138,201), 273$

Newton Renown (121,779), 279

Newton Royal Beau, 285

Newton Star $(103,183), 215$

Newton Stone $(75,129), 194$

Newton of Barra, 253

Nichol, A. F., 202

Nickell, J. T., 142

Nigel of Cluny $(116,747), 111,113$, $146,147,208$

Nimrod (75, 135), 289

Nisbet, J., 201

Niven, Wm., 144

Nonakiln, 168

Nonpareil Champion (112,667), 255

Nonpareil Clipper, 232

Nonpareil Courtier $(79,488), 152$, 195,297

Nonpareil Crown $(96,221), 159,160$, 162

Nonpareil Duke, 206

Nonpareil family, $79,121,122,128$, $133,134,142,143,148,156,158$, $170,173,174,181,183,189,205$, $217,219,227,232,238,302,304$

Nonpareil Gift $(103,196), 283$

Nonpareil Star (121,793), 97

Norman of Cluny $(116,778), 144$

North Loirston, 98, 102, 128, 220, $227,233,244,285$

Northbrook, Earl of, 165

Northumberland, Duke of, 229

Notlaw Nelson $(127,166), 235$

Ochils, 133

Ogilby, Col., 107, 200

Old Craig, 210, 215

Old Manse, 142

Oliver, Captain, 203

Oliver, Colonel James, 138

Oliver, R. (of Lochside), 138

Oliverburn, 125, 126, 129, 222

O'Malley, Thos., 149

Orange Blossom family, 100, 101, $102,106,123,124,127,128,129$, $136,142,148,149,156,158,161$, $181,182,183,195,196,199,202$, $233,242,245,264,277,285,306$

Orangeman $(84,263), 210$

Orchardmains, 137,280
Orion (84,265), 229

Orthodox, 271

Orton (79,509), 223

Osberton, 286

Ossian of Cluny (121,904), 156

Oswald, Gordon, 96, 100, 127, 161, 176,235

Otterburn, 201, 281, 292

Palmallet, 148

Pereyra, L., 273

Paterson, J. J., 199

Paterson, J. W. J., 292-294

Paton, Mr, 119

Paul Pry, 115

Pauline family, 238, 279, 296

Pauline family (Newton), 178, 179, 199

Peach Blossom family, 294

Pearl Caster (132,650), 296

Pearlfinder (116,911), 179

Pearl King, 151

Pearl King 2nd (89,531), 129

Peel I. (Clitheroe), 213

Peerless Prince, 138

Pellipar Jehu, 107

Pellipar Judge, 201

Pellipar Iris, 153

Perfect Motion (112,780), 294

Peterkin Bros., 151, 189, 196, 219, 262, 263

Petty, 252

Phantassie Flower family, 179

Phingask, 112, 222, 277, 299, 308

Pillar Stone $(84,311), 100,118$, 312

Piper, James, 105, 295-298

Pirriesmill, 109, 161, 180, 185, 188, $210,227,245,251,264,299,303$, 309

Pitcur, 109, 110, 215, 238, 263, 309

Pittodrie, 306

Pleuro at Keir, 212-213

Polmaise, 112, 124, 144, 155, 174, 196,245

Polmaise Handsome Prince $(96,423)$, 131,261

Polmaise Marengo, 262

Polmaise Nimrod, 263

Polmaise Osian, 261

Polmaise Proud Baron, 261

Polmaise Quartermaster, 264

Polmaise Quiver (127,324), 106

Polmaise Royal Baron $(132,741), 202$, 262 
Polmaise Star $(138,478), 216$

Polmaise Top Knot, 263

Polwarth, Lord, 248

Portland, Duke of, 101

Postmaster (144,482), 279, 308

Potter, Mr, 310

Powburn, 163

Powis, Earl of, 309

Premier (132,759), 113

President of the Mint (109,670), 99 , $107,178,240,267$

Presson, 201

Preston Grange, 179

Pride Family, 163, 270

Pride of Avon (86,878), 139, 151, $178,210,218,240,253,311$

Pride of Edgcote $(109,675), 128$

Pride of Freedom $(73,241), 203$

Pride of Livet $(109,678), 222,232$, 273

Pride of Millhills, 192, 241

Pride of Polmaise (122,082), 196, 263

Pride of Rosewood (144,524), 120

Pride of Tees $(96,474), 153$

Pride of the Goldies $(100,006), 210$

Pride of the Herd $(100,007), 146$, 197

Pride of the Isles, 122, 134, 181

Pride's Farewell $(84,350), 160$

Primrose Archer (84,311), 100, 118, 312

Primrose Earl (89,641), 122

Primrose family, 163, 270

Primrose Knight (84,357), 149, 151

Primrose Monarch (106,554), 199

Primrose Pride $(79,605), 151$

Primrose Prince (127,380), 244, 245

Primrose Star (106,555), 144, 242

Prince Bismarck $(66,041), 201$

Prince Butterfly (132,797), 256

Prince Charlie $(51,875), 272$

Prince Charming $(50,197), 280$

Prince Edgar $(100,036), 173,180$, $192,193,194$

Prince Favourite $(106,546), 146$, 206

Prince Fortinbras (79,618), 110

Prince Imperial $(127,411), 227$

Prince Nonpareil (92,898), 139

Prince of Ceremonies (92,903), 277

Prince of Fashion $(64,587), 132,150$, 224

Prince of Lancaster (92,907), 134

Prince of Masters (73,305), 273
Prince of Orange $(132,831), 176,266$

Prince of Sanquhar $(71,251), 134$

Prince of the Blood $(96,532), 156$, 278

Prince Palatine (117,071), 120, 220, 238

Prince William (59,706), 281

Princely Favourite (112,873), 164

Princess Beatrice family, 290, 291

Princess family (Apperly), 140

Princess family (Faldonside), 281, 290,291

Princess Royal family, 98, 99, 102 , $127,128,133,136,142,143,148$, $149,150,151,154,157,158,172$, $174,177,181,182,183,204,218$, $219,227,232,238,239,253,269$, 276, 278, 297, 300

Prior of Dalmeny $(69,328), 229$

Prognosticator $(66,092), 261$

Proud Barrister $(117,100), 97$

Proud Beau 3rd (106,627), 128, 265

Proud Champion $(100,096), 101,128$, 264

Proud Champion (109,765), 155, 244

Proud Chief, 168

Proud Duke (1I7,109), 169

Proud Edward, 134

Proud Emblem (100,099), 178, 189

Proud Emperor (112,912), 245

Proud Favourite $(84,420), 126,164$, 206, 239, 283, 290

Proud Jubilent, 262

Proud Marcus (112,917), 201

Proud Massa (109,776), 106, 262, 264

Proud Messenger (138,641), 226

Proud Monarch (92,961), 134, 136, 223, 268, 306

Proud Napoleon (122,231), 215

Proud Nonpareil (122,232), 182, 210

Proud Victor (103,447), 256

Proud Warrior $(106,653), 114,123$, $145,185,188,189,205,218$

Proud Waterloo, 210

Pye family (Garne), 100, 102

Quartermaster (132,925), 158, 278

Queen of Rothes family, 133, 135, $136,154,158,174,182,183,189$, $195,196,202,203,215,219,224$, $238,240,241,242,253,254,258$, $260,264,268$

Queen of Spey family, 112

Question Mark (109,803), 154, 250 
Rachan, 119, 244

Rachan Litigant, 268

Rachel family, 114, 118, 154, 186, 187, 190, 255, 256, 279, 301

Radiance, 161

Radnor of Cluny, 174

Ramsden Rover, 257

Ramsden Rufus $(138,717), 104,111$, 156,199

Ravensworth (7400), 280

Record of Sanquhar, 261, 264

Red Baron (112,982), 184, 263

Red Clipper $(96,648), 300$

Red Emperor $(87,026), 176$

Red Ensign $(93,035), 96$

Redgauntlet $(117,238), 144$

Redgorton, 222, 232

Redgorton Augustus (112,995), 222

Redgorton Censor 2nd (127,611), 233

Redgorton Cruiser, 274

Redgorton Dandy, 264, 275

Redgorton Dictator (133,019), 264

Redgorton Duke (133,022), 275

Redgorton Earl $(244,805), 99$

Redgorton Emissary, 275

Redgorton Ensign, 275

Redgorton Envoy $(144,809), 169$

Redgorton Epicure (133,013), 233

Redgorton Expert (144,810), 226

Red Granite $(106,726), 146$

Red Knight (24,916), 280

Red Knight (133,028), 228

Reformer (89,801), 169

Regal Crown $(117,292), 265$

Regal Star (87,061), 258

Regent (106,754), 206, 233

Regina family, 164, 303

Reginald (64,654), 109

Reid, A. H., 182, 262

Reid, A. M. (Currochs), 297

Reid, J. L., 191

Reid, N., 308

Rettie, 185

Revelry family, 257, 258, 309

Reynard, Jas. N., 230-234

Rhynie, 235, 242, 260

Richmond, Duke of, 112

Riddell Bros., 203-204, 281

Ringleader $(136,651), 150$

Ringleader, 171

Ringmaster $(109,913), 118,220$

Ritchie, H. O., 260

R.N.D. $(93,110), 209$

Roan Benson (100,301), 203

Roan Conqueror $(84,519), 151,152$
Roan Gauntlet $(35,284), 122,161$, 181

Roan Lady family, $133,151,152$, $158,161,162,206,229,239,250$, 258

Roan Rosebud, 221

Robertson, A., 112, 118, 154, 186, 193, 237, 249

Robertson, A. (Polmaise), 261

Robertson, J. \& D., 154, 155, 242, 268

"Robertson, Laird," 222

Rodger, Jas., 214, 216

Romping Girl, 248

Ronald, 152

Rosalie family (Duthie's), 120

Rosario, 181

Rosario, K., 181

Roscommon $(93,173), 122$

Rose family (Buccleuch), 222

Rose family (Cumledge), 280, 281

Rose family (Northumberland), 278

Rose, Messrs, 220

Rose, Wm., 118-120, 231, 233

Rosebery, Earl of, 107, 161, 170, $192,224,241,287,298$

Rosebud family (Crofton and Northumberland), 134, 167, 168

Rosebud family (Kinellar), 98, 135, $138,139,148,149,153,154,158$, $181,182,183,189,191,193,199$, $219,221,226,238,242,269,296$

Rosehaugh, 111, 183, 223, 262

Rosehaugh $(127,823), 296$

Rosemary Beau $(122,528), 265,266$

Rosemary family, $127,155,156$, $167,168,189,234,235,283,284$, 285,299

Rosemere (122,530), 223

Rosemount, 106, 114, 116, 117

Rosemount (109,965), 265

Rosewood family, 106, 119, 120, 133, $148,149,160,168,176,177,181$, $182,188,205,220,232,238,249$, 252,312

Rosewood Crown, 160

Rosicrucian (75,483), 192

Rothes, 219

Rothes King, 203

Rothiebrisbane, 146, 155, 161, 196, $199,219,243,278,303$

Rothschild, Lady Alice de, 193

Rothschild, Lord, 287

Rothwell, R., 288

Rouge Royal, 179, 199, 200, 202 
Royal Alfred (66,176), 168, 268, 269

Royal Archer (71,943), 223

Royal Banner (87,152), 110, 196

Royal Beau, 155, 156, 157

Royal Beaufort $(89,803), 134$

Royal Bounty $(89,907), 272,273$

Royal Butterfly 11th $(20,719), 211$, 212

Royal Charter (84,585), 220, 258, 299

Royal Clarion (117,457), 220

Royal Clarion (139,028), 243

Royal Clipper, 132

Royal Crest $(106,894), 182$

Royal Crest $(113,146), 273$

Royal Crown (84,598), 134, 162, 181, 191, 194, 206, 266

Royal Crown $(117,292), 120$

Royal Cup, 193

Royal Defender, 233

Royal Diamond $(84,600), 150$

Royal Duke $(96,890), 110$

Royal Duke of Gloucester $(29,864)$, 134

Royal Eclipse $(87,179), 149,152$, 192,239

Royal Edward (82,153), 133, 162, $195,224,229,230$

Royal Emblem (82,154), 152

Royal Gem, 147

Royal Goldie (103,704), 119

Royal Guard (113,165), 280

Royal Guard $(127,907), 306$

Royal Harry $(27,367), 166$

Royal Harold $(64,736), 248$

Royal Hope $(139,079), 203$

Royal James $(54,972), 122$

Royal Jester $(127,669), 160$

Royal King Goldie $(117,294), 160$, 162

Royal Lamorby $(59,830), 272$

Royal Leader (103,737), 97, 105, $119,120,174,180,223,233,242$, 268,304

Royal Leader (113,173), Horn's, 119

Royal Luxury $(106,919), 183$

Royal Marksman, 113

Royal Marksman $(117,494), 310$

Royal Master (110,019), 215

Royal Northern, 99

Royal Ordo, 193

Royal Pride (71,489), 126, 135, 169, 272

Royal Pride $(106,935), 177$

Royal Prince $(93,268), 96$
Royal Prince $(113,183), 231$

Royal Reign (103,747), 159, 162

Royal Star $(71,502), 105,134$, 237

Royal Vanguard (103,767), 119

Roysterer, 146

Rubicon, 181, 183, 194

Ruby family, 195, 196, 200, 262

Ruby family (Dunglass), 110, 151

Rubyhill family, 209, 279

Ruddington Hall, 262, 312

Ruddington King Edward, 262

Ruddy Star $(73,555), 277$

Rufus $(117,567), 154$

Russell, G., 112

Sailor Prince $(93,318), 203$

St Clair $(79,884), 216$

Saltoun, 128, 156, 268

Salvin, Mr, 96

Saphock, 96, 97, 113, 142, 165, 172, $178,184,185,188,189,210,215$, $218,243,285,303,310$

Saphock Diamond Star $(98,593), 152$

Sandringham, 170

Sanquhar, 238

Sanquhar Eclipse $(117,605), 197$

Sanquhar Grand Courtier $(139,193)$, $157,183,190,279$

Sanquhar Grand Gallant $(133,421)$, 206, 304

Sanquhar Knight Marshal $(133,424)$, 98,226

Sanquhar Searchlight, 180

Sanquhar Union Jack $(122,751), 98$

Saracen $(133,429), 292$

Satellite $(90,044), 203$

Schoolmaster $(39,068), 272$

Schoolmaster $(110,095), 160,162$, $182,199,257$

Scotch Monarch $(84,718), 169$

Scotch Thistle $(73,584), 145,188$, 196, 197, 211

Scotland's Heir $(75,593), 229$

Scott, Jas., 280, 281

Scott, J. G., 155, 161, 180, 194

Scott, W. M., 144, 169

Scottish Archer $(59,893), 136,152$, $194,216,228,229,297,308$

Scottish Chieftain $(97,047) 118$

Scottish Courtier $(90,063), 192,195$

Scottish Crest $(113,259), 145$

Scottish Crown $(79,915), 98$

Scottish Fancy (75,601), 191, 195, $228,229,240,311$ 


\section{INDEX}

Scottish Farmer $(103,837), 240$

Soottish Favourite $(84,72$ '), 149

Scottish Gift $(110,102), 112,113$, 114

Scottish Monarch $(75,598), 134$

Scottish Regent $(93,373), 134,246$

Scrimgeour, J., 185, 186, 189

Scurfield, Mrs, 278

Sea King $(61,769), 150$

Secret family, 101, 105, 121, 124, $127,136,145,148,150,161,162$, $176,177,180,181,183,189,191$, $194,198,199,205,223,238,257$, $264,265,278,285,306,312$

Secret Signal $(145,342), 266$

Shaddock $(128,126), 106$

Sharp, Messrs, 219

Sharpshooter $(90,093), 259$

Shenley, Colonel, 184

Shepherd, Jos., 193, 244

Shethin, 261

Shiel Bros., 200-203

Shields, G. B., 97, 146, 179-184, $187,190,194,225$

Shields, Jas., 225-228

Shuttlefeather family, 119, 156, 161

Sidey, Jas., 172, 244, 274

Sigmund (67,905), 159

Silver Arrow, 292

Silver Crest $(77,865), 134$

Silver Crown $(117,733), 208$

Silver Mint, 172

Silver Plate $(75,633), 121$

Simmers, F., 142, 161, 185

Sinclair, G., 175

Sinclair, Sir R., 282

Sir Archibald Christon (75,639), 149

Sir George $(60,593), 159$

Sir Grimston Studley 2nd $(75,668)$, 249

Sir Randolph $(113,368), 146$

Sir Robert, 115

Sir Walter $(45,627), 272,309$

Sisterpath, 201

Sittyton, 109, 122, 163, 180, 181, $213,215,220,228,245,246,264$, $269,271,272,277$

Sittyton Choice $(84,822), 160$

Sittyton Seal $(64,866), 170,229$

Sittyton Style $(110,212), 231,232$, 233

Sittyton Type $(28,244), 202$

Sittyton Yet $(133,632), 98$

Sivewright, Sir Jas., 104, 106, 159, 301.304
Smiley, Sir H., 109, 142, 205, 306

Smith, Leslie, 104, 107, 187, 194

Smith, Mr (Balmain), 167

Smith, Mr (Pittodrie), 193

Smith, Mrs, 306

Smith, Wm., 161

Snow family (Baldowrie), 115, 116

Snowflake $(18,888), 280$

Snowfly family, 222

Solid Silver $(87,418), 224$

Son of Petteril (4685), 229

Sourhope, 200, 202

Southwick, 214

Sovereign $(61,841), 150$

Spency Speculator $(133,715), 257$

Spicy Beau $(139,407), 235$

Spicy Gift $(110,737), 114$

Spicy King $(75,717), 122$

Spicy Monarch (73,701), 191, 229

Spicy Robin $(69,038), 239,286,289$

Sportsman $(75,719), 289$

Spotsmains, 137, 138, 280

Sprightly family, 201

Stage Pirate $(114,320), 210$

Stainton, 227, 228

Stanhope $(66,380), 181$

Stanley, 115

Stannington $(60,012), 293$

Staples, Miss, 300

Star of Atholl $(77,962), 169$

Star of Dawn (71,681), 286, 287, 289

Star of Dawn $(117,858), 232,233$, 250,252

Star of Edzell $(82,388), 308$

Star of Morning $(58,189), 105,132$, $227,240,249,252,255,268,277$, 286

Star of Scotland $(90,232), 161$

Stephen Fitz Lavender $(73,732), 148$

Stewart, A., 290

Sterling Character (97,289), 294

Stewart, D., 164, 166, 171, 191, 192, $193,219,232,236-42,266$

Stewart Jamieson, 167

Stewart, Mark, 214

Still, A. M., 134

Stirling, A., 211

Stirling, Brig.-Gen., 155, 214-217, 218

Stirling, Major Graham, 126, 129, $170,218,222,253,268,285-290$

Stirling, H. B., 178

Stoneytown, 185, 287, 302, 309

Stoneytown, Baron $(128,347), 292$

Stoneytown Challenger, 99 
Stormont, 117

Storm Signal (110,293), 192, 194, 195

Stott, Mr, 163, 311

Stow-on-the-Wold, 165

Stracathro $(100,776), 258$

Strathmore $(90,264), 117,200$

Strathtay Major $(123,152), 178$

Strawberry family, 216

Strawberry family (Blebo), 248

Strowan $(107,206), 106,110,124$, 127, 161, 192, 269, 306

Strowan Archduke, 287

Strowan Butterfly 24th (104,110), $110,113,156,159,160,162,182$, 256,288

Strowan Butterfly 28th (117,922), 176

Strowan Champion, 289

Strowan Clarion (110,333), 273

Strowan Clarionet, 289

Strowan Claverhouse (110,334), 218, 289

Strowan Duke 3rd (104,114), 209

Strovan Ensign, 287

Strowan Marquis $(63,417), 170,287$, 298

Strowan Marquis 13th, 288, 289

Strowan Marquis 14th, 263

Strowan Regent (97,347), 287, 289

Strowan Royal Duke, 287

Sunset family (Legars), 111

Sunshine family, 191

Sunstar (117,944), 106, 144

Sweet Maid family, 209

Swinnie, 138

Swordsman $(69,689), 273$

Tarty Favourite, 202, 280

Taylor, Mr (Uras), 167

Tempest, Sir C. H., 281

Terrona, 199

Test Act $(128,475), 284$

The Abbot $(60,229), 309$

The Baron (5420), 115

The Grange, 105

The Langcot, 256

The Leader $(66,428), 310$

The Pacha, 193

Thomson, J., 290

Thomson, S., 228

Throsk, 98, 113, 185, 259, 260, 269

Throsk Broadhooks, 299

Throsk Broadhooks 24th $(133,930)$, 157

Throsk Broadhooks 26th (133,930), 283, 284, 285
Throsk Masterpiece $(133,934), 220$, 267

Throsk Monarch (123,265), 98

Tilbouries, 160, 161, 299, 303

Tillygreig, 156, 160, 189, 203, 246

Tirinie, 265

Tom Bowling $(97,441), 118,178$, 222, 250, 279

Tomich, 186

Torr, W., 212

Torrance, G., 201

Towie Barclay, 284

Towie Barclay Landsman $(139,769)$, 236

Towie Barclay Statesman (133,980), 208

Trotter, W. R., 148

Troutbeck, Mr, 212

Tulliallan, 103, 104, 124, 144, 147, $155,159,177,189,231,269$

Turner, W. P., 168

Turton, E. R., 278

Tweedside, 137

Undine family (Lovat), 113, 216, 255,256

Uppermill, 109, 110, 113, 118, 119, $120,124,127,138,139,149,150$, $151,152,158,159,160,163,164$, $170,182,188,189,196,197,199$, $205,208,220,223,228,229,238$, $239,246,249,253,256,272,273$, $278,286,294,303,304$

Uppermill Knight (134,052), 284

Ury, 115, 193

Ury Archer (84,945), 308

Ury Lass family, 170

Vain Beau (71,854), 309

Vanguard (97,521), 228

Vanity, 271

Veitch, G., 173, 180, 191

Velox of Naemoor, 251

Velvet (68,029), 292

Venus family, 133, 233

Veronica family, 170, 171

Vice Chancellor $(56,681), 150$

Viceroy 2nd $(82,526), 15 \mathrm{I}$

Victor Chief $(82,532), 249$

Victor Royal (97,538), 142

Victor of Sittyton $(80,171), 229$

Victoria family, 127, 129, 205, 246

Victorious $(73,822), 310$

Viking of Naemoor, 252

Village Bard (87,630), 161 
Village Maid family, 154

Vinedresser (101,000), 231

Vine family, 133, 304

Violet family, 128, 133, 145, 174, $180,181,182,183,205,232,277$

Violet Royal $(90,424), 139,280$

Violet's Fame $(78,078), 121$

Violet's Pride $(93,761), 291,292$

Violet's Victory $(85,001), 184,277$

Violette family, 237

Vulcan of Naemoor $(134,187), 179$

Wales, Prince of, 277

Walker, George, 156, 160, 189, 246

Wallace, F. L., 175, 184, 273

Wallace of Naemoor, 146

Wanderer $(60,138), 159,239,247$

Waresley, 250

Waresley Crystal Star (101,039), 250

Warlaby, 228, 248

Warrior of Naemoor, 252

Watchman, 132

Watchman (71,828), 231

Watchword, 132, 262

Waterloo, 257, 258, 259, 262, 305, 307

Waterloo family, $96,112,126,129$, $144,145,161,171,174,210,218$, $231,238,296,303$

Waterybutts, 103, 146

Watson, A., 167

Watson, Hugh, 47

Watson, John, 124, 147, 210, 242, 265,266

Wave family, 96

Wave King $(48,916), 311$

Waverley $(68,072), 126,149,162$, 182,210

Webster, J. D., 158, 233, 310

Welcome Guest $(75,875), 307$

Welcome Stamp $(78,135), 308$

Wemyss, Earl of, 225

West Fingask, 124, 127, 142, 161, 214, 264, 306

West Inchmichael, 145

Wester Lovat, 173, 182, 213

Westerton, 100, 138, 169, 185, 309
Westside, 109, 205, 258, 265

Westside Clipper $(101,095), 258$

White Archer $(78,144), 273$

White Emperor (101,104), 122

White Knight (12,848), 123, 150,151, 152,199

Whitehouse, 256

Whiteside, 142, 185, 189

Whitrig Hill, 140, 179

Whittingehame, 97, 127, 147, 182, 219,284

Whittome, Mr, 98

Wild Duchess family, 144, 167, 168

Wild Eyes family, 297

Wilkins Micawber (56,768), 306

Wilkinson, F. B., 241

William of Orange $(50,694), 125,134$, $150,188,208,230,239,240,253$, $256,286,297$

Williams, H., 149

Williamson, D. D., 97, 182, 210

Williamson, Col. D. R., 165

Willis, J. Deane, 122, 148, 151, 181, 214,245

Wilson, J. (Cumledge), 280

Wilson, J. C., 302

Wilson, Peter (Lawhill), 104, 218 221

Wilson, $\mathrm{Mr}$ (of Davidston), 146

Wilson, Sir Jacob, 249

Wimple family, 112, 113, 145, 174, 218

Windmill Standard, 227

Windsor, 127, 167, 181, 306

Windsor Augustus, 128

Windsor Knight, 132

Wood, P., 299

Woodend, 168, 223, 224, 258, 268

Wrench, Right Hon. F., 121, 184, 263

Wyberg, A., 256

Wylam-on-Tyne, 228

Wyllie, Scott, 177, 242, 243

Young, A., 211

Young Bros. (Cadboll), 97, 264, 275

Young, John, 160, 299 

THIS BOOK IS DUE ON THE LAST DATE STAMPED BELOW

BOOKS REQUESTED BY ANOTHER BORROWER ARE SUBJECT TO RECALL AFTER ONE WEEK. RENEWED BOOKS ARE SUBJECT TO IMMEDIATE RECALL

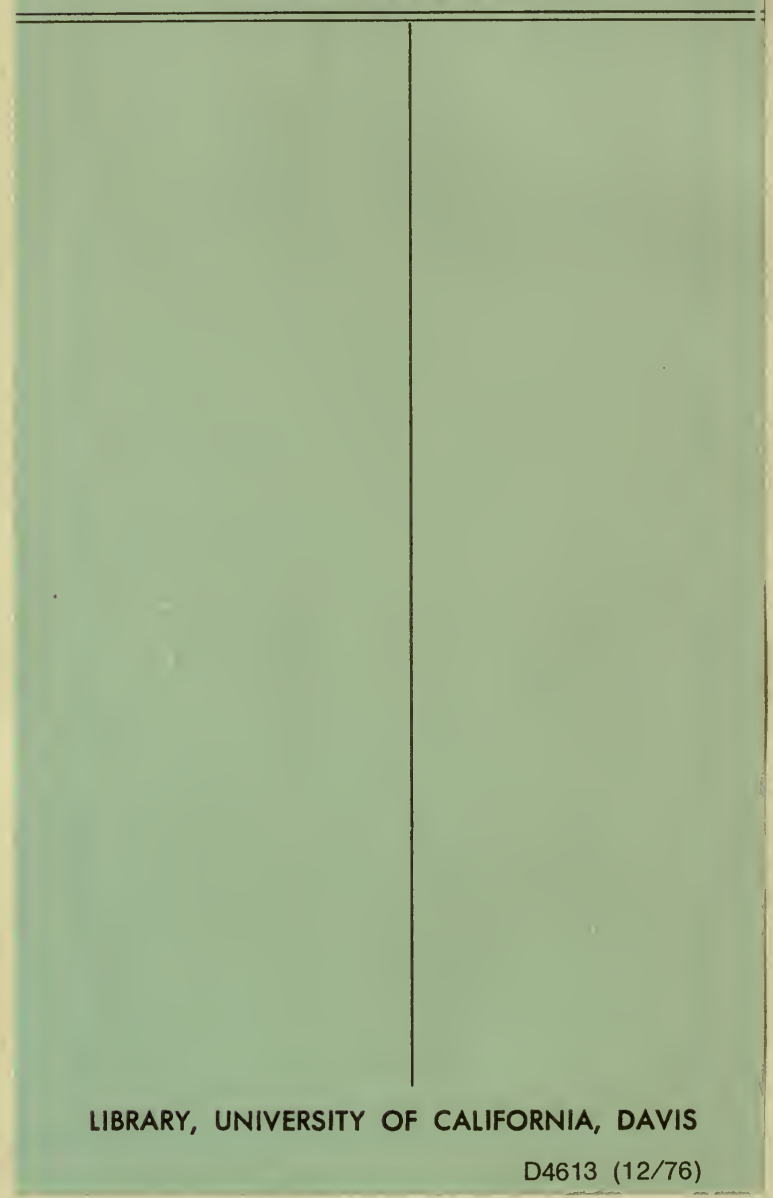




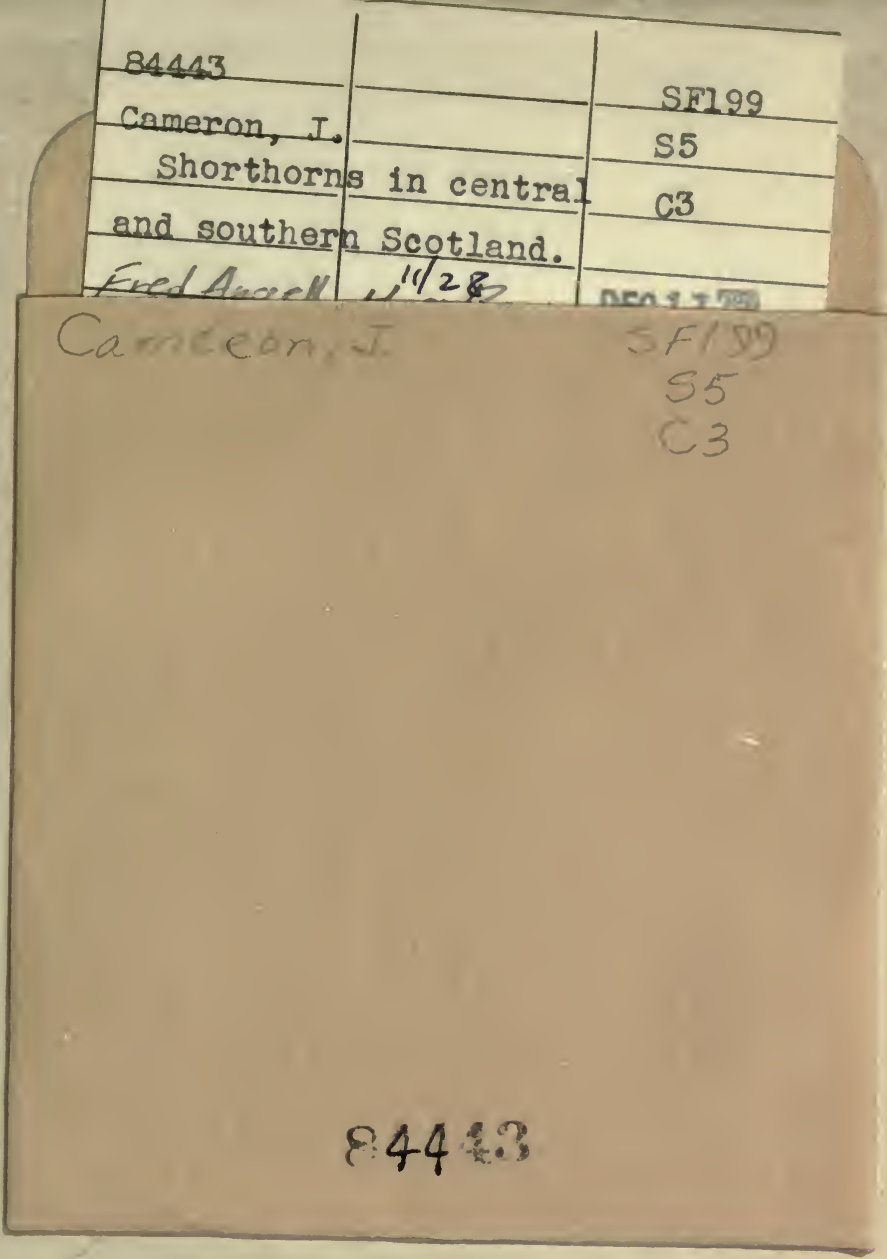


(2): 8.

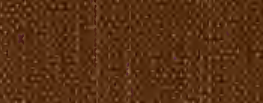
S.

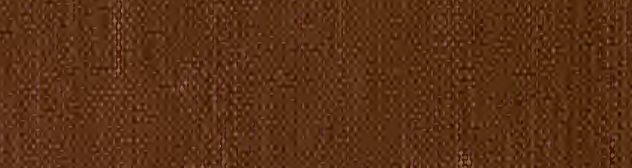

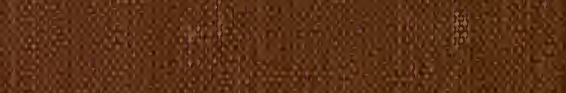

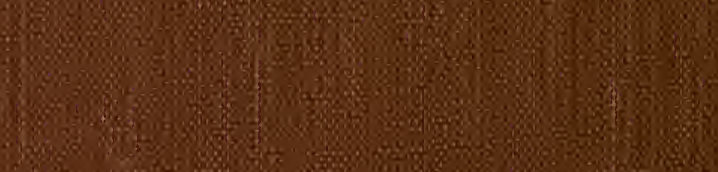

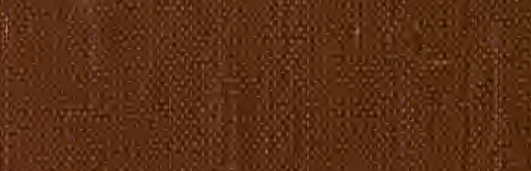
40

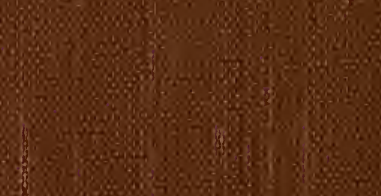

